\title{
Lake Diatoms as Indicators of Late Holocene Climate Variability in the Boreal Region of the Northwest Territories, Canada
}

\author{
by
}

April Sue Dalton

\begin{abstract}
A thesis submitted to the Faculty of Graduate and Postdoctoral Affairs in partial
\end{abstract} fulfillment of the requirement for the degree of

\author{
Master of Science \\ in \\ Earth Sciences \\ Carleton University \\ Ottawa, Ontario
}

(C) 2013

April Sue Dalton 


\begin{abstract}
This thesis is comprised of two manuscripts that focus on diatom ecological change through a late Holocene $\sim 3300$ year record from a $116.2 \mathrm{~cm}$ freeze core obtained from Danny's Lake, Northwest Territories, Canada. The diatom results indicate that climate in this region has been relatively stable through the past $3330 \mathrm{cal}$. yr BP, although three distinct diatom assemblages are recognized. Time-series analysis was also carried out on select diatom species from the Danny's lake sediment core. We correlate the c. 89 and c. 145 year cycles with the $90-140$ year Gleissberg cycle, while the c. 309-year cycle is attributed to the 300-year overtone of the 2115-year Hallstadt cycle. This research is part of a multi-proxy project mandated to determine late Holocene climate variability along the route of the economically important Tibbitt to Contwoyto Winter Road (TCWR), a seasonal ice road that stretches $600 \mathrm{~km}$ from Yellowknife to Nunavut.
\end{abstract}




\section{Preface}

Given the enormity of the ice road project, a significant amount of collaboration was involved during this research. Having said that, I was fully involved in setting up and carrying out the research, obtaining data and analyzing results, as well as preparing and writing the multi-author manuscripts presented in this thesis. Specifically, I was responsible for carrying out subsampling, diatom preparation and enumeration, as well as subsequent interpretation of data from the Danny's Lake freeze core. Input from colleagues came in the form of aiding in data analysis and interpretation, as well as reviewing manuscripts. In addition, I had access to age models, loss on ignition and magnetic data, which was shared between all collaborators who are studying the Danny's Lake core. Persons involved in any aspect of this project are acknowledged.

The manuscript presented in Chapter 2 of this thesis was written solely by myself, and will include the following additional authors when submitted for publication in the peer-reviewed literature; Andrew L Macumber, Jesse C Vermaire, R Timothy Patterson, Carley Crann, Helen M Roe, Jennifer M Galloway and Hendrik Falck. Please see Appendix A for a detailed declaration of involvement for each co-author on this paper.

The manuscript presented in Chapter 3 was written solely by myself, and will include the following authors when submitted for publication in the peer-reviewed literature; Andrew L Macumber, R Timothy Patterson, Graeme T Swindles, Helen M Roe, Jennifer M Galloway and Hendrik Falck. Please see Appendix A for a detailed declaration of involvement for each co-author in this paper. 


\section{Statement of Supervisor}

April Sue Dalton was fully involved in setting up and conducting the research, obtaining data and analyzing results, as well as preparing and writing the material presented in the co-authored articles integrated in this thesis.

R Timothy Patterson

Date 


\section{Acknowledgements}

This project would not have been possible without a dedicated research team, which was headed by Dr. Tim Patterson. I wish to firstly thank him for introducing me to the Ice Road project and encouraging me to pursue this research. I am truly grateful for this opportunity.

I would secondly like to recognize Andrew L Macumber, Fritz Griffith and Carley Crann who both acted as a mentors, friends and teammates on the entire Danny's Lake project.

Thirdly, I would like to thank Helen Roe and Jesse Vermaire for teaching me how to process and identify the various species of diatoms that I encountered, as well as aiding in diatom ecology and interpretation. Both Jennifer Galloway and Hendrik Falck shared their knowledge on the boreal region of the Northwest Territories. Their assistance with logistical support and fieldwork was invaluable. Help with statistics, wavelet and spectral analysis, as well as data interpretation was graciously provided by Graeme Swindles.

Financial support for this research was provided by the Natural Sciences and Engineering Research Council of Canada (NSERC) strategic project grant to RTP, as well as financial and in-kind support from the Geological Survey of Canada, the Northwest Territories Geoscience Office, the North Slave Métis Alliance, and the Tibbitt to Contwoyto Winter Road Joint Venture. Support was also provided by the Polar Continental Shelf Program (PCSP) and Northern Scientific Training Program (NSTP), grants provided by the Northwest Territories Cumulative Impact Monitoring Program (CIMP) and the Northwest Territories Geosciences Office (NTGO). In addition, I would 
like to thank the staff of the Tibbitt to Contwoyto Winter Road Joint Venture who provided important logistical support for field-work in this challenging region, as well as Robert Mercredi for assistance in core collection.

I would like to acknowledge the Dr. George A. Jeletzky Memorial Scholarship, awarded to students pursuing studies in the field of paleontology, for providing me with financial assistance. I am also grateful to my committee members, Dr Konrad Gajewski and Dr Paul Gammon, who graciously took time out of their busy summer schedules to serve on my committee.

Finally, I would like to thank family and friends who supported me along this journey. 


\section{Table of Contents}

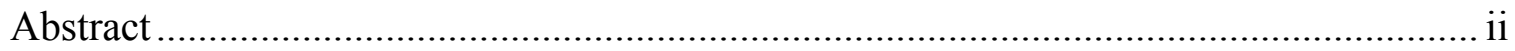

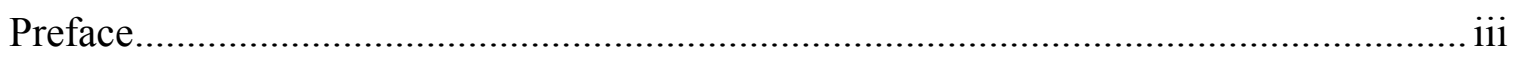

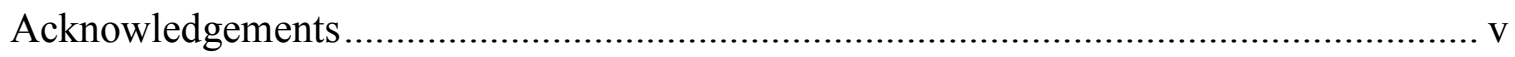

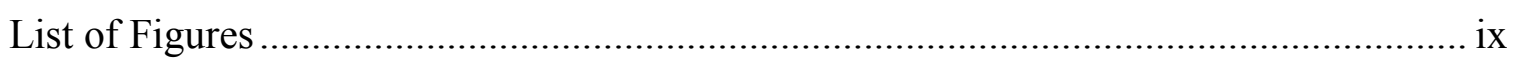

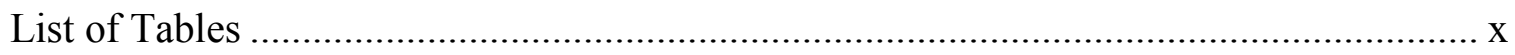

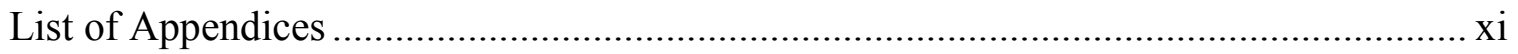

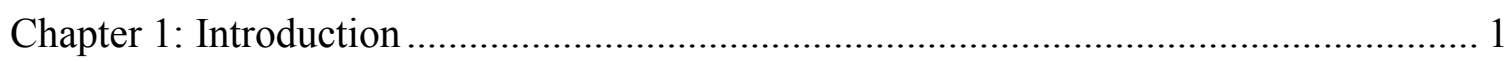

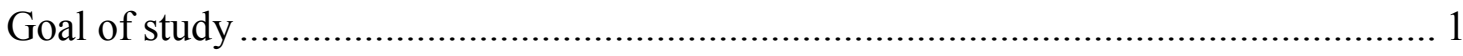

Climate of Northwest Territories and Tibbitt to Contwoyto Winter Road .................... 1

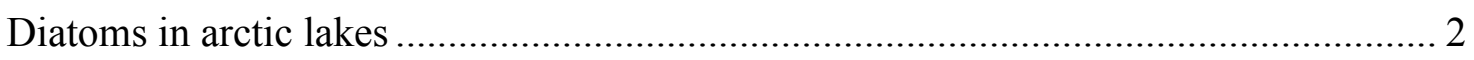

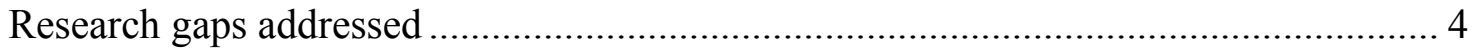

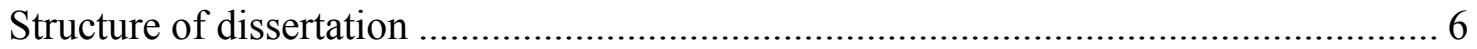

Chapter 2: A 3330-year Multi-Proxy Climate Record from Canadian Subarctic: Detection of Storm event at 1100 cal. yr BP and Potential for Time-series Analysis ...................... 7

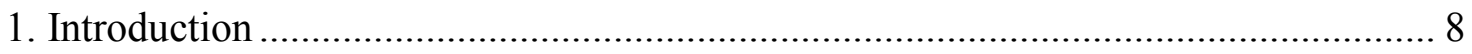

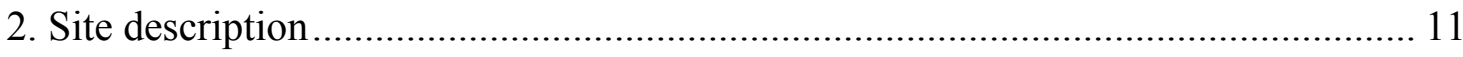

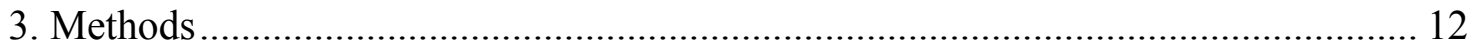

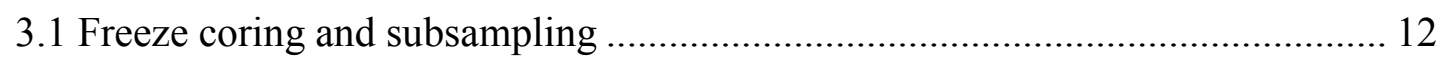

3.2 Radiocarbon dating and Bayesian age-depth modelling ................................ 12

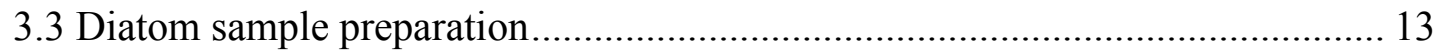

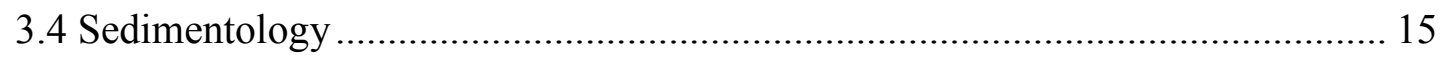

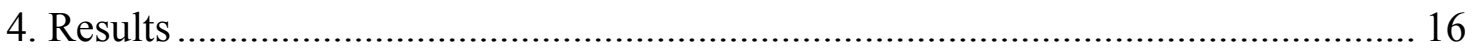

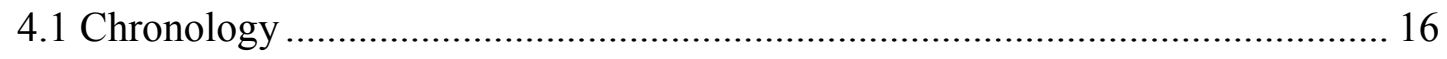

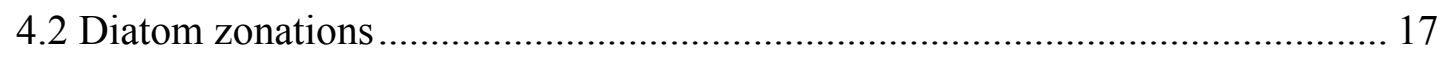

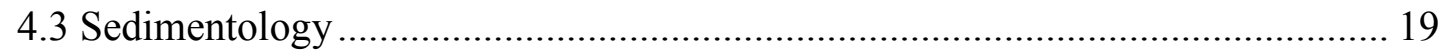

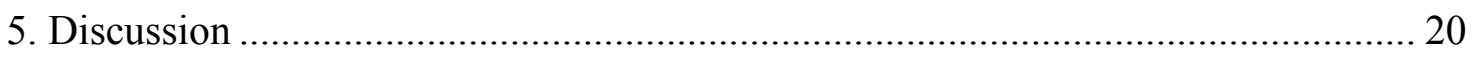

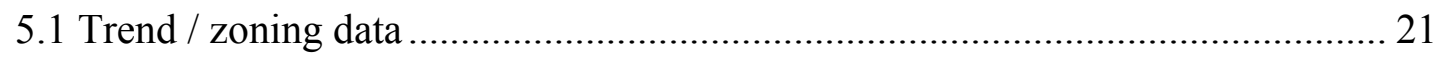

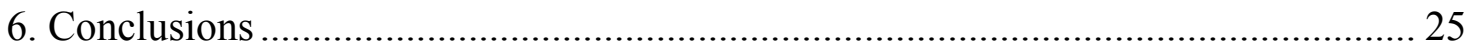

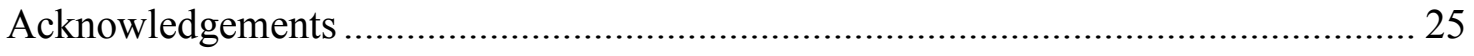


Chapter 3: Diatom Data Reveal Solar Forcing as a Late Holocene Climate Control in Canadian Subarctic

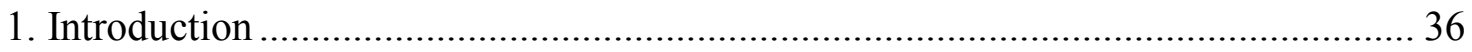

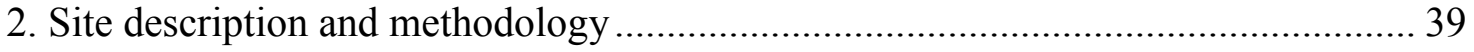

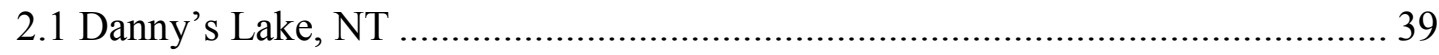

2.2 Freeze coring and diatom procedure .......................................................... 41

2.3 Diatom groups chosen for spectral / wavelet analysis .................................... 41

2.4 Radiocarbon dating and age depth modelling ............................................ 42

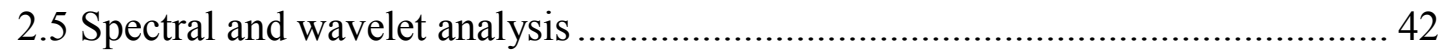

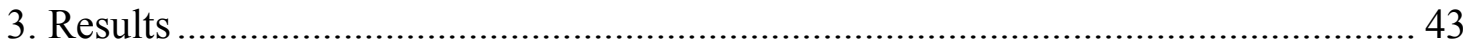

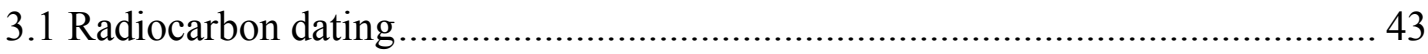

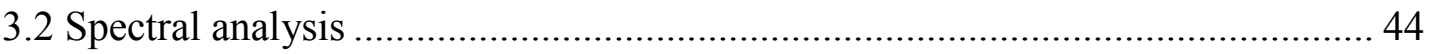

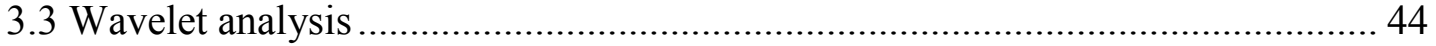

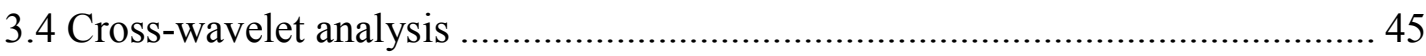

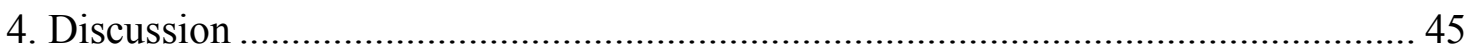

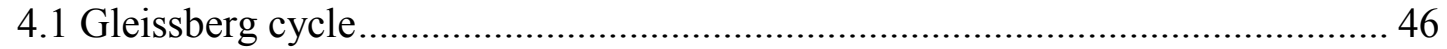

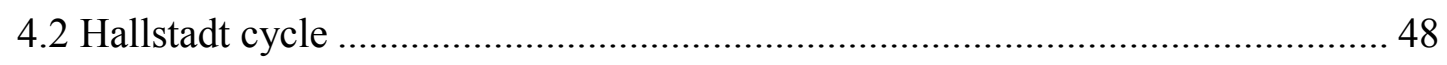

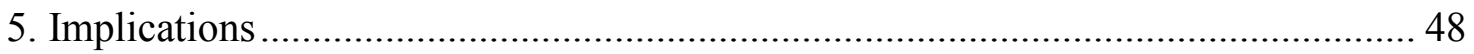

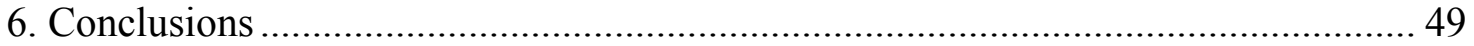

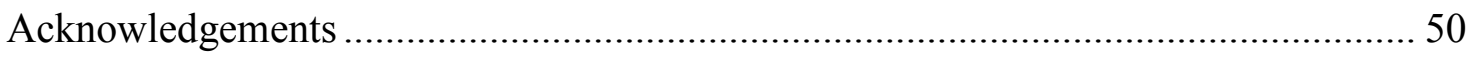

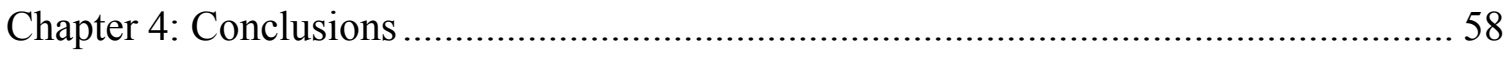

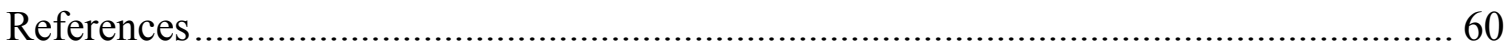

Appendix A. Co-author involvement declaration forms....................................... 71

Appendix B. Diatom species names and authorities according to Krammer \& Lange-

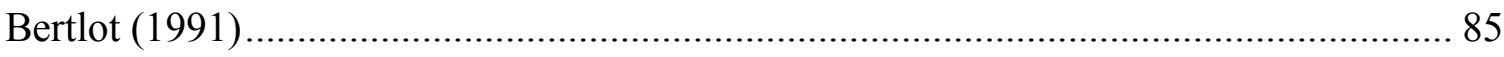

Appendix C. Comprehensive diatom counts for the Danny's Lake sediment core .......... 92 Appendix D. List of stratigraphic and sedimentary values for the Danny's Lake sediment

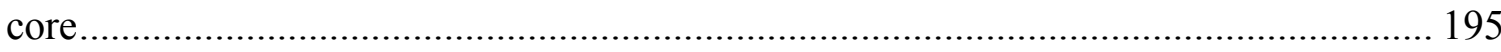

Appendix E. Diatom and TSI data for time-series analysis........................................ 209

Appendix F. Age-depth information for the Danny's Lake sediment core ................... 227 


\section{List of Figures}

Figure 1.1 Common Aulacoseira complex and Pseudostaurosira

complex found in the Danny's Lake core..

Figure 2.1 Location of Danny's Lake. Inset showing location the region

and of coring site

Figure 2.2 Bayesian age-depth model for Danny’s Lake.

Figure 2.3 Stratigraphic plot of each diatom species that reached a relative abundance of greater than 2\% in the Danny's Lake sediment core.

Figure 2.4 Sedimentological proxies for Danny's Lake zoned using diatom grouping

Figure 3.1 Location of Danny's Lake, located south of the treeline transition in the Northwest Territories.

Figure 3.2 Bayesian age-depth model for Danny’s Lake

Figure 3.3. REDFIT spectral analysis results for Aulacoseira complex and Pseudostaurosira complex.

Figure 3.4 Wavelet results for Aulacoseira complex and

Pseudostaurosira complex

Figure 3.5 Cross-wavelet analysis for TSI and Aulacoseira complex and TSI and Pseudostaurosira complex. 


\section{List of Tables}

Table 1.1 Summary of paleolimnology studies from the treeline region of the Northwest Territories, Canada.........................................................................................

Table 2.1 Water chemistry variables taken at specified depths of Danny's lake in

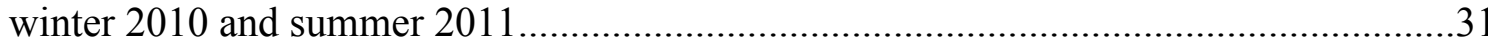

Table 2.2 Diatom species groupings included in stratigraphic diagram...........................32

Table 2.3 Danny's Lake AMS radiocarbon results........................................................33

Table 3.1. Summary of downcore relative abundance values and PCA axis for Aulacoseira complex and Pseudostaurosira complex .......................................... 56

Table 3.2 Radiocarbon results for Danny's Lake...........................................................57 


\section{List of Appendices}

Appendix A. Co-author involvement declaration forms........................................ 71

Appendix B. Diatom species names and authorities according to Krammer \& Lange-

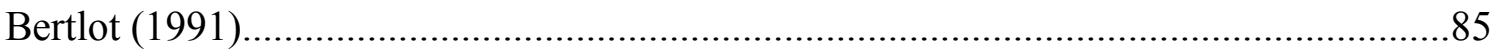

Appendix C. Comprehensive diatom counts in the Danny's Lake sediment core............92

Appendix D. List of stratographic and sedimentary values for Danny's Lake................195

Appendix E. Diatom and TSI data for Spectral Analysis........................................209

Appendix F. Age-depth information for the Danny's Lake core .................................227 


\section{Chapter 1: Introduction}

\section{Goal of study}

Diatom assemblages were examined from a record that spanned the last $\sim 3300$ years of the late Holocene in a freeze core collected from Danny's Lake, Northwest Territories (NT), Canada. The goal of this study was; (1) to quantify trends and natural modes of subarctic climate variability through the late Holocene period using diatom populations as proxies; (2) to determine whether diatom-derived late Holocene climate trends and cycles could be recognized based on time-series analysis; and (3) to employ select diatom assemblage components, which have previously been used to infer past icecover elsewhere, and by extension temperature, in the Danny's Lake core. For example, certain benthic taxa of the Pseudostaurosira complex tend to flourish under ice-covered conditions where light penetration is significantly reduced, while planktic species attributable to Aulacoseira complex tend thrive under ice-free conditions during windinduced turbulence of the lake. This research is of significance to planners and policy makers as they strive to understand the nature of climate variability and possible future climate conditions along the route of the Tibbitt to Contwoyto Winter Road (TCWR).

\section{Climate of Northwest Territories and Tibbitt to Contwoyto Winter Road}

Northern regions have been referred to as the "miners' canary" of climate change due to their sensitivity to even slight climate variability (Lim et al., 2007). The reason that high latitude regions are so responsive to climate variability is because of the positive albedo feedback link between snowmelt and absorption of solar radiation (ACIA, 2004). Even minor arctic warming has far reaching implications, including the raising of global 
sea levels due to the melting of polar ice and possible ecological consequences related to habitat loss (ACIA, 2004).

The TCWR is $88 \%$ built on frozen lakes and stretches $600 \mathrm{~km}$ northeast from Contwoyto Lake, NT, into Nunavut. This winter-only transportation route serves as the main corridor for getting critical mining supplies (e.g. fuel, tires, concrete, heavy equipment) to mine sites in the central NT and southern Nunavut. In 2006, the central NT was impacted by an especially mild and stormy winter related to the El Niño of that year. Due to unseasonably mild conditions, the TCWR was forced to cease operations a month early, which caused serious economic losses and the closing of one mine. In 2009, a NSERC strategic project grant was awarded to RT Patterson and collaborators which was mandated to determine the nature of natural climate cycles impacting this region through the last $\sim 3500$ years of the late Holocene, and to provide an indication of possible future climate variability in the region.

\section{Diatoms in arctic lakes}

The retreat of the Laurentide ice sheet in the central NT, 9000 years before present (Dyke and Prest, 1987) resulted in the formation of many shallow lakes on the Canadian Shield, which underlays most of the boreal forest region. These shallow lakes

are strongly influenced by seasonal weather conditions (Adrian et al., 1999; Kohler \& Hoeg, 2000), thus making perfect reservoirs to capture a record of past climates. Diatoms (Class Bacillariophyceae) are single-celled protists that are found worldwide in most lacustrine environments. They are sensitive limnological indicators because of speciesspecific responses associated with changes in light availability, lake chemistry, nutrient 
availability and water temperature (Adrian et al., 1999). If bioturbation is not severe, analysis of lake sediments containing benthic and planktic faunas can provide a valuable overview of the evolution of the entire lake ecosystem.
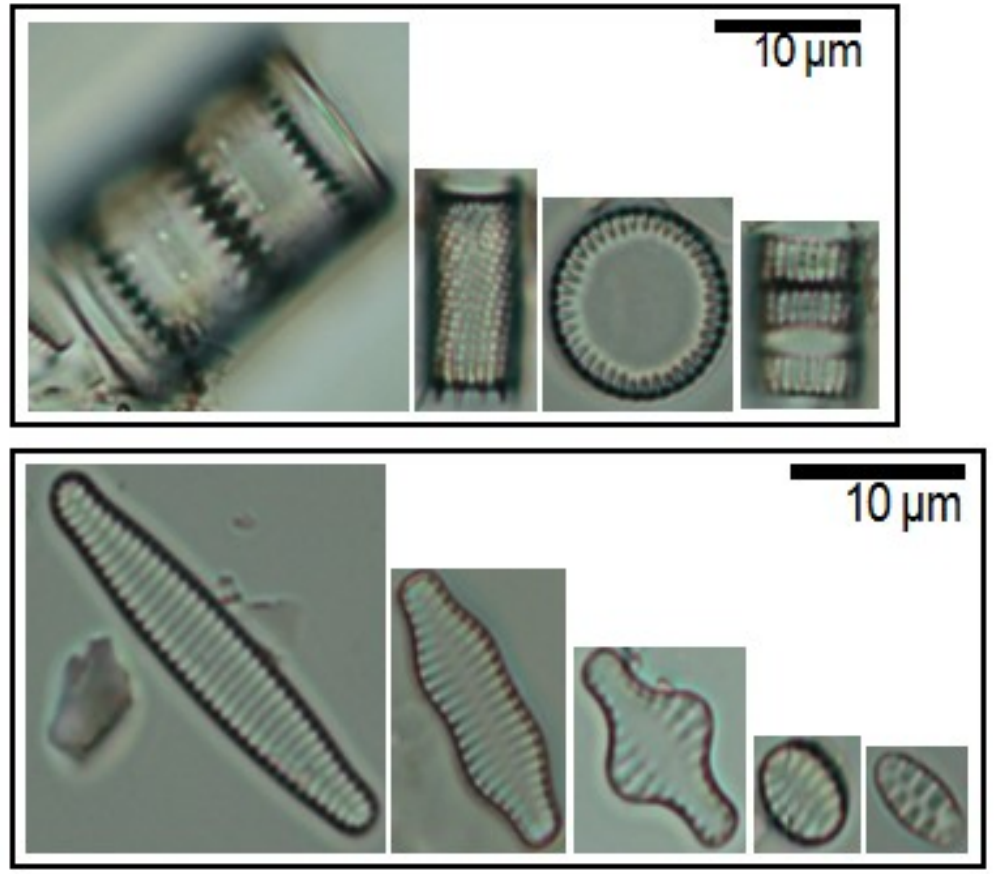

Figure 1.1. Common Aulacoseira complex and Pseudostaurosira complex found in the Danny's Lake core. From left to right: A perglabra, A subarctica, A alpigena, A distans. Bottom - Common Pseudostaurosira complex species found in the Danny's Lake core. From left to right: Staurosira construens var. exigua, Staurosira construens var. binodis, Pseudostaurosira pseudoconstruens, Staurosira construens var. venter, Staurosirella pinnata.

This research takes advantage of the utility of diatoms to infer past climate conditions. Of particular importance are two species groups, which are prominent in Danny's Lake: benthic Pseudostaurosira complex (Figure 1.1), which tend to flourish under ice-covered conditions where light penetration is significantly reduced (Smol, 
1988) and planktic Aulacoseira complex (Figure 1.1), which require turbulent lake condition to thrive (Korhola, 1996; Sorvari \& Korhola, 1998), thus past wind conditions can be inferred. In addition, Achnanthidium minutissimum live attached to the substrate of the lake, and have been demonstrated to be prone to habitat disruption caused by increased turbulence (Barnese \& Lowe, 1992). Based on this characteristic, this species can be used to provide an indication of past wind and storm conditions.

\section{Research gaps addressed}

Most other studies in this region have focused on lakes located on the tundra, whereas this project is focused on a lake within the boreal forest (see Table 1.1). This project is unique because it is based on high-resolution data analysis of 6 years per sediment sample covering the past 3300 years, where the previous studies focused on broader Holocene timescales at lower resolution, as seen in Table 1.1. In addition, Chapter 3 documents the results of a time-series analysis of the diatom floras, which reveals considerable information on the nature of stationary and non-stationary trends and cycles that have characterized the late Holocene. Similar time-series analysis has not yet been conducted in the central NT.

High-resolution studies have the ability to reveal short-lived or high frequency climate events. Our study employs an unprecedented 6-year resolution for the Canadian North, enabled by the use of freeze coring and a custom-designed sledge microtome. The most obvious benefit of conducting a paleolimnological study at such a resolution is the 
Table 1.1 Summary of paleolimnology studies from the treeline region of the Northwest Territories, Canada. "Loc" refers to the lake and "Res" refers to the estimated number of years represented in each sample of the study.

\begin{tabular}{|c|c|c|c|c|c|}
\hline Lake & Loc & Proxy & $\begin{array}{l}\text { Max } \\
\text { yrBP }\end{array}$ & Res & Publication \\
\hline P-49 & Tundra & $\begin{array}{l}\text { chironomids, } \\
\text { sedimentology }\end{array}$ & 6500 & 30 & $\begin{array}{l}\text { Upiter et al., 2013, in } \\
\text { review }\end{array}$ \\
\hline S41 & Tundra & chironomids & 2857 & 40 & MacDonald et al., 2009 \\
\hline TK-2 & Tundra & diatoms & 9056 & 80 & Paul et al., 2010 \\
\hline McMaster & Tundra & pollen & 6180 & 500 & $\begin{array}{l}\text { Moser and Macdonald, } \\
1990\end{array}$ \\
\hline Queen's & Tundra & diatoms, pollen & 6150 & 600 & Macdonald et al., 1993 \\
\hline Slipper & Tundra & diatoms & 5660 & 140 & $\begin{array}{l}\text { Macdonald et al., 1993; } \\
\text { Rühland and J. Smol, } 2005\end{array}$ \\
\hline Toronto & Tundra & $\begin{array}{l}\text { diatoms, } \\
\text { isotopes, pollen }\end{array}$ & 7040 & 125 & Wolfe et al., 1996 \\
\hline UCLA & Tundra & pollen & 8500 & 100 & Huang et al., 2004 \\
\hline Waterloo & Tundra & pollen & 7640 & $?$ & Macdonald et al., 1993 \\
\hline Danny's & Boreal & diatoms & 3300 & 6 & This dissertation \\
\hline
\end{tabular}

ability to see proxy-based lake conditions over a much shorter time interval. Decadalscale or finer reconstructions of environment are most applicable for land-use planners. Furthermore, most mineral-based industry projects in the NT have an operating life on a decadal-scale so this resolution of environmental study is relevant. The only other study in our region that documented a pronounced cool and windy period at approximately 1400 cal. yr BP (Upiter et al., 2013, in review) was also conducted at a decadal-scale resolution. 


\section{Structure of dissertation}

This thesis is primarily comprised of two manuscripts, which have been formatted for submission to specific journals. Input from co-authors and committee members will be incorporated into the manuscripts prior to submission for publication. Both manuscripts are based on the same diatom dataset from Danny's Lake, but utilize different methods to reveal the nature of past climate variability in this region. The manuscript presented in Chapter 2 focuses on down-core diatom trends through the late Holocene at Danny's Lake, NT. In this study, three diatom diatom assemblages are recognized that correspond to chronologically distinct limnological conditions that prevailed at Danny's Lake. This manuscript is being prepared for submission to Palaeogeography, Palaeoclimatology, Palaeoecology. The manuscript in Chapter 3 focuses on spectral and wavelet analysis of the Aulacoseira complex and Pseudostaurosira complex. Time-series analysis is a particularly useful tool for recognizing trends and cycles in climate proxy records. This manuscript is being prepared for submission to Earth and Planetary Science Letters. References for all chapters are presented in the style of Earth and Planetary Science Letters and listed at the end of the thesis. 


\title{
Chapter 2: A 3330-year Multi-Proxy Climate Record from Canadian Subarctic: Detection of Storm event at 1100 cal. yr BP and Potential for Time-series Analysis
}

\author{
Dalton, $\mathrm{AS}^{1}$; Macumber, $\mathrm{AL}^{1}$; Vermaire, $\mathrm{JC}^{2}$; Patterson, $\mathrm{RT}^{1}$; Roe, $\mathrm{HM}^{3}$; Crann $\mathrm{C}^{1}$; \\ Galloway, $\mathrm{JM}^{4}$; Falck, $\mathrm{H}^{5}$
}

(1) Ottawa-Carleton Geoscience Centre, Carleton University, Ottawa, Ontario

(2) Carleton University Paleoecological Laboratory, Ottawa, Ontario

(3) School of Geography, Archaeology and Palaeoecology, Queen's University of Belfast, Belfast, UK

(4) Natural Resources Canada / Ressources naturelles Canada, Geological Survey of Canada / Commission geologique du Canada, Calgary, Alberta

(5) Northwest Territories Geoscience Office, Yellowknife, Northwest Territories

\begin{abstract}
Freeze coring, paired with sampling using a sledge microtome, provides an important advance in high-resolution paleoclimate studies. We examine diatom assemblages from Danny's Lake, located $50 \mathrm{~km}$ south of the modern-day treeline in the Northwest Territories (NT), Canada. The diatom record indicates that climate in this region has been fairly stable over the past 3330 cal. yr BP, although subtle shifts in diatom assemblages suggest small-scale climate changes. The overall trend shows an increase in abundance of the heavily silicified Aulacoseira complex, coupled with a decline of Pseudostaurosira complex. At the beginning of the record, we infer cool conditions and low wind. This is evidenced by the high Pseudostaurosira complex, which thrive under conditions of increased ice-cover, along with low Aulacosiera
\end{abstract}


complex, which require turbulent lake condition to thrive in the photic zone. There is evidence of a period of active weather from 1480 - 1090 cal. yr BP, by means of a decrease in benthic Achnanthidium minutissimum, an increase in sediment grain size, and significant fluctuations in the magnetic susceptibility data through this interval. Evidence of the Medieval Warm Period (1040 - 970 cal. yr BP) at this site is provided by an increase in the relative abundance of Discostella stelligera complex, known to be an indicator of warmer surface waters. In recent times, the stabilization of diatom populations at Danny's Lake suggests a stable climate, which persists into present-day.

\section{Keywords}

Holocene, diatoms, paleolimnology, treeline, Northwest Territories, high-resolution, sledge microtome, freeze core, fresh water effect

\section{Introduction}

Northern regions of Canada are expected to be disproportionately affected by predicted climate warming. Northern Canada has warmed by $1.5-2^{\circ} \mathrm{C}$ each decade since 1980, and climate model projections suggest that this warming will continue through the coming decades (ACIA, 2004). In the Northwest Territories (NT), Canada, evidence of this warming has been marked by a shift, beginning in the 19th century, of diatom communities from assemblages dominated by benthic flora to diatom assemblages dominated by planktic flora in lakes located $50 \mathrm{~km}$ (Rühland and Smol, 2005) and 265 km (Paul et al., 2010) north of the present-day treeline. In both cases, these changes were attributed to a decrease in winter ice-cover extent and duration, ultimately caused by a warmer climate. 
The treeline in the NT corresponds to the position of the Arctic front during summer months (Bryson et al., 1969), which impacts regional air temperature, precipitation patterns and albedo (Macdonald et al., 1998). As a result, different biomes are seen on either side of this vegetation divide. Adding to the importance of the Arctic treeline is the sensitivity of the organisms inhabiting this region as they are often living close to their ecological tolerances (Wolfe et al., 1996; Macdonald et al., 1998; Pienitz et al., 1999; Rühland \& Smol, 2002; Lloyd et al., 2003; Seppa et al., 2003). This area has been poorly studied in the NT (Huang et al., 2004; Peros et al., 2010), and a better understanding of how climate affects the transition across the treeline is needed (Macdonald et al., 1998; Huang et al., 2004) in order to better understand the timing and magnitude of past and future climate changes.

Present-day climate in the north and Pacific regions of Canada was established approximately 3500 years ago, with the onset of late Holocene neoglaciation (KarstRiddoch et al., 2005; Rühland \& Smol, 2005; Miller et al., 2010). Late Holocene conditions have been relatively stable ( $3500 \mathrm{yr} \mathrm{BP}-$ present-day), in part due to the relatively stable solar insolation at $65^{\circ} \mathrm{N}$, which has been at a plateau since approximately 3500 yr BP (Berger et al., 1991; Steinhilber et al., 2009). There have, however, been major excursions in solar insolation through this interval that correlate well with panhemispheric events such as the Medieval Warm Period (MWP) and the Little Ice Age (LIA). These past climate changes may be used as analogues of how ecosystems respond to predicted climate change in northern Canada.

This research project is part of a much larger multi-proxy research study mandated to assess the impact of climate change on the long-term viability of the Tibbitt 
to Contwoyto Winter Road (TCWR). This transportation route stretches $600 \mathrm{~km}$ from near Yellowknife, NT, northward across the treeline and into southern Nunavut (Figure 2.1). The TCWR is built primarily on frozen lakes and is the only overland access route for numerous diamond mines and mineral development projects in the region. The work was initiated in the wake of warmer-than-usual temperatures and increased storminess during the winter of 2006, brought on by an El Niño-Southern Oscillation event. That year, the TCWR season was shortened by 26 days below average, which led to significant financial losses for mining companies and sparked interest in having a better understanding of the climate variability in this region. With continued mining activity along the TCWR, policy makers and planners require a better understanding of the impact of climate change and natural climate variability in this region.

This research is focused on a paleolminological assessment of sediments from Danny's Lake, one of the numerous lakes located in the boreal forest portion of the TCWR, just south of the present-day treeline. A multi-proxy approach is employed to better understand how past changes in late Holocene (last 3500 years) climate in the NT has impacted the Danny's Lake ecosystem. Diatoms (Class Bacillariophyceae) have been demonstrated to be sensitive indicators of environmental change (Smol, 1988). In arctic ecosystems, certain benthic taxa (Pseudostaurosira complex) flourish under ice-covered conditions where light penetration is significantly reduced, while planktic species (Aulacoseira complex) thrive under ice-free conditions and often in turbulent surface water (Korhola, 1996; Sorvari \& Korhola, 1998). Diatom populations can also be used to infer past storm events. For example, a decrease of Achnanthidium minutissimum, which thrive on the lake substrate, is often a sign of habitat disturbance caused by increased 
wind or precipitation (Barnese and Lowe, 1992). By understanding past climate variability in the NT, land-use managers will be better equipped to recognize, plan for, and respond to future climate change.

\section{Site description}

Danny's Lake $\left(6328.547^{\circ} \mathrm{N} ;-11232.785^{\circ} \mathrm{W}\right)$ is located in the present-day boreal forest region of the NT, approximately $150 \mathrm{~km}$ northeast of Yellowknife and $50 \mathrm{~km}$ south of the modern-day treeline (Figure 2.1). The catchment of Danny's Lake is underlain by Archean granitic gneiss bedrock consisting of an amphibolite-grade paragneiss to quartz biotite schist (Stubley, 1990; Davis et al., 1996). The land surrounding our study site is sparsely vegetated with black spruce (Picea mariana), white spruce (Picea glauca) and smaller amounts of tamarack (Larix larincina) and pine (Pinus L.). Climate in the Danny's Lake area is continental, alternating between long, cold winters (average January temperature $-26.8^{\circ} \mathrm{C}$ ) to brief cool summers (average July Temperature $16.8^{\circ} \mathrm{C}$ ). Average annual precipitation is $164.5 \mathrm{~mm}$ (Environment Canada, 2013).

Danny's Lake has a surface area of $0.19 \mathrm{~km}^{2}$ (Figure 2.1) and maximum depth of $10 \mathrm{~m}$. This lake was not thermally stratified when measured in August, 2011 (Table 2.1) The lake has an ephemeral inlet at its northeastern-most extent, and an outlet at the opposite southwestern end (Figure 2.1). 


\section{Methods}

\subsection{Freeze coring and subsampling}

A $116.2 \mathrm{~cm}$ long sediment core was retrieved from a $4.4 \mathrm{~m}$ deep sub-basin of Danny's Lake using a custom-designed two-faced freeze coring device (Galloway et al., 2010; Macumber et al., 2012). The sediment core was kept frozen and transported to Carleton University for analysis. Both faces of the core were sectioned into $0.1 \mathrm{~cm}$ subsamples using a custom-built sledge microtome (Macumber et al., 2011), and slices were allocated to several research projects. We allocated one slice every $0.5 \mathrm{~cm}$ until 56.3 $\mathrm{cm}$ to this diatom study in order to focus on limnological change over the past $\sim 3500$ cal. yr BP.

\subsection{Radiocarbon dating and Bayesian age-depth modelling}

Twenty-five bulk sediment samples were chosen for accelerator mass

spectrometry (AMS) ${ }^{14} \mathrm{C}$ dating at the ${ }^{14} \mathrm{CHRONO}$ Centre for Climate, The Environment, and Chronology at Queen's University, Belfast, United Kingdom. All samples underwent a standard hydrochloric acid wash to remove carbonate material. Radiocarbon ages were calibrated using Calib software version 6.1.0 (Stuiver \& Reimer, 1993) and the IntCal09 calibration curve (Reimer et al., 2009). Since bulk sediment samples at high latitudes commonly incorporate old carbon (eg. Abbott \& Stafford, 1996), we calculated the freshwater reservoir effect (FRE) based on the projected age of the sediment-water interface from an age-depth model constructed in Clam (Crann et al., 2013 in prep.). The Clam model was constructed using a smooth spline with the smoothing parameter set to 0.7 and seven outliers were removed using the general outlier model (Bronk Ramsey, 2009a) in OxCal version 4.1 (Bronk Ramsey, 2009b). The calculation of the FRE is 
based on the assumption that the sediment-water interface should yield an age close to the year the core was collected and also that the FRE has not changed over the past 3500 years. We are confident that the sediment-water interface was captured during freeze coring and was deposited in 2010. The FRE was subtracted from uncalibrated radiocarbon dates before Bayesian age-depth modelling was undertaken.

The age modeling procedure for Bacon is similar to that outlined in Blaauw and Christen (2011), but more numerous and shorter sections are used to generate a more flexible chronology (Blaauw \& Christen, 2011). We used the memory properties suggested for lake sediment cores, with "strength" of 20 and a mean of 0.1 . The accumulation mean of $80 \mathrm{yr} / \mathrm{cm}$ is based on a summary of accumulation rates for this region by Crann et al.2013 (in prep.) and the accumulation shape was set to 20, which is very high, but setting this parameter high reduced the noise associated with likely outliers.

\subsection{Diatom sample preparation}

Following UCL (2013), approximately 0.5 grams of wet sediment was weighed and transferred into a plastic vial at $0.5 \mathrm{~cm}$ intervals downcore to $56.3 \mathrm{~cm}$ depth. Sediment was treated with $10 \mathrm{ml}$ of $35 \%$ peroxide and heated in an $80^{\circ} \mathrm{C}$ water bath for 6 hours to digest any organic material. One $\mathrm{ml}$ of $10 \% \mathrm{HCl}$ was then added to dissolve any carbonates. After given 24 hours for the diatoms in each vial to settle at the bottom, the majority of the $\mathrm{HCl}$ (approximately $14 \mathrm{ml}$ ) was suctioned off and replaced with deionized water. This procedure was repeated 5 times to ensure most of the $\mathrm{HCl}$ and peroxide had 
been flushed from the samples. Ammonia was added to the final wash to ensure any clay particles remained in suspension and could be removed (UCL, 2013).

Diatom slurries were pipetted onto slides in 4 dilution series and allowed to dry. A cover slide was used to seal each dilution series, using Naphrax as a mounting medium. Diatoms were identified using an Olympus BX51 microscope at 1000X magnification under oil immersion. Diatom species were identified according to Krammer and Lange-Bertalot (1991) by creating transects on the cover slip. At least 400 frustules were identified in each sample in order to obtain statistically significant counts (Patterson \& Fishbein, 1989). Species taxonomy was subsequently updated to reflect present-day naming conventions according to the Academy of Natural Sciences and collaborators (2011). See Appendix B for diatom species names and authorities (after Krammer \& Lange-Bertalot, 1991) along with updated taxonomy (Academy of Natural Sciences and collaborators, 2011) and unique North American Diatom Ecological Database (NADED) identification numbers. Chrysophyte cysts were also enumerated in each sediment sample.

Diatom counts were converted to relative abundance (RE) and a square root data transform was applied. Constrained incremental sum of squares (CONISS) zones were determined using the rioja packing in R (Juggins, 2011; R Development Core Team, 2012) by comparison to a broken stick model (Bennett, 1996). Stratigraphic diagrams were creating using the C2 program (Juggins, 2011) and are comprised of only those species that reached at least $2 \%$ in one sample, after Fishbein \& Patterson (1993). Grouped taxa (Table 2.2) are listed according to similar trends and ecology among 
species (Paul et al., 2010). See Appendix C for a comprehensive list of diatom counts for the Danny's Lake sediment core.

Shannon Diversity Index (SDI) (Shannon, 1948) and the ratio of chrysophyte cysts to diatoms $(\mathrm{C}: \mathrm{D})$ was calculated. The $\mathrm{C}: \mathrm{D}$ ratio may be used to better understand the trophic status of the lake over time, as an increase in chrysophyte cysts may indicate nutrient-poor waters (Smol, 1985). PCA and DCA were performed on all diatom species occurring in at least $2 \%$ in one or more samples.

\subsection{Sedimentology}

Particle size distributions were determined every $0.2 \mathrm{~cm}$, on a separate face of the Danny's Lake freeze core, using a Beckman Coulter LS 13320 Laser Diffraction-Particle Size Analyzer with a Universal Liquid Module (Coulter, 2003). The two separate faces of the freeze core were correlated by matching loss on ignition (LOI), magnetic susceptibility (MS) and color changes. Utilizing a protocol modified from Murray (2002) and van Hengstum et al. (2007), $10 \% \mathrm{H}_{2} \mathrm{O}_{2}$ was added to sub-samples in an $80^{\circ} \mathrm{C}$ water bath to remove organic matter. Grain size statistical parameters were calculated from the results in conjunction with the software package Gradistat v8.0 (Blott and Pye, 2001).

Organic, carbonate and minerogenic content were determined by LOI using a Thermo Scientific Thermolyne Benchtop Muffle Furnace (Model: F48025-60-80) at temperatures of $550{ }^{\circ} \mathrm{C}$ and $950{ }^{\circ} \mathrm{C}$ (Heiri et al., 2001). MS values were obtained by scanning the freeze core with a Bartington MS2B sensor set to low frequency (Dearing, 1999) as described by Sandgren and Snowball (2001) and recorded as standard 
international (SI) units. See Appendix D for a list of stratigraphic and sedimentary values for the Danny's Lake sediment core.

\section{Results}

\subsection{Chronology}

A Bayesian age-depth model was constructed in Bacon based on the 25 radiocarbon dates obtained from the Danny's Lake core (Figure 2.2). According to this model, the average accumulation rate over the past $\sim 3500$ years was 60 years $/ \mathrm{cm}$. As the sledge microtome was set for a $0.1 \mathrm{~cm}$ slicing resolution, each slice represents 6 years. A uniform FRE of 430 years was subtracted from uncalibrated radiocarbon dates prior to constructing the age-depth model in Bacon (Crann et al., 2013 in prep). FREs can be caused by many factors, including: (1) dating submerged aquatic vegetation, which does not readily exchange $\mathrm{CO}_{2}$ with the atmosphere; (2) input of ${ }^{14} \mathrm{C}$ "dead" carbon from bedrock; or (3) the in-wash of old organic material. Based on the $\delta 13 \mathrm{C}$ values obtained during radiocarbon dating (Table 2.3), it was determined that the material dated was terrestrial in origin and not aquatic. It is also known that the old carbon is not likely derived from bedrock, as Danny's Lake is located in a granitic terrain. Therefore, the most likely cause of the FRE at Danny's Lake is the in-wash of old organic material during the spring melt (Crann et al., 2013 in prep). Previous studies have shown that the FRE changes over time (e.g. Barnekow et al., 1998; Saulnier-Talbot et al., 2009) with changes in climate and related changes in lake level, vegetation cover, and erosion (e.g. Stuiver, 1975; Geyh et al., 1998; Grimm et al., 2009; Blaauw et al., 2011), but since the regional climate at Danny's Lake has been fairly stable through the past 3500 years, application of a uniform correction is reasonable for dated sediments deposited during 
this interval. Age-depth information for each $\mathrm{mm}$ slice throughout the examined portion of Danny's Lake sediment core is presented in Appendix F.

\subsection{Diatom zonations}

A diverse diatom flora consisting of 218 species were identified in the Danny's Lake freeze core (Figure 2.3). Over time, there was a general increase in the relative abundance of Aulacoseira complex, with a corresponding decrease in the abundance of Pseudostaurosira complex. Three diatom assemblages were identified using CONISS and by comparison to a broken stick model (Bennett, 1996).

\subsubsection{First late Holocene diatom assemblage $(56.3-32.3 \mathrm{~cm})$}

Results of the SDI analysis show that diatom assemblage composition varied significantly through the $56.3-32.6 \mathrm{~cm}$ section of the sediment core (Figure 2.4). The first late Holocene diatom assemblage is dominated by Aulacoseira alpigena, which had an average $\mathrm{RE}$ of $25.6 \%$, with a maximum abundance of $51.8 \%$ at $36.8 \mathrm{~cm}$ and a minimum abundance of $8.8 \%$ at $52.9 \mathrm{~cm}$. Benthic Pseudostaurosira complex are the second most common species through this interval, having an average RE of $12.1 \%$, reaching a maximum abundance of $20.4 \%$ at $56.3 \mathrm{~cm}$ and minimum abundance of $4.8 \%$ at $38.4 \mathrm{~cm}$. Achnanthidium minutissimum, which live attached to the lake substrate, were characterized by a RE of $6.8 \%$ throughout this interval, which is the highest RE for this species over the entire sediment core. SDI values ranged from 2.1 to 3.3 through the basal part of the studied record. The results of PCA analysis show considerable variability at the bottom of the sediment core, with an average of 0.088 , having a minumim of 0.063 at $52.9 \mathrm{~cm}$ and maximum of 0.095 at $39.7 \mathrm{~cm}$. DCA analysis (Figure 
2.4) has an average value of 85.7 and minimum and maximum axis loadings of 36 and 133, respectively. C:D ratio maintained an average of 11.4 , but saw a high of 16.7 at 55.3 $\mathrm{cm}$ and low of 1.1 at $47.9 \mathrm{~cm}$.

\subsubsection{Active weather diatom assemblage $(32.6-23.3 \mathrm{~cm})$}

A significant shift in diatom composition is noted in this interval. Achnanthidium minutissimum dropped to an average RE of $4.4 \%$ in this zone, indicating decreased habitat preference for the lake substrate. Similar to the first late Holocene diatom assemblage, this interval was dominated by Aulacoseira alpegina, having an average RE of $33.8 \%$, with a high of $42.3 \%$ at $28.9 \mathrm{~cm}$ and low of $24.4 \%$ at $23.9 \mathrm{~cm}$. Cyclotella ocellata is the second most abundant species during this interval, with a relative abundance of $8.3 \%$ with a minimum and maximum RE of $5.1 \%$ and $12.1 \%$ at $26.3 \mathrm{~cm}$ and $31.5 \mathrm{~cm}$, respectively. Pseudostaurosira complex decreases in this section of the core to an average RE of $6.7 \%$. To starkly contrast the first late Holocene diatom assemblage, the PCA and DCA results are more stable during this interval, with minimum and maximum axis loadings of 0.092 to 0.095 and 22 to 72 , respectively. SD index also reflects more stable diatom populations at this time, with an average value of 2.7. Similar to the first late Holocene diatom assemblage, $C: D$ ratio fluctuates from a minimum of 1.9 to a maximum of 13.2 during this interval.

\subsubsection{MWP and LIA diatom assemblage $(23.0-0 \mathrm{~cm})$}

The most recent diatom assemblage $(23.0-0 \mathrm{~cm})$ shows a decreased variability in many diatom species that continues into present-day. Aulacoseira alpegina is, again, the most common species during this interval with an average RE of $31.3 \%$, exhibiting a 
minimum of $19 \%$ at $18.4 \mathrm{~cm}$ and a maximum of $48.1 \%$ at $9.8 \mathrm{~cm}$. The second most common species group is Aulacoseira complex, with an average RE of $14.7 \%$ and a maximum of 29.7 at $9.5 \mathrm{~cm}$ and minimum of 5.4 at $19.6 \mathrm{~cm}$. Achnanthidium minutissimum, shows a recovery from the active weather period to $10.0 \% \mathrm{RE}$ at $22.1 \mathrm{~cm}$ depth, and Cyclotella ocellata remains steady with an RE 6.9\%. During the interval of $22.1-20.5 \mathrm{~cm}$, a sustained RE of greater than $5.5 \%$ is seen in Discostella stelligera complex. This increase is unprecedented in this section of the sediment core. Results from PCA do not vary largely from those seen during the preivious interval, with the exception of 0.078 at $9.4 \mathrm{~cm}$ and 0.079 at $5.1 \mathrm{~cm}$. DCA and SD index values do not change drastically from the previous intervals, but an increase in variability is seen in the $\mathrm{C}: \mathrm{D}$ ratio during this interval.

\subsection{Sedimentology}

\subsubsection{Magnetic susceptibility}

From $32.3-56.3 \mathrm{~cm}$, which corresponds with the first late Holocene diatom assemblage, low frequency MS values are consistently below 0 . The interval from 32.6 $23.3 \mathrm{~cm}$, however, is characterized by increased variability, from a low of -4.1 at $28.0 \mathrm{~cm}$ to a high of 3 at $25.1 \mathrm{~cm}$. From $23.0-0 \mathrm{~cm}$, MS values are mostly less than 0 and display a moderate amount of variability. The minimum MS value in these most recent sediments is -4.4 at $2.8 \mathrm{~cm}$ and the maximum is 2.2 at $16.3 \mathrm{~cm}$.

\subsubsection{Loss on ignition}

The components of LOI, expressed as percent organic, carbonate and minerogenic, are plotted over time in Figure 2.4. LOI data is missing for the top $10.0 \mathrm{~cm}$ 
of the core due to insufficient sediment being available for this analysis. Organic matter fluctuates between $20-40 \%$ throughout the sediment core. Carbonate concentration is consistently less than $7 \%$, with an exception of $7.75 \%$ at $43.0 \mathrm{~cm}$. Minerogenic content makes up $60-80 \%$ of the sediment content throughout the core.

\subsubsection{Grain size analysis}

The majority of the Danny's Lake sediment core is comprised of sandy mud, with an average size of $33.9 \mu \mathrm{m}$. Of important note is a shift from intervals of coarse silt (31 $16 \mu \mathrm{m})$ to intervals of very coarse silt $(63-31 \mu \mathrm{m})$ between 31.0 to $17.1 \mathrm{~cm}$, which corresponds well with the active weather diatom assemblage. During his interval, mean grain size is consistently elevated above the average variability seen within the rest of the core.

\section{Discussion}

With an average of 6 years represented by each sediment sample, this paper is the highest resolution analysis of paleoclimate proxies to date in this subarctic region. Lake S41, located just north of the treeline in the NT, had a similar sedimentation rate of 70 $\mathrm{yr} / \mathrm{cm}$, but analysis was performed at a decadal-scale (30 - 50 year) temporal resolution (MacDonald et al., 2009). Similarly, tundra lake TK-2 had a sedimentation rate of approximately $75 \mathrm{yr} / \mathrm{cm}$, but was hindered by a sampling resolution of $1 \mathrm{~cm}$, yielding 75

year "snapshots" of climate (Paul et al., 2010). Despite Danny's Lake being dominated by only a few diatom species, it is possible to derive evidence of significant ecological change throughout the late Holocene period. 


\subsection{Trend / zoning data}

\subsubsection{First late Holocene diatom assemblage (3330 - 1480 cal. yr BP)}

We infer low wind and cool conditions during this period. This is evidenced by the high Pseudostaurosira complex, which thrive under conditions of increased ice-cover (Smol, 1988), along with low RE of Aulacosiera complex, which require turbulent lake condition to thrive in the photic zone (Korhola, 1996; Sorvari \& Korhola, 1998). The initiation of the late Holocene period (Berger et al., 1991; Luan et al., 2012) is seen in most records in the NT as a prominent southward shift in the treeline around $3500 \mathrm{yr}$ BP (approx. 3776 cal. yr BP) (Pienitz et al., 1999; Huang et al., 2004; Rühland and Smol, 2005; Paul et al., 2010). Pollen data from Danny's Lake show a continued increase in Pteridium, Botrychium abundances during this time period, coupled with the continued decrease in charcoal and Pediastrum abundances which supports the trend of climate continuing to become cooler and wetter (Sulfur, personal communication, 2013). Pollen data from UCLA Lake indicates a shift at 3000 cal. yr BP towards shrub tundra, indicating more cool and dry periods in the tundra farther north (Huang et al., 2004), which coincides with the beginning of the late Holocene period.

\subsubsection{Active weather diatom assemblage (1480 - 1090 cal. yr BP)}

Given our results, we suggest that a period of active weather took place at Danny's Lake from 1480 - 1090 cal. yr BP. During this time period, a decrease in Achnanthidium minutissimum occurred. Achnanthidium minutissimum live attached to the substrate of the lake, and therefore are prone to habitat disruption caused by increased

turbulence. This would indicate cooler air and surface water temperatures during this 
time period, and would have weakened the vertical stability of the water column making it more susceptible to wind-driven mixing.

To corroborate our inferred active weather, grain size data from the c. 1480 - c. 1090 cal. yr BP interval of the Danny's Lake core increase from coarse silt to very coarse silt, which stays consistently elevated throughout his period (Figure 2.4). An increase in grain size would be expected under increased precipitation and windier conditions. An increase in precipitation would result in coarser material being brought in from the catchment, and the increased wind would influence wave energy. This increased wave energy would result in coarser material remaining suspended within the water column over greater distances prior to falling out of suspension. The significant variation in MS observed through this interval provides further evidence that higher precipitation and wind levels characterized this interval. Large variations in this parameter through a sedimentary sequence are often attributed to increased erosion and sedimentation within a watershed (Dearing, 1999; Sandgren \& Snowball, 2001). Relatively close to the Danny's Lake study site, a chironomid-inferred reconstruction of mean July temperatures at Lake P-49 indicates that temperatures reached an all-time late Holocene low of $10.2^{\circ} \mathrm{C}$ at 1540 cal. yr BP (Upiter et al., 2013, in review).

There is also evidence of a similar cooler, higher precipitation and windy period during this time elsewhere in the circumpolar region (Jackson et al., 2005; Reyes et al. 2006; Viau \& Gajewski, 2009; Clegg et al., 2010; Sorrel et al., 2012). A pollen-based Holocene temperature and precipitation reconstruction for the MacKenzie region provided evidence for a significant increase in annual precipitation centered at 1100 cal. yr BP (Viau and Gajewski, 2009), which was unparalleled through the entire late 
Holocene period. Evidence of widespread cooling in British Columbia and Alaska from 1550 - 1250 cal. yr BP has also been inferred from major glacier advances during that time period (Reyes et al., 2006), with high-resolution midge analysis in Alaska yielding evidence of a similar cooling of up to $1^{\circ} \mathrm{C}$ during this time (Clegg et al., 2010).

In studies carried out to the east of Danny's Lake, an increase in westerly winds and cooling in the Arctic during this time period has been attributed to an increase in North Atlantic Ocean surface variability (Jackson et al., 2005; Sorrel et al., 2012). In northern Europe, an increase in sedimentation during the interval from c. 1600 - c. 1250 cal. yr BP at several localities are also attributed to Northern Atlantic Ocean variability, which would also have lead to increased paleo-storm activity (Sorrel et al., 2012). A similarly timed increase in mean grain size for sediments deposited through this interval was observed in Iceland, which was attributed to decreased temperature and increased wind velocities (Jackson et al., 2005).

\subsubsection{The MWP and LIA diatom assemblage (1040 cal. yr BP - present-day)}

At the beginning of this interval, we observe a slight increase in Discostella stelligera complex from 1040 - 970 cal. yr BP. Other studies in this region of the Canadian Arctic, as well as from Finland, have attributed an increase in Discostella stelligera complex to a climate warming, especially with regards to 19th century climate recovery from the LIA (Sorvari \& Korhola, 1998; Rühland \& Smol, 2005; Paul et al., 2010). The MWP has been recognized in other proxy records to have impacted Arctic Canada between c. 1100 - c. 900 yr BP (approx. 1044 - 827 cal. yr BP) (Zabenskie and Gajewski, 2007; D'Arrigo et al., 2009; Paul et al., 2010). In addition, a pollen-based Holocene temperature reconstruction for the MacKenzie region shows a significant 
increase in January temperature anomalies at $1100 \mathrm{cal}$. yr BP (Viau and Gajewski, 2009). MS appears stable, suggesting less erosion and transport in the watershed. Increased restrengthened Achnanthidium minutissimum also suggests a return to more habitable lake substrate post-active weather period.

The LIA is a cooler period typically shown to immediately follow the MWP and lasting from approximately $750-200$ yr BP (approx. $642-221$ cal. yr BP) (Rühland \& Smol, 2005; Finkelstein \& Gajewski, 2008; MacDonald et al., 2009; Paul et al., 2010) does not appear to end in the diatom record for Danny's Lake. In fact, after the increase in Discostella stelligera complex which we attribute to the MWP, the remainder of this assemblage shows a stability which continues into present-day climate conditions.

The warming associated with the end of the LIA in previous studies of the Canadian Arctic and Finland is generally correlated with an increase in Discostella stelligera (Sorvari \& Korhola, 1998; Rühland \& Smol, 2005; Paul et al., 2010). At Slipper Lake, located $100 \mathrm{~km}$ north from our study site, significant ecological shifts were reported in the entire lake diatom assemblage composition after 100 cal. yr BP (Rühland \& Smol, 2005). The Slipper Lake study found that diatom flora underwent a dramatic shift from benthic-dominated to planktic-dominated, which was interpreted as an increased temperature in recent times. At Danny's Lake, Discostella stelligera show no increase in recent times. The lack of increase in this taxa in response to post-LIA warming is unknown. Perhaps warming at the Danny's Lake locality was less pronounced than at open tundra locations such as Slipper Lake. 


\section{Conclusions}

We examined diatom assemblages from the last 23330 cal. yr BP in the boreal region of the NT. The large number of radiocarbon dates obtained from the Danny's Lake core permitted development of a very robust age model. We also successfully demonstrated the usefulness of freeze coring, paired with the sampling with a sledge microtome, which provides an important advance in high-resolution paleoclimate studies. A notable outcome of this research was the detection of an active weather period from 1480 - 1090 cal. yr BP, as evidenced by both diatom assemblage changes and a general increase grain-size. Also of significance was the response of Discostella stelligera to MWP warming, but not to warming in recent times. Although the results of this study provide clear evidence for the onset of the LIA, there is little evidence in neither diatom assemblages, grain size data nor MS data of the $19^{\text {th }}$ century recovery from the LIA at this site. Given the success of this study, we strongly advocate the usage of freeze coring techniques, as well as the sledge microtome for subsampling.

\section{Acknowledgements}

Financial and in-kind support for the "Paleoclimatological assessment of the central NT: Implications for the long-term viability of the Tibbitt to Contwoyto Winter Ice Road" project was provided by a Natural Sciences and Engineering Research Council of Canada (NSERC) strategic project grant to RTP, the Geological Survey of Canada, the Northwest Territories Geoscience Office, the North Slave Métis Alliance, and the Tibbitt to Contwoyto Winter Road Joint Venture. We also acknowledge the support of the Polar 
Continental Shelf Program (PCSP) and Northern Scientific Training Program (NSTP), as well as grants provided by the Northwest Territories Cumulative Impact Monitoring Program (CIMP). We would also like to specifically thank the personnel of the Northwest Territories Geosciences Office (NTGO) for their support, assistance with fieldwork and wealth of knowledge. In addition, we are indebted to the staff of the Tibbitt to Contwoyto Winter Road Joint Venture who provided logistical support for field-work in this challenging region. Staff provided valuable knowledge and assisted in sediment core collection. We particularly thank Robert Mercredi for his assistance in core collection. 


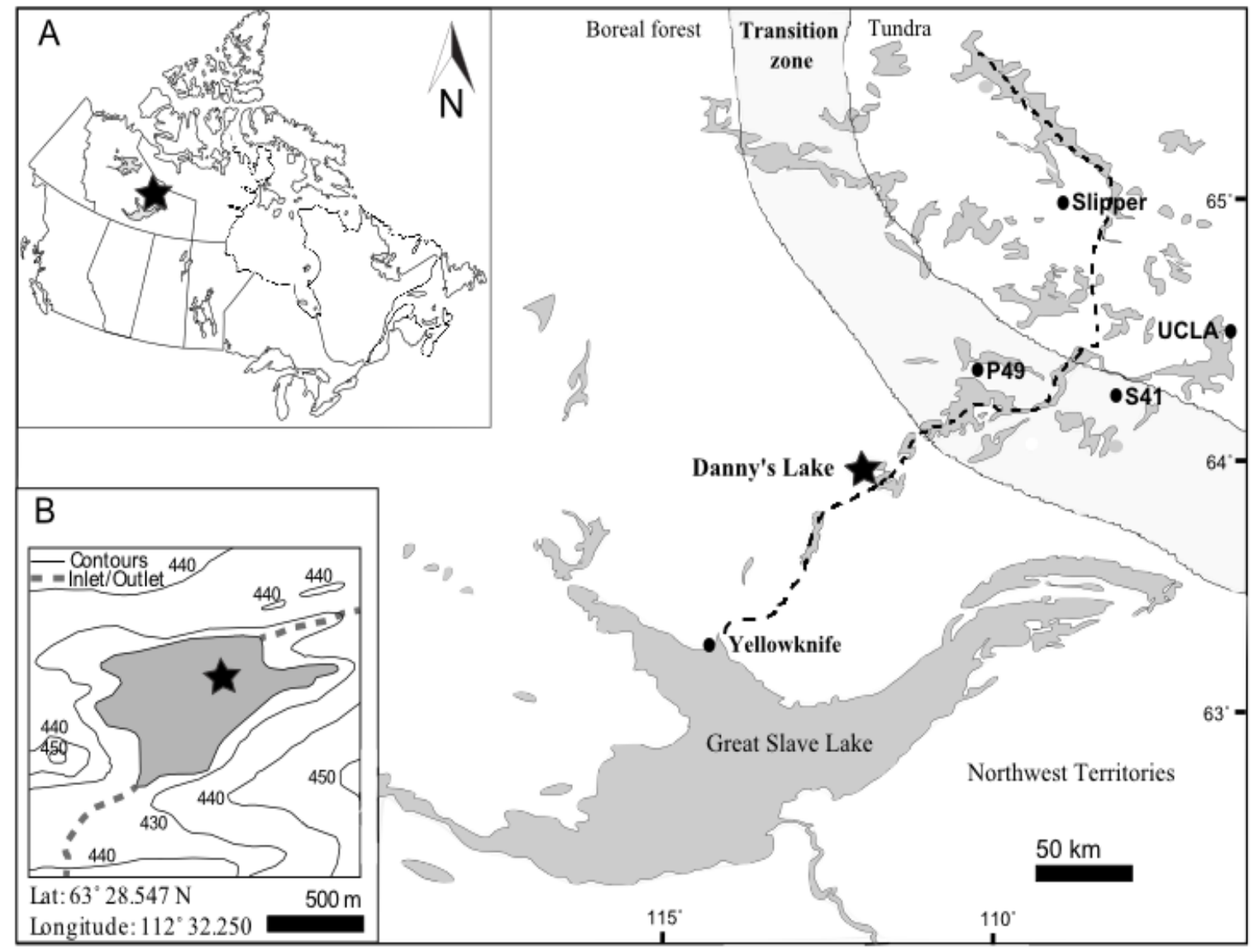

Figure 2.1 Location of Danny's Lake. Inset showing location the region (A) and of coring site (B), as denoted by the star. Other sites including Slipper Lake, Lake P-49, UCLA Lake and Lake S41 are also marked. The dashed line indicates the position of the Tibbitt to Contwoyto Winter Road. The relative position of boreal to tundra transition is also shown. 

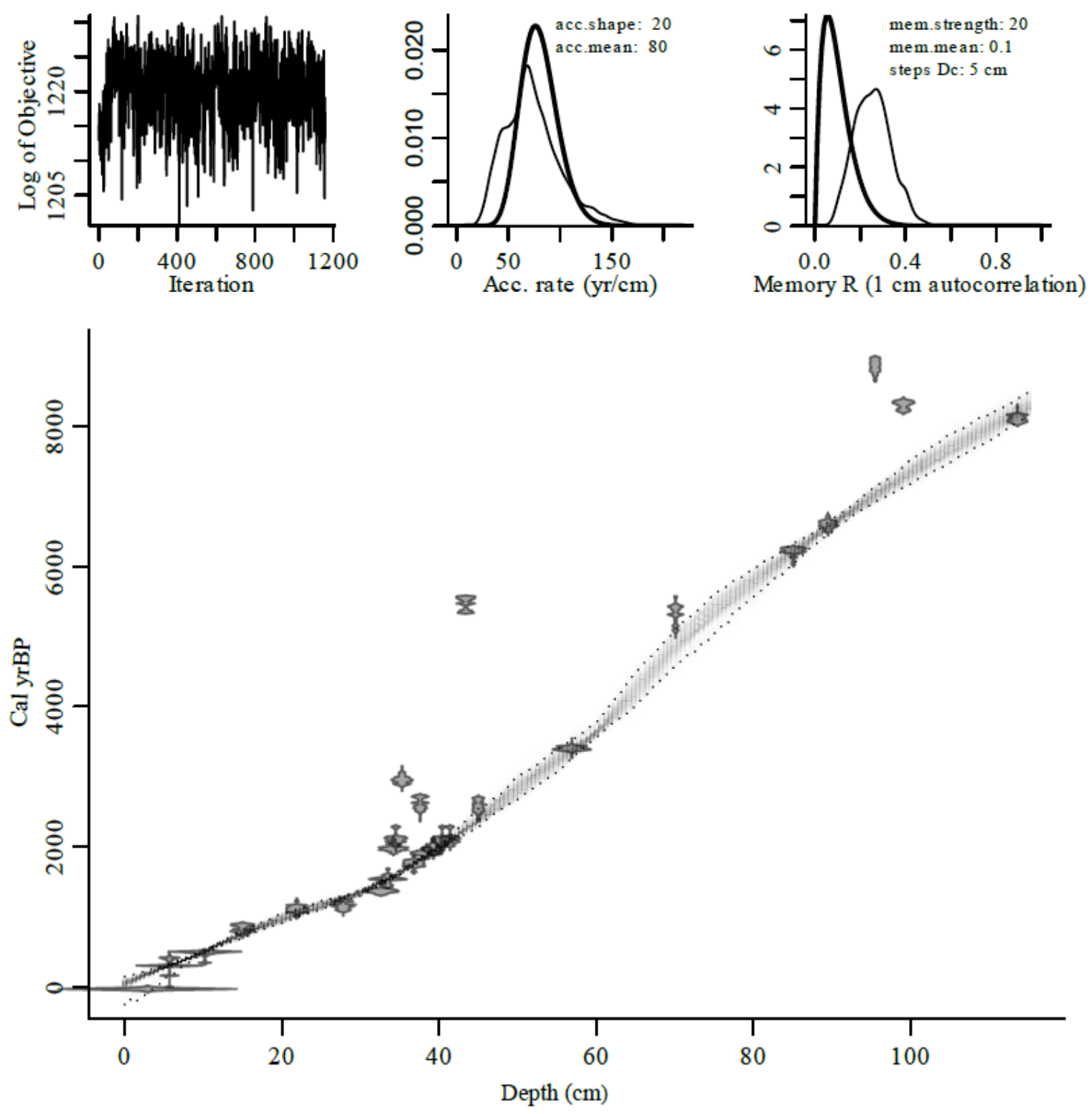

Figure 2.2 Bayesian age-depth model for Danny's Lake. On the top panel, the leftmost plot shows that the Markov Chain Monte Carlo runs were stable (1200 iterations), the middle plot shows the prior (curve) and posterior (filled histogram) distribution for the accumulation rate $(\mathrm{yr} / \mathrm{cm})$, and the rightmost plots show the prior (curve) and posterior (filled histogram) for the dependence of accumulation rate between sections. The major plot shows the age distributions of calibrated 14C dates and the grey-scale age-depth model indicates precisely dated sections of the chronology in darker grey, while lighter grey areas indicate less precise sections. 


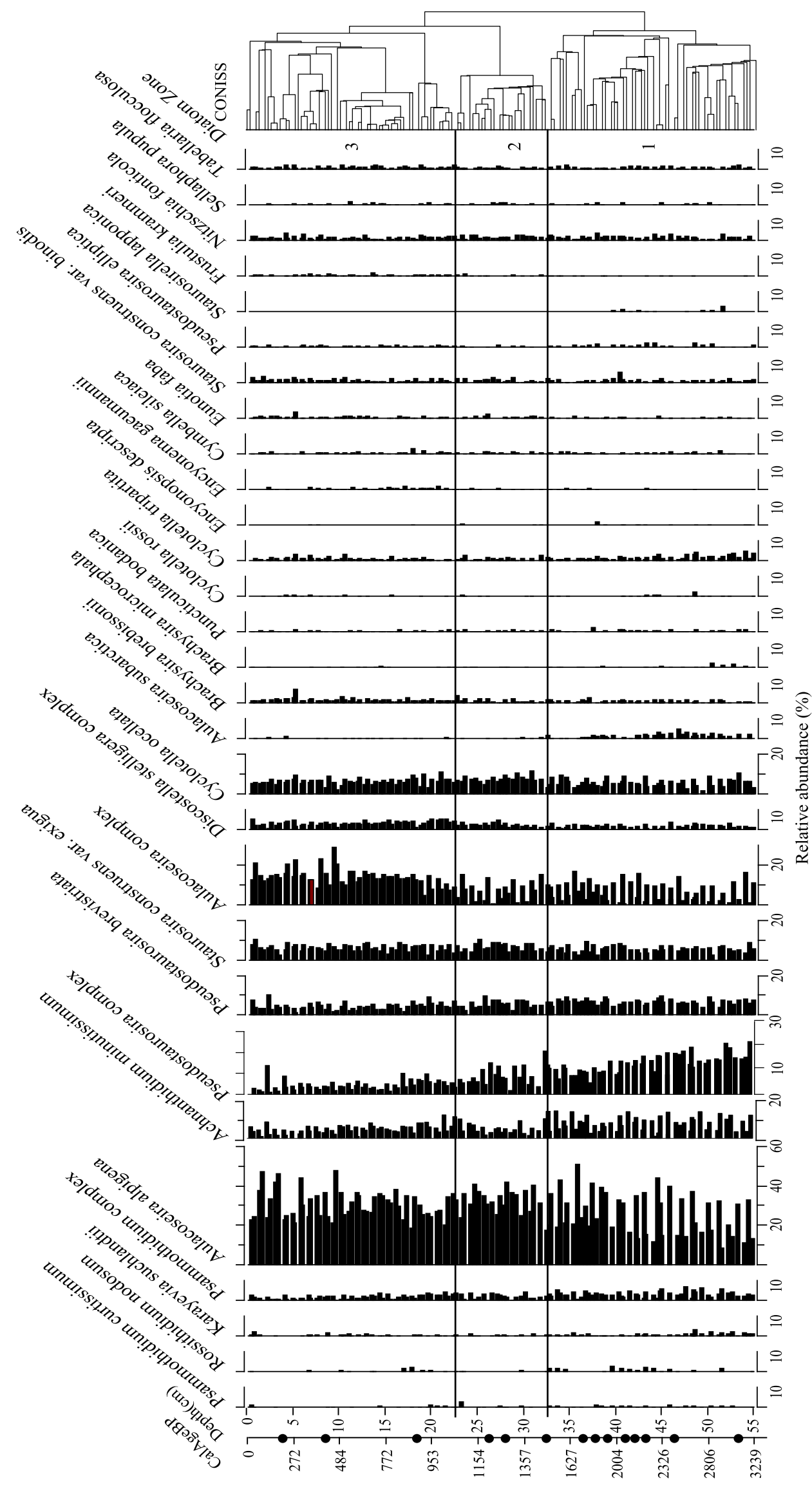

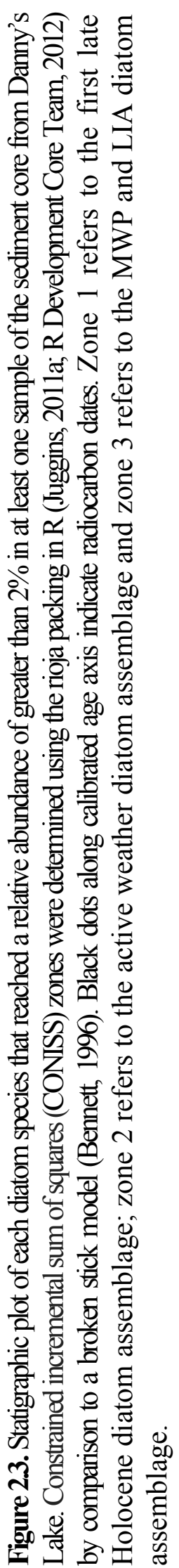




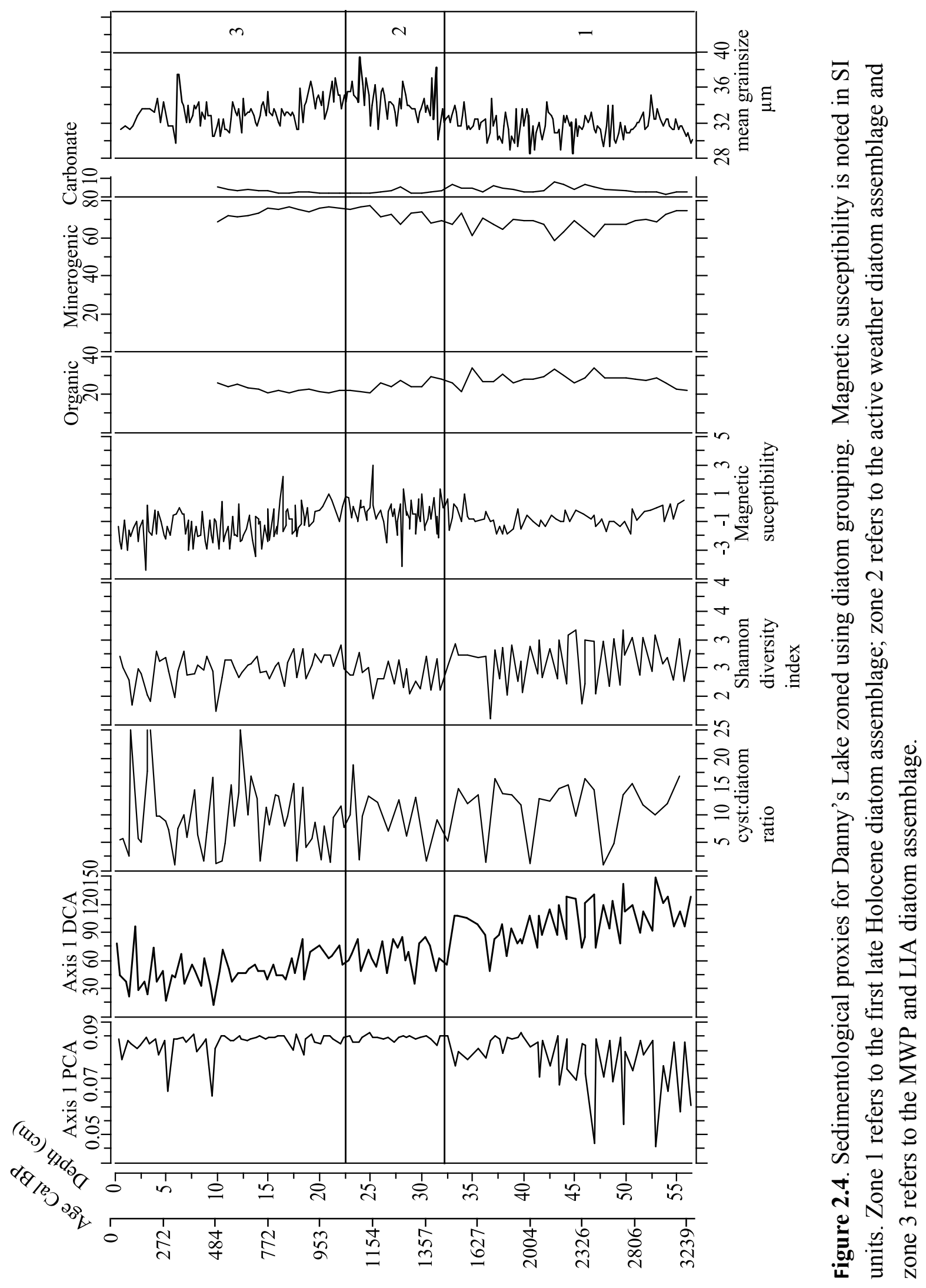


Table 2.1. Water chemistry variables taken at specified depths of Danny's lake in winter 2010 and summer 2011.

\begin{tabular}{|c|c|c|c|c|c|c|c|c|}
\hline \multirow[b]{2}{*}{$\begin{array}{l}\text { Depth } \\
\text { (m) }\end{array}$} & \multicolumn{2}{|c|}{$\begin{array}{c}\text { Dissolved oxygen } \\
\mathrm{mg} / \mathrm{L}\end{array}$} & \multicolumn{2}{|c|}{ Conductivity $(\mu \mathrm{S})$} & \multicolumn{2}{|c|}{ Temperature $\left({ }^{\circ} \mathrm{C}\right)$} & \multicolumn{2}{|c|}{$\mathrm{pH}$} \\
\hline & $\begin{array}{l}\text { Winter } \\
2010\end{array}$ & $\begin{array}{c}\text { Summer } \\
2011\end{array}$ & $\begin{array}{l}\text { Winter } \\
2010\end{array}$ & $\begin{array}{c}\text { Summer } \\
2011\end{array}$ & $\begin{array}{l}\text { Winter } \\
2010\end{array}$ & $\begin{array}{c}\text { Summer } \\
2011\end{array}$ & $\begin{array}{l}\text { Winter } \\
2010\end{array}$ & $\begin{array}{l}\text { Summer } \\
2011\end{array}$ \\
\hline 0 & 9.91 & 8.74 & 12.8 & 34.8 & 0.2 & 14.5 & 6.61 & 8.1 \\
\hline 0.5 & 13.03 & 8.68 & 22.7 & & 0.2 & & & \\
\hline 1 & 13.3 & 8.78 & 27.4 & & 0.2 & & & \\
\hline 1.5 & 14.47 & 8.98 & 27.4 & & 0.7 & & & \\
\hline 2 & 13.69 & 9.17 & 27 & & 1.2 & & & \\
\hline 2.5 & 13.11 & 9.17 & 27.1 & & 1.7 & & & \\
\hline 3 & 10.2 & 8.68 & 27.3 & & 2.1 & & & \\
\hline 3.5 & 7.68 & 8.55 & 27.4 & & 2.6 & & & \\
\hline 4 & 9.29 & 6.5 & 28.2 & 46.1 & 2.9 & 14.4 & & 8.2 \\
\hline 4.5 & 1.23 & & 32.8 & & 3.3 & & & \\
\hline
\end{tabular}


Table 2.2 Diatom species groupings included in stratigraphic diagram

\begin{tabular}{ll}
\hline Species Groupings & Comprising species \\
\hline Pseudostaurosira & $\begin{array}{l}\text { Staurosira construens var. venter } \\
\text { Staurosirella pinnata } \\
\text { Pseudostaurosira pseudoconstruens }\end{array}$ \\
Aulacoseira & Aulacoseira distans \\
& Aulacoseira lacustris \\
& Aulacoseira perglabra \\
Discostella stelligera & Discostella pseudostelligera \\
& Discostella stelligera \\
Psammothidium & Achnanthes levanderi \\
& Rossithidium pusillum
\end{tabular}


Table 2.3. Danny's Lake AMS radiocarbon results. $\delta 13 \mathrm{C}(\%)$ values were calculated relative to the VDPB standard, freshwater reservoir corrected dates were calibrated with IntCal09 (Reimer et al. 2009), and calibrated ranges presented represent a relative area of greater than 95\% (some values are composite). Outliers are shown in bold.

\begin{tabular}{|c|c|c|c|c|c|c|c|}
\hline \multirow{3}{*}{$\begin{array}{l}\begin{array}{l}\text { Lab ID } \\
\text { (UBA-) }\end{array} \\
17359\end{array}$} & \multirow{3}{*}{$\begin{array}{l}\begin{array}{l}\text { Depth } \\
\text { (cm) }\end{array} \\
5.7\end{array}$} & \multirow{3}{*}{$\begin{array}{l}\delta^{13} \mathrm{C} \\
(\%)\end{array}$} & \multicolumn{4}{|c|}{${ }^{14} \mathrm{C}$ age $\mathrm{BP}(1 \sigma)$} & \multirow{3}{*}{$\begin{array}{l}\text { Corr. cal BP } \\
(2 \sigma)\end{array}$} \\
\hline & & & \multicolumn{2}{|c|}{ Uncorrected } & \multicolumn{2}{|c|}{$\begin{array}{l}\text { Corrected } \\
\Delta \mathrm{R}=430\end{array}$} & \\
\hline & & & 693 & \pm 21 & 263 & \pm 21 & \\
\hline 17360 & 10.2 & -30.1 & 855 & \pm 23 & 425 & \pm 23 & $462-519$ \\
\hline 16543 & 15.0 & -26.3 & 1329 & \pm 23 & 899 & \pm 23 & $740-908$ \\
\hline 17361 & 21.9 & -29.2 & 1617 & \pm 25 & 1187 & \pm 25 & $1055-1177$ \\
\hline 17431 & 27.8 & -27.8 & 1659 & \pm 21 & 1229 & \pm 21 & $1072-1257$ \\
\hline 16544 & 32.6 & -27.5 & 1916 & \pm 25 & 1486 & \pm 25 & $1315-1408$ \\
\hline 20377 & 33.5 & -24.7 & 2071 & \pm 24 & 1641 & \pm 24 & $1419-1611$ \\
\hline 20378 & 34.2 & -27.8 & 2159 & \pm 24 & 1729 & \pm 24 & $1566-1703$ \\
\hline 17929 & 34.5 & -30.2 & 2257 & \pm 26 & 1827 & \pm 26 & $1700-1825$ \\
\hline 20376 & 35.3 & -29.5 & 2073 & \pm 28 & 1643 & \pm 28 & $1417-1614$ \\
\hline 20375 & 36.8 & -29.5 & 2248 & \pm 25 & 1818 & \pm 25 & $1697-1822$ \\
\hline 17432 & 37.6 & -29.0 & 2659 & \pm 32 & 2229 & \pm 32 & $2152-2335$ \\
\hline 20374 & 38.4 & -27.6 & 2392 & \pm 25 & 1962 & \pm 25 & $1865-1953$ \\
\hline 20373 & 39.3 & -29.1 & 2448 & \pm 33 & 2018 & \pm 33 & $1885-2059$ \\
\hline 17930 & 40.4 & -28.6 & 2549 & \pm 26 & 2119 & \pm 26 & $2002-2152$ \\
\hline 20371 & 41.4 & -28.7 & 2554 & \pm 28 & 2124 & \pm 28 & $2002-2154$ \\
\hline 20372 & 43.3 & -24.7 & 4863 & \pm 29 & 4433 & \pm 29 & $4877-5276$ \\
\hline 16545 & 45.0 & -29.1 & 2912 & \pm 24 & 2482 & \pm 24 & $2459-2717$ \\
\hline 16546 & 56.9 & -26.2 & 3604 & \pm 25 & 3174 & \pm 25 & $3361-3446$ \\
\hline 16547 & 70.1 & -29.6 & 5039 & \pm 51 & 4609 & \pm 51 & $5057-5471$ \\
\hline 16548 & 85.1 & -31.3 & 5834 & \pm 29 & 5404 & \pm 29 & $6180-6286$ \\
\hline 17931 & 89.5 & -29.6 & 6231 & \pm 34 & 5801 & \pm 34 & $6496-6674$ \\
\hline 16439 & 95.5 & -27.3 & 8112 & \pm 32 & 7682 & \pm 32 & $8412-8541$ \\
\hline 17932 & 99.1 & -28.9 & 7623 & \pm 38 & 7193 & \pm 38 & $7940-8111$ \\
\hline 16440 & 113.6 & -24.9 & 7450 & \pm 30 & 7020 & \pm 30 & $7792-7935$ \\
\hline
\end{tabular}




\title{
Chapter 3: Diatom Data Reveal Solar Forcing as a Late Holocene Climate Control in Canadian Subarctic
}

\author{
Dalton, $\mathrm{AS}^{\mathrm{a}}$; Macumber, $\mathrm{AL}^{\mathrm{a}}$; Patterson, $\mathrm{RT}^{\mathrm{a}}$; Swindles, $\mathrm{GT}^{\mathrm{b}}$; Roe, $\mathrm{HM}^{\mathrm{c}}$; Galloway, $\mathrm{JM}^{\mathrm{d}}$; \\ Falck, $\mathrm{H}^{\mathrm{e}}$
}

a. Ottawa-Carleton Geoscience Center, Department of Earth Sciences, Carleton University, Ottawa, Canada

b. School of Geography, University of Leeds, Leeds, United Kingdom

c. School of Geography, Archaeology and Palaeoecology, Queen's University of Belfast, Belfast, UK

d. Natural Resources Canada / Ressources naturelles Canada, Geological Survey of Canada / Commission geologique du Canada, Calgary, Alberta

e. Northwest Territories Geoscience Office, Yellowknife, Northwest Territories

\begin{abstract}
Here we present evidence of the influence of solar forcing on seasonal winter icecover at Danny's Lake, Northwest Territories, in the Canadian subarctic. This research is based on high-resolution time-series analysis of diatom assemblages from a 3300 cal. yr BP to present-day freeze core. Changes in the relative proportion of certain groups of diatom taxa have been demonstrated to provide an excellent proxy record of changes to seasonal ice-cover. As the duration of winter ice-cover in this region is primarily controlled by temperature, these diatom proxies also provide useful information on winter climate variability. We studied trends and cycles in the relative abundance of two species groups: (1) the heavily silicified Aulacoseira complex, a group of planktic diatom species that thrive in conditions of high turbulence, which keeps them suspended in the water
\end{abstract}


column; and (2) Pseudostaurosira complex, a group of benthic species that thrive under ice-cover conditions. Spectral analysis of changes in the relative abundance of these two diatom groups reveals statistically significant c. 89, 145 and 309-year cycles. Wavelet and cross-wavelet analysis of the diatom data resulted in the recognition of significant common power between diatom groups and total solar irradiance, suggesting that solar forcing plays a significant role in influencing year-over-year variation in ice-cover for this subarctic region. The c. 89 and 145 year cycles are attributed to the $90-140$ year upper band of the Gleissberg solar cycle, while the c. 309 year cycle is recognized as the 300 year harmonic of the 2115 year Hallstadt cycle. The record presented here is also characterized by the disappearance of all major diatom cycles during the Medieval Warm Period c. 1050 - c. 850 cal. yr BP and Roman Warm Period c. 1800 - c. 2200 cal yr BP which corresponds with a major reduction in total solar irradiance during these intervals. This paired breakdown of cyclicities in both total solar irradiance and diatom populations suggests that solar forcing plays a key role in determining temporal variation of diatom assemblages. These results are of interest to policy makers and planners as they assess the long-term viability of industrially important ice roads in the region, which are subject to the influence of not only possible anthropogenic warming, but to significant natural climate variability.

\section{Keywords}

late Holocene, diatoms, paleolimnology, wavelet analysis, spectral analysis, Gleissberg solar cycle, Northwest Territories, fresh water effect 


\section{Introduction}

With the retreat of the Laurentide Ice Sheet $\sim 9000$ years before present (yr BP) (Dyke and Prest, 1987), shallow lakes began to form on the exposed bedrock of the Canadian Shield, which covers a large portion of the Northwest Territories (NT), Canada. These arctic lakes are often located in catchments with little or no direct anthropogenic disturbance. The hydrology of these shallow lakes is strongly influenced by seasonal weather conditions (Adrian et al., 1999; Kohler \& Hoeg, 2000), thus their limnologic history provides a useful archive of regional climate variability (Smol et al., 2005). The treeline region of the subarctic is a particularly good indicator of climate change because organisms inhabiting this region often live close to the edge of their ecological tolerances (Macdonald et al., 1998; Pienitz et al., 1999; Rühland \& Smol, 2002; Lloyd et al., 2003; Seppa et al., 2003; Wolfe et al., 1996), and are thus sensitive to even the slightest climate variability (Lim et al., 2007).

Climate in the central NT became cooler but more stable during the late Holocene ( $\sim 3500 \mathrm{yr}$ BP - present-day), in part due to the development of relatively stable solar insolation at $65^{\circ} \mathrm{N}$ (Berger et al., 1991; Steinhilber et al., 2009). With the onset of the late Holocene, the treeline retreated southward to its modern-day position in the central NT (Karst-Riddoch et al., 2005; Rühland \& Smol, 2005; Miller et al., 2010). This long-term stability offers an opportunity to discern more subtle cyclical variations in natural climate. There have been a large number of paleolimnological papers carried out in region, which have utilized a variety of proxies, including diatoms, pollen and chironomids (Douglas et al., 1994; Cremer et al., 2001; Michelutti et al., 2003; Huang et al., 2004; Le Blanc et al., 2004; Fallu et al., 2005; Karst-Riddoch et al., 2005; Tammy et 
al., 2005; Finkelstein \& Gajewski, 2008, 2007; Lim et al., 2007; Rolland et al., 2008; MacDonald et al., 2009; Adams \& Finkelstein, 2010; Chakraborty et al., 2010; Clegg et al., 2010; Paul et al., 2010; Peros et al., 2010). However, the majority of these studies have not explored their results for trends and cycles, instead relying on proxy-based assemblage zoning to delineate data trends.

Changes in TSI influence the Earth's climate at annual, decadal, centennial, and millennial timescales (Bond et al., 2001; Wu et al., 2009; Gray et al., 2010). Solar forcing has been observed in many paleo-records as oscillatory patterns associated with an amplification of the well known 11-year Schwabe sunspot cycle (Peristykh and Damon, 2003). One such amplification, the Gleissberg cycle (Gleissberg, 1958), which has been observed in naked eye observations (Lean et al., 1995), is expressed at a lower band cycle of 50 - 80 years and an upper band cycle of 90 - 140 years. The Gleissberg cycle has been directly linked to solar sunspot activity, and has been widely reported in records spanning the last 12,000 years (Peristykh and Damon, 2003), as well as older records (Kern et al., 2012). Changes in TSI have also been shown to drive decadal-scale climate variability by means of teleconnections. For example, the relative positions of the Aleutian Low (AL) and North Pacific High (NPH) in the Northeast Pacific Ocean shift by more than $700 \mathrm{~km}$ through an 11-year sunspot cycle (Christoforou \& Hameed, 1997; Hameed \& Lee, 2005). Changes in the relative position of the AL and NPH result in cyclic weather and oceanic conditions in the Northeast Pacific (Patterson et al., 2013) that ultimately propagate inland towards the Danny's Lake study site (Porter et al., 2013).

Changes in solar variability have also been linked to changes in global temperature. For example, during the Maunder Minimum (c. 300 - c. 230 yr BP), the 
Schwabe sunspot cycle was nonexistent for several decades (Lean et al., 1995; Jones et al., 2001). This disruption resulted in a reduction in regional temperatures of $\sim 1{ }^{\circ} \mathrm{C}$ in the Canadian Arctic (D’Arrigo et al., 2009; Rolland et al., 2009). Conversely, warm periods in the Holocene have been linked to increased solar activity (e.g. Veizer, 2005), such as the increase TSI that corresponds with the Medieval Warm Period (MWP), Roman Warm Period (RWP), and the present-day Modern Maxima (Jirikowic \& Damon, 1994; Lean et al., 1995, Solanki et al., 2004). Changes in TSI have also been invoked to explain observed changes in many arctic proxy datasets, including Alaskan Holocene lake sediments (Hu et al., 2003), late Holocene glacier dynamics (Wiles et al., 2004), and a 700-year record of the linkage between solar forcing and boreal ecosystem response (Tinner et al., 2008).

Lake ice-cover in arctic regions impacts diatom (Class Bacillariophyceae) population assemblages by influencing habitat availability (Smol, 1988; Lotter \& Bigler, 2000). Since winter ice-cover duration is primarily controlled by temperature in this region, relative changes in past temperature can be inferred from diatom populations (Smol, 1988; Lotter \& Bigler, 2000). We focus on two key indicator groups, the Aulacoseira complex and the Pseudostaurosira complex. The Aulacoseira complex, which are panktic and require turbulene to thrive in the photic zone, is often used to infer changes in the influence of wind or precipitation on a lake (Korhola et al., 1996; Sorvari \& Korhola 1998). The Pseudostaurosira complex is a collection of benthic species that have the ability to flourish under ice-covered lake conditions (Smol, 1988).

This research was designed to determine whether there is a correlation between trends and cycles in the diatom assemblages at Danny's Lake and TSI variability. To test 
this hypothesis, we employed spectral and wavelet analysis on a 3300 year late Holocene record of variability in the Aulacoseira and Pseudostaurosira complexes. We also use cross-wavelet techniques to compare our diatom data to published TSI data. This research was made possible by the combined use of freeze coring, which provides an undisturbed sediment core, and a custom-designed sledge microtome (Macumber et al., 2011), which permitted for unprecedented sampling resolution.

This research has industrial applications for policy makers and planners concerned over the long-term viability of the Tibbitt to Contwoyto Winter Road (TCWR), NT, and other ice roads in the subarctic region. The $600 \mathrm{~km} \mathrm{TCWR,} \mathrm{which}$ spans from near Yellowknife in the south, north through the central NT and into southern Nunavut (Figure 3.1), is the world's longest heavy haul winter ice road, carrying more than $\$ 500$ million worth of critically needed supplies during a brief winter season to

mining operations. Any significant shortening of the ice road season would require construction of an expensive permanent road, which might impact the viability of existing and future mining operations. As the thermometer record for the region only extends back to 1947, there is a critical need for an understanding of not only the influence of possible anthropogenic warming, but also the nature of natural climatic trends and cycles (Kelly \& Wigley, 1992; Bond et al., 2001; Bard \& Frank, 2006).

\section{Site description and methodology}

\subsection{Danny's Lake, NT}

Danny's Lake $\left(63^{\circ} 28.547 \mathrm{~N} ;-112^{\circ} 32.785 \mathrm{~W}\right)$ is located in the present-day boreal forest region of the NT, Canada, approximately $150 \mathrm{~km}$ northeast of Yellowknife and 20 
$\mathrm{km}$ south of the modern-day treeline (Figure 3.1). Sparse vegetation presently surrounds the study site, comprised mainly of black spruce (Picea mariana) and white spruce (Picea glauca) with smaller amounts of tamarack (Larix larincina) and pine (Pinus L.) (Macumber et al., 2012). All lakes in the region overlay gneissic rocks of the Archean Slave craton (Davis et al., 1996). Climate in the Danny's Lake area is cold continental, with long, cold winters (average January temperature $-26.8^{\circ} \mathrm{C}$ ) and brief cool summers (average July Temperature $16.8^{\circ} \mathrm{C}$ ) (Environment Canada, 2013). Average annual precipitation is $164.5 \mathrm{~mm}$ (Environment Canada, 2013).

Danny's Lake has a surface area of $0.19 \mathrm{~km}^{2}$ (Figure 3.1) and maximum depth of $10 \mathrm{~m}$. A lake-water temperature profile collected in August 2011 revealed that the lake was unstratified with the surface temperature of $14.5^{\circ} \mathrm{C}$, nearly identical to the bottom temperature of $14.4^{\circ} \mathrm{C}$. The water budget for the lake is derived from a very small catchment, and mostly sourced from spring melt water that arrives at the lake as surface runoff across the discontinuous permafrost and minimal till cover in this region. Ephemeral streams at the north and south end of the lake are noted on maps, but were not observed during August 2011 (Figure 3.1). 


\subsection{Freeze coring and diatom procedure}

A $116.2 \mathrm{~cm}$ sediment core was retrieved from a $4.4 \mathrm{~m}$ sub-basin of Danny's Lake using a two-faced freeze coring device in March 2010 (Galloway et al., 2010; Macumber et al., 2012). The entire core was kept frozen and transported back to Carleton University where it was sub-sectioned into $1 \mathrm{~mm}$ samples using a custom-build sledge microtome (Macumber et al., 2011). Diatoms were enumerated every $0.5 \mathrm{~cm}$ until a depth of 56.3 cm. Diatom preparation and enumeration was conducted as per Dalton et al. (2013) in prep.

\subsection{Diatom groups chosen for spectral / wavelet analysis}

The diatom species groups Aualcoseira complex and Pseudostaurosira complex were dominant in the Danny's Lake sediment core (Dalton et al., 2013, in prep.) Aulacoseira complex and Pseudostaurosira complex made up an average of $40.8 \%$ $(\mathrm{sd}=9.30)$ and $22.8 \%(\mathrm{sd}=6.12)$ of total diatoms counted in each of the 120 sediment slices enumerated (Table 3.1). It has been previously shown that the relative amount of benthic (Pseudostaurosira complex) diatom population is indicative of the length of yearover-year ice-cover (Smol, 1988; Lotter \& Bigler, 2000). In addition, Aulacoseira complex are heavily silicified diatoms that require turbulence to stay in suspension in the photic zone (Reynolds, 1993), thus we interpret an increase in Aulacoseira complex as an increase in wind and/or precipitation (Korhola et al., 1996; Sorvari \& Korhola 1998). Since solar irradiance has been shown to effect lake biota both directly and indirectly via teleconnections, we decided to include both species groups in our time-series analysis. 
See Table 2.2 for a tally of which species comprise Aulacoseira complex and Pseudostaurosira complex, respectively.

Both diatom groups generated very high PCA1 and PCA 2 axis scores, representing 94.78 and $4.42 \%$ of the datasets variance, respectively (Table 1.1). Given the relative stability of the late Holocene period and the sensitivity of the subarctic to subtle climate change (Macdonald et al., 1998; Pienitz et al., 1999; Rühland \& Smol, 2002; Lloyd et al., 2003; Seppa et al., 2003; Wolfe et al., 1996), we assumed that variations in diatom populations reflect small-scale climate changes, such as those strongly influenced by changes in solar irradiance.

\subsection{Radiocarbon dating and age depth modelling}

Twenty-five bulk organic sediment samples were used for accelerator mass

spectrometry (AMS) ${ }^{14} \mathrm{C}$ dating at the ${ }^{14} \mathrm{CHRONO}$ Centre at Queen's University, Belfast. All samples underwent a standard hydrochloric acid wash to remove carbonate material. Radiocarbon ages were calibrated using Calib software version 6.1.0 (Stuiver \& Reimer, 1993) and the IntCal09 calibration curve (Reimer et al., 2009), with the addition of a 430 year fresh water effect. See Dalton et al. (2013), in prep for additional chronological methods on the Danny's Lake sediment core.

\subsection{Spectral and wavelet analysis}

Raw diatom data counts for Aulacoseira complex and Pseudostaurosira complex were converted to relative abundance and then standardized. Spectral analysis was carried out using REDFIT in the PAST software package (Hammer et al., 2001). Diatom time- 
series data were converted into the frequency domain using a Discrete Fourier transform and a null hypothesis test was used to assign statistical significance to the spectral peaks. A parametric approach was used to test the significance level of spectral peaks.

Wavelet analysis was carried out using the diatom data to explore the persistence and time of occurrence of significant frequencies throughout the paleorecord. Wavelet analysis was also conducted on TSI data from Steinhilber et al. (2009) for the past 3300 cal. yr BP. In order to align with TSI data, diatom data was interpolated to annual increments. A cross-wavelet transform of diatom data and reconstructed TSI time-series was carried out to identify and test the significance of common power using the Crosswavelet package in Matlab (Torrence \& Compo, 1998; Grinsted et al., 2004). The 95\% significance level against red noise is shown by the black contour.

\section{Results}

\subsection{Radiocarbon dating}

Of the twenty-five radiocarbon dates acquired from this sediment core (Table 3.1), seven outliers were identified using the general outlier model (Bronk Ramsey, 2009a) in OxCal version 4.1 (Bronk Ramsey, 2009b). A freshwater effect estimate of 430

years was then subtracted from all uncalibrated ${ }^{14} \mathrm{C}$ dates as described in Dalton et al. (2013) in prep. The average accumulation rate is $60 \mathrm{yr} / \mathrm{cm}$ for the upper $56.3 \mathrm{~cm}$ of the Danny's Lake core, and since samples were taken at $0.5 \mathrm{~cm}$ intervals, 60 is also the average Nyquist Frequency. In paleoclimate studies, the Nyquist frequency is double the temporal sampling resolution, and describes the limit to what cycles can be resolved given the sampling resolution and age model (Davis, 1986). 


\subsection{Spectral analysis}

The Aulacoseira complex and Pseudostaurosira complex display similar significant (95\%) spectral peaks; spanning 141 - 148 years for Aulacoseira complex, and 141 - 154 years for Pseudostaurosira complex (Figure 3.3). For simplicity purposes, these cyclicities will be referred to as c. 145 . A significant $(95 \%)$ c. 89 year cycle was detected solely in the Aulacoseira complex data, and another significant (95\%) c. 309 year cycle was observed in Pseudostaurosira complex results. Of additional interest are the very similar c. 63 year and c. 68 year cycles that were observed in the respective Aulacoseira complex and Pseudostaurosira complex spectral results. As they were slightly below the $95 \%$ confidence interval they are not considered further. Similarly, at the significant $99 \%$ confidence interval, we observed a c. 54 year cycle peak in the Pseudostaurosira complex spectral results. Again, we cannot consider this peak further as the wavelength fell just short of the statistically significant 60 year Nyquist frequency.

\subsection{Wavelet analysis}

The dominant c. 145-year frequency span identified in both diatom species is prominent between c. 1800 - c. 1200 cal. yr BP and c. 2700 - c. 2400 cal. yr BP in Pseudostaurosira complex and between c. 1800 - c. 1200 cal. yr BP and c. 2700 - c. 2200 cal. yr BP in Aulacoseira complex The c. 89 year cycle of Aulacoseira complex occurs between c. 600 - c. 300 cal. yr BP, c. 1650 - c. 1200 cal. yr BP and between c. 2500 - c. 2250 cal. yr BP (Figure 3.4). A 309 year cycle within the Pseudostaurosira complex occurs through a significant part of the record between c. 2800 - c. 550 cal. yr BP. 


\subsection{Cross-wavelet analysis}

The cross-wavelet transforms show that both Aulacoseira complex and Pseudostaurosira complex abundances show significant non-stationary common power at c. 89 years with TSI through the entire record (Figure 3.5). The relationship is particularly strong between c. $600 \mathrm{cal}$. yr BP to present, with a pronounced but shortlived breakdown at this cycle bandwidth for both groups between at c. 400 cal. yr BP (Figure 3.5). A similar pattern of common power as was observed after c. 600 cal yr BP is prevalent between c. 1800 - c. 1100 cal. yr BP and again from c. 3000 - c. 2200 cal. yr BP. A c. 145 year bandwidth cycle is also apparent between c. 3200 - c. 2200 cal. yr BP for Aulacoseira complex and TSI. In addition, a very strong c. 309 year common power between Pseudostaurosira complex and TSI is prevalent between c. 1450 - c. 1050 cal. yr BP. There is a near complete breakdown between the diatom complex groups and TSI between c. 600 - 1100 cal. yr BP and c. 1800 - c. 2200 cal. yr BP.

\section{Discussion}

The strong common power between diatom populations and TSI support the hypothesis that solar variability has been a key driver of climate, ice-cover and lake hydrology in the Canadian Subarctic through the late Holocene (Figure 3.5). Based on the resolution of the results presented here, TSI influence of climate is responsible for significant short-term climate dynamics in this region from decadal to centennial scales. 


\subsection{Gleissberg cycle}

The c. 89 and c. 145 year cycles detected in Aulacoseira complex and Pseudostaurosira complex correspond to the upper band $(90-140$ years $)$ of the Gleissberg solar cycle (Ogurtsov et al., 2002). Weather in this region of the NT spawns from the northeast Pacific Ocean (Pienitz et. al, 1999; Hu et al., 2003), where solar irradiance has been previously shown to drive decadal-scale climate by means of controlling the relative position of the AL and NPH (Christoforou \& Hameed, 1997; Hameed \& Lee, 2005). This ocean teleconnection has been previously detected in treerings from the boreal NT region (Porter et al., 2013), as well as late Holocene glacier

advance (Wiles et al., 2004) and temperature anomalies in Alaska (Papineau, 2001). Furthermore, dynamics of the AL have been shown to drive moisture shifts in the Yukon (Anderson et al., 2005).

We detect a c. 89 year cycle uniquely in Aulacoseira complex throughout the late Holocene period, and this frequency demonstrates common power to the TSI record of Danny's Lake. Aulacoseira complex are heavily silicified diatoms that require turbulence to stay in suspension in the photic zone (Reynolds, 1993), thus we interpret an increase in Aulacoseira complex as an increase in wind and/or precipitation (Korhola et al., 1996; Sorvari \& Korhola, 1998). Given the teleconnection mechanism described above, we suggest that these changes in Aulacoseira complex are the result of increased wind and/or precipitation, ultimately caused by changes in TSI.

The c. 145 year cycle detected in both Aulacoseira complex and Pseudostaurosira complex time-series falls within the upper frequency band of the Gleissberg cycle 
(Ogurtsov et al., 2002). The response of Aulacoseira complex can be explained as an increase in wind and/or precipitation resulting from the teleconnections between TSI and Pacfic Ocean pressure gyres. A study of ocean sediments from Effingham Inlet, British Columbia, found similar c. 135 year cycles in sediment deposition spanning the last 4500 years (Patterson et al., 2004), which hints at solar-driven Pacific Ocean dynamics as described above.

The mechanism for the c. 145 year solar cycle observed in Pseudostaurosira complex cannot be explained via increased precipitation from ocean teleconnections. Pseudostaurosira complex are benthic species that thrive in ice-cover conditions, therefore we suggest that a short-lived decrease in temperature, and resulting increase in year-over-year ice-cover, must be responsible for this periodicity. Changes in TSI have previously been linked to changes in temperature. For example, the Maunder Minimum, MWP, RWP and the present-day Modern Maxima all correspond to changes in TSI (Jirikowic \& Damon, 1994; Lean et al., 1995, Solanki et al., 2004). Therefore, rather than being indirectly impacted by solar radiation via ocean teleconnections, we suggest that the Pseudostaurosira complex is being directly influenced by incoming TSI at Danny's Lake. We suggest that variability in TSI causes changes to regional temperature, which impacts year-over-year ice cover, and therefore diatom populations.

Regardless of whether the Aulacoseira complex and Pseudostaurosira complex are responding to pure solar irradiation or secondary effects of solar irradiation through teleconnections from the Pacific Ocean, diatoms and TSI share common power throughout a significant portion of the analyzed record. However, all cycles completely disappeared from both diatom records between c. 1200 - c. 600 cal. yr BP and c. $2200-$ 
c. 2000 cal. yr BP (Figure 3.3). Periodicities in TSI also broke down during these intervals, although the overall TSI levels increased (Steinhilber et al., 2009). These periods correspond to the MWP, where average temperatures rose in this region from $\sim 10^{\circ} \mathrm{C}$ at c. $1540 \mathrm{yr} \mathrm{BP}$ to $\sim 12^{\circ} \mathrm{C}$ by c. $800 \mathrm{yr}$ BP (Upiter et al., 2013) and the RWP, associated with an increase in temperature similar to that observed during the Hypsithermal (Perner et al., 2012). This paired breakdown of both diatom and TSI cycles further corroborate our suggestion that solar irradiance is a key driver of climate in this region of the subarctic.

\subsection{Hallstadt cycle}

A significant c. 309 year cycle was detected in the Pseudostaurosira complex. This correlates with the c. 300 year harmonic of the 2115-year Hallstadt cycle (Damon \& Jirikowic, 1992). A similar band of cycles was detected in the NE Pacific where c. 300 year cycles observed in a record of annually deposited laminated couplets, was attributed to solar forcing (Patterson et al., 2004). They attributed their record to solar derived teleconnections originating in the tropics. Previous research has documented the significant influence of climate teleconnections originating from the Pacific on climate in the NT (Porter et al., 2013), thus the presence of similar cycles in Holocene records from the two regions is not unexpected.

\section{Implications}

Results from this research have both regional and broader implications. Solar cycles have persisted throughout geologic history (Dean \& Schwalb, 2000; Peristykh \& Damon, 2003; Kern et al., 2012), and have been linked to climate forcing worldwide (Wu 
et al., 2009). Both Aulacoseira complex and Pseudostaurosira complex share significant common power with TSI at various non-stationary cycle bandwidths through the entire late Holocene. This commonality indicates that changes in solar irradiance have had an important influence on climate and seasonal lake ice cover throughout this time period. TSI levels are presently very high when compared against earlier intervals in the late Holocene (Solanki et al., 2004; Usoskin et al., 2004; Roth \& Jutes, 2013). Based on evidence linking other Holocene warm periods to increased solar activity (Veizer, 2005), it is therefore not surprising that we see present day warming. Since variations in TSI significantly influence the energy balance of the Earth, particularly at high latitudes (Veizer, 2005; Jungclaus et al. 2010) cyclicity in solar forcing is a dominant force in determining seasonal ice duration on high-latitude lakes. Our results have important implications for policy makers and planners regarding the future viability of the TCWR. Although the threat of anthropogenic-derived warming in arctic regions is of concern, the ability to recognize climate cycles that are governed by predictable variation in solar irradiance is important.

\section{Conclusions}

Trends and cycles in the relative abundance of Aulacoseira complex and Pseudostaurosira complex populations were analyzed from a freeze core from Danny's Lake, NT. Spectral analysis revealed statistically significant 89 , c. 145 and 309 year cycles. Wavelet and cross-wavelet analysis of the diatom data indicated that these cycles were non-stationary and that they displayed significant common power with TSI. We suggest that solar forcing plays a significant role in influencing year-over-year variation in ice-cover in this subarctic region. The c. 89 and c. 145 year cycles are attributed to the 
90 - 140 year upper band of the Gleissberg solar cycle, while the 309 year cycle is attributed to the 300 year harmonic of the 2115 year Hallstadt cycle. These results are of interest to policy makers and planners of the TCWR, which is subject to the influence of possible anthropogenic warming and also to significant natural climate variability.

\section{Acknowledgements}

Financial support for the "Paleoclimatological assessment of the central NT: Implications for the long-term viability of the Tibbitt to Contwoyto Winter Ice Road" project was provided by the Natural Sciences and Engineering Research Council of Canada (NSERC), the Geological Survey of Canada, the Northwest Territories Geoscience Office, the North Slave Métis Alliance, and the Tibbitt to Contwoyto Winter Road Joint Venture. We acknowledge the support of the Polar Continental Shelf Program (PCSP) and Northern Scientific Training Program (NSTP), as well as grants provided by Northwest Territories Cumulative Impact Monitoring Program (CIMP) to JMG and HF. We would also like to thank the Northwest Territories Geosciences Office (NTGO) for their support, fieldwork help and wealth of knowledge on the Yellowknife Region.

In addition, we are indebted to the staff of the Tibbitt to Contwoyto Winter Road Joint Venture who provided logistical support for field-work in this challenging region. Staff provided valuable knowledge and assisted in sediment core collection. We thank Robert Mercredi of the North Slave Métis Alliance for assistance in core collection. 


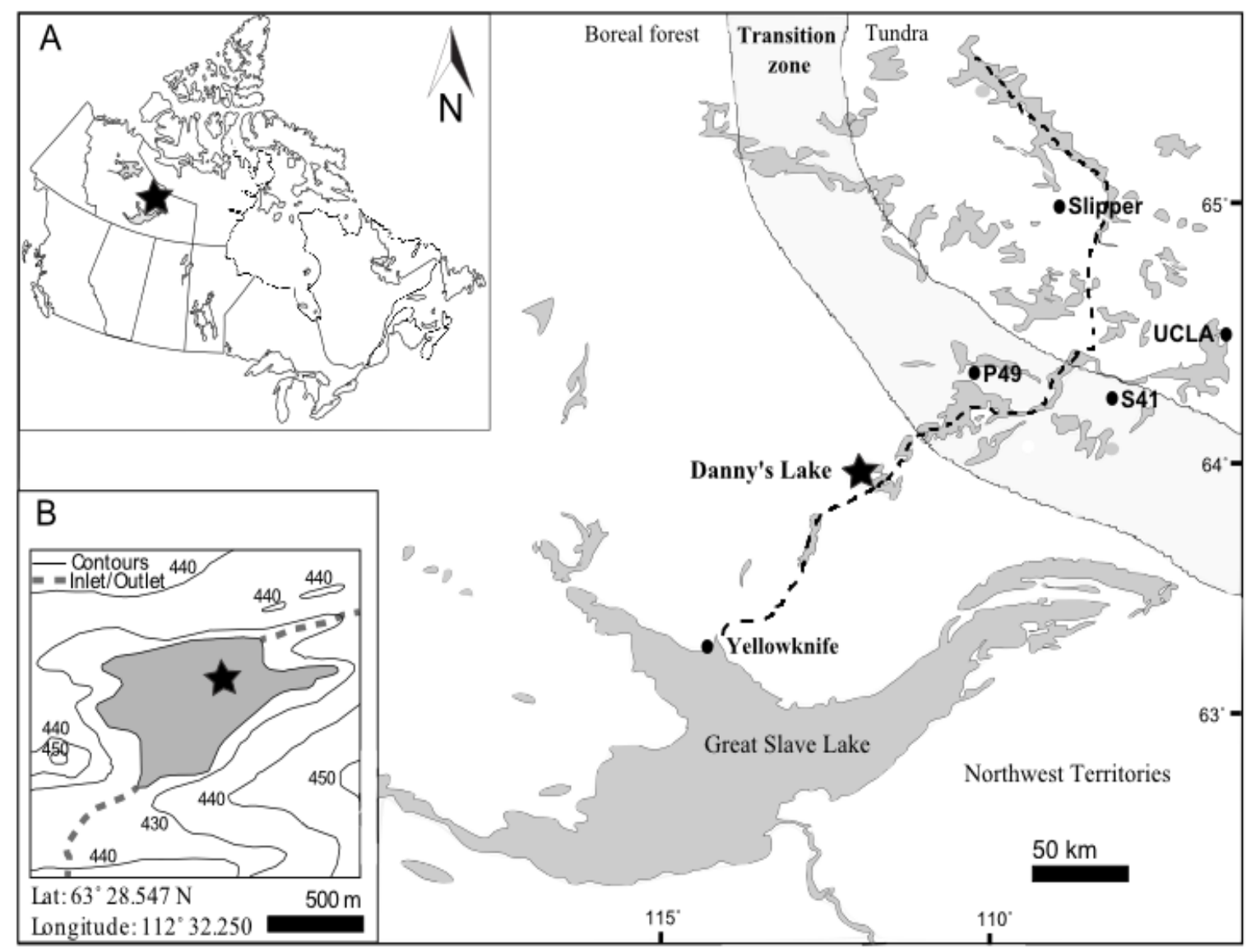

Figure 3.1 Location of Danny's Lake. Inset showing location the region (A) and of coring site (B), as denoted by the star. Other sites including Slipper Lake, Lake P-49, UCLA Lake and Lake S41 are also marked. The dashed line indicates the position of the Tibbitt to Contwoyto Winter Road. The relative position of boreal to tundra transition is also shown. 

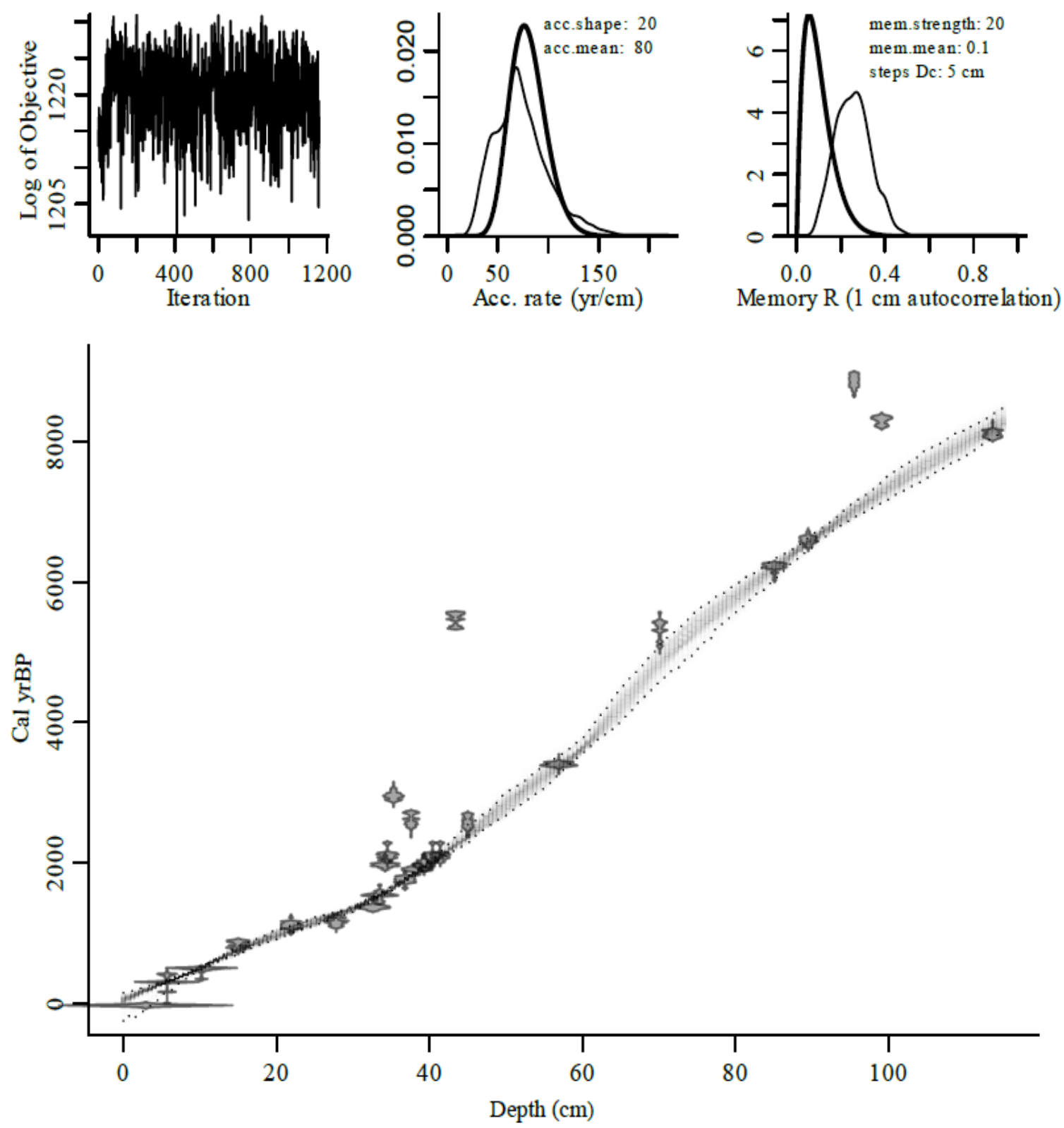

Figure 3.2. Bayesian age-depth model for Danny's Lake. On the top panel, the leftmost plot shows that the Markov Chain Monte Carlo runs were stable (1200 iterations), the middle plot shows the prior (curve) and posterior (filled histogram) distribution for the accumulation rate $(\mathrm{yr} / \mathrm{cm})$, and the rightmost plots show the prior (curve) and posterior (filled histogram) for the dependence of accumulation rate between sections. The major plot shows the age distributions of calibrated 14C dates and the grey-scale age-depth model indicates precisely dated sections of the chronology in darker grey, while lighter grey areas indicate less precise sections. 

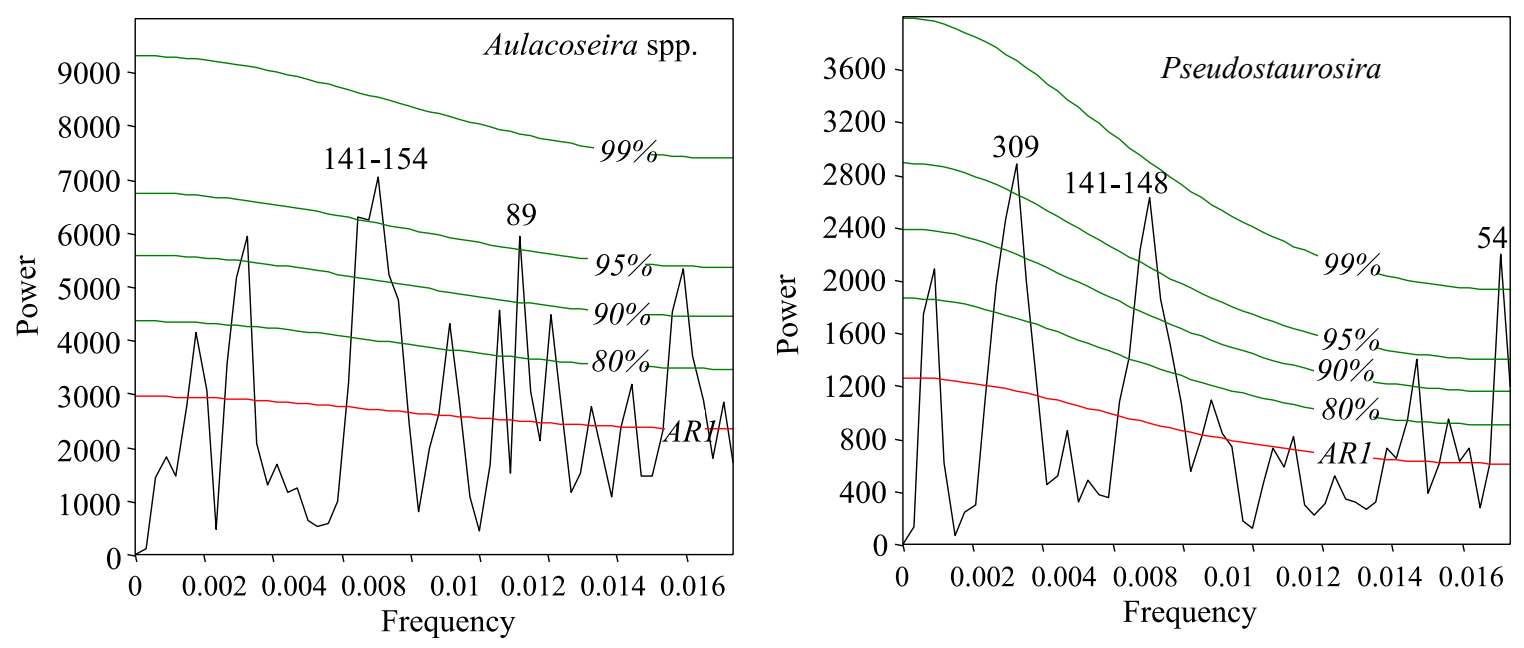

Figure 3.3. REDFIT spectral analysis results for Aulacoseira complex and Pseudostaurosira complex Only peaks surpassing the 95\% confidence interval are statistically significant. 


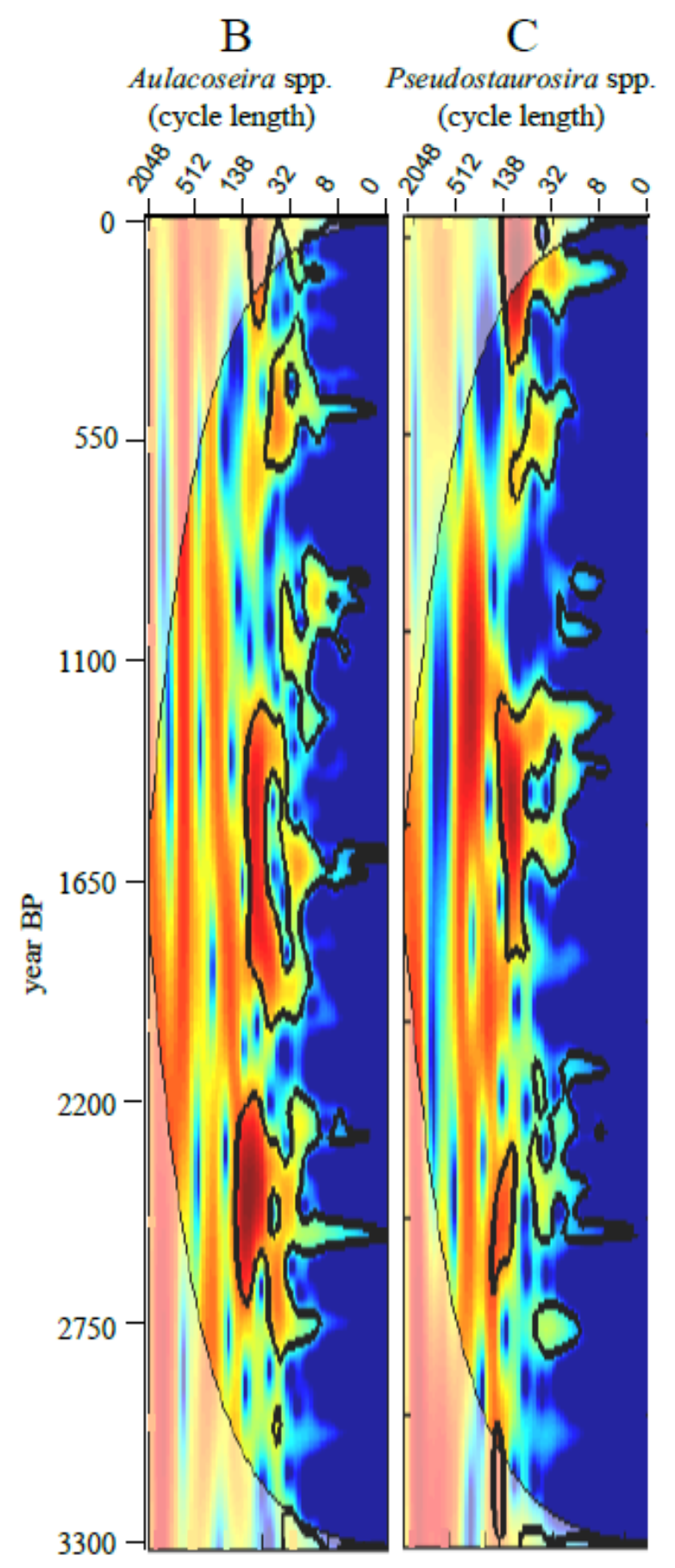

Figure 3.4. Wavelet results for Aulacoseira complex and Pseudostaurosira complex Wavelet scalograms show cycle strength and persistence during the time period. High values (red color) are assigned to areas where the indicated cycle is persistent. Low values (blue color) indicate lack of cyclicity at the given wavelength and time period, and dashed line indicates the cone of influence. Black line is $95 \%$ significance against red noise background 


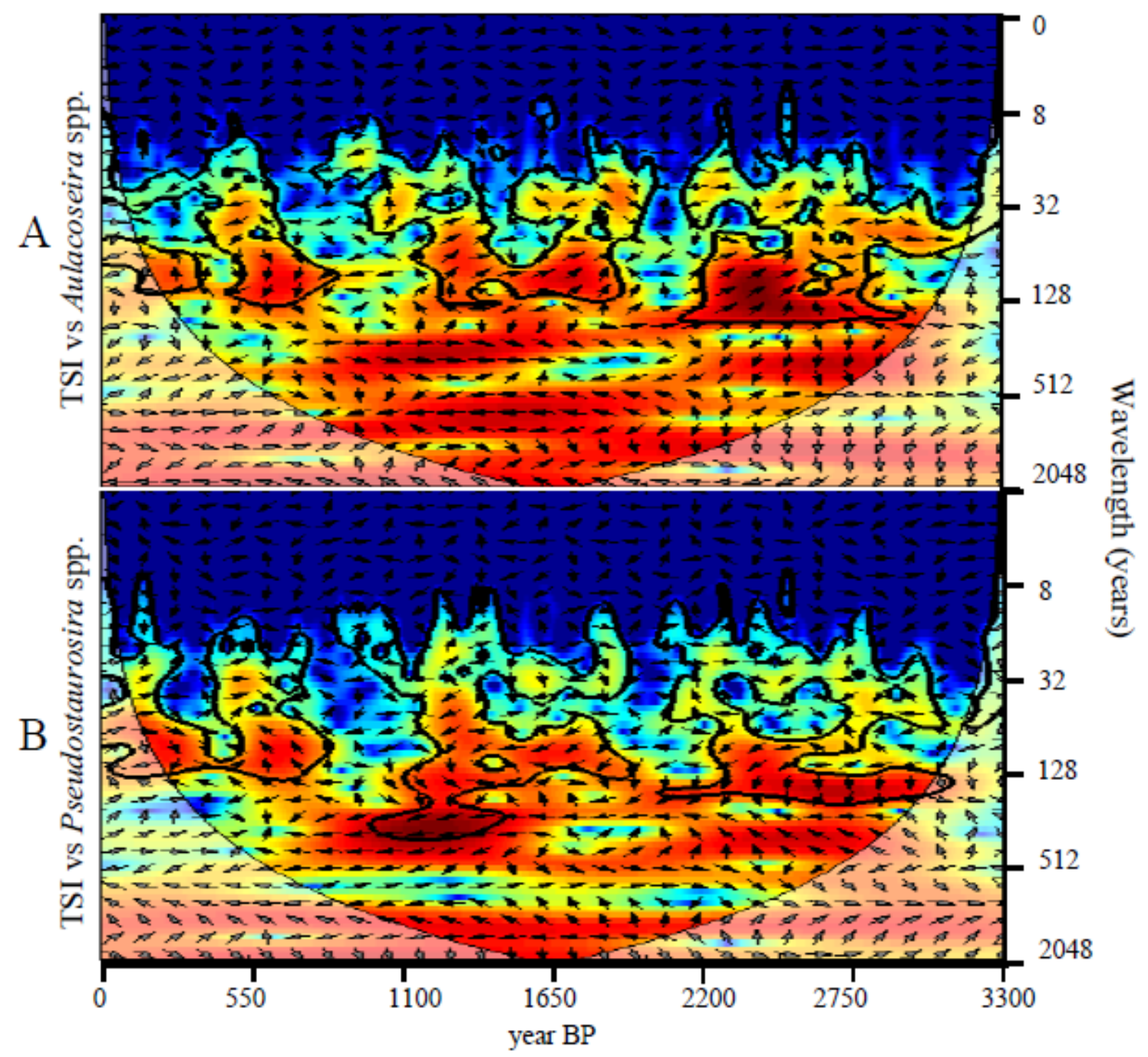

Figure 3.5. Cross-wavelet analysis for TSI and Aulacoseira complex (A); TSI and Pseudostaurosira complex (B). Vertical arrows indicate that one variable is leading the other. 95\% significance level against red noise is shown as a thick contour. Arrows included are purported to indicate causality between TSI and diatoms. An arrow pointing upwards indicates that TSI is leading while an arrow downwards indicates that diatom species groups are leading. Horizontal arrows indicate in phase (arrow pointing right) or anti-phase (arrow point left) relationships between TSI and diatom species groups. Caution must be taken when interpreting phase relationships, as the slightest offset in the TSI or diatom age model may cause issues with causality. 
Table 3.1. Summary of downcore relative abundance values and PCA axis for Aulacoseira complex and Pseudostaurosira complex

\begin{tabular}{|c|c|c|c|c|c|c|}
\hline & Maximum & Minimum & Mean & $\begin{array}{l}\text { St } \\
\text { Dev }\end{array}$ & $\begin{array}{l}\text { PCA Axis } 1 \\
\text { Score }\end{array}$ & $\begin{array}{l}\text { PCA Axis } 2 \\
\text { Score }\end{array}$ \\
\hline $\begin{array}{l}\text { Pseudostaurosira } \\
\text { complex }\end{array}$ & 38.63 & 10.82 & 22.86 & 6.12 & 190.62 & 87.352 \\
\hline $\begin{array}{l}\text { Aulacoseira } \\
\text { complex }\end{array}$ & 69.47 & 16.63 & 40.84 & 9.30 & 405.84 & -47.144 \\
\hline
\end{tabular}


Table 3.2. Radiocarbon results for Danny's Lake. $\delta^{13} \mathrm{C}(\%)$ values were calculated relative to the VDPB standard, freshwater reservoir corrected dates were calibrated with IntCal09 (Reimer et al. 2009), and calibrated ranges presented represent a relative area of greater than $95 \%$ (some values are composite). Outliers are shown in bold.

\begin{tabular}{|c|c|c|c|c|c|c|c|}
\hline \multirow{3}{*}{$\begin{array}{l}\begin{array}{l}\text { Lab ID } \\
(\text { UBA-) }\end{array} \\
17359\end{array}$} & \multirow{3}{*}{$\begin{array}{l}\begin{array}{l}\text { Depth } \\
(\mathrm{cm})\end{array} \\
5.7\end{array}$} & \multirow{3}{*}{$\begin{array}{l}\delta^{13} \mathrm{C} \\
(\%)\end{array}$} & \multicolumn{4}{|c|}{${ }^{14} \mathrm{C}$ age $\mathrm{BP}(1 \sigma)$} & \multirow[b]{2}{*}{$\begin{array}{l}\text { Corr. cal BF } \\
(2 \sigma)\end{array}$} \\
\hline & & & \multicolumn{2}{|c|}{ Uncorrected } & \multicolumn{2}{|c|}{$\begin{array}{l}\text { Corrected } \\
\Delta R=430\end{array}$} & \\
\hline & & & 693 & \pm 21 & 263 & \pm 21 & $284-424$ \\
\hline 17360 & 10.2 & -30.1 & 855 & \pm 23 & 425 & \pm 23 & $462-519$ \\
\hline 16543 & 15.0 & -26.3 & 1329 & \pm 23 & 899 & \pm 23 & $740-908$ \\
\hline 17361 & 21.9 & -29.2 & 1617 & \pm 25 & 1187 & \pm 25 & $1055-1177$ \\
\hline 17431 & 27.8 & -27.8 & 1659 & \pm 21 & 1229 & \pm 21 & $1072-1257$ \\
\hline 16544 & 32.6 & -27.5 & 1916 & \pm 25 & 1486 & \pm 25 & $1315-1408$ \\
\hline 20377 & 33.5 & -24.7 & 2071 & \pm 24 & 1641 & \pm 24 & $1419-1611$ \\
\hline 20378 & 34.2 & -27.8 & 2159 & \pm 24 & 1729 & \pm 24 & $1566-1703$ \\
\hline 17929 & 34.5 & -30.2 & 2257 & \pm 26 & 1827 & \pm 26 & $1700-1825$ \\
\hline 20376 & 35.3 & -29.5 & 2073 & \pm 28 & 1643 & \pm 28 & $1417-1614$ \\
\hline 20375 & 36.8 & -29.5 & 2248 & \pm 25 & 1818 & \pm 25 & $1697-1822$ \\
\hline 17432 & 37.6 & -29.0 & 2659 & \pm 32 & 2229 & \pm 32 & $2152-2335$ \\
\hline 20374 & 38.4 & -27.6 & 2392 & \pm 25 & 1962 & \pm 25 & $1865-1953$ \\
\hline 20373 & 39.3 & -29.1 & 2448 & \pm 33 & 2018 & \pm 33 & $1885-2059$ \\
\hline 17930 & 40.4 & -28.6 & 2549 & \pm 26 & 2119 & \pm 26 & $2002-2152$ \\
\hline 20371 & 41.4 & -28.7 & 2554 & \pm 28 & 2124 & \pm 28 & $2002-2154$ \\
\hline 20372 & 43.3 & -24.7 & 4863 & \pm 29 & 4433 & \pm 29 & $4877-5276$ \\
\hline 16545 & 45.0 & -29.1 & 2912 & \pm 24 & 2482 & \pm 24 & $2459-2717$ \\
\hline 16546 & 56.9 & -26.2 & 3604 & \pm 25 & 3174 & \pm 25 & $3361-3446$ \\
\hline 16547 & 70.1 & -29.6 & 5039 & \pm 51 & 4609 & \pm 51 & $5057-5471$ \\
\hline 16548 & 85.1 & -31.3 & 5834 & \pm 29 & 5404 & \pm 29 & $6180-6286$ \\
\hline 17931 & 89.5 & -29.6 & 6231 & \pm 34 & 5801 & \pm 34 & $6496-6674$ \\
\hline 16439 & 95.5 & -27.3 & 8112 & \pm 32 & 7682 & \pm 32 & $8412-8541$ \\
\hline 17932 & 99.1 & -28.9 & 7623 & \pm 38 & 7193 & \pm 38 & $7940-8111$ \\
\hline 16440 & 113.6 & -24.9 & 7450 & \pm 30 & 7020 & \pm 30 & $7792-7935$ \\
\hline
\end{tabular}




\section{Chapter 4: Conclusions}

This research is part of a much larger project with the mandate to determine how climate in the boreal region of the Northwest Territories (NT) has varied over the past $3500 \mathrm{yr}$ BP. With a focus on high-resolution sampling, this research has revealed important information about past climate variability in the boreal region of the NT. Chapter 2 utilizes diatom populations in Danny's Lake, to discern climate trends in this region over the late Holocene. The diatom record for this time period shows that climate has been fairly stable over the past 3330 cal. yr BP, although subtle shifts in diatom assemblages suggest small-scale climate changes. In the first late Holocene period (3330 - 1480 cal. yr BP), there were cool, windy conditions. This is evidenced by the high Pseudostaurosira complex, which thrive under conditions of increased ice-cover, along with low Aulacosiera complex, which require turbulent lake conditions to thrive in the photic zone. From 1480 - 1090 cal. yr BP, there is evidence for period of active weather, evidenced by a decrease in benthic Achnanthidium minutissimum, an increase in sediment grain size, and significant fluctuations in the magnetic susceptibility data through this interval. Finally, the dominance of planktic Aulacoseira complex populations after 960 cal. yr BP suggests a stable Little Ice Age climate, which appears to persist into presentday at this site. Chapter 3 is the first study to examine two Aulacoseira complex and Pseudostaurosira complex diatom groups from a shallow Canadian subarctic lake to determine solar influence on climate over the late Holocene period. Spectral analysis of changes in the relative abundance of these two diatom groups reveals statistically significant c. 89,145 and 309 year cycles, which correspond well with total solar 
irradiance (TSI) over the late Holocene, suggesting a link between TSI and diatom populations in the subarctic.

Previous to this Danny's Lake research, chironomids were used to reconstruct past temperatures at Lake P-49, located along the Tibbitt to Contwoyto Winter Road (TCWR). In addition, there are currently several multi-proxy research projects underway on lake sediment cores spanning the TCWR. Modern day-surface sediments are also being analyzed to determine how environmental parameters impact lake biota, which can then be used to create training sets for downcore temperature and environmental inferences. With the continuation of mining in the NT, accurate forecasting of future climate is of utmost importance for policy planners. Results from this dissertation are of interest to policy makers and planners as they assess the long-term viability of industrially important ice roads in the region, which are subject to the influence of not only possible anthropogenic warming, but to significant natural climate variability. 


\section{References}

Abbott, M., Stafford, T., 1996. Radiocarbon geochemistry of modern and ancient arctic lake systems, Baffin Island, Canada. Quaternary Research 45, 300-311.

Academy of Natural Sciences and collaborators, 2011. ANSP/NAWQA/EPA 2011 diatom and non-diatom taxa names. Names of algae taxa used beginning August 2011 for analysis of samples collected by USGS NAWQA, EPA NARS, and ANSP PCER projects. Available: http://diatom.ansp.org/nawqa/Taxalist.aspx

ACIA, 2004. Impacts of a Warming Arctic: Arctic Climate Impact Assessment. Cambridge, UK.

Adams, J., Finkelstein, S., 2010. Watershed-scale reconstruction of middle and late Holocene paleoenvironmental changes on Melville Peninsula, Nunavut, Canada. Quaternary Science Reviews 29, 2302-2314.

Adrian, R., Walz, N., Hintze, T., Hoeg, S., Rusche, R., 1999. Effects of ice duration on plankton succession during spring in a shallow polymictic lake. Freshwater Biology $41,621-634$.

Anderson, L., Abbott, M.B., Finney, B.P., Edwards, M.E., 2005. Palaeohydrology of the Southwest Yukon Territory, Canada, based on multiproxy analysis of lake sediment cores from a depth transect. Holocene 15, 1172-1183

Anderson, R., 1982. A long geoclimatic record from the Permian. Journal of Geophysical Research 87, 7285-7294.

Bard, E., Frank, M., 2006. Climate change and solar variability: What's new under the sun? Earth and Planetary Science Letters 248, 1-14.

Barnekow, L., Possnert, G., Sandgren, P., 1998. AMS 14C chronologies of Holocene lake sediments in the Abisko area, northern Sweden - a comparison between dated bulk sediment and macrofossil samples. GFF 120, 59-67.

Barnese, L., Lowe, R., 1992. Effects of Substrate, Light, and Benthic Invertebrates on Algal Drift in Small Streams. Journal of the North American Benthological Society $11,49-59$.

Bennett, K.D., 1996. Determination of the number of zones in a biostratigraphical sequence. New Phytologist 132, 155-170.

Berger, A., Loutre, M.F., Lema, D.G.G., Cyclotron, C., Louvam-la-neuve, B.I., 1991. Insolation values for the climate of the last 10 million years 10, 297-317. 
Berner, K., Koc, N., Godtliebsen, F., 2010. High frequency climate variability of the Norwegian Atlantic Current during the Holocene period and a possible connection to the Gleissberg cycle. The Holocene 20, 245-255.

Blaauw, M., Christen, J., 2011. Flexible Paleoclimate Age-Depth Models Using an Autoregressive Gamma Process. Bayesian Analysis 6, 457-474.

Blaauw, M., van Geel, B., Kristen, I., Plessen, B., Lyaruu, A., Engstrom, D.R., van der Plicht, J., Verschuren, D., 2011. High-resolution 14C dating of a 25,000-year lakesediment record from equatorial East Africa. Quaternary Science Reviews 30, 30433059.

Blott, S., Pye, K., 2001. Gradistat: A grain-size distribution and statistics package for the analysis of unconsolidated sediments. Earth Surface Processes and Landforms 26, $1237-1248$.

Bond, G., Kromer, B., Beer, J., Muscheler, R., Evans, M., Showers, W., Hoffman, S., Lotti-Bond, R., Hajdas, I., Bonani, G., 2001. Persistent solar influence on North Atlantic climate during the Holocene. Science 294, 2130-2136.

Bronk Ramsey, C., 2009a. Dealing with outliers and offsets in radiocarbon dating. Radiocarbon 51, 1023-1045.

Bronk Ramsey, C., 2009b. Bayesian analysis of radiocarbon dates. Radiocarbon 51, 337360.

Bryson, R., Wendland, W., Ives, J., Andrews, J., 1969. Radiocarbon Isochrones on the Disintegration of the Laurentide Ice Sheet. Arctic and Alpine Research 1, 1-13.

Chakraborty, K., Finkelstein, S., Desloges, J., Chow, N., 2010. Holocene paleoenvironmental changes inferred from diatom diatom assemblages in sediments of Kusawa Lake, Yukon Territory, Canada. Quaternary Research 74, 15-22.

Christoforou, P., Hameed, S., 1997. Solar cycle and the Pacific 'centers of action'. Geophysical Research Letters 24, 293-296.

Clegg, BF, Clarke, G., Chipman, M., Chou, M., Walker, I., Tinner, W, Hu, F., 2010. Six millennia of summer temperature variation based on midge analysis of lake sediments from Alaska. Quaternary Science Reviews 29, 3308-3316.

Cooper, M., O'Sullivan, P., Shine, A., 2000. Climate and solar variability recorded in Holocene laminated sediments - a preliminary assessment. Quaternary International 71, 363-371.

Coulter, B., 2003. LS 13320 Laser diffraction particle size analyzer instrument manual. Miami, Florida. 
Crann, C, Patterson, RT, Macumber AL, Galloway, JM, Roe, HM, Blauuw, M, Falck, H. 2013. Spatial and temporal variability in lake accumulation rates in Subarctic Northwest Territories, Canada (Working Title)

Cremer, H., Wagner, B., Melles, M., Hubberten, H.-W., 2001. The postglacial environmental development of Raffles Sø, East Greenland: inferences from a 10 , 000 year diatom record. Journal of Paleolimnology 26, 67-87.

D’Arrigo, R, Jacoby, G., Buckley, B., Sakulich, J., Frank, D., Wilson, R., Curtis, A., Anchukaitis, K., 2009. Tree growth and inferred temperature variability at the North American Arctic treeline. Global and Planetary Change 65, 71-82.

Dalton, A., Macumber, A., Vermaire, J., Patterson, R., Crann, C, Galloway, J., Falck, H, 2013. A 3330-year Multi-Proxy Climate Record from Canadian Sub-Arctic: Detection of Storm event at $1100 \mathrm{cal}$ yrBP and Potential for Time-series Analysis (Working Title).

Damon, PE, Jirikowic JL. 1992. The sun as a low-frequency harmonic oscillator. Radiocarbon 34, 199-205.

Davis, W., Gariepy, C., Breemen, O., 1996. Pb isotopic composition of late Archaean granites and the extent of recycling early Archaean crust in the Slave Province, northwest Canada. Chemical Geology 130, 255-269.

Dean, W., 1997. Rates , timing, and cyclicity of Holocene eolian activity in north-central United States : Evidence from varved lake sediments. Geology 25, 331-334.

Dean, W., Schwalb, A., 2000. Holocene environmental and climatic change in the Northern Great Plains as recorded in the geochemistry of sediments in Pickerel Lake, South Dakota. Quaternary International 67, 5-20.

Dearing, J., 1999. Environmental Magnetic Susceptibility using the Barington MS2 System. Witney, Oxford, England.

Douglas, M., Smol, J., Blake, W., 1994. Marked post-18th century environmental change in high-arctic ecosystems. Science $266,416-419$.

Dyke, A., Prest, V., 1987. Late Wisconsinan and Holocene History of the Laurentide Ice Sheet. Géographie physique et Quaternaire 41, 237.

Environment Canada, 2013. Canadian Climate Normals 1971-2000 Yellowknife. URL http://climate.weatheroffice.gc.ca/climate_normals/results_e.html?stnID $=1706 \&$ lang $=\mathrm{e} \& \mathrm{dCode}=1 \&$ province $=$ NWT \&provBut $=$ Search \&month $\overline{1}=0 \&$ month $2=12$ (accessed 5.30.13). 
Fallu, M.-A., Pienitz, R, Walker, I., Lavoie, M., 2005. Paleolimnology of a shrub-tundra lake and response of aquatic and terrestrial indicators to climatic change in arctic Québec, Canada. Palaeogeography, Palaeoclimatology, Palaeoecology 215, 183203.

Finkelstein, S., Gajewski, K, 2007. A palaeolimnological record of diatom-community dynamics and late-Holocene climatic changes from Prescott Island, Nunavut, central Canadian Arctic. The Holocene 17, 803-812.

Finkelstein, S., Gajewski, K, 2008. Responses of Fragilarioid-dominated diatom diatom assemblages in a small Arctic lake to Holocene climatic changes, Russell Island, Nunavut, Canada. Journal of Paleolimnology 1079-1095.

Fishbein E, Patterson RT, 1993. Error weighted maximum likelihood (EWML): a new statistically valid method to cluster quantitative micropaleontological data. Journal of Paleontology 67:475-486.

Galloway, J., Macumber, A., Patterson, R., Falck, H, Hadlari, T., Madsen, E., 2010. Paleoclimatological assessment of the southern Northwest Territories and implications for the long-term viability of the Tibbitt to Contwoyto Winter Road, Part I: Core collection.

Galloway, J., Wigson, A., Patterson, R., Swindles, G., Reindardt, E., Roe, H., 2013. Climate change and decadal to centennial-scale climate periodicities recorded in a Late Holocene NE Pacific marine record: Examining the role of solar forcing. Palaeogeography, Palaeoclimatology, Palaeoecology.

Gauthier, J., 1999. Unified structure in Quaternary climate. Geophysical Research Letters $26,763-766$.

Gray, L. J., Beer, J., Geller, M., Haigh, J. D., Lockwood, M., Matthes, K., Cubasch, U., Fleitmann, D., Harrison, G., Hood, L., Luterbacher, J., Meehl, G. A., Shindell, D., van Geel, 5 B., and White, W.: Solar influences on climate, Rev. Geophys., 48, RG4001, doi:10.1029/2009RG000282, 2010.

Geyh, M.A., Schotterer, U., Grosjean, M., 1998. Temporal changes of the 14C reservoir effect in lakes. Radiocarbon 40, 921-931.

Gleissberg, W., 1958. The 80-year sunspot cycle. Journal of the British Astronomical Association 68, 150.

Grimm, E.C., Maher Jr., L.J., Nelson, D.M., 2009.The magnitude of error in conventional bulk-sediment radiocarbon dates from central North America. Quaternary Research $72,301-308$. 
Grinsted, A., Moore, J., Jevrejeva, S., 2004. Nonlinear Processes in Geophysics Application of the cross wavelet transform and wavelet coherence to geophysical time series. Nonlinear Processes in Geophysics 11, 561-566.

Hameed, S., Lee, J.N., 2005. A mechanism for sun-climate connection. Geophysical Research Letters 32, L23817. http://dx.doi.org/10.1029/2005GL024393

Hammer, O., Harper, D., Ryan, P., 2001. PAST: Paleontological Statistics Software Package for Education and Data Analysis. Palaeontologia Electronica 4, 9.

Heiri, O., Lotter, A., Lemcke, G., 2001. Loss on ignition as a method for estimating organic and carbonate content in sediments; reproducibility and comparability of results. Journal of Paleolimnology 25, 101-110.

Hu, F., Kaufman, D, Yoneji, S., Nelson, D., Shemesh, A., Huang, Y., Tian, J., Bond, G., Clegg, B, Brown, T., 2003. Cyclic Variation and Solar Forcing of Holocene Climate in the Alaskan Subarctic. Science 301, 1890-1893.

Huang, C., MacDonald, G, Cwynar, L., 2004. Holocene landscape development and climatic change in the low arctic, Northwest Territories, Canada. Palaeogeography, Palaeoclimatology, Palaeoecology 205, 221-234.

Jackson, M., Oskarsson, N., Trønnes, R., McManus, J., Oppo, D., Grönvold, K., Hart, S., Sachs, J., 2005. Holocene loess deposition in Iceland: Evidence for millennial-scale atmosphere-ocean coupling in the North Atlantic. Geology 33, 509-512.

Jirikowic, JL and Damon PE. 1994. The Medieval Solar Activity Maximum. Climatic Change 26: 309-316.

Jones, P., Osborn, T., Briffa, K., 2001. The Evolution of Climate Over the Last Millennium. Science 292, 662-667.

Juggins, S., 2011. rioja: Analysis of Quaternary Science Data. Available: http://cran.rproject.org/web/packages/rioja/index.html.

Jungclaus, J. H., Lorenz, S. J., Timmreck, C., Reick, C. H., Brovkin, V., Six, K., Segschneider, J., Giorgetta, M. A., Crowley, T. J., Pongratz, J., Krivova, N. A., Vieira, L. E., Solanki, S. K., Klocke, D., Botzet, M., Esch, M., Gayler, V., Haak, H., Raddatz, T. J., Roeckner, E., Schnur, R., Widmann, H., Claussen, M., Stevens, B., and Marotzke, J. 2010. Climate and carbon-cycle variability over the last millennium, Clim. Past Discuss., 6, 1009-1044, doi:10.5194/cpd-6-1009-2010.

Karst-Riddoch, T., Pisaric, M., Smol, J., 2005. Diatom responses to 20th century climaterelated environmental changes in high-elevation mountain lakes of the northern Canadian Cordillera. Journal of Paleolimnology 33, 265-282. 
Kelly, P., Wigley, T., 1992. Solar cycle length, greenhouse forcing and global climate. Nature 360, 328-330.

Kern, A., Harzhauser, M., Piller, W., Mandic, O., Soliman, A., 2012. Strong evidence for the influence of solar cycles on a Late Miocene lake system revealed by biotic and abiotic proxies. Palaeogeography, palaeoclimatology, palaeoecology 329-330, 124 136.

Kohler, J., Hoeg, S., 2000. Phytoplankton selection in a river-lake system during two decades of changing nutrient supply. Hydrobiologia 424, 13-24.

Korhola, A., Virkanen, J., Tikkanen, M., and Blom, T. 1996. Fire- induced pH rise in a naturally acid hill-top lake, southern Finland: a paleoecological survey. J. Ecol. 84: $257-265$.

Krammer, K., Lange-Bertalot, H., 1991. Bacillariophyceae: vol 2 (1-4) Subwasserflora von Mitteleuropa.

Le Blanc, M., Gajewski, K., Hamilton, P.B., 2004. A diatom-based Holocene palaeoenvironmental record from a mid-arctic lake on Boothia Peninsula, Nunavut, Canada. The Holocene 14, 417-425.

Lean, J., Beer, J., Bradley, R., 1995. Reconstruction of solar irradiance since 1610 : Implications for climate change. Geophysical Research Letters 22, 3195-3198.

Lim, D.S.S., Smol, John P., Douglas, M.S. V., 2007. Recent environmental changes on Banks Island (N.W.T., Canadian Arctic) quantified using fossil diatom diatom assemblages. Journal of Paleolimnology 40, 385-398.

Lloyd, A.H., Fastie, C.L., College, M., 2003. Recent changes in treeline forest distribution and structure in interior Alaska 1. Proofs 10, 176-185.

Lotter, A.F., Bigler, C., 2000. Do diatoms in the Swiss Alps reflect the length of icecover? Aquatic Sciences 62, 125.

Luan, Y, Braconnot, P, Yu, Y, Zheng, W, Marti, O. 2012. Early and mid-Holocene climate in the tropical Pacific: seasonal cycle and interannual variability induced by insolation changes. Clim. Past 8, 1093-1108.

Macdonald, G., Edwards, T., Moser, K., Pienitz, R, Smol, J., 1993. Rapid response of treeline vegetation and lakes to past climate warming. Nature 361, 243-246.

Macdonald, G., Szeicz, J., Claricoates, J., Dale, K., Szeicz, M., Dale, A., 1998. Response of the Central Canadian Treeline to Recent Climatic Changes. Annals of the Association of American Geographers 88, 183-208. 
MacDonald, G.M., Porinchu, D.F., Rolland, N., Kremenetsky, K. V., Kaufman, D.S., 2009. Paleolimnological evidence of the response of the central Canadian treeline zone to radiative forcing and hemispheric patterns of temperature change over the past 2000 years. Journal of Paleolimnology 41, 129-141.

Macumber, A.L., Neville, L.A., Galloway, J.M., Patterson, R.T., Falck, Hendrik, Swindles, G.T., Crann, Carley, Clark, I., Gammon, P., Madsen, E., 2012. Climatological assessment of the Northwest Territories and implications for the long-term viability of the Tibbitt to Contwoyto Winter Road, Part II: March 2010 Field Season. Open Report for the NWT Geoscience Office, Yellowknife.

Macumber, A.L., Patterson, R.T., Neville, L.A., Falck, Hendrik, 2011. A sledge microtome for high resolution subsampling of freeze cores. Journal of Paleolimnology 45, 307-310.

Michelutti, Neal, Douglas, M.S.V., Smol, John P., 2003. Diatom response to recent climatic change in a high arctic lake (Char Lake, Cornwallis Island, Nunavut). Global and Planetary Change 38, 257-271.

Miller, G., Brigham-Grette, J., Alley, R., Anderson, L., Bauch, H., Douglas, M., Edwards, M., Elias, S., Finney, B., Fitzpatrick, J., Funder, S., Herbert, T., Hinzman, L., Kaufman, DS, MacDonald, GM, Polyak, L., Robock, A., Serreze, M., Smol, J., Spielhagen, R., White, J., Wolfe, A., Wolff, E., 2010. Temperature and precipitation history of the Arctic. Quaternary Science Reviews 29, 1679-1715.

Moser, K., Macdonald, G., 1990. Holocene vegetation change at treeline north of Yellowknife, northwest Territories, Canada. Quaternary Research 34, 227-239.

Murray, M., 2002. Is laser particle size determination possible for carbonate-rich lake sediments? Journal of Paleolimnology 27, 173-183.

Ogurtsov, MG, Nagovitsyn, YA, Kocharov, GE; Jungner, H. 2002. Long-period cycles of the sun's activity recorded in direct solar data and proxies. Solar Physics 211, 371394.

Papineau, JM. 2001. Wintertime temperature anomalies in Alaska correlated with ENSO and PDO. International Journal of Climatology 21, 1577-1592.

Patterson, RT., Chang, AS, Prokoph, A., Roe, H., Swindles, G., 2013. Influence of the Pacific Decadal Oscillation, El Niño-Southern Oscillation and solar forcing on climate and primary productivity changes in the northeast Pacific. Quaternary International.

Patterson, R.T., Fishbein, E., 1989. Re-examination of the statistical methods used to determine the number of point counts needed for micropaleontological quantitative research. Journal of Paleontology 63, 245-248 
Patterson, RT, Prokoph, A., Chang, A, 2004. Late Holocene sedimentary response to solar and cosmic ray activity influenced climate variability in the NE Pacific. Sedimentary Geology 172, 67-84.

Paul, C. a., Rühland, K.M., Smol, J.P., 2010. Diatom-inferred climatic and environmental changes over the last $29000 y e a r s$ from a low Arctic (Nunavut, Canada) tundra lake. Palaeogeography, Palaeoclimatology, Palaeoecology 291, 205-216.

Peristykh, A., Damon, P., 2003. Persistence of the Gleissberg 88-year solar cycle over the last 12,000years: Evidence from cosmogenic isotopes. Journal of Geophysical Research 108.

Perner, K., Moros, M., Jennings, a., Lloyd, J., Knudsen, K., 2012. Holocene palaeoceanographic evolution off West Greenland. The Holocene 23, 374-387.

Peros, M., Gajewski, Konrad, Paull, T., Ravindra, R., Podritske, B., 2010. Multi-proxy record of postglacial environmental change, south-central Melville Island, Northwest Territories, Canada. Quaternary Research 73, 247-258.

Pienitz, R, Smol, J., Macdonald, G., 1999. Paleolimnological Reconstruction of Holocene Climatic Trends from Two Boreal Treeline Lakes, Northwest Territories, Canada. Arctic, Antarctic, and Alpine Research 31, 82-93.

Porter, TJ, Pisaric, MFJ, Field, RD, Kokelj, SV, Edwards, TWD, deMontigny, P, Healy, R, LeGrande, AN. 2013. Spring-summer temperatures since AD 1780 reconstructed from stable oxygen isotope ratios in white spruce tree-rings from the Mackenzie Delta, northwestern Canada. Climate Dynamics. In press. DOI: 10.1007/s00382013-1674-3

R Development Core Team, 2012. R: A language and environment for statistical computing. Vienna, Austria. ISBN 3-900051-07-0, URL http://www.R-project.org.

Ram, M., Stolz, M., 1999. Possible solar influences on the dust profile of the GISP2 ice core from Central Greenland. Geophysical Research Letters 26, 1043-1046.

Reimer, P.J, Baillie, M., Bard, E., Bayliss, A., Beck, J., Blackwell, P., Bronk Ramsey, C., Buck, C., Burr, G., Edwards, R., Freidrich, M., Grootes, P., Guilderson, T., Hajdas, I., Heaton, T., Hogg, A., Hughen, K., Kaiser, K., Kromer, B., McCormac, F., Manning, S., Reimer, R., Richards, D., Southon, J., Talamo, S., Turney, C., Van der Plicht, J., Weyhenmeyer, C., 2009. IntCa109 and Marine09 Radiocarbon Age Calibration Curves, 0-50,000 Years cal BP. Radiocarbon 51, 1111-1150.

Reyes, A., Wiles, G., Smith, D., Barclay, D., Allen, S., Jackson, S., Larocque, S., Laxton, S., Lewis, D., Calkin, P., Clague, J., 2006. Expansion of alpine glaciers in Pacific North America in the first millennium A.D. Geology 34, 57-60. 
Reynolds, C.S., 1993. The Ecology of Freshwater Phytoplankton. Cambridge University Press, Cambridge. 384 pp.

Rolland, N., Larocque, I., Francus, P., Pienitz, Reinhard, Laperrière, L., 2008. Holocene climate inferred from biological ( Diptera: Chironomidae) analyses in a Southampton Island ( Nunavut, Canada ) lake. The Holocene 2, 229-241.

Rolland, N., Larocque, I., Francus, P., Pienitz, Reinhard, Laperrière, L., 2009. Evidence for a warmer period during the 12th and 13th centuries AD from chironomid diatom assemblages in Southampton Island, Nunavut, Canada. Quaternary Research 72, $27-$ 37.

Rühland, K., Smol, J., 2005. Diatom shifts as evidence for recent Subarctic warming in a remote tundra lake, NWT, Canada. Palaeogeography, Palaeoclimatology, Palaeoecology 226, 1-16.

Rühland, Kathleen M, Smol, John P, 2002. Freshwater diatoms from the Canadian arctic treeline and development of paleolimnological inference models.Journal of Phycology 264, 249-264.

Sandgren, P., Snowball, I., 2001. 8. Application of mineral magnetic techniques to paleolimnology, in: Last, W., Smol, J. (Eds.), Tracking Environmental Change Using Lake Sediments. Volume 2: Physical and Geochemical Methods. Kluwer Academic Publishers, Dordrecht, The Netherlands, pp. 217-237.

Saulnier-Talbot, E., Pienitz, R., Stafford Jr., T.W., 2009. Establishing Holocene sediment core chronologies for northern Ungava lakes, Canada, using humic acids (AMS $14 \mathrm{C}$ ) and 210Pb. Quaternary Geochronology 4, 278-287.

Seppa, H., Cwynar, L., Macdonald, G., 2003. Post-glacial vegetation reconstruction and a possible $8200 \mathrm{cal}$. yr BP event from the low arctic of continental Nunavut, Canada. Journal of Quaternary Science 18, 621-629.

Shannon CE, 1948. A Mathematical Theory of Communication. AT\&T Tech J, 27:379$423,623-656$.

Smol, J., 1985. The ratio of diatom frustules to chrysophycean statospores: A useful paleolimnological index. Hydrobiologia 123, 199-208.

Smol, J., 1988. Paleoclimate proxy data from freshwater arctic diatoms. Verh. Internat. Verein. Limnol. 23, 837-844.

Smol, J., Wolfe, A., Birks, H., Douglas, M., Jones, V., Korhola, A, Pienitz, R, Rühland, K., Sorvari, S, Antoniades, D., Brooks, S., Fallu, M.-A., Hughes, M., Keatley, B., Laing, T., Michelutti, N, Nazarova, L., Nyman, M., Paterson, A., Perren, B., 
Quinlan, R., Rautio, M., Saulnier-Talbot, E., Siitonen, S., Solovieva, N., Weckström, J., 2005. Climate-driven regime shifts in the biological communities of arctic lakes. Proceedings of the National Academy of Sciences of the United States of America 102, 4397-402.

Solanki, S., Usoskin, I., Kromer, B., Schussler, M., Beer, J., 2004. Unusual activity of the Sun during recent decades compared to the previous 11,000 years. Nature 431, 1084-1087.

Soon, W., Posamentier, E., Baliunas, S., 1996. Inference of solar irradiance variability from terrestrial temperature changes, 1880-1993: an astrophysical application of the Sun-climate connection. Journal of Astrophysics 472, 891-902.

Sorrel, P., Debret, M., Billeaud, I., Jaccard, S., McManus, J., Tessier, B., 2012. Persistent non-solar forcing of Holocene storm dynamics in coastal sedimentary archives. Nature Geoscience 5, 892-896.

Sorvari, S, Korhola, A, 1998. Recent diatom diatom assemblage changes in subarctic Lake Saanajarvi , NW Finnish Lapland, and their paleoenvironmental implications. Journal of Paleolimnology 205-215.

Steinhilber, F., Beer, J., Fröhlich, C., 2009. Total solar irradiance during the Holocene. Geophysical Research Letters 36. DOI: 10.1029/2009GL040142

Stubley, M., 1990. Preliminiary geology of the McCrea-Drybones Lakes area part of NTS 85 P/9,10. EGS Series 1990-4 Canada-NWT Mineral Development Agreement 1 map with Marginal notes.

Stuiver, M., 1975. Climate versus changes in 13C content of the organic components of lake sediments during the late Quaternary. Quaternary Research 5, 251-262.

Stuiver, M., Reimer, P.J., 1993. Extended 14C data base and revised CALIB 3.0 14C age calibration program. Radiocarbon 35, 215-230.

Sulfur, K. 2013. Personal communication. Re: pollen analysis on Danny's Lake sediment core.

Tammy, L., Michael, F.J., Donald, K., John, P., 2005. Postglacial record of diatom diatom assemblage changes related to climate in an alpine lake in the northern Rocky Mountains, Canada. Canadian Journal of Botany 83, 968-982.

Tinner, W, Bigler, C., Gedye, S., Gregory-Eaves, I., Jones, R.T., Kaltenrieder, P., Krähenbühl, U., Hu, F.S., 2008. A 700-year paleoecological record of boreal ecosystem responses to climatic variation from Alaska. Ecology 89, 729-43. 
Torrence, C., Compo, G., 1998. A Practical Guide to Wavelet Analysis. Bulletin of the American Meteorological Society 79, 61-78.

UCL, Department of Geography, 2013. Diatom Preparation. Webpage accessed March 2012. Available: http://www.geog.ucl.ac.uk/about-the-department/supportservices/laboratory/laboratory-methods/lake-sediment-analysis/diatom-preparation

Upiter, L., Vermaire, J., Patterson, R., Crann, C, Galloway, J., Macumber, A., Neville, L., Swindles, G., Falck, H, Roe, H., Pisaric, M., 2013. Mid- to late Holocene chironomid-inferred temperature variation for the central Northwest Territories, Canada. Journal of Paleolimnology In review.

Usoskin, I.G., Mursula, K., Solanki, S., Schüssler, M. and Alanko, K., 2004. Reconstruction of solar activity for the last millennium using 10Be data. Astron. Astrophys. 413, 745-751

Van Hengstum, P., Reinhardt, E., Boyce, J., Clark, C., 2007. Changing sedimentation patterns due to historical land-use change in Frenchman's Bay, Pickering, Canada: evidence from high-resolution textural analysis. Journal of Paleolimnology 37, 603618.

Viau, A., Gajewski, K, 2009. Reconstructing Millennial-Scale, Regional Paleoclimates of Boreal Canada during the Holocene. Journal of Climate 22, 316-330.

Veizer, J. 2005. Celestial Climate Driver: A Perspective From Four Billion Years Of The Carbon Cycle. Geoscience Canada 32, 13-30

Wagner, G., Beer, J., Muscheler, M., Kubik, P., Laj, C., Raisbeck, G., Yiou, F., 2001. Presence of the solar de Vries cycle ( 205 years) during the last ice age. Geophysical Research Letters 28, 303-306.

Wiles, G., D’Arrigo, RD, Villalba, R., Calkin, P., Barclay, D., 2004. Century-scale solar variability and Alaskan temperature change over the past millennium. Geophysical Research Letters 31, L15203.

Wolfe, B., Edwards, T., Aravena, R., Macdonald, G., 1996. Rapid Holocene hydrologic change along boreal tree- line revealed by delta $13 \mathrm{C}$ and delta $18 \mathrm{O}$ in organic lake sediments, Northwest Territories, Canada. Journal of Paleolimnology 15, 171-181.

Wu, J., Yu, Z., Zeng, H., Wang, N., 2009. Possible solar forcing of 400-year wet-dry climate cycles in northwestern China. Climatic Change 96, 473-482.

Zabenskie, S., Gajewski, K, 2007. Post-Glacial climatic change on Boothia Peninsula, Nunavut, Canada. Quaternary Research 68, 261-270. 
Appendix A. Co-author involvement declaration forms 


\section{Statement of Co-authors on Collaborative Activity Carleton}

Re: M.Sc disserlation prepared by April Suc Dalton for defence in July 2013

Chapter 2 - A 3330-year Multi-Proxy Climate Record from Canadian Subarctic: Detection of Storm event at 1100 cal yrRP and Potential for Tïme Series Analysis *

The purpose of this document is to assure examiners and those reading this dissertatikn that there has becn full disclosure of collaborative activity. April Sue Dalton was fully inwolved in setting up and conducting the rescarch, obtaining dala and analyzing results, as well as preparing and writing the material presented in the co-authored articles integrated in this thesis. The nalure of my contribution to the co-suthurred article is as follows:

- Contribution of particle size analysis dala as a secondary proxy

- Scdiment core acquisition and subsampling via sledge microtame

- Intellectual contriburions, as well as aid in reviewing manuscript prior to inclusion in this thesis

I give permission lor my work to be included in this M.Se lissertation. Mỵ contributions as a coauthor were adequately doclared abowe and I have taken into consideration the rules and regulations of Carlcton Universily's Academic Integrity policy**.

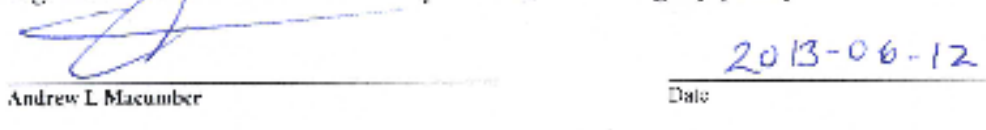

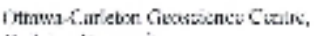

Carlam lat:aersin:

Ollaws, Julath

* Working tille-subject to change. Regardess of title, this declaration of co-authorship pertains to Cheppler 2 of the M.Sc thesis by April Sive Datlon,

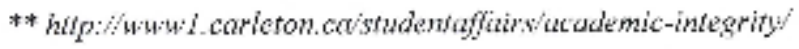




\section{Statement of Co-authors on Collaborative Activity}

\section{Carleton UNIVERSITY}

Re: M.Sc dissertation prepared by April Sue Dalton for defence in July 2013

Chapter 2 - A 3330-year Multi-Proxy Climate Record from Canadian Subarctic: Detection of Storm event at 1100 cal yrBP and Potential for Time Series Analysis *

The purpose of this document is to assure examiners and those reading this dissertation that there has been full disclosure of collaborative activity. April Sue Dalton was fully involved in setting up and conducting the research, obtaining data and analyzing results, as well as preparing and writing the material presented in the co-authored articles integrated in this thesis. The nature of my contribution to the co-authored article is as follows:

- Teaching sediment preparation techniques for diatom analysis

- Aid in diatom identification and enumeration

- Intellectual contribution to diatom ecology and interpretation, as well as aid in reviewing manuscript prior to inclusion in this thesis

I give permission for my work to be included in this M.Sc dissertation. My contributions as a coauthor were adequately declared above and I have taken into consideration the rules and regulations of Carleton University's Academic Integrity policy**.

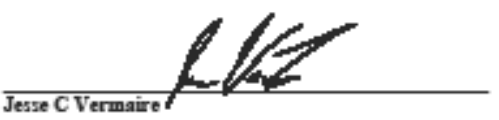

Carleton University Paleoecological Laboratory, Oetawn, Ontario
June 112013

\footnotetext{
* Working title - subject to change. Regardless of title, this declaration of co-authorship pertains to Chapter 2 of the M.Sc thesis by April Sue Dalton.

** http://wwwl.carleton.ca/studentaffairs/academic-integrity/
} 


\section{Statement of Co-authors on Collaborative Activity}

\section{Carleton W UNIVERSITY}

Re: M.Sc dissertation prepared by April Sue Dalton for defence in July 2013

\section{Chapter 2 - A 3330-ycar Multi-Pruxy Climate Record from Canadian Subarctic: Detection of Storm event at 1100 cal yrbP and Poteutial for Time Series Analysis *}

The purpose of this discument is to assure examiners and those reading this disscrtation that there has heen full disclosure of collaborative activity. April Sue Dulın was fully irnvilved in setting up and conducting the research, obtaining datu and analyzing results, as well as preparing and writing the matcrial presented in the co-authored articles integrated in this thesis. The nature of my comlribution to the co-authored article is as follows:

- Supervisor to student and Principal Investigator of the 2009 NSERC Strategic Grant "Impact of "elimate change on the long-term viability of the strategically importanl Tihhilt. wo Contwoy to winter road. Northwest Territories, Caneda"

- Sediment corc collection, amalysis and logistics

- Aid in interpretation of results, as well as aid in reviewing manuscript prior to inclusion in this thesis

T give permission for my work to be included in this M.Se disertation. My contributions as a coauthor were adcquatcly declared above and $T$ have taken into consideration the rulcs and regulations of Carletum Ciniversity's Academic Integrity policy**.

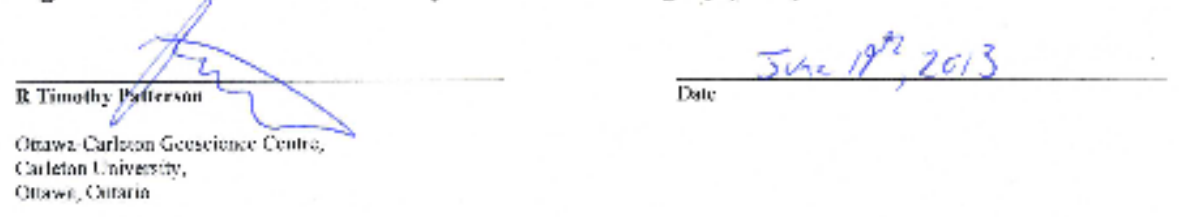
Ollawe, Chirariá

\footnotetext{
* Working isile - subject to change. Regardless of wite, this dectaration of co-atthorship pertains to Chapter 2 of the M.Sc thesis by April Sue Dation.

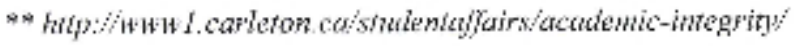




\section{Statement of Co-authors on Collaborative Activity}

\section{Carleton UNIVERSITY}

Re: M.Sc dissertation prepared by April Sue Dalton for defence in July 2013

Chapter 2 - A 3330-year Multi-Proxy Climate Record from Canadian Subarctic: Detection of Storm event at 1100 cal yrBP and Potential for Time Series Analysis *

The purpose of this document is to assure examiners and those reading this dissertation that there has been full disclosure of collaborative activity. April Sue Dalton was fully involved in setting up and conducting the research, obtaining data and analyzing results, as well as preparing and writing the material presented in the co-authored articles integrated in this thesis. The nature of my contribution to the co-authored article is as follows:

- Co-Investigator of the 2009 NSERC Strategic Grant "Impact of climate change on the long-term viability of the strategically important Tibbitt to Contwoyto winter road, Northwest Territories, Canada"

- Sediment core collection, analysis and logistics, as well as aid in data interpretation

I give permission for my work to be included in this M.Sc dissertation. My contributions as a coauthor were adequately declared above and I have taken into consideration the rules and regulations of Carleton University's Academic Integrity policy**.

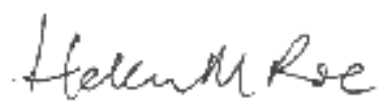

13 June 2013

Helen M Roe

Date

School of Geography, Archasology and Palaeoecology.

Queen's Univerwity of Belfast,

Belfast, UI

* Working title - subject to change. Regardless of title, this declaration of co-authorship pertains to Chapter 2 of the M.Sc thesis by April Sue Dalton.

** http://wwwl.carleton.ca/studentaffairs/academic-integrity/ 


\section{Statement of Co-authors on Collaborative Activity}

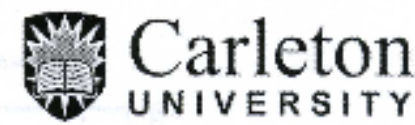

Re: M.Sc dissertation prepared by April Suc Dalton for defence in July 2013

\section{Chapter 2 - A 3330-year Multi-Proxy Climate Record from Canadian Subarctica Detcetion} of Storm event at 1100 cal yr BP and Potential for Time Series Analysis *

The purpose of this document is to assure examiners and those rewding this dissertalion that. there has becn full disclosure of collaborative activity. $A$ pril Sue Dalton was fully involved in setting up and conducting the rescarch, obtaining data and analyzing results, as well as preparing and writing the material presented in the cr-authored articles integraled in this thesis. The naturc of my contribution to the co-authored article is as follows:

- Construclion all high resolution age-depth model for Danny's Lake sediment corc

- Aid in incerpretation of results, as well as aid in reviewing manuscript prisır to inclusion in this thesis

I give permission for my work to be included in this M.Sc disscrtation. My contributions as a couuthor were adequately declared above and I have taken into consideration the rules and regylpatiums of Carleton Iniversity's Atudemic Inlegrity policy 88 .
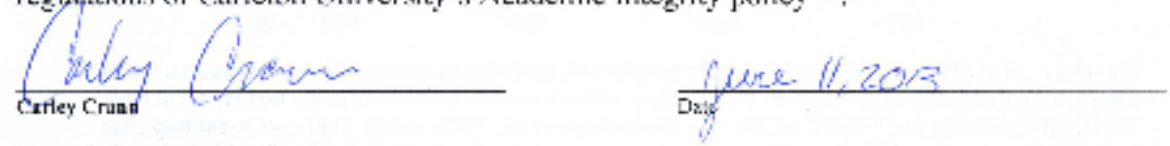

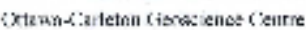

Gitelen Unircrsily,

Otzus, On:arie

* Working ittle swbject to change. Regordless of sile, thiv declaration of co-aulhorship periainx to Chapter 2 of the MS.St lhesis by April Sue Daton.

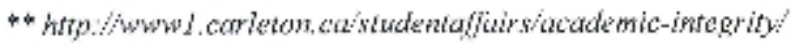




\section{Statement of C0-authors on Collaborative Activity}

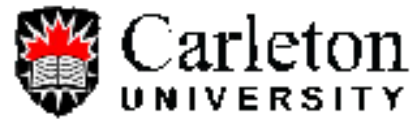

Re: M.Sc dissertation prepared by April Sue Dalton for defence in July 2013

Chapter 2 - A 3330-year Multi-Proxy Climate Record from Canadian Subarctic: Detection of Storm event at 1100 cal yrBP and Potential for Time Series Analysis *

The purpose of this document is to assure examiners and those reading this dissertation that there has been full disclosure of collaborative activity. April Sue Dalton was fully involved in setting up and conducting the research, obtaining data and analyzing results, as well as preparing and writing the material presented in the co-authored articles integrated in this thesis. The nature of my contribution to the co-authored article is as follows:

- Grant funding provided by NWT Cumulative Impact Monitoring Program for sediment core collection, field work logistics and subsequent data analysis

- Aid in interpretation of results, as well as aid in reviewing mamuscript prior to inclusion in this thesis

I give permission for my work to be included in this M.Sc dissertation. My contributions as a coauthor were adequately declared above and I have taken into consideration the rules and regulations of Carleton University's Academic Integrity policy**.

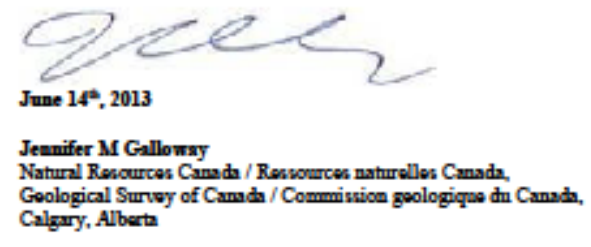

* Working title - subject to change. Regardless of title, this declaration of co-authorship pertains to Chapter 2 of the M.Sc thesis by April Sue Dalton.

** http://wwwl.carleton.ca/studentaffairs/academic-integrity/ 
Statement of Co-authors on Collaborative Activity

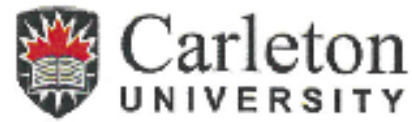

Rc: M.Sc disscrtation preparcd by April Sue Dalton for delence in July 2013

Chapter 3 - Diatom Data Reveal Solar Forcing as a Late Holocene Climate Control in Canadian Subarctic *

The purposc of this document is to assure examiners and those reading this disserlation that there has bocn full disclosure of collaborative activity. April Sue Dalton was lully involved in selling up and conducting the research, obtaining data and analyzing results, as well as preparing and writing the muterial presentel in the co-guthored articles integrated in this thesis. The nature of my contribution to the co-nuthored article is as lollows:

- Grant fuading providod by NWT Cumulative Impact Monitoring Program for swliment arre esollection, field wark loyisties and subsequent data analysis.

- Aid in interprelation ol results, as well as aid in reviewing manuscript prior to inclusion in this thesis

I give permisision lim my work $\mathrm{kt}$ he incluted in this M.Sc dissertation. My contributions as a corauthor wrere adequately declared above and I have taken into comsitcration the rules and regulations of Carlcton University's Academic Integrity policy**
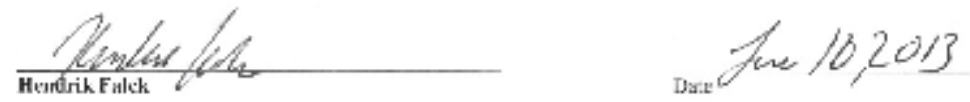

Vothwest Jerimries Sienecien:e Office. Yel moknite, Notivass latito ies

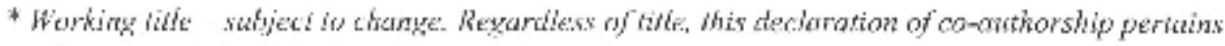
to Chapter 3 of the A.Sc thesis by April Sue Dalion.

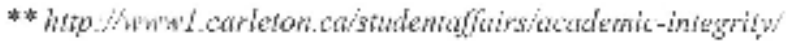




\section{Statement of Co-authors on Collaborative Activity}

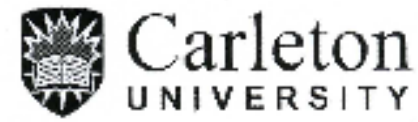

Re: M.Sc dissertution prepared by April Suc Dalton for defence in July 2013

\section{Chapter 3 - Diatom Data Reveal Solar Foreing as a I alc I Iolocene Climate Control in Cauadian Subarctic *}

The purposc of this document is to assure examiners and those reading this disscrtation that. there has been full disclosure of collaborative activity. April Sue Dalton wus fully involved in setting up and conducting the rescarch, obtaining data and andyzing results, as well as proparing and writing the matcrial presented in the co-authored articles integrated in this thesis. The nature of my contribution to the co-authored article is as follows:

- Sediment corc collection, subsampling and ir data interpretation

1 give permission for my work to be included in this M.Sc disscrtation, My cumbihulions as a coauthor were udequately declared above and I have taken into consideration the rules and regulations of Carleton University's Academic Integrity poliç̣" ".

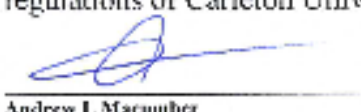

$20,3.06-12$

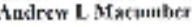

$\overline{\text { Datr }}$

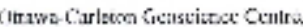

caitetan L niversity

Oex $\rightarrow$ n Cirarie

* Horking tivle - swhject a change. Regardless of vile, his deciaration of co-cuthorship pertaing to Chapter 3 of the Misc thesis by April Sue Dalion

** hign: wew l.carleton cafstudeniaffairsiacademic-integrity 


\section{Statement of Co-authors on Collaborative Activity}

\section{Carleton UNIVERSITY}

Re: M.Se dissertalion prepared by April Sue Dallun lior defence in July 2013

\section{Chapter 3 - Diatom Data Reveal Solar Forcing as a Late Holocene Climate Control in Canadian Subarctic *}

The purpose of this document is on assure examiners and those reading this lissertation that there has becn full disclosure of collaborative activity. April Sue Dalton was fully involved in sctting up and comducting the rescarch, obtaining dala and analyzing results, as well as preparing and writing the material presented in the co-authored articles integrated in this thesis. The nature of my contribution to the co-authored article is as follows:

- Supervisor to student and Principal Investigator of the 2009 NSERC Stratcgic Grant. "Impact of climate change on the long-term viability of the strategieally important Tibbitt to Contwoyto winter roal, Nisthwest T'erritorics, Canada"

- Scdiment core tollection, analysis and logislics

- Aid in interpretation of results, as well as add in revicwing manuscript prior k inclusion in this thesis

I give permission for my work to be included in this M.Se dissertation. My contributions as a toauthor were adequately declared above and I have taken into consideration the rules and regulations of Carleton Universily's Academic Integrity policy*8.
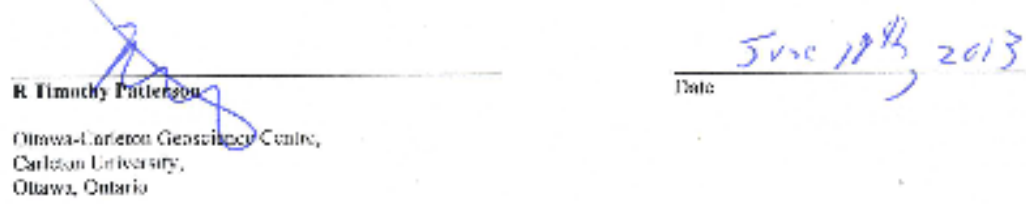

Carlitum Lrisusty.

* Worhing tinle - subject in change. Regardless of inle, this declaration of co-aushorship periains to Chupter 3 of ine M.ic thesis by April Sice Dallon.

** htp:/4ww'carleton.ca/studentaffirs/academic-integrity 


\section{Statement of Co-authors on Collaborative Activity}

\section{Carleton}

Re: M.Sc dissertation prepared by April Sue Dalton for defence in July 2013

Chapter 3 - Diatom Data Reveal Solar Forcing as a Late Holocene Climate Control in Canadian Subarctic *

The purpose of this document is to assure examiners and those reading this dissertation that there has been full disclosure of collaborative activity. April Sue Dalton was fully involved in setting up and conducting the research, obtaining data and analyzing results, as well as preparing and writing the material presented in the co-authored articles integrated in this thesis. The nature of my contribution to the co-authored article is as follows:

- Spectral, wavelet and cross-wavelet analysis of diatom and total solar irradiance data

- Aid in interpretation of results, as well as aid in reviewing manuscript prior to inclusion in this thesis

I give permission for my work to be included in this M.Sc dissertation. My contributions as a coauthor were adequately declared above and I have taken into consideration the rules and regulations of Carleton University's Academic Integrity policy**.

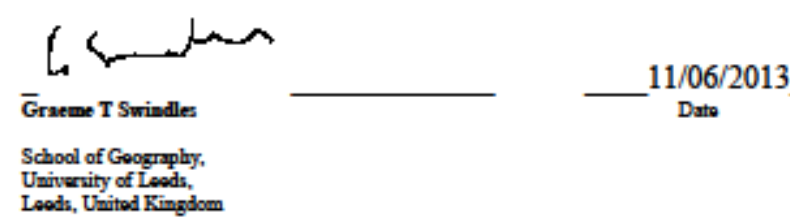

* Working title-subject to change. Regardless of title, this declaration of co-authorship pertains to Chapter 3 of the M.Sc thesis by April Sue Dalton.

** http://wwwl.carleton.ca/studentaffairs/academic-integrity/ 


\section{Statement of Co-authors on Collaborative Activity}

\section{Carleton UNIVERSITY}

Re: M.Sc dissertation prepared by April Sue Dalton for defence in July 2013

Chapter 3 - Diatom Data Reveal Solar Forcing as a Late Holocene Climate Control in Canadian Subarctic *

The purpose of this document is to assure examiners and those reading this dissertation that there has been full disclosure of collaborative activity. April Sue Dalton was fully involved in setting up and conducting the research, obtaining data and analyzing results, as well as preparing and writing the material presented in the co-authored articles integrated in this thesis. The nature of my contribution to the co-authored article is as follows:

- Co-Investigator of the 2009 NSERC Strategic Grant "Impact of climate change on the long-term viability of the strategically important Tibbitt to Contwoyto winter road, Northwest Territories, Canada"

- Sediment core collection, analysis and logistics, as well as aid in interpretation of results I give permission for my work to be included in this M.Sc dissertation. My contributions as a coauthor were adequately declared above and I have taken into consideration the rules and regulations of Carleton University's Academic Integrity policy**.

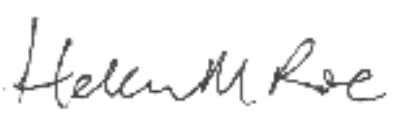

Helen M Roe

13 June 2013

Scbool of Goography, Archseology and Palaøoecology. Queen's Univerwity of Belfast, Bolfast, UK

Date

* Working title-subject to change. Regardless of title, this declaration of co-authorship pertains to Chapter 3 of the M.Sc thesis by April Sue Dalton.

** http://wwwl.carleton.ca/studentaffairs/academic-integrity/ 


\section{Statement of Co-authors on Collaborative Activity}

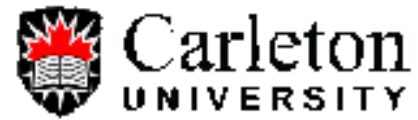

Re: M.Sc dissertation prepared by April Sue Dalton for defence in July 2013

\section{Chapter 3 - Diatom Data Reveal Solar Forcing as a Late Holocene Climate Control in} Canadian Subarctic *

The purpose of this document is to assure examiners and those reading this dissertation that there has been full disclosure of collaborative activity. April Sue Dalton was fully involved in setting up and conducting the research, obtaining data and analyzing results, as well as preparing and writing the material presented in the co-authored articles integrated in this thesis. The nature of my contribution to the co-authored article is as follows:

- Grant funding provided by NWT Cumulative Impact Monitoring Program for sediment core collection, field work logistics and subsequent data analysis

- Aid in interpretation of results, as well as aid in reviewing manuscript prior to inclusion in this thesis

I give permission for my work to be included in this M.Sc dissertation. My contributions as a coauthor were adequately declared above and I have taken into consideration the rules and regulations of Carleton University's Academic Integrity policy**.

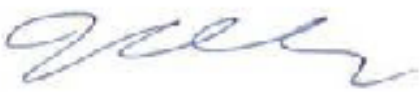

June $14^{4}, 2013$

Jeanifer M Gallowsy

Natural Rescurces Canada / Resvources naturelles Camada. Goological Survoy of Camad / Commission geologigas du Canadh, Calgary, Alberta

* Working title - subject to change. Regardless of title, this declaration of co-authorship pertains to Chapter 3 of the M.Sc thesis by April Sue Dalton.

** http://wwwl.carleton.ca/studentaffairs/academic-integrity/ 


\section{Statement of Co-authors on Collaborative Activity}

\section{Carleton UN IVERSIT Y}

Re: M.Sc dissertation prepared by April Sue Dalton for defence in July 2013

\section{Chapter 2 - $\Lambda$ 3330-year Multi-Proxy Climate Record from Canadian Subarctic: Detection of Storm event at 1100 cal yrBP and Potential four Time Series Analysis *}

The purpose of this document is to assure examiners and those reading this dissertation that there has becn full disclosure of collaborative activity. April Suc Dalton was fully involved in sclling up and cumlueting the reseand, ohtaining data and ansly/ng results, ak woll as preparing anul writing the material presented in the co-authured articles integruled in this thesis. The nature of my contribution to the co-authored article is as follows:

- Grant funding providod by NWT Cumulative lmpact Monitoring l'rogram for sediment core collection, field work log̣istics nnd subsequent datn analysis.

- Aid in interpretation of results, as well as aid in revicwing manuscript prior to inclusion in this thesis

I give permission for my work to be included in Lhis M.Se discerlation. My unntrihutions as a coauthor were adequately doclared above and I have taken into consideration the rules ant regulations of Carleton University's Academic Integrity policy'm.

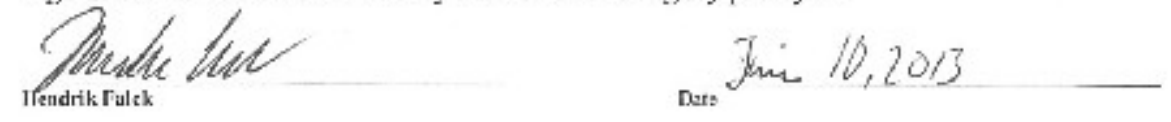

Varthest Ter laris Gorenente Office

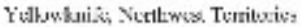

- Working tille - subject io change. Regardless of tilte, this dectaraion of co-authorship pertning to Chopter 2 of the M.Sc thesis by April Sue Daiton.

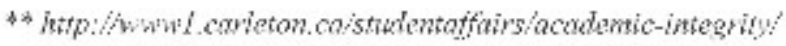




\section{Appendix B. Diatom species names and authorities according to Krammer \& Lange-Bertlot (1991)}

Diatom species names and authorities according to Krammer \& Lange-Bertlot (1991). Updated species names and NADED ID numbers (in parentheses) according to Academy of Natural Sciences and collaborators (2011-2013) 
Appendix B. Diatom species names and authorities according to Krammer \& Lange-Bertlot (1991)

\begin{tabular}{|c|c|c|}
\hline Species & Authority & Updated Species Name \\
\hline Achnanthes curtissima & Carter & Psammothidium curtissimum (186021) \\
\hline Achnanthes didyma & Hustedt & Psammothidium didymum (186012) \\
\hline Achnanthes flexella & (Kützing ) Brun & Eucocconeis flexella (187001) \\
\hline Achnanthes helvetica & (Hustedt)Lange-Bertalot & Psammothidium helveticum (186003) \\
\hline Achnanthes holsatica & Hustedt & Platessa holsatica (2508002) \\
\hline Achnanthes imperfecta & Schimanski & Achnanthes imperfecta (2051) \\
\hline Achnanthes joursacense & Heribaud & Planothidium joursacense (155016) \\
\hline Achnanthes laevis & Østrup & Eucocconeis laevis (187002) \\
\hline Achnanthes laterostrata & Hustedt & Karayevia laterostrata (125002) \\
\hline Achnanthes levanderi & Hustedt & Achnanthes levanderi (2022) \\
\hline Achnanthes minutissima & Kützing & Achnanthidium minutissimum (1010) \\
\hline Achnanthes nodosa & Cleve & Rossithidium nodosum (189006) \\
\hline Achnanthes Østrupii & (Cleve-Euler) Hustedt & Planothidium oestrupii (155026) \\
\hline Achnanthes pergalli & Brun\&Heribaud & - \\
\hline Achnanthes ploenensis & Hustedt & Karayevia ploenensis (125008) \\
\hline Achnanthes pseudoswazi & Carter & Achnanthes pseudoswazi (2206) \\
\hline Achnanthes pusilla & (Grunow) De Toni & Rossithidium pusillum (189003) \\
\hline Achnanthes semiaperta & Hustedt & Achnanthidium semiapertum (1028) \\
\hline Achnanthes suchlandtii & Hustedt & Karayevia suchlandtii (125009) \\
\hline Achnanthes trinodis & (W Smith) Grunow & Achnanthes trinodis (2109) \\
\hline Achnanthes ventralis & (Krasske) Lange-Bertalot & Psammothidium ventralis (186009) \\
\hline Amphipleura lindheimerii & Grunow & - \\
\hline Amphora libyca & Ehrenberg & Amphora copulata (7075) \\
\hline Amphora ovalis & (Kützing ) Kützing & Amphora ovalis (7001) \\
\hline Anomoeoneis brachysira & (Brebisson) Grunow & Brachysira brebissonii (18005) \\
\hline Anomoeoneis vitrea & (Grunow) Ross & Brachysira microcephala (18013) \\
\hline Aulacoseira alpigena & (Grunow) Krammer & Aulacoseira alpigena (10028) \\
\hline Aulacoseira ambigua & (Grunow) Simonsen & Aulacoseira ambigua (10008) \\
\hline Aulacoseira canadensis & (Hustedt) Simonsen & Aulacoseira canadensis (10003) \\
\hline Aulacoseira crassipunctata & Krammer & Aulacoseira crassipunctata (10001) \\
\hline Aulacoseira crenulata & (Ehrenberg) Thwaites & Aulacoseira italica (10019) \\
\hline Aulacoseira distans & (Ehrenberg) Simonsen & Aulacoseira distans (10009) \\
\hline Aulacoseira granulata & (Ehrenberg) Simonsen & Aulacoseira granulata (10018) \\
\hline Aulacoseira lacustris & (Grunow) Krammer & Aulacoseira lacustris (10060) \\
\hline Aulacoseira lirata & (Ehrenberg) Ross & Aulacoseira lirata (10012) \\
\hline Aulacoseira muzzanensis & (Meister) Krammer & Aulacoseira muzzanensis (10031) \\
\hline Aulacoseira perglabra & (Østrup) Haworth & Aulacoseira perglabra (10006) \\
\hline
\end{tabular}


Appendix B. Diatom species names and authorities according to Krammer \& Lange-Bertlot (1991)

\begin{tabular}{|c|c|c|}
\hline Species & Authority & Updated Species Name \\
\hline Aulacoseira subarctica & (O Müller) Haworth & Aulacoseira subarctica (10015) \\
\hline Aulacoseira tethera & Haworth & Aulacoseira tethera (10033) \\
\hline Aulacoseira valida & (Grunow) Krammer & Aulacoseira valida (10029) \\
\hline Bacillaria paradoxa & O Müller & Bacillaria paradoxa (76001) \\
\hline Caloneis alpestris & Cleve & Caloneis alpestris (12025) \\
\hline Caloneis lauta & Carter\&Bailey-Watts & Caloneis lauta (12026) \\
\hline Caloneis permagna & (Bailey) Cleve & Caloneis permagna (12030) \\
\hline Caloneis silicula & (Ehrenberg) Cleve & Caloneis silicula (12010) \\
\hline Caloneis tenuis & (Gregory) Krammer & Caloneis tenuis (12013) \\
\hline Caloneis thermalis & (Grunow) Krammer & Caloneis thermalis (12054) \\
\hline Caloneis undulata & (Gregory) Krammer & Caloneis undulata (12022) \\
\hline Caloneis westii & (W Smith) Hendey & Caloneis westii (12056) \\
\hline Cocconeis placentula & Ehrenberg & Cocconeis placentula (16004) \\
\hline Cyclotella bodanica & Grunow & Puncticulata bodanica (208004) \\
\hline Cyclotella comensis & Grunow & Cyclotella comensis (20023) \\
\hline Cyclotella krammeri & Hakansson & Cyclotella krammeri (20083) \\
\hline Cyclotella ocellata & Pantocsek & Cyclotella ocellata (20009) \\
\hline $\begin{array}{l}\text { Cyclotella } \\
\text { pseudostelligera }\end{array}$ & Hustedt & $\begin{array}{l}\text { Discostella pseudostelligera } \\
(2506002)\end{array}$ \\
\hline Cyclotella rossii & Hakansson & Cyclotella rossii (20019) \\
\hline Cyclotella stelligera & Cleve \& Grunow & Discostella stelligera (2506003) \\
\hline Cyclotella tripartita & Hakansson & Cyclotella tripartita (20085) \\
\hline Cymbella affinis & Kützing & Cymbella affinis (23073) \\
\hline $\begin{array}{l}\text { Cymbella } \\
\text { amphicephala }\end{array}$ & Nägeli & Cymbella amphicephala (23001) \\
\hline Cymbella angustata & (W Smith) Cleve & Cymbopleura angustata (190013) \\
\hline Cymbella cesatii & (Rabenhorst) Grunow & Cymbella cesatii (23004) \\
\hline Cymbella cistula & (Ehrenberg) Kirchner & Cymbella cistula (23005) \\
\hline Cymbella cuspidata & Kützing & Cymbopleura cuspidata (190001) \\
\hline Cymbella descripta & $\begin{array}{l}\text { (Hustedt) Krammer \& Lange- } \\
\text { Bertalot }\end{array}$ & Encyonopsis descripta (203014) \\
\hline Cymbella elginensis & Krammer & Encyonema elginense (110044) \\
\hline Cymbella falaisensis & $\begin{array}{l}\text { (Grunow) Krammer \& Lange- } \\
\text { Bertalot }\end{array}$ & Encyonopsis falaisensis (203007) \\
\hline Cymbella gaeumannii & Meister & Encyonema gaeumannii (110008) \\
\hline Cymbella gracilis & (Ehrenberg) Kützing & Encyonema neogracile (110045) \\
\hline Cymbella helvetica & Kützing & Cymbella helvetica (23099) \\
\hline Cymbella heteropleura & (Ehrenberg) Kützing & Cymbella heteropleura (23100) \\
\hline Cymbella lapponica & Grunow & Cymbella lapponica (23116) \\
\hline Cymbella microcephala & Grunow & $\begin{array}{l}\text { Encyonopsis microcephala } \\
\text { (203002) }\end{array}$ \\
\hline Cymbella minuta & Hilse & Encyonopsis minuta (203011) \\
\hline Cymbella rupicola & Grunow & Cymbella rupicola (23020) \\
\hline Cymbella schimanskii & Krammer & - \\
\hline Cymbella sileiaca & Bleisch & - \\
\hline
\end{tabular}


Appendix B. Diatom species names and authorities according to Krammer \& Lange-Bertlot (1991)

\begin{tabular}{|c|c|c|}
\hline Species & Authority & Updated Species Name \\
\hline Cymbella sinuata & Gregory & Reimeria sinuata (55002) \\
\hline Cymbella subaequalis & Grunow & Cymbopleura subaequalis (190017) \\
\hline Cymbella tumidula & Grunow & Cymbella tumidula (23082) \\
\hline Cymbella tynnii & Krammer & Cymbella tynnii (47141) \\
\hline Denticula elegans & Kützing & Denticula elegans (25001) \\
\hline Denticula keutzingii & Grunow & - \\
\hline Diatoma mesodon & (Ehrenberg) Kützing & Diatoma mesodon (27002) \\
\hline Diatoma vulgaris & Bory & Diatoma vulgaris (27013) \\
\hline Diploneis boldtiana & Cleve & Diploneis boldtiana (30012) \\
\hline Diploneis elliptica & (Kützing ) Cleve & Diploneis elliptica (30001) \\
\hline Diploneis finnica & (Ehrenberg) Cleve & Diploneis finnica (30002) \\
\hline Diploneis marginestriata & Hustedt & Diploneis marginestriata (30003) \\
\hline Diploneis ovalis & (Hilse) Cleve & Diploneis ovalis (30009) \\
\hline Diploneis parma & Cleve & Diploneis parma (30014) \\
\hline Epithemia adnata & (Kützing ) Brebisson & Epithemia adnata (32003) \\
\hline Epithemia smithii & Carruthers & Epithemia smithii (32002) \\
\hline Epithemia sorex & Kützing & Epithemia sorex (32006) \\
\hline Eunotia arcus & Ehrenberg & Eunotia arcus (33001) \\
\hline Eunotia bigibba & Kützing & Eunotia bigibba (33005) \\
\hline Eunotia bilunaris & (Ehrenberg) Mills & Eunotia bilunaris (33185) \\
\hline Eunotia circumborealis & $\begin{array}{l}\text { Lange-Bertalot \& } \\
\text { Norpel }\end{array}$ & Eunotia circumborealis (33210) \\
\hline Eunotia denticulata & $\begin{array}{l}\text { (Brebisson) } \\
\text { Rabenhorst }\end{array}$ & Eunotia denticulata (33011) \\
\hline Eunotia exigua & $\begin{array}{l}\text { (Brebisson) } \\
\text { Rabenhorst }\end{array}$ & Eunotia exigua (33015) \\
\hline Eunotia faba & Ehrenberg & Eunotia faba (33172) \\
\hline Eunotia implicata & Norpel & Eunotia implicata (33168) \\
\hline Eunotia incisa & Gregory & Eunotia incisa (33026) \\
\hline Eunotia minor & (Kützing ) Grunow & Eunotia minor (33183) \\
\hline Eunotia monodon & Ehrenberg & Eunotia monodon (33035) \\
\hline Eunotia muscicola & Krasske & Eunotia muscicola (33184) \\
\hline Eunotia paludosa & Grunow & Eunotia paludosa (33083) \\
\hline Eunotia pectinalis & (Dillwyn) Rabenhorst & Eunotia pectinalis (33039) \\
\hline Eunotia praerupta & Ehrenberg & Eunotia praerupta (33045) \\
\hline Eunotia rhomboidea & Hustedt & Eunotia rhomboidea (33051) \\
\hline Eunotia rhynchocephala & Hustedt & Eunotia rhynchocephala (33191) \\
\hline Eunotia septentrionalis & Østrup & Eunotia septentrionalis (33053) \\
\hline Eunotia serra & Ehrenberg & Eunotia serra (33054) \\
\hline Eunotia soleirolii & (Kützing ) Rabenhorst & Eunotia soleirolii (33056) \\
\hline Fragilaria brevistriata & Grunow & $\begin{array}{l}\text { Pseudostaurosira brevistriata } \\
\text { (73001) }\end{array}$ \\
\hline Fragilaria capucina & Desmazieres & Fragilaria capucina (34006) \\
\hline Fragilaria construens $f$ & (Ehrenberg) Grunow & Staurosira construens (172001) \\
\hline
\end{tabular}


Appendix B. Diatom species names and authorities according to Krammer \& Lange-Bertlot (1991)

\begin{tabular}{|c|c|c|}
\hline Species & Authority & Updated Species Name \\
\hline Fragilaria construens $f$ venter & $\begin{array}{l}\text { (Ehrenberg) } \\
\text { Hustedt }\end{array}$ & $\begin{array}{l}\text { Staurosira construens var. venter } \\
\text { (172006) }\end{array}$ \\
\hline Fragilaria construens $f$. & (Ehrenberg) & Staurosira construens var. binodis \\
\hline $\begin{array}{l}\text { binodis } \\
\text { Fragilaria delicatissima }\end{array}$ & $\begin{array}{l}\text { Grunow } \\
\text { (W Smith) Lange- } \\
\text { Bertalot }\end{array}$ & $\begin{array}{l}(172005) \\
-\end{array}$ \\
\hline Fragilaria elliptica & Schumann & Pseudostaurosira elliptica (73025) \\
\hline Fragilaria exigua & Grunow & $\begin{array}{l}\text { Staurosira construens var. exigua } \\
\text { (172022) }\end{array}$ \\
\hline Fragilaria fasciculata & $\begin{array}{l}\text { (Agargh) Lange- } \\
\text { Bertalot }\end{array}$ & Tabularia fasciculata (200002) \\
\hline Fragilaria lapponica & Grunow & Staurosirella lapponica (175002) \\
\hline $\begin{array}{l}\text { Fragilaria leptostauron var. } \\
\text { rhomboides }\end{array}$ & Grunow & $\begin{array}{l}\text { Staurosirella leptostauron var. } \\
\text { rhomboides (175017) }\end{array}$ \\
\hline Fragilaria pinnata & Ehrenberg & Staurosirella pinnata (175005) \\
\hline Fragilaria pseudoconstruens & Marciniak & $\begin{array}{l}\text { Pseudostaurosira pseudoconstruens } \\
\text { (73002) }\end{array}$ \\
\hline Frustulia rhomboides & (Ehrenberg) deToni & Frustulia krammeri (35039) \\
\hline Gomphonema acuminatum & Ehrenberg & Gomphonema acuminatum (37001) \\
\hline Gomphonema angustatum & Kützing & Gomphonema angustatum (37003) \\
\hline Gomphonema olivaceum & $\begin{array}{l}\text { (Hornemann) } \\
\text { Brebisson }\end{array}$ & Gomphonema olivaceum (37065) \\
\hline Gomphonema parvulum & Kützing & Gomphonema parvulum (37010) \\
\hline $\begin{array}{l}\text { Gomphonema } \\
\text { pseudosphaerophorum }\end{array}$ & Kobayasi & - \\
\hline Gomphonema rhombicum & Fricke & Gomphonema rhombicum (37080) \\
\hline Gomphonema sarcophagus & Gregory & Gomphonema sarcophagus (37152) \\
\hline Gomphonema truncatum & Ehrenberg & Gomphonema truncatum (37022) \\
\hline Navicula absoluta & Hustedt & Navicula absoluta (46494) \\
\hline Navicula cocconeiformis & Gregory & Cavinula cocconeiformis (195001) \\
\hline Navicula cryptocephala & Kützing & Navicula cryptocephala (46014) \\
\hline Navicula difficillima & Hustedt & Navicula difficillima (46017) \\
\hline Navicula elginensis & (Gregory) Ralfs & Placoneis elginensis (194005) \\
\hline Navicula halophila & (Grunow) Cleve & Craticula halophila (21005) \\
\hline Navicula levanderii & Hustedt & - \\
\hline Navicula mediocris & Krasske & Chamaepinnularia mediocris (212005) \\
\hline Navicula polyonca & Brebisson & Pinnularia polyonca (52087) \\
\hline Navicula prominula & AWF Schmidt & - \\
\hline Navicula pseudobryophila & Hustedt & Navicula pseudobryophila (46807) \\
\hline Navicula pseudoscutiformis & Hustedt & Cavinula pseudoscutiformis (195003) \\
\hline Navicula pseudoventralis & Hustedt & Navicula pseudoventralis (46166) \\
\hline Navicula pupula & Kützing & Sellaphora pupula (170006) \\
\hline Navicula riparia & Hustedt & Craticula riparia (21016) \\
\hline Navicula schmassmannii & Hustedt & Navicula schmassmannii (46066) \\
\hline
\end{tabular}


Appendix B. Diatom species names and authorities according to Krammer \& Lange-Bertlot (1991)

\begin{tabular}{|c|c|c|}
\hline Species & Authority & Updated Species Name \\
\hline Navicula soehrensis & Krasske & $\begin{array}{l}\text { Chamaepinnularia soehrensis } \\
(212006)\end{array}$ \\
\hline Navicula striolata & $\begin{array}{l}\text { (Grunow) Lange- } \\
\text { Bertalot }\end{array}$ & Navicula striolata (93266) \\
\hline Navicula subrotundata & Hustedt & Navicula subrotundata (46079) \\
\hline Navicula trivalis & Lange-Bertalot & - \\
\hline Navicula viridula & Kützing & Navicula viridula (46408) \\
\hline Neidium affine & (Ehrenberg) Pfizer & Neidium affine (47001) \\
\hline Neidium ampliatum & (Ehrenberg) Krammer & Neidium ampliatum (47066) \\
\hline Neidium dubium & (Ehrenberg) Cleve & Neidium dubium (47011) \\
\hline Neidium hitchcockii & (Ehrenberg) Cleve & Neidium hitchcockii (47028) \\
\hline Neidium iridis & (Ehrenberg) Cleve & Neidium iridis (47014) \\
\hline Neidium Septentrionalis & Cleve-Euler & Neidium septentrionalis (47110) \\
\hline Nitzschia angustata & Grunow & Nitzschia angustata (48093) \\
\hline Nitzschia behrei & Hustedt & Nitzschia behrei (48585) \\
\hline Nitzschia diversa & Hustedt & Nitzschia diversa (48411) \\
\hline Nitzschia elegans & Hustedt & Nitzschia elegans (48010) \\
\hline Nitzschia fonticola & Grunow & Nitzschia fonticola (48011) \\
\hline Nitzschia gisela & Lange-Bertalot & Nitzschia gisela (48624) \\
\hline Nitzschia graciliformis & Lange-Bertalot \& Simonsen & Nitzschia graciliformis (48119) \\
\hline Nitzschia gracilis & Hantzsch & Nitzschia gracilis (48015) \\
\hline Nitzschia recta & Hantzsch & Nitzschia recta (48029) \\
\hline Nitzschia tropica & Hustedt & Nitzschia tropica (48045) \\
\hline Pinnularia alpina & W Smith & Pinnularia alpina (52807) \\
\hline Pinnularia appendiculata & (Agargh) Cleve & $\begin{array}{l}\text { Pinnularia appendiculata } \\
\text { (52009) }\end{array}$ \\
\hline Pinnularia borealis & Ehrenberg & Pinnularia borealis (52013) \\
\hline Pinnularia braunii & (Grunow) Cleve & Pinnularia brauniana (103001) \\
\hline Pinnularia divergens & W Smith & Pinnularia divergens (52025) \\
\hline Pinnularia episcopalis & Cleve & - \\
\hline Pinnularia gibba & Ehrenberg & Pinnularia gibba (52159) \\
\hline Pinnularia interrupta & W Smith & Pinnularia interrupta (52194) \\
\hline Pinnularia karelica & Cleve & - \\
\hline Pinnularia microstauron & (Ehrenberg) Cleve & Pinnularia microstauron (52045) \\
\hline Pinnularia noblis & Ehrenberg & Pinnularia nobilis (103038) \\
\hline Pinnularia nodsa & Ehrenberg & Pinnularia nodosa (52048) \\
\hline Pinnularia polyonca & Brebisson & Pinnularia polyonca (52087) \\
\hline Pinnularia pulchra & Østrup & Pinnularia pulchra (52801) \\
\hline Pinnularia Subcapitata & Gregory & Pinnularia subcapitata (52059) \\
\hline Pinnularia subrostrata & (A Cleve) Cleve-Euler & Pinnularia subrostrata (52184) \\
\hline $\begin{array}{l}\text { Pinnularia } \\
\text { superdiverdentissima }\end{array}$ & Chaumont \& Germain & - \\
\hline Pinnularia viridis & (Nitzsch) Ehrenberg & Pinnularia viridis (52071) \\
\hline Stauroneis acuta & W Smith & Stauroneis acuta (62036) \\
\hline
\end{tabular}




\begin{tabular}{lll}
\hline Species & Authority & Updated Species Name \\
\hline Stauroneis anceps & Ehrenberg & Stauroneis anceps (62002) \\
Stauroneis gracillima & Hustedt & Nupela gracillima (92026) \\
Stauroneis javanica & (Grunow) Cleve & Stauroneis cf. javanica (62045) \\
Stauroneis phoenicenteron & (Nitzsch) Ehrenberg & Stauroneis phoenicenteron (62015) \\
Stauroneis producta & Grunow & Stauroneis producta (62017) \\
Stauroneis prominula & (Grunow) Hustedt & Stauroneis prominula (62069) \\
Stauroneis schimanskii & Krammer & Stauroneis cf. schimanskii (62127) \\
Stauroneis thermicola & (Petersen) Lund & Stauroneis thermicola (62040) \\
Stenopterobia anceps & (Lewis) Brebisson & Stenopterobia anceps (63003) \\
Stenopterobia delicatissima & (Lewis) Brebisson & Stenopterobia delicatissima (63007) \\
Surirella amphioxys & W Smith & Surirella amphioxys (65069) \\
Surirella angusta & Kützing & Surirella angusta (65002) \\
Surirella elegans & Ehrenberg & Surirella elegans (65072) \\
Surirella gracilis & Grunow & Surirella gracilis (65013) \\
Surirella linearis & W Smith & Surirella linearis (65014) \\
Tabellaria binalis & (Ehrenberg) Grunow & Oxyneis binalis (9107001) \\
Tabellaria fenestrata & (Lyngbye) Kützing & Tabellaria fenestrata (67002) \\
Tabellaria flocculosa & (Roth) Kützing & Tabellaria flocculosa (67004) \\
Tetracyclus glans & (Ehrenberg) Mills & Tetracyclus glans (71006) \\
Tetracyclus lacustris & Ralfs & Tetracyclus lacustris (71003) \\
& &
\end{tabular}




\section{Appendix C. Comprehensive diatom counts for the Danny's Lake sediment core}

Updated species names and NADED ID numbers (in brackets) according to Academy of Natural Sciences and collaborators (2011-2013) 


\begin{tabular}{|c|c|c|c|c|c|c|c|}
\hline \multirow[b]{2}{*}{ Updated Species Name } & \multicolumn{7}{|c|}{ Depth (cm) } \\
\hline & 0.5 & 0.7 & 1.4 & 1.7 & 2.3 & 2.5 & 3.2 \\
\hline \multicolumn{8}{|l|}{ Achnanthes imperfecta (2051) } \\
\hline Achnanthes levanderi (2022) & 7 & 5 & 3 & 1 & 3 & 4 & 5 \\
\hline Achnanthes pergalli & & & & & & 1 & \\
\hline Achnanthes pseudoswazi (2206) & & & & & 1 & & \\
\hline \multicolumn{8}{|l|}{ Achnanthes trinodis (2109) } \\
\hline Achnanthidium minutissimum (1010) & 23 & 13 & 17 & 4 & 34 & 8 & 18 \\
\hline \multicolumn{8}{|l|}{ Achnanthidium semiapertum (1028) } \\
\hline \multicolumn{8}{|l|}{ Amphipleura lindheimerii } \\
\hline \multicolumn{8}{|l|}{ Amphora copulata (7075) } \\
\hline Amphora ovalis (7001) & & & & 1 & 1 & & \\
\hline Aulacoseira alpigena (10028) & 105 & 106 & 175 & 200 & 118 & 150 & 188 \\
\hline Aulacoseira ambigua (10008) & 1 & & & 2 & 1 & & \\
\hline \multicolumn{8}{|l|}{ Aulacoseira canadensis (10003) } \\
\hline \multicolumn{8}{|l|}{ Aulacoseira crassipunctata (10001) } \\
\hline Aulacoseira distans (10009) & 31 & 24 & 25 & 10 & 50 & 14 & 23 \\
\hline Aulacoseira granulata (10018) & & & & & & 1 & \\
\hline \multicolumn{8}{|l|}{ Aulacoseira italica (10019) } \\
\hline Aulacoseira lacustris (10060) & 21 & 59 & 17 & 33 & 13 & 49 & 27 \\
\hline \multicolumn{8}{|l|}{ Aulacoseira lirata (10012) } \\
\hline \multicolumn{8}{|l|}{ Aulacoseira muzzanensis (10031) } \\
\hline Aulacoseira perglabra (10006) & 6 & 9 & 28 & 10 & 3 & 4 & 19 \\
\hline Aulacoseira subarctica (10015) & & 2 & & & 4 & 1 & \\
\hline Aulacoseira tethera (10033) & & & & & 3 & 1 & \\
\hline Aulacoseira valida (10029) & 1 & & & & & & \\
\hline \multicolumn{8}{|l|}{ Bacillaria paradoxa (76001) } \\
\hline Brachysira brebissonii (18005) & 6 & 6 & 7 & 9 & 1 & 9 & 11 \\
\hline Brachysira microcephala (18013) & 2 & & & 1 & 2 & 1 & \\
\hline \multicolumn{8}{|l|}{ Caloneis alpestris (12025) } \\
\hline \multicolumn{8}{|l|}{ Caloneis lauta (12026) } \\
\hline \multicolumn{8}{|l|}{ Caloneis permagna (12030) } \\
\hline \multicolumn{8}{|l|}{ Caloneis silicula (12010) } \\
\hline \multicolumn{8}{|l|}{ Caloneis tenuis (12013) } \\
\hline \multicolumn{8}{|l|}{ Caloneis thermalis (12054) } \\
\hline \multicolumn{8}{|l|}{ Caloneis undulata (12022) } \\
\hline \multicolumn{8}{|l|}{ Caloneis westii (12056) } \\
\hline Cavinula cocconeiformis (195001) & 1 & 1 & 4 & & 4 & 2 & 1 \\
\hline Cavinula pseudoscutiformis (195003) & 5 & 1 & 2 & & 3 & 2 & 2 \\
\hline
\end{tabular}




\begin{tabular}{|c|c|c|c|c|c|c|c|}
\hline \multirow[b]{2}{*}{ Updated Species Name } & \multicolumn{7}{|c|}{ Depth (cm) } \\
\hline & 0.5 & 0.7 & 1.4 & 1.7 & 2.3 & 2.5 & 3.2 \\
\hline Chamaepinnularia mediocris (212005) & & 1 & & & & & \\
\hline \multicolumn{8}{|l|}{ Chamaepinnularia soehrensis (212006) } \\
\hline \multicolumn{8}{|l|}{ Cocconeis placentula (16004) } \\
\hline Craticula halophila (21005) & & & & & 1 & & \\
\hline \multicolumn{8}{|l|}{ Craticula riparia (21016) } \\
\hline Cyclotella comensis (20023) & & & & & 1 & & 1 \\
\hline \multicolumn{8}{|l|}{ Cyclotella krammeri (20083) } \\
\hline Cyclotella ocellata (20009) & 26 & 26 & 27 & 26 & 30 & 34 & 23 \\
\hline Cyclotella rossii (20019) & 1 & 1 & & 2 & & 1 & 1 \\
\hline Cyclotella tripartita (20085) & & 6 & 6 & 1 & 5 & 10 & 6 \\
\hline \multicolumn{8}{|l|}{ Cymbella affinis (23073) } \\
\hline \multicolumn{8}{|l|}{ Cymbella amphicephala (23001) } \\
\hline \multicolumn{8}{|l|}{ Cymbella cesatii (23004) } \\
\hline \multicolumn{8}{|l|}{ Cymbella cistula (23005) } \\
\hline \multicolumn{8}{|l|}{ Cymbella helvetica (23099) } \\
\hline \multicolumn{8}{|l|}{ Cymbella heteropleura (23100) } \\
\hline \multicolumn{8}{|l|}{ Cymbella lapponica (23116) } \\
\hline \multicolumn{8}{|l|}{ Cymbella rupicola (23020) } \\
\hline \multicolumn{8}{|l|}{ Cymbella schimanskii } \\
\hline Cymbella sileiaca & 3 & 1 & 4 & 4 & 3 & 6 & 2 \\
\hline \multicolumn{8}{|l|}{ Cymbella tumidula (23082) } \\
\hline \multicolumn{8}{|l|}{ Cymbella tynnii (47141) } \\
\hline \multicolumn{8}{|l|}{ Cymbopleura angustata (190013) } \\
\hline Cymbopleura cuspidata (190001) & & & & & & 1 & \\
\hline \multicolumn{8}{|l|}{ Cymbopleura subaequalis (190017) } \\
\hline Denticula elegans (25001) & & & & & & 1 & \\
\hline \multicolumn{8}{|l|}{ Denticula keutzingii } \\
\hline \multicolumn{8}{|l|}{ Diatoma mesodon (27002) } \\
\hline \multicolumn{8}{|l|}{ Diatoma vulgaris (27013) } \\
\hline \multicolumn{8}{|l|}{ Diploneis boldtiana (30012) } \\
\hline Diploneis elliptica (30001) & & & & 1 & & & \\
\hline \multicolumn{8}{|l|}{ Diploneis finnica (30002) } \\
\hline Diploneis marginestriata (30003) & & & 1 & 1 & & & \\
\hline \multicolumn{8}{|l|}{ Diploneis ovalis (30009) } \\
\hline Diploneis parma (30014) & & & & 1 & & 1 & \\
\hline Discostella pseudostelligera (2506002) & 15 & 11 & 1 & 10 & 3 & 15 & 8 \\
\hline Discostella stelligera (2506003) & 10 & & 10 & 4 & 2 & 3 & 4 \\
\hline
\end{tabular}




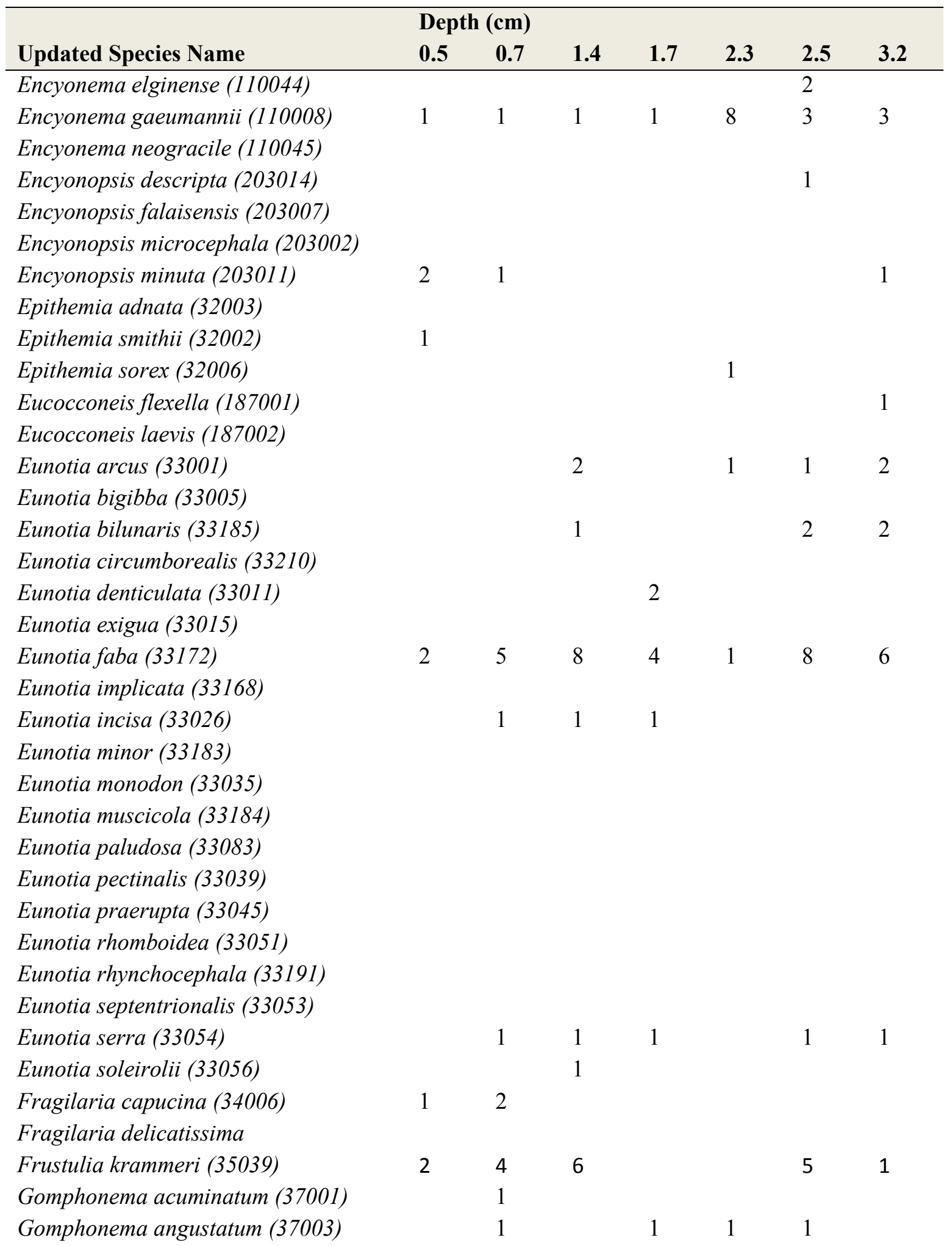




\begin{tabular}{|c|c|c|c|c|c|c|c|}
\hline \multirow[b]{2}{*}{ Updated Species Name } & \multicolumn{7}{|c|}{ Depth (cm) } \\
\hline & 0.5 & 0.7 & 1.4 & 1.7 & 2.3 & 2.5 & 3.2 \\
\hline \multicolumn{8}{|l|}{ Gomphonema olivaceum (37065) } \\
\hline \multicolumn{8}{|l|}{ Gomphonema parvulum (37010) } \\
\hline \multicolumn{8}{|l|}{ Gomphonema pseudosphaerophorum } \\
\hline Gomphonema rhombicum (37080) & 1 & & & & & & \\
\hline Gomphonema sarcophagus (37152) & & 1 & & & & 1 & \\
\hline \multicolumn{8}{|l|}{ Gomphonema truncatum (37022) } \\
\hline \multicolumn{8}{|l|}{ Karayevia laterostrata (125002) } \\
\hline \multicolumn{8}{|l|}{ Karayevia ploenensis (125008) } \\
\hline Karayevia suchlandtii (125009) & 5 & 12 & 4 & & & 1 & 2 \\
\hline \multicolumn{8}{|l|}{ Navicula absoluta (46494) } \\
\hline Navicula cryptocephala (46014) & 2 & 1 & 2 & & 1 & 1 & \\
\hline \multicolumn{8}{|l|}{ Navicula difficillima (46017) } \\
\hline \multicolumn{8}{|l|}{ Navicula levanderii } \\
\hline \multicolumn{8}{|l|}{ Navicula prominula } \\
\hline \multicolumn{8}{|l|}{ Navicula pseudobryophila (46807) } \\
\hline \multicolumn{8}{|l|}{ Navicula pseudoventralis (46166) } \\
\hline Navicula schmassmannii (46066) & 2 & 1 & 4 & & & & \\
\hline \multicolumn{8}{|l|}{ Navicula striolata (93266) } \\
\hline \multicolumn{8}{|l|}{ Navicula subrotundata (46079) } \\
\hline \multicolumn{8}{|l|}{ Navicula trivalis } \\
\hline Navicula viridula (46408) & & & & & & 1 & \\
\hline \multicolumn{8}{|l|}{ Neidium affine (47001) } \\
\hline \multicolumn{8}{|l|}{ Neidium ampliatum (47066) } \\
\hline Neidium dubium (47011) & & & & 1 & & 1 & \\
\hline \multicolumn{8}{|l|}{ Neidium hitchcockii (47028) } \\
\hline \multicolumn{8}{|l|}{ Neidium iridis (47014) } \\
\hline \multicolumn{8}{|l|}{ Neidium septentrionalis (47110) } \\
\hline Nitzschia angustata (48093) & & 1 & & & & & \\
\hline Nitzschia behrei (48585) & & & 1 & & & & \\
\hline \multicolumn{8}{|l|}{ Nitzschia diversa (48411) } \\
\hline \multicolumn{8}{|l|}{ Nitzschia elegans (48010) } \\
\hline Nitzschia fonticola (48011) & 12 & 12 & 8 & 7 & 7 & 10 & 7 \\
\hline \multicolumn{8}{|l|}{ Nitzschia gisela (48624) } \\
\hline \multicolumn{8}{|l|}{ Nitzschia graciliformis (48119) } \\
\hline Nitzschia gracilis (48015) & & & & & & & \\
\hline Nitzschia recta (48029) & & & & & & & \\
\hline Nitzschia tropica (48045) & & & & & & & \\
\hline
\end{tabular}




\begin{tabular}{|c|c|c|c|c|c|c|c|}
\hline \multirow[b]{2}{*}{ Updated Species Name } & \multicolumn{7}{|c|}{ Depth (cm) } \\
\hline & 0.5 & 0.7 & 1.4 & 1.7 & 2.3 & 2.5 & 3.2 \\
\hline \multicolumn{8}{|l|}{ Nupela gracillima (92026) } \\
\hline \multicolumn{8}{|l|}{ Oxyneis binalis (9107001) } \\
\hline \multicolumn{8}{|l|}{ Pinnularia alpina (52807) } \\
\hline \multicolumn{8}{|l|}{ Pinnularia appendiculata (52009) } \\
\hline Pinnularia borealis (52013) & & 1 & & & & & \\
\hline \multicolumn{8}{|l|}{ Pinnularia brauniana (103001) } \\
\hline \multicolumn{8}{|l|}{ Pinnularia divergens (52025) } \\
\hline \multicolumn{8}{|l|}{ Pinnularia episcopalis } \\
\hline \multicolumn{8}{|l|}{ Pinnularia gibba (52159) } \\
\hline \multicolumn{8}{|l|}{ Pinnularia interrupta (52194) } \\
\hline \multicolumn{8}{|l|}{ Pinnularia karelica } \\
\hline Pinnularia microstauron (52045) & & & & 2 & & & \\
\hline \multicolumn{8}{|l|}{ Pinnularia nobilis (103038) } \\
\hline Pinnularia nodosa (52048) & 1 & & & & & 1 & \\
\hline \multicolumn{8}{|l|}{ Pinnularia polyonca (52087) } \\
\hline \multicolumn{8}{|l|}{ Pinnularia polyonca (52087) } \\
\hline \multicolumn{8}{|l|}{ Pinnularia pulchra (52801) } \\
\hline Pinnularia subcapitata (52059) & & & 4 & 3 & & & 1 \\
\hline \multicolumn{8}{|l|}{ Pinnularia subrostrata (52184) } \\
\hline \multicolumn{8}{|l|}{ Pinnularia superdiverdentissima } \\
\hline Pinnularia viridis (52071) & 1 & & & 1 & & & \\
\hline \multicolumn{8}{|l|}{ Placoneis elginensis (194005) } \\
\hline \multicolumn{8}{|l|}{ Planothidium joursacense (155016) } \\
\hline \multicolumn{8}{|l|}{ Planothidium oestrupii (155026) } \\
\hline \multicolumn{8}{|l|}{ Platessa holsatica (2508002) } \\
\hline Psammothidium curtissimum (186021) & 7 & 2 & & & & & 2 \\
\hline \multicolumn{8}{|l|}{ Psammothidium didymum (186012) } \\
\hline \multicolumn{8}{|l|}{ Psammothidium helveticum (186003) } \\
\hline Psammothidium ventralis (186009) & 1 & & & & & & \\
\hline Pseudostaurosira brevistriata (73001) & 37 & 18 & 17 & 16 & 51 & 14 & 25 \\
\hline Pseudostaurosira elliptica (73025) & 5 & 5 & 1 & 3 & 8 & 3 & 2 \\
\hline Pseudostaurosira pseudoconstruens (73002) & 5 & & 3 & 1 & 12 & 2 & 1 \\
\hline Puncticulata bodanica (208004) & 2 & 1 & 4 & 2 & 2 & 5 & 1 \\
\hline \multicolumn{8}{|l|}{ Reimeria sinuata (55002) } \\
\hline Rossithidium nodosum (189006) & 3 & & & & & & \\
\hline Rossithidium pusillum (189003) & 7 & 3 & 5 & 1 & 7 & 1 & \\
\hline Sellaphora pupula (170006) & & 1 & & 1 & 4 & 2 & \\
\hline
\end{tabular}




\begin{tabular}{|c|c|c|c|c|c|c|c|}
\hline \multirow[b]{2}{*}{ Updated Species Name } & \multicolumn{7}{|c|}{ Depth (cm) } \\
\hline & 0.5 & $\mathbf{0 . 7}$ & 1.4 & 1.7 & 2.3 & 2.5 & 3.2 \\
\hline \multicolumn{8}{|l|}{ Stauroneis acuta (62036) } \\
\hline \multicolumn{8}{|l|}{ Stauroneis anceps (62002) } \\
\hline \multicolumn{8}{|l|}{ Stauroneis cf. javanica (62045) } \\
\hline \multicolumn{8}{|l|}{ Stauroneis cf. schimanskii (62127) } \\
\hline Stauroneis phoenicenteron (62015) & & & 2 & & & & \\
\hline Stauroneis producta (62017) & & 2 & & & & 1 & \\
\hline Stauroneis prominula (62069) & 1 & & 2 & 1 & & & \\
\hline \multicolumn{8}{|l|}{ Stauroneis thermicola (62040) } \\
\hline Staurosira construens (172001) & & & & & 1 & & \\
\hline Staurosira construens var. binodis (172005) & 15 & 7 & 8 & 15 & 7 & 10 & 3 \\
\hline Staurosira construens var. exigua (172022) & 38 & 48 & 31 & 25 & 32 & 35 & 25 \\
\hline Staurosira construens var. venter (172006) & 18 & 8 & 5 & 3 & 18 & 1 & 7 \\
\hline \multicolumn{8}{|l|}{ Staurosirella lapponica (175002) } \\
\hline Staurosirella leptostauron var. rhomboides (175017) & 2 & 4 & 6 & & & 5 & 1 \\
\hline Staurosirella pinnata (175005) & 3 & 3 & 1 & 1 & 24 & 2 & 4 \\
\hline \multicolumn{8}{|l|}{ Stenopterobia anceps (63003) } \\
\hline \multicolumn{8}{|l|}{ Stenopterobia delicatissima (63007) } \\
\hline \multicolumn{8}{|l|}{ Surirella amphioxys (65069) } \\
\hline \multicolumn{8}{|l|}{ Surirella angusta (65002) } \\
\hline \multicolumn{8}{|l|}{ Surirella elegans (65072) } \\
\hline \multicolumn{8}{|l|}{ Surirella gracilis (65013) } \\
\hline Surirella linearis (65014) & & & 2 & & & & \\
\hline Tabellaria fenestrata (67002) & & 4 & 1 & 1 & & 2 & \\
\hline Tabellaria flocculosa (67004) & 6 & 7 & 5 & 1 & 5 & 2 & 7 \\
\hline Tabularia fasciculata (200002) & & & & & 1 & & \\
\hline Tetracyclus glans (71006) & 2 & & & 1 & & 1 & \\
\hline \multicolumn{8}{|l|}{ Tetracyclus lacustris (71003) } \\
\hline "Total chrysophyte cysts per slice & 25 & 25 & 12 & 1110 & 28 & 22 & 78 \\
\hline Total diatom counts per slice & 449 & 431 & 464 & 417 & 478 & 445 & 444 \\
\hline Total microspheres per slice & 358 & & 1180 & & 460 & & 600 \\
\hline
\end{tabular}




\begin{tabular}{|c|c|c|c|c|c|c|c|}
\hline \multirow[b]{2}{*}{ Updated Species Name } & \multicolumn{7}{|c|}{ Depth (cm) } \\
\hline & 3.4 & 4.1 & 4.3 & 5.0 & 5.2 & 5.9 & 6.1 \\
\hline \multicolumn{8}{|l|}{ Achnanthes imperfecta (2051) } \\
\hline Achnanthes levanderi (2022) & 1 & 8 & 3 & 4 & & 5 & 3 \\
\hline \multicolumn{8}{|l|}{ Achnanthes pergalli } \\
\hline Achnanthes pseudoswazi (2206) & & 2 & & & & & \\
\hline \multicolumn{8}{|l|}{ Achnanthes trinodis (2109) } \\
\hline Achnanthidium minutissimum (1010) & 6 & 17 & 7 & 13 & & 9 & 15 \\
\hline \multicolumn{8}{|l|}{ Achnanthidium semiapertum (1028) } \\
\hline \multicolumn{8}{|l|}{ Amphipleura lindheimerii } \\
\hline \multicolumn{8}{|l|}{ Amphora copulata (7075) } \\
\hline Amphora ovalis (7001) & & & 1 & & 1 & & 1 \\
\hline Aulacoseira alpigena (10028) & 190 & 106 & 116 & 111 & 89 & 200 & 139 \\
\hline Aulacoseira ambigua (10008) & & & & 1 & & & \\
\hline \multicolumn{8}{|l|}{ Aulacoseira canadensis (10003) } \\
\hline Aulacoseira crassipunctata (10001) & & & & & & 1 & \\
\hline Aulacoseira distans (10009) & 13 & 38 & 34 & 20 & 22 & 31 & 20 \\
\hline \multicolumn{8}{|l|}{ Aulacoseira granulata (10018) } \\
\hline \multicolumn{8}{|l|}{ Aulacoseira italica (10019) } \\
\hline Aulacoseira lacustris (10060) & 34 & 28 & 56 & 34 & 60 & 30 & 46 \\
\hline \multicolumn{8}{|l|}{ Aulacoseira lirata (10012) } \\
\hline \multicolumn{8}{|l|}{ Aulacoseira muzzanensis (10031) } \\
\hline Aulacoseira perglabra (10006) & 11 & 8 & 7 & 7 & 13 & 8 & 8 \\
\hline Aulacoseira subarctica (10015) & 1 & 7 & & 1 & & 1 & \\
\hline Aulacoseira tethera (10033) & & & 1 & & & 1 & \\
\hline \multicolumn{8}{|l|}{ Aulacoseira valida (10029) } \\
\hline \multicolumn{8}{|l|}{ Bacillaria paradoxa (76001) } \\
\hline Brachysira brebissonii (18005) & 8 & 11 & 11 & 12 & 30 & 7 & 8 \\
\hline Brachysira microcephala (18013) & & 1 & 1 & & & 1 & \\
\hline \multicolumn{8}{|l|}{ Caloneis alpestris (12025) } \\
\hline Caloneis lauta (12026) & & & & & 1 & & \\
\hline \multicolumn{8}{|l|}{ Caloneis permagna (12030) } \\
\hline \multicolumn{8}{|l|}{ Caloneis silicula (12010) } \\
\hline \multicolumn{8}{|l|}{ Caloneis tenuis (12013) } \\
\hline \multicolumn{8}{|l|}{ Caloneis thermalis (12054) } \\
\hline \multicolumn{8}{|l|}{ Caloneis undulata (12022) } \\
\hline \multicolumn{8}{|l|}{ Caloneis westii (12056) } \\
\hline Cavinula cocconeiformis (195001) & & 1 & 2 & 4 & 1 & & \\
\hline Cavinula pseudoscutiformis (195003) & 1 & 2 & 4 & 1 & & & 5 \\
\hline
\end{tabular}




\begin{tabular}{|c|c|c|c|c|c|c|c|}
\hline \multirow[b]{2}{*}{ Updated Species Name } & \multicolumn{7}{|c|}{ Depth (cm) } \\
\hline & 3.4 & 4.1 & 4.3 & 5.0 & 5.2 & 5.9 & 6.1 \\
\hline Chamaepinnularia mediocris (212005) & & & 1 & & & & \\
\hline \multicolumn{8}{|l|}{ Chamaepinnularia soehrensis (212006) } \\
\hline \multicolumn{8}{|l|}{ Cocconeis placentula (16004) } \\
\hline Craticula halophila (21005) & 1 & & & & & & \\
\hline \multicolumn{8}{|l|}{ Craticula riparia (21016) } \\
\hline Cyclotella comensis (20023) & & & 1 & & 1 & & \\
\hline \multicolumn{8}{|l|}{ Cyclotella krammeri (20083) } \\
\hline Cyclotella ocellata (20009) & 29 & 28 & 35 & 32 & 40 & 26 & 34 \\
\hline Cyclotella rossii (20019) & 2 & 5 & 3 & 4 & 3 & 2 & 1 \\
\hline Cyclotella tripartita (20085) & 2 & 6 & 9 & 7 & 14 & 6 & 7 \\
\hline \multicolumn{8}{|l|}{ Cymbella affinis (23073) } \\
\hline \multicolumn{8}{|l|}{ Cymbella amphicephala (23001) } \\
\hline \multicolumn{8}{|l|}{ Cymbella cesatii (23004) } \\
\hline \multicolumn{8}{|l|}{ Cymbella cistula (23005) } \\
\hline \multicolumn{8}{|l|}{ Cymbella helvetica (23099) } \\
\hline \multicolumn{8}{|l|}{ Cymbella heteropleura (23100) } \\
\hline \multicolumn{8}{|l|}{ Cymbella lapponica (23116) } \\
\hline Cymbella rupicola (23020) & & & 1 & & & & \\
\hline \multicolumn{8}{|l|}{ Cymbella schimanskii } \\
\hline Cymbella sileiaca & & 2 & 2 & 2 & & 7 & 2 \\
\hline \multicolumn{8}{|l|}{ Cymbella tumidula (23082) } \\
\hline \multicolumn{8}{|l|}{ Cymbella tynnii (47141) } \\
\hline \multicolumn{8}{|l|}{ Cymbopleura angustata (190013) } \\
\hline Cymbopleura cuspidata (190001) & & & 1 & & & & \\
\hline \multicolumn{8}{|l|}{ Cymbopleura subaequalis (190017) } \\
\hline \multicolumn{8}{|l|}{ Denticula elegans (25001) } \\
\hline \multicolumn{8}{|l|}{ Denticula keutzingii } \\
\hline \multicolumn{8}{|l|}{ Diatoma mesodon (27002) } \\
\hline \multicolumn{8}{|l|}{ Diatoma vulgaris (27013) } \\
\hline \multicolumn{8}{|l|}{ Diploneis boldtiana (30012) } \\
\hline \multicolumn{8}{|l|}{ Diploneis elliptica (30001) } \\
\hline \multicolumn{8}{|l|}{ Diploneis finnica (30002) } \\
\hline Diploneis marginestriata (30003) & & 1 & 1 & 3 & 1 & & \\
\hline \multicolumn{8}{|l|}{ Diploneis ovalis (30009) } \\
\hline Diploneis parma (30014) & 1 & & & & 5 & & 1 \\
\hline Discostella pseudostelligera (2506002) & 7 & 11 & 14 & 16 & 8 & 10 & 10 \\
\hline Discostella stelligera (2506003) & 7 & 8 & 7 & 6 & & 1 & 5 \\
\hline
\end{tabular}




\begin{tabular}{|c|c|c|c|c|c|c|c|}
\hline \multirow[b]{2}{*}{ Updated Species Name } & \multicolumn{7}{|c|}{ Depth (cm) } \\
\hline & 3.4 & 4.1 & 4.3 & 5.0 & 5.2 & 5.9 & 6.1 \\
\hline Encyonema elginense (110044) & & & & & & & 1 \\
\hline Encyonema gaeumannii (110008) & 1 & & 3 & 1 & & & 1 \\
\hline \multicolumn{8}{|l|}{ Encyonema neogracile (110045) } \\
\hline Encyonopsis descripta (203014) & & & & & & 1 & \\
\hline \multicolumn{8}{|l|}{ Encyonopsis falaisensis (203007) } \\
\hline \multicolumn{8}{|l|}{ Encyonopsis microcephala (203002) } \\
\hline Encyonopsis minuta (203011) & & 2 & 1 & 7 & & & 4 \\
\hline \multicolumn{8}{|l|}{ Epithemia adnata (32003) } \\
\hline Epithemia smithii (32002) & 1 & & & & & & \\
\hline \multicolumn{8}{|l|}{ Epithemia sorex (32006) } \\
\hline Eucocconeis flexella (187001) & 1 & 1 & & & & & 1 \\
\hline \multicolumn{8}{|l|}{ Eucocconeis laevis (187002) } \\
\hline Eunotia arcus (33001) & 3 & & 1 & & 3 & 1 & \\
\hline Eunotia bigibba (33005) & & & 1 & & 1 & & \\
\hline Eunotia bilunaris (33185) & & 2 & & 1 & 2 & 1 & 2 \\
\hline \multicolumn{8}{|l|}{ Eunotia circumborealis (33210) } \\
\hline \multicolumn{8}{|l|}{ Eunotia denticulata (33011) } \\
\hline \multicolumn{8}{|l|}{ Eunotia exigua (33015) } \\
\hline Eunotia faba (33172) & 5 & 2 & 6 & 4 & 16 & 2 & 2 \\
\hline \multicolumn{8}{|l|}{ Eunotia implicata (33168) } \\
\hline Eunotia incisa (33026) & & & & 1 & & & 1 \\
\hline \multicolumn{8}{|l|}{ Eunotia minor (33183) } \\
\hline Eunotia monodon (33035) & & & & & 1 & & \\
\hline \multicolumn{8}{|l|}{ Eunotia muscicola (33184) } \\
\hline \multicolumn{8}{|l|}{ Eunotia paludosa (33083) } \\
\hline \multicolumn{8}{|l|}{ Eunotia pectinalis (33039) } \\
\hline \multicolumn{8}{|l|}{ Eunotia praerupta (33045) } \\
\hline \multicolumn{8}{|l|}{ Eunotia rhomboidea (33051) } \\
\hline \multicolumn{8}{|l|}{ Eunotia rhynchocephala (33191) } \\
\hline Eunotia septentrionalis (33053) & 1 & & & & & & \\
\hline Eunotia serra (33054) & 1 & & 2 & 1 & & & 1 \\
\hline Eunotia soleirolii (33056) & & 1 & 1 & & 1 & & \\
\hline Fragilaria capucina (34006) & 1 & & & 2 & 1 & 1 & \\
\hline \multicolumn{8}{|l|}{ Fragilaria delicatissima } \\
\hline Frustulia krammeri (35039) & 1 & 2 & 3 & 3 & 4 & & 5 \\
\hline Gomphonema acuminatum (37001) & 1 & & & & 1 & & \\
\hline Gomphonema angustatum (37003) & 1 & & 2 & & & 1 & 1 \\
\hline
\end{tabular}




\begin{tabular}{|c|c|c|c|c|c|c|c|}
\hline \multirow[b]{2}{*}{ Updated Species Name } & \multicolumn{7}{|c|}{ Depth (cm) } \\
\hline & 3.4 & 4.1 & 4.3 & 5.0 & 5.2 & 5.9 & 6.1 \\
\hline \multicolumn{8}{|l|}{ Gomphonema olivaceum (37065) } \\
\hline \multicolumn{8}{|l|}{ Gomphonema parvulum (37010) } \\
\hline \multicolumn{8}{|l|}{ Gomphonema pseudosphaerophorum } \\
\hline \multicolumn{8}{|l|}{ Gomphonema rhombicum (37080) } \\
\hline Gomphonema sarcophagus (37152) & & & & & 1 & & \\
\hline \multicolumn{8}{|l|}{ Gomphonema truncatum (37022) } \\
\hline Karayevia laterostrata (125002) & & & 1 & & & & \\
\hline \multicolumn{8}{|l|}{ Karayevia ploenensis (125008) } \\
\hline Karayevia suchlandtii (125009) & & & & & & 1 & 3 \\
\hline \multicolumn{8}{|l|}{ Navicula absoluta (46494) } \\
\hline Navicula cryptocephala (46014) & & 1 & 1 & 1 & & 1 & \\
\hline \multicolumn{8}{|l|}{ Navicula difficillima (46017) } \\
\hline \multicolumn{8}{|l|}{ Navicula levanderii } \\
\hline \multicolumn{8}{|l|}{ Navicula prominula } \\
\hline \multicolumn{8}{|l|}{ Navicula pseudobryophila (46807) } \\
\hline \multicolumn{8}{|l|}{ Navicula pseudoventralis (46166) } \\
\hline Navicula schmassmannii (46066) & & 2 & & & & 1 & 1 \\
\hline \multicolumn{8}{|l|}{ Navicula striolata (93266) } \\
\hline Navicula subrotundata (46079) & & & & & & & 3 \\
\hline \multicolumn{8}{|l|}{ Navicula trivalis } \\
\hline \multicolumn{8}{|l|}{ Navicula viridula (46408) } \\
\hline \multicolumn{8}{|l|}{ Neidium affine (47001) } \\
\hline \multicolumn{8}{|l|}{ Neidium ampliatum (47066) } \\
\hline \multicolumn{8}{|l|}{ Neidium dubium (47011) } \\
\hline \multicolumn{8}{|l|}{ Neidium hitchcockii (47028) } \\
\hline \multicolumn{8}{|l|}{ Neidium iridis (47014) } \\
\hline \multicolumn{8}{|l|}{ Neidium septentrionalis (47110) } \\
\hline Nitzschia angustata (48093) & & 2 & & & & & \\
\hline \multicolumn{8}{|l|}{ Nitzschia behrei (48585) } \\
\hline \multicolumn{8}{|l|}{ Nitzschia diversa (48411) } \\
\hline Nitzschia elegans (48010) & 1 & & & & & & \\
\hline Nitzschia fonticola (48011) & 6 & 18 & 8 & 11 & 2 & 7 & 17 \\
\hline \multicolumn{8}{|l|}{ Nitzschia gisela (48624) } \\
\hline Nitzschia graciliformis (48119) & & & & & & & \\
\hline Nitzschia gracilis (48015) & & & & & & & \\
\hline Nitzschia recta (48029) & & & & & & & \\
\hline Nitzschia tropica (48045) & & & & & & & \\
\hline
\end{tabular}




\begin{tabular}{|c|c|c|c|c|c|c|c|}
\hline \multirow[b]{2}{*}{ Updated Species Name } & \multicolumn{7}{|c|}{ Depth (cm) } \\
\hline & 3.4 & 4.1 & 4.3 & 5.0 & 5.2 & 5.9 & 6.1 \\
\hline \multicolumn{8}{|l|}{ Nupela gracillima (92026) } \\
\hline \multicolumn{8}{|l|}{ Oxyneis binalis (9107001) } \\
\hline \multicolumn{8}{|l|}{ Pinnularia alpina (52807) } \\
\hline \multicolumn{8}{|l|}{ Pinnularia appendiculata (52009) } \\
\hline \multicolumn{8}{|l|}{ Pinnularia borealis (52013) } \\
\hline Pinnularia brauniana (103001) & & 1 & & & & & \\
\hline Pinnularia divergens (52025) & & & & & 2 & & \\
\hline \multicolumn{8}{|l|}{ Pinnularia episcopalis } \\
\hline \multicolumn{8}{|l|}{ Pinnularia gibba (52159) } \\
\hline Pinnularia interrupta (52194) & & & 1 & & 1 & & 1 \\
\hline \multicolumn{8}{|l|}{ Pinnularia karelica } \\
\hline \multicolumn{8}{|l|}{ Pinnularia microstauron (52045) } \\
\hline \multicolumn{8}{|l|}{ Pinnularia nobilis (103038) } \\
\hline Pinnularia nodosa (52048) & & & & 1 & & & \\
\hline \multicolumn{8}{|l|}{ Pinnularia polyonca (52087) } \\
\hline \multicolumn{8}{|l|}{ Pinnularia polyonca (52087) } \\
\hline \multicolumn{8}{|l|}{ Pinnularia pulchra (52801) } \\
\hline Pinnularia subcapitata (52059) & 1 & & & 3 & & & \\
\hline \multicolumn{8}{|l|}{ Pinnularia subrostrata (52184) } \\
\hline \multicolumn{8}{|l|}{ Pinnularia superdiverdentissima } \\
\hline Pinnularia viridis (52071) & & & 1 & & & & 1 \\
\hline \multicolumn{8}{|l|}{ Placoneis elginensis (194005) } \\
\hline \multicolumn{8}{|l|}{ Planothidium joursacense (155016) } \\
\hline \multicolumn{8}{|l|}{ Planothidium oestrupii (155026) } \\
\hline \multicolumn{8}{|l|}{ Platessa holsatica (2508002) } \\
\hline Psammothidium curtissimum (186021) & 1 & & & & & 1 & \\
\hline \multicolumn{8}{|l|}{ Psammothidium didymum (186012) } \\
\hline \multicolumn{8}{|l|}{ Psammothidium helveticum (186003) } \\
\hline Psammothidium ventralis (186009) & & & 1 & & & & 1 \\
\hline Pseudostaurosira brevistriata (73001) & 18 & 25 & 19 & 15 & 7 & 18 & 20 \\
\hline Pseudostaurosira elliptica (73025) & & 5 & 1 & 1 & & 5 & 6 \\
\hline Pseudostaurosira pseudoconstruens (73002) & 1 & 8 & 3 & 1 & & 5 & \\
\hline Puncticulata bodanica (208004) & 3 & 1 & 3 & 1 & 7 & 1 & 3 \\
\hline \multicolumn{8}{|l|}{ Reimeria sinuata (55002) } \\
\hline Rossithidium nodosum (189006) & & 1 & & 1 & & & \\
\hline Rossithidium pusillum (189003) & 4 & 6 & 3 & 3 & 4 & 3 & 4 \\
\hline Sellaphora pupula (170006) & 1 & 2 & 3 & 4 & & & 3 \\
\hline
\end{tabular}




\begin{tabular}{|c|c|c|c|c|c|c|c|}
\hline \multirow[b]{2}{*}{ Updated Species Name } & \multicolumn{7}{|c|}{ Depth (cm) } \\
\hline & 3.4 & 4.1 & 4.3 & 5.0 & 5.2 & 5.9 & 6.1 \\
\hline \multicolumn{8}{|l|}{ Stauroneis acuta (62036) } \\
\hline \multicolumn{8}{|l|}{ Stauroneis anceps (62002) } \\
\hline \multicolumn{8}{|l|}{ Stauroneis cf. javanica (62045) } \\
\hline \multicolumn{8}{|l|}{ Stauroneis cf. schimanskii (62127) } \\
\hline \multicolumn{8}{|l|}{ Stauroneis phoenicenteron (62015) } \\
\hline Stauroneis producta (62017) & 1 & 2 & & 2 & & 1 & 2 \\
\hline Stauroneis prominula (62069) & & & & & & 1 & \\
\hline \multicolumn{8}{|l|}{ Stauroneis thermicola (62040) } \\
\hline Staurosira construens (172001) & & & & 2 & & & \\
\hline Staurosira construens var. binodis (172005) & 9 & 10 & 10 & 14 & 9 & 9 & 4 \\
\hline Staurosira construens var. exigua (172022) & 13 & 25 & 44 & 30 & 35 & 24 & 38 \\
\hline Staurosira construens var. venter (172006) & 5 & 16 & 8 & 10 & 7 & 10 & 10 \\
\hline \multicolumn{8}{|l|}{ Staurosirella lapponica (175002) } \\
\hline Staurosirella leptostauron var. rhomboides (175017) & 1 & 2 & 3 & 3 & 4 & & 5 \\
\hline Staurosirella pinnata (175005) & & 9 & 3 & 3 & 1 & 5 & 3 \\
\hline \multicolumn{8}{|l|}{ Stenopterobia anceps (63003) } \\
\hline \multicolumn{8}{|l|}{ Stenopterobia delicatissima (63007) } \\
\hline Surirella amphioxys (65069) & & & & 1 & & & \\
\hline Surirella angusta (65002) & & & 1 & & & & \\
\hline \multicolumn{8}{|l|}{ Surirella elegans (65072) } \\
\hline \multicolumn{8}{|l|}{ Surirella gracilis (65013) } \\
\hline Surirella linearis (65014) & & 1 & 1 & & 1 & & \\
\hline Tabellaria fenestrata (67002) & 2 & 4 & 2 & 1 & 1 & 1 & 1 \\
\hline Tabellaria flocculosa (67004) & 7 & 11 & 6 & 11 & 5 & 3 & 5 \\
\hline \multicolumn{8}{|l|}{ Tabularia fasciculata (200002) } \\
\hline Tetracyclus glans (71006) & 2 & 1 & 1 & & 3 & & \\
\hline Tetracyclus lacustris (71003) & & & & & 1 & & \\
\hline "Total chrysophyte cysts per slice & 1110 & 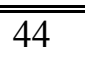 & 245 & 37 & 30 & $4 \overline{45}$ & 34 \\
\hline Total diatom counts per slice & 407 & 453 & 462 & 417 & 410 & 450 & 455 \\
\hline Total microspheres per slice & & 100 & & 295 & & 230 & \\
\hline
\end{tabular}




\begin{tabular}{|c|c|c|c|c|c|c|c|}
\hline & Dep & (cm) & & & & & \\
\hline Updated Species Name & 6.8 & 7.0 & 7.7 & 8.0 & 8.6 & 8.9 & 9.5 \\
\hline Achnanthes imperfecta (2051) & & & & & & & \\
\hline Achnanthes levanderi (2022) & 4 & 5 & 5 & 6 & 6 & 8 & 8 \\
\hline Achnanthes pergalli & & & & & & & \\
\hline Achnanthes pseudoswazi (2206) & & 1 & & & & 1 & 2 \\
\hline Achnanthes trinodis (2109) & & & & & & & \\
\hline Achnanthidium minutissimum (1010) & 23 & 15 & 25 & 13 & 11 & 20 & 16 \\
\hline Achnanthidium semiapertum (1028) & & & & & & & \\
\hline Amphipleura lindheimerii & & & & & & & \\
\hline Amphora copulata (7075) & & & & & & & \\
\hline Amphora ovalis (7001) & & 1 & & & 2 & 1 & 1 \\
\hline Aulacoseira alpigena (10028) & 107 & 154 & 176 & 113 & 160 & 108 & 100 \\
\hline Aulacoseira ambigua (10008) & & & 1 & 1 & & & 1 \\
\hline Aulacoseira canadensis (10003) & & & & 1 & & & \\
\hline Aulacoseira crassipunctata (10001) & & & & & & & \\
\hline Aulacoseira distans (10009) & 17 & 7 & 14 & 50 & 16 & 15 & 35 \\
\hline Aulacoseira granulata (10018) & & & & & & & \\
\hline Aulacoseira italica (10019) & & & & & & & \\
\hline Aulacoseira lacustris (10060) & 35 & 51 & 21 & 42 & 40 & 29 & 93 \\
\hline Aulacoseira lirata (10012) & & & & & & & \\
\hline Aulacoseira muzzanensis (10031) & & & & & & & 2 \\
\hline Aulacoseira perglabra (10006) & 4 & 2 & 10 & 12 & 14 & 3 & 9 \\
\hline Aulacoseira subarctica (10015) & 1 & 1 & 3 & & 2 & 1 & 1 \\
\hline Aulacoseira tethera (10033) & & & & 1 & 5 & & \\
\hline Aulacoseira valida (10029) & & & & & & & \\
\hline Bacillaria paradoxa (76001) & & & & & & & \\
\hline Brachysira brebissonii (18005) & 10 & 12 & 9 & 8 & 9 & 6 & 8 \\
\hline Brachysira microcephala (18013) & 1 & 2 & 1 & 1 & 1 & 3 & \\
\hline Caloneis alpestris (12025) & & & & & & & \\
\hline Caloneis lauta (12026) & & & & & & & \\
\hline Caloneis permagna (12030) & & & & & & & \\
\hline Caloneis silicula (12010) & & & & & & & \\
\hline Caloneis tenuis (12013) & & & & & & & \\
\hline Caloneis thermalis (12054) & & & & & & & \\
\hline Caloneis undulata (12022) & & & & & & & \\
\hline Caloneis westii (12056) & & & & & & & \\
\hline Cavinula cocconeiformis (195001) & 4 & 3 & 4 & 1 & 5 & 2 & \\
\hline Cavinula pseudoscutiformis (195003) & 4 & 4 & & 2 & 4 & 7 & 4 \\
\hline
\end{tabular}




\begin{tabular}{|c|c|c|c|c|c|c|c|}
\hline \multirow[b]{2}{*}{ Updated Species Name } & \multicolumn{7}{|c|}{ Depth (cm) } \\
\hline & 6.8 & 7.0 & 7.7 & 8.0 & 8.6 & 8.9 & 9.5 \\
\hline \multicolumn{8}{|l|}{ Chamaepinnularia mediocris (212005) } \\
\hline \multicolumn{8}{|l|}{ Chamaepinnularia soehrensis (212006) } \\
\hline \multicolumn{8}{|l|}{ Cocconeis placentula (16004) } \\
\hline Craticula halophila (21005) & & & & 1 & & & \\
\hline \multicolumn{8}{|l|}{ Craticula riparia (21016) } \\
\hline Cyclotella comensis (20023) & & 1 & & & & 2 & \\
\hline \multicolumn{8}{|l|}{ Cyclotella krammeri (20083) } \\
\hline Cyclotella ocellata (20009) & 28 & 33 & 37 & 33 & 16 & 41 & 30 \\
\hline Cyclotella rossii (20019) & 4 & & & 2 & & 2 & \\
\hline Cyclotella tripartita (20085) & 14 & 7 & 8 & 5 & 6 & 12 & 3 \\
\hline \multicolumn{8}{|l|}{ Cymbella affinis (23073) } \\
\hline \multicolumn{8}{|l|}{ Cymbella amphicephala (23001) } \\
\hline \multicolumn{8}{|l|}{ Cymbella cesatii (23004) } \\
\hline \multicolumn{8}{|l|}{ Cymbella cistula (23005) } \\
\hline \multicolumn{8}{|l|}{ Cymbella helvetica (23099) } \\
\hline \multicolumn{8}{|l|}{ Cymbella heteropleura (23100) } \\
\hline \multicolumn{8}{|l|}{ Cymbella lapponica (23116) } \\
\hline \multicolumn{8}{|l|}{ Cymbella rupicola (23020) } \\
\hline \multicolumn{8}{|l|}{ Cymbella schimanskii } \\
\hline Cymbella sileiaca & & 1 & 4 & 4 & 4 & 1 & 1 \\
\hline \multicolumn{8}{|l|}{ Cymbella tumidula (23082) } \\
\hline \multicolumn{8}{|l|}{ Cymbella tynnii (47141) } \\
\hline \multicolumn{8}{|l|}{ Cymbopleura angustata (190013) } \\
\hline \multicolumn{8}{|l|}{ Cymbopleura cuspidata (190001) } \\
\hline \multicolumn{8}{|l|}{ Cymbopleura subaequalis (190017) } \\
\hline \multicolumn{8}{|l|}{ Denticula elegans (25001) } \\
\hline Denticula keutzingii & & & 1 & & 2 & & \\
\hline \multicolumn{8}{|l|}{ Diatoma mesodon (27002) } \\
\hline \multicolumn{8}{|l|}{ Diatoma vulgaris (27013) } \\
\hline \multicolumn{8}{|l|}{ Diploneis boldtiana (30012) } \\
\hline \multicolumn{8}{|l|}{ Diploneis elliptica (30001) } \\
\hline Diploneis finnica (30002) & & & & & & & \\
\hline Diploneis marginestriata (30003) & & & & & & & 2 \\
\hline Diploneis ovalis (30009) & & & & & & & \\
\hline Diploneis parma (30014) & & 2 & & & & & \\
\hline Discostella pseudostelligera (2506002) & 7 & 19 & 11 & 14 & 15 & 12 & 7 \\
\hline Discostella stelligera (2506003) & 5 & & 1 & 3 & 2 & 1 & 9 \\
\hline
\end{tabular}




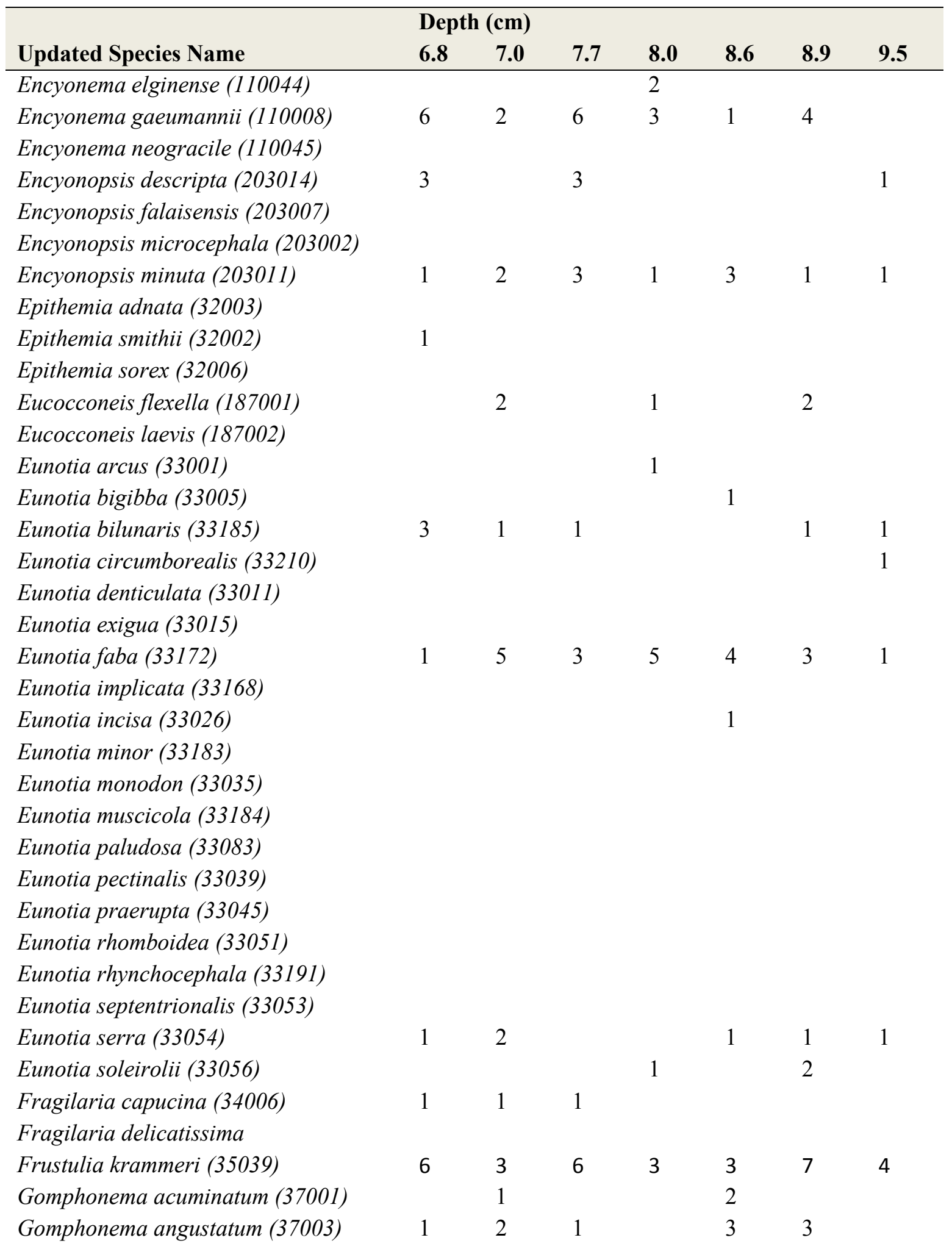




\begin{tabular}{|c|c|c|c|c|c|c|c|}
\hline \multirow[b]{2}{*}{ Updated Species Name } & \multicolumn{7}{|c|}{ Depth (cm) } \\
\hline & 6.8 & 7.0 & 7.7 & 8.0 & 8.6 & 8.9 & 9.5 \\
\hline \multicolumn{8}{|l|}{ Gomphonema olivaceum (37065) } \\
\hline \multicolumn{8}{|l|}{ Gomphonema parvulum (37010) } \\
\hline \multicolumn{8}{|l|}{ Gomphonema pseudosphaerophorum } \\
\hline \multicolumn{8}{|l|}{ Gomphonema rhombicum (37080) } \\
\hline \multicolumn{8}{|l|}{ Gomphonema sarcophagus (37152) } \\
\hline \multicolumn{8}{|l|}{ Gomphonema truncatum (37022) } \\
\hline Karayevia laterostrata (125002) & & & & & & 1 & \\
\hline \multicolumn{8}{|l|}{ Karayevia ploenensis (125008) } \\
\hline Karayevia suchlandtii (125009) & 4 & 4 & 4 & 1 & 1 & 10 & \\
\hline \multicolumn{8}{|l|}{ Navicula absoluta (46494) } \\
\hline Navicula cryptocephala (46014) & 4 & 1 & 1 & 2 & 2 & & 1 \\
\hline \multicolumn{8}{|l|}{ Navicula difficillima (46017) } \\
\hline \multicolumn{8}{|l|}{ Navicula levanderii } \\
\hline \multicolumn{8}{|l|}{ Navicula prominula } \\
\hline \multicolumn{8}{|l|}{ Navicula pseudobryophila (46807) } \\
\hline \multicolumn{8}{|l|}{ Navicula pseudoventralis (46166) } \\
\hline Navicula schmassmannii (46066) & & 1 & & & 2 & & 1 \\
\hline \multicolumn{8}{|l|}{ Navicula striolata (93266) } \\
\hline \multicolumn{8}{|l|}{ Navicula subrotundata (46079) } \\
\hline \multicolumn{8}{|l|}{ Navicula trivalis } \\
\hline \multicolumn{8}{|l|}{ Navicula viridula (46408) } \\
\hline \multicolumn{8}{|l|}{ Neidium affine (47001) } \\
\hline \multicolumn{8}{|l|}{ Neidium ampliatum (47066) } \\
\hline \multicolumn{8}{|l|}{ Neidium dubium (47011) } \\
\hline \multicolumn{8}{|l|}{ Neidium hitchcockii (47028) } \\
\hline Neidium iridis (47014) & & & & & & 1 & \\
\hline \multicolumn{8}{|l|}{ Neidium septentrionalis (47110) } \\
\hline \multicolumn{8}{|l|}{ Nitzschia angustata (48093) } \\
\hline \multicolumn{8}{|l|}{ Nitzschia behrei (48585) } \\
\hline Nitzschia diversa (48411) & & & & & & & \\
\hline Nitzschia elegans (48010) & & & & & & & \\
\hline Nitzschia fonticola (48011) & 7 & 5 & 11 & 13 & 4 & 10 & 10 \\
\hline Nitzschia gisela (48624) & & & & & & & \\
\hline Nitzschia graciliformis (48119) & & & & & & & \\
\hline Nitzschia gracilis (48015) & & & & & & & \\
\hline Nitzschia recta (48029) & & & & & & & \\
\hline Nitzschia tropica (48045) & & & & & & & \\
\hline
\end{tabular}




\begin{tabular}{|c|c|c|c|c|c|c|c|}
\hline \multirow[b]{2}{*}{ Updated Species Name } & \multicolumn{7}{|c|}{ Depth (cm) } \\
\hline & 6.8 & 7.0 & 7.7 & 8.0 & 8.6 & 8.9 & 9.5 \\
\hline \multicolumn{8}{|l|}{ Nupela gracillima (92026) } \\
\hline \multicolumn{8}{|l|}{ Oxyneis binalis (9107001) } \\
\hline \multicolumn{8}{|l|}{ Pinnularia alpina (52807) } \\
\hline \multicolumn{8}{|l|}{ Pinnularia appendiculata (52009) } \\
\hline \multicolumn{8}{|l|}{ Pinnularia borealis (52013) } \\
\hline \multicolumn{8}{|l|}{ Pinnularia brauniana (103001) } \\
\hline \multicolumn{8}{|l|}{ Pinnularia divergens (52025) } \\
\hline \multicolumn{8}{|l|}{ Pinnularia episcopalis } \\
\hline \multicolumn{8}{|l|}{ Pinnularia gibba (52159) } \\
\hline Pinnularia interrupta (52194) & & 2 & & & & & \\
\hline \multicolumn{8}{|l|}{ Pinnularia karelica } \\
\hline \multicolumn{8}{|l|}{ Pinnularia microstauron (52045) } \\
\hline \multicolumn{8}{|l|}{ Pinnularia nobilis (103038) } \\
\hline Pinnularia nodosa (52048) & & & & & & & 6 \\
\hline \multicolumn{8}{|l|}{ Pinnularia polyonca (52087) } \\
\hline \multicolumn{8}{|l|}{ Pinnularia polyonca (52087) } \\
\hline Pinnularia pulchra (52801) & & & & 1 & & & \\
\hline Pinnularia subcapitata (52059) & & 2 & 1 & & 3 & 2 & \\
\hline \multicolumn{8}{|l|}{ Pinnularia subrostrata (52184) } \\
\hline \multicolumn{8}{|l|}{ Pinnularia superdiverdentissima } \\
\hline Pinnularia viridis (52071) & & & & & & 1 & 2 \\
\hline \multicolumn{8}{|l|}{ Placoneis elginensis (194005) } \\
\hline \multicolumn{8}{|l|}{ Planothidium joursacense (155016) } \\
\hline \multicolumn{8}{|l|}{ Planothidium oestrupii (155026) } \\
\hline \multicolumn{8}{|l|}{ Platessa holsatica (2508002) } \\
\hline Psammothidium curtissimum (186021) & 1 & & & & 1 & 2 & 3 \\
\hline \multicolumn{8}{|l|}{ Psammothidium didymum (186012) } \\
\hline \multicolumn{8}{|l|}{ Psammothidium helveticum (186003) } \\
\hline Psammothidium ventralis (186009) & 2 & & & & & & \\
\hline Pseudostaurosira brevistriata (73001) & 29 & 20 & 34 & 25 & 13 & 26 & 10 \\
\hline Pseudostaurosira elliptica (73025) & 2 & 5 & 4 & 6 & 5 & 3 & \\
\hline Pseudostaurosira pseudoconstruens (73002) & 3 & 4 & 1 & & 5 & 1 & \\
\hline Puncticulata bodanica (208004) & 4 & 2 & 6 & 2 & 3 & 1 & 3 \\
\hline \multicolumn{8}{|l|}{ Reimeria sinuata (55002) } \\
\hline Rossithidium nodosum (189006) & 5 & & & & & & \\
\hline Rossithidium pusillum (189003) & 9 & 1 & 4 & 5 & 2 & 3 & 5 \\
\hline Sellaphora pupula (170006) & 4 & 2 & 2 & 2 & 3 & 5 & 1 \\
\hline
\end{tabular}




\begin{tabular}{|c|c|c|c|c|c|c|c|}
\hline \multirow[b]{2}{*}{ Updated Species Name } & \multicolumn{7}{|c|}{ Depth (cm) } \\
\hline & 6.8 & 7.0 & 7.7 & 8.0 & 8.6 & 8.9 & 9.5 \\
\hline \multicolumn{8}{|l|}{ Stauroneis acuta (62036) } \\
\hline \multicolumn{8}{|l|}{ Stauroneis anceps (62002) } \\
\hline \multicolumn{8}{|l|}{ Stauroneis cf. javanica (62045) } \\
\hline Stauroneis cf. schimanskii (62127) & & & & 1 & & & \\
\hline Stauroneis phoenicenteron (62015) & & & & & & & 1 \\
\hline Stauroneis producta (62017) & 2 & 1 & 2 & & & 1 & \\
\hline Stauroneis prominula (62069) & & & 1 & 1 & & & \\
\hline \multicolumn{8}{|l|}{ Stauroneis thermicola (62040) } \\
\hline Staurosira construens (172001) & 2 & & & 1 & & & 1 \\
\hline Staurosira construens var. binodis (172005) & 11 & 8 & 7 & 8 & 7 & 8 & 12 \\
\hline Staurosira construens var. exigua (172022) & 28 & 34 & 33 & 29 & 22 & 40 & 35 \\
\hline Staurosira construens var. venter (172006) & 6 & 8 & 11 & 4 & 5 & 9 & 20 \\
\hline \multicolumn{8}{|l|}{ Staurosirella lapponica (175002) } \\
\hline Staurosirella leptostauron var. rhomboides (175017) & 6 & 3 & 6 & 3 & 3 & 7 & 4 \\
\hline Staurosirella pinnata (175005) & 9 & 2 & 3 & 5 & 5 & 4 & 3 \\
\hline \multicolumn{8}{|l|}{ Stenopterobia anceps (63003) } \\
\hline \multicolumn{8}{|l|}{ Stenopterobia delicatissima (63007) } \\
\hline \multicolumn{8}{|l|}{ Surirella amphioxys (65069) } \\
\hline \multicolumn{8}{|l|}{ Surirella angusta (65002) } \\
\hline \multicolumn{8}{|l|}{ Surirella elegans (65072) } \\
\hline \multicolumn{8}{|l|}{ Surirella gracilis (65013) } \\
\hline Surirella linearis (65014) & & 2 & 1 & & 2 & & \\
\hline Tabellaria fenestrata (67002) & 2 & 1 & & 1 & 1 & & \\
\hline Tabellaria flocculosa (67004) & 5 & 3 & 11 & 4 & 4 & 9 & 5 \\
\hline \multicolumn{8}{|l|}{ Tabularia fasciculata (200002) } \\
\hline Tetracyclus glans (71006) & & 1 & 3 & 2 & 1 & & \\
\hline \multicolumn{8}{|l|}{ Tetracyclus lacustris (71003) } \\
\hline "Total chrysophyte cysts per slice & 43 & 27 & 7 & 28 & 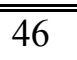 & 30 & 74 \\
\hline Total diatom counts per slice & 437 & 454 & 501 & 446 & 433 & 443 & 465 \\
\hline Total microspheres per slice & 160 & & 710 & & 31 & & 69 \\
\hline
\end{tabular}




\begin{tabular}{|c|c|c|c|c|c|c|c|}
\hline \multirow[b]{2}{*}{ Updated Species Name } & \multicolumn{2}{|c|}{ Depth (cm) } & \multirow[b]{2}{*}{10.7} & \multirow[b]{2}{*}{11.3} & \multirow[b]{2}{*}{11.6} & \multirow[b]{2}{*}{12.2} & \multirow[b]{2}{*}{12.4} \\
\hline & 9.8 & 10.4 & & & & & \\
\hline \multicolumn{8}{|l|}{ Achnanthes imperfecta (2051) } \\
\hline Achnanthes levanderi (2022) & 2 & 5 & 11 & 4 & 8 & 1 & 4 \\
\hline \multicolumn{8}{|l|}{ Achnanthes pergalli } \\
\hline Achnanthes pseudoswazi (2206) & & & & & & 1 & 1 \\
\hline \multicolumn{8}{|l|}{ Achnanthes trinodis (2109) } \\
\hline Achnanthidium minutissimum (1010) & 8 & 26 & 25 & 25 & 15 & 20 & 4 \\
\hline \multicolumn{8}{|l|}{ Achnanthidium semiapertum (1028) } \\
\hline \multicolumn{8}{|l|}{ Amphipleura lindheimerii } \\
\hline \multicolumn{8}{|l|}{ Amphora copulata (7075) } \\
\hline \multicolumn{8}{|l|}{ Amphora ovalis (7001) } \\
\hline Aulacoseira alpigena (10028) & 200 & 173 & 127 & 121 & 143 & 150 & 155 \\
\hline \multicolumn{8}{|l|}{ Aulacoseira ambigua (10008) } \\
\hline Aulacoseira canadensis (10003) & & & & & & 1 & \\
\hline \multicolumn{8}{|l|}{ Aulacoseira crassipunctata (10001) } \\
\hline Aulacoseira distans (10009) & 20 & 17 & 26 & 26 & 24 & 15 & 20 \\
\hline \multicolumn{8}{|l|}{ Aulacoseira granulata (10018) } \\
\hline \multicolumn{8}{|l|}{ Aulacoseira italica (10019) } \\
\hline Aulacoseira lacustris (10060) & 54 & 27 & 23 & 41 & 39 & 23 & 31 \\
\hline \multicolumn{8}{|l|}{ Aulacoseira lirata (10012) } \\
\hline \multicolumn{8}{|l|}{ Aulacoseira muzzanensis (10031) } \\
\hline Aulacoseira perglabra (10006) & 14 & 11 & 2 & 9 & 13 & 10 & 10 \\
\hline Aulacoseira subarctica (10015) & 1 & & 3 & 1 & 2 & 1 & 3 \\
\hline Aulacoseira tethera (10033) & & & & & 2 & & 1 \\
\hline \multicolumn{8}{|l|}{ Aulacoseira valida (10029) } \\
\hline \multicolumn{8}{|l|}{ Bacillaria paradoxa (76001) } \\
\hline Brachysira brebissonii (18005) & 8 & 17 & 11 & 6 & 13 & 4 & 10 \\
\hline Brachysira microcephala (18013) & & 3 & & 1 & 1 & 3 & \\
\hline \multicolumn{8}{|l|}{ Caloneis alpestris (12025) } \\
\hline \multicolumn{8}{|l|}{ Caloneis lauta (12026) } \\
\hline \multicolumn{8}{|l|}{ Caloneis permagna (12030) } \\
\hline Caloneis silicula (12010) & & & & 1 & & & \\
\hline \multicolumn{8}{|l|}{ Caloneis tenuis (12013) } \\
\hline Caloneis thermalis (12054) & & & & & & & \\
\hline Caloneis undulata (12022) & & & & & & & \\
\hline Caloneis westii (12056) & & & & & & & \\
\hline Cavinula cocconeiformis (195001) & & 3 & & 2 & 5 & 4 & 1 \\
\hline Cavinula pseudoscutiformis (195003) & 4 & 3 & 4 & 5 & 2 & 3 & 3 \\
\hline
\end{tabular}




\begin{tabular}{|c|c|c|c|c|c|c|c|}
\hline \multirow[b]{2}{*}{ Updated Species Name } & \multicolumn{7}{|c|}{ Depth (cm) } \\
\hline & 9.8 & 10.4 & 10.7 & 11.3 & 11.6 & 12.2 & 12.4 \\
\hline Chamaepinnularia mediocris (212005) & & & & & 1 & 1 & \\
\hline \multicolumn{8}{|l|}{ Chamaepinnularia soehrensis (212006) } \\
\hline \multicolumn{8}{|l|}{ Cocconeis placentula (16004) } \\
\hline \multicolumn{8}{|l|}{ Craticula halophila (21005) } \\
\hline \multicolumn{8}{|l|}{ Craticula riparia (21016) } \\
\hline Cyclotella comensis (20023) & & & & 1 & & 1 & \\
\hline \multicolumn{8}{|l|}{ Cyclotella krammeri (20083) } \\
\hline Cyclotella ocellata (20009) & 12 & 23 & 38 & 29 & 28 & 28 & 40 \\
\hline Cyclotella rossii (20019) & 3 & & 4 & & & & 3 \\
\hline Cyclotella tripartita (20085) & 5 & 7 & 18 & 6 & 4 & 4 & 7 \\
\hline \multicolumn{8}{|l|}{ Cymbella affinis (23073) } \\
\hline \multicolumn{8}{|l|}{ Cymbella amphicephala (23001) } \\
\hline \multicolumn{8}{|l|}{ Cymbella cesatii (23004) } \\
\hline \multicolumn{8}{|l|}{ Cymbella cistula (23005) } \\
\hline \multicolumn{8}{|l|}{ Cymbella helvetica (23099) } \\
\hline \multicolumn{8}{|l|}{ Cymbella heteropleura (23100) } \\
\hline \multicolumn{8}{|l|}{ Cymbella lapponica (23116) } \\
\hline \multicolumn{8}{|l|}{ Cymbella rupicola (23020) } \\
\hline \multicolumn{8}{|l|}{ Cymbella schimanskii } \\
\hline Cymbella sileiaca & 4 & 3 & 6 & 2 & 4 & 7 & \\
\hline \multicolumn{8}{|l|}{ Cymbella tumidula (23082) } \\
\hline \multicolumn{8}{|l|}{ Cymbella tynnii (47141) } \\
\hline \multicolumn{8}{|l|}{ Cymbopleura angustata (190013) } \\
\hline Cymbopleura cuspidata (190001) & 1 & & & & & & \\
\hline \multicolumn{8}{|l|}{ Cymbopleura subaequalis (190017) } \\
\hline \multicolumn{8}{|l|}{ Denticula elegans (25001) } \\
\hline Denticula keutzingii & & & & & & 1 & \\
\hline \multicolumn{8}{|l|}{ Diatoma mesodon (27002) } \\
\hline \multicolumn{8}{|l|}{ Diatoma vulgaris (27013) } \\
\hline \multicolumn{8}{|l|}{ Diploneis boldtiana (30012) } \\
\hline \multicolumn{8}{|l|}{ Diploneis elliptica (30001) } \\
\hline \multicolumn{8}{|l|}{ Diploneis finnica (30002) } \\
\hline Diploneis marginestriata (30003) & & 1 & 2 & & 1 & 1 & \\
\hline Diploneis ovalis (30009) & & & & & & & \\
\hline Diploneis parma (30014) & 1 & & & & 2 & & 2 \\
\hline Discostella pseudostelligera (2506002) & 3 & 6 & 13 & 10 & 16 & 14 & 8 \\
\hline Discostella stelligera (2506003) & 3 & 8 & 6 & 4 & 1 & 1 & 6 \\
\hline
\end{tabular}




\begin{tabular}{|c|c|c|c|c|c|c|c|}
\hline \multirow[b]{2}{*}{ Updated Species Name } & \multicolumn{2}{|c|}{ Depth (cm) } & \multirow[b]{2}{*}{10.7} & \multirow[b]{2}{*}{11.3} & \multirow[b]{2}{*}{11.6} & \multirow[b]{2}{*}{12.2} & \multirow[b]{2}{*}{12.4} \\
\hline & 9.8 & 10.4 & & & & & \\
\hline \multicolumn{8}{|l|}{ Encyonema elginense (110044) } \\
\hline Encyonema gaeumannii (110008) & 3 & 3 & 2 & 3 & 7 & 1 & 2 \\
\hline \multicolumn{8}{|l|}{ Encyonema neogracile (110045) } \\
\hline Encyonopsis descripta (203014) & 1 & 1 & 1 & 1 & & & 1 \\
\hline \multicolumn{8}{|l|}{ Encyonopsis falaisensis (203007) } \\
\hline \multicolumn{8}{|l|}{ Encyonopsis microcephala (203002) } \\
\hline Encyonopsis minuta (203011) & 2 & 2 & 1 & 1 & 1 & & 2 \\
\hline \multicolumn{8}{|l|}{ Epithemia adnata (32003) } \\
\hline Epithemia smithii (32002) & & & & 1 & 1 & & \\
\hline \multicolumn{8}{|l|}{ Epithemia sorex (32006) } \\
\hline Eucocconeis flexella (187001) & 1 & 1 & 1 & & & 2 & \\
\hline \multicolumn{8}{|l|}{ Eucocconeis laevis (187002) } \\
\hline Eunotia arcus (33001) & & 1 & 1 & & 2 & 1 & \\
\hline \multicolumn{8}{|l|}{ Eunotia bigibba (33005) } \\
\hline Eunotia bilunaris (33185) & 2 & & & 1 & 2 & & 2 \\
\hline \multicolumn{8}{|l|}{ Eunotia circumborealis (33210) } \\
\hline Eunotia denticulata (33011) & & & & 1 & & & \\
\hline \multicolumn{8}{|l|}{ Eunotia exigua (33015) } \\
\hline Eunotia faba (33172) & 5 & 4 & 7 & 6 & 5 & 2 & 6 \\
\hline \multicolumn{8}{|l|}{ Eunotia implicata (33168) } \\
\hline Eunotia incisa (33026) & & & & & & & 1 \\
\hline \multicolumn{8}{|l|}{ Eunotia minor (33183) } \\
\hline \multicolumn{8}{|l|}{ Eunotia monodon (33035) } \\
\hline Eunotia muscicola (33184) & & & 1 & & & & \\
\hline \multicolumn{8}{|l|}{ Eunotia paludosa (33083) } \\
\hline \multicolumn{8}{|l|}{ Eunotia pectinalis (33039) } \\
\hline \multicolumn{8}{|l|}{ Eunotia praerupta (33045) } \\
\hline \multicolumn{8}{|l|}{ Eunotia rhomboidea (33051) } \\
\hline \multicolumn{8}{|l|}{ Eunotia rhynchocephala (33191) } \\
\hline \multicolumn{8}{|l|}{ Eunotia septentrionalis (33053) } \\
\hline Eunotia serra (33054) & 2 & & & & 1 & 1 & \\
\hline Eunotia soleirolii (33056) & & & & & & & 1 \\
\hline Fragilaria capucina (34006) & 1 & & & & & & \\
\hline Fragilaria delicatissima & & & & & & & \\
\hline Frustulia krammeri (35039) & 2 & 3 & 3 & 4 & 5 & 3 & 2 \\
\hline Gomphonema acuminatum (37001) & & & & & & & \\
\hline Gomphonema angustatum (37003) & & & & & 1 & 4 & \\
\hline
\end{tabular}




\begin{tabular}{|c|c|c|c|c|c|c|c|}
\hline \multirow[b]{2}{*}{ Updated Species Name } & \multicolumn{7}{|c|}{ Depth (cm) } \\
\hline & 9.8 & 10.4 & 10.7 & 11.3 & 11.6 & 12.2 & 12.4 \\
\hline \multicolumn{8}{|l|}{ Gomphonema olivaceum (37065) } \\
\hline \multicolumn{8}{|l|}{ Gomphonema parvulum (37010) } \\
\hline \multicolumn{8}{|l|}{ Gomphonema pseudosphaerophorum } \\
\hline \multicolumn{8}{|l|}{ Gomphonema rhombicum (37080) } \\
\hline Gomphonema sarcophagus (37152) & & & & 1 & & & \\
\hline \multicolumn{8}{|l|}{ Gomphonema truncatum (37022) } \\
\hline \multicolumn{8}{|l|}{ Karayevia laterostrata (125002) } \\
\hline \multicolumn{8}{|l|}{ Karayevia ploenensis (125008) } \\
\hline Karayevia suchlandtii (125009) & & 4 & 6 & 6 & 2 & 0 & 4 \\
\hline \multicolumn{8}{|l|}{ Navicula absoluta (46494) } \\
\hline Navicula cryptocephala (46014) & 1 & 2 & 1 & & & & 1 \\
\hline \multicolumn{8}{|l|}{ Navicula difficillima (46017) } \\
\hline \multicolumn{8}{|l|}{ Navicula levanderii } \\
\hline \multicolumn{8}{|l|}{ Navicula prominula } \\
\hline \multicolumn{8}{|l|}{ Navicula pseudobryophila (46807) } \\
\hline \multicolumn{8}{|l|}{ Navicula pseudoventralis (46166) } \\
\hline Navicula schmassmannii (46066) & & & 1 & 2 & & & \\
\hline \multicolumn{8}{|l|}{ Navicula striolata (93266) } \\
\hline \multicolumn{8}{|l|}{ Navicula subrotundata (46079) } \\
\hline \multicolumn{8}{|l|}{ Navicula trivalis } \\
\hline \multicolumn{8}{|l|}{ Navicula viridula (46408) } \\
\hline \multicolumn{8}{|l|}{ Neidium affine (47001) } \\
\hline Neidium ampliatum (47066) & & & & & 1 & & 1 \\
\hline \multicolumn{8}{|l|}{ Neidium dubium (47011) } \\
\hline \multicolumn{8}{|l|}{ Neidium hitchcockii (47028) } \\
\hline \multicolumn{8}{|l|}{ Neidium iridis (47014) } \\
\hline Neidium septentrionalis (47110) & & & & & 1 & & \\
\hline \multicolumn{8}{|l|}{ Nitzschia angustata (48093) } \\
\hline \multicolumn{8}{|l|}{ Nitzschia behrei (48585) } \\
\hline \multicolumn{8}{|l|}{ Nitzschia diversa (48411) } \\
\hline Nitzschia elegans (48010) & 1 & & & & & & 3 \\
\hline Nitzschia fonticola (48011) & & 6 & 7 & 7 & 9 & 7 & 5 \\
\hline Nitzschia gisela (48624) & & & & & & & \\
\hline Nitzschia graciliformis (48119) & & & & & & & \\
\hline Nitzschia gracilis (48015) & & & & & & & \\
\hline Nitzschia recta (48029) & & & & & & & \\
\hline Nitzschia tropica (48045) & & & & & & & \\
\hline
\end{tabular}




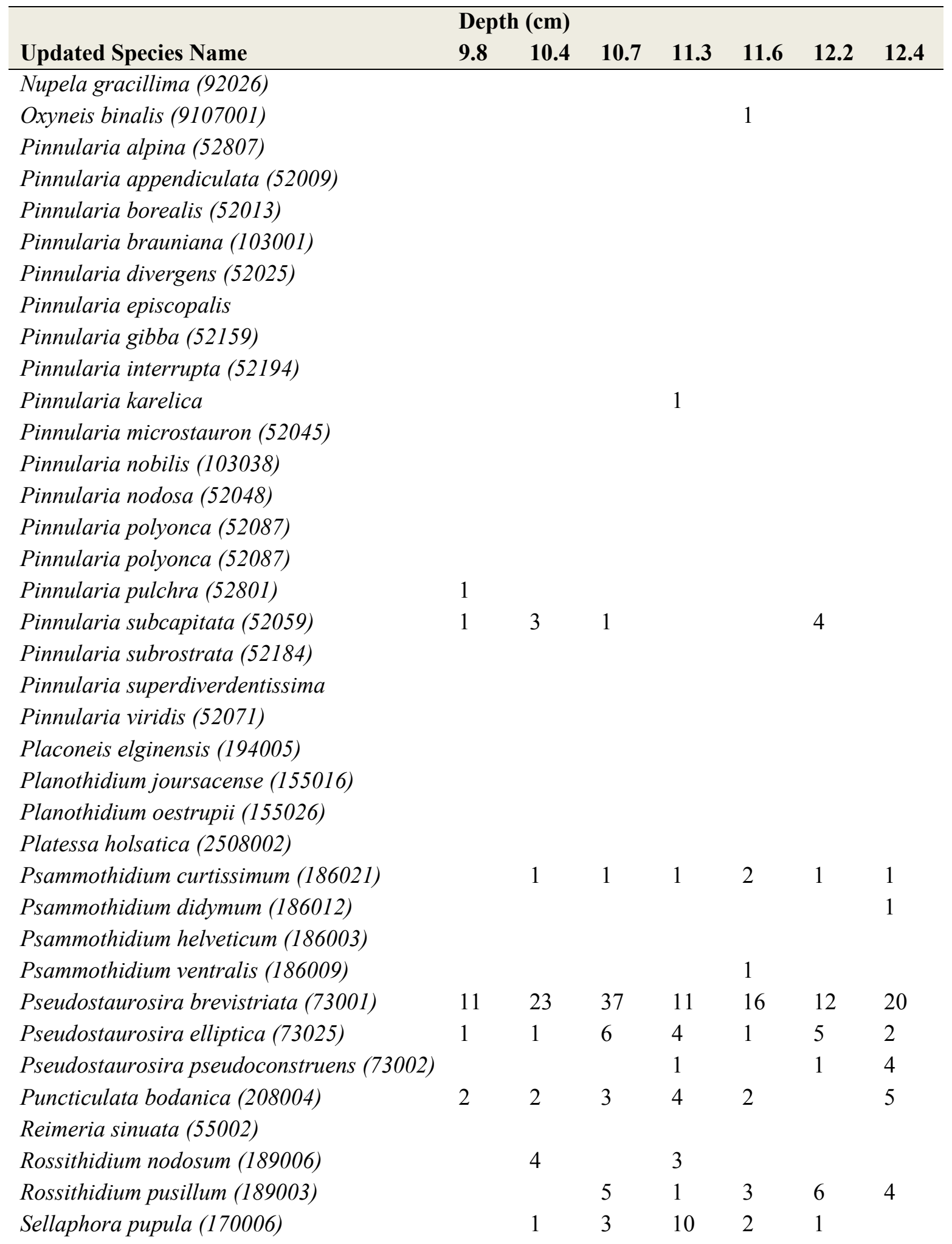




\section{Depth (cm)}

Updated Species Name

$\begin{array}{lllllll}9.8 & 10.4 & 10.7 & 11.3 & 11.6 & 12.2 & 12.4\end{array}$

Stauroneis acuta (62036)

Stauroneis anceps (62002)

Stauroneis cf. javanica (62045)

Stauroneis cf. schimanskii (62127)

Stauroneis phoenicenteron (62015)

Stauroneis producta (62017)

Stauroneis prominula (62069)

Stauroneis thermicola (62040)

Staurosira construens (172001)

Staurosira construens var. binodis (172005)

Staurosira construens var. exigua (172022)

$\begin{array}{lllllll}3 & 9 & 15 & 3 & 8 & 8 & 5\end{array}$

Staurosira construens var. venter (172006)

$\begin{array}{lllllll}23 & 28 & 42 & 35 & 23 & 30 & 22\end{array}$

Staurosirella lapponica (175002)

$\begin{array}{llllllll}\text { Staurosirella leptostauron var. rhomboides (175017) } & 2 & 3 & 3 & 4 & 5 & 3 & 2 \\ \text { Staurosirella pinnata (175005) } & 1 & 4 & 6 & 4 & & 2 & 6\end{array}$

Stenopterobia anceps (63003)

Stenopterobia delicatissima (63007)

Surirella amphioxys (65069)

Surirella angusta (65002)

Surirella elegans (65072)

Surirella gracilis (65013)

Surirella linearis (65014)

Tabellaria fenestrata (67002)

Tabellaria flocculosa (67004)

Tabularia fasciculata (200002)

$\begin{array}{lllllll}6 & 12 & 10 & 14 & 9 & 12 & 13\end{array}$

Tetracyclus glans (71006)

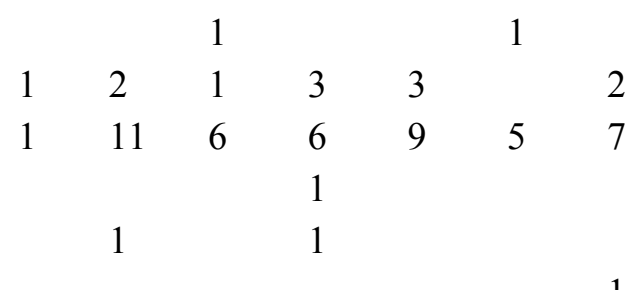

Tetracyclus lacustris (71003)

\begin{tabular}{llllllll}
\hline \hline Total chrysophyte cysts per slice & 43 & 50 & 24 & 66 & 35 & 53 & 114 \\
Total diatom counts per slice & 418 & 467 & 494 & 439 & 448 & 408 & 437 \\
Total microspheres per slice & & 67 & & 86 & & 90 &
\end{tabular}




\begin{tabular}{|c|c|c|c|c|c|c|c|}
\hline \multirow[b]{2}{*}{ Updated Species Name } & \multicolumn{7}{|c|}{ Depth (cm) } \\
\hline & 13.0 & 13.3 & 13.9 & 14.2 & 14.8 & 15.1 & 15.7 \\
\hline \multicolumn{8}{|l|}{ Achnanthes imperfecta (2051) } \\
\hline Achnanthes levanderi (2022) & 7 & 3 & 11 & 8 & 12 & 2 & 8 \\
\hline \multicolumn{8}{|l|}{ Achnanthes pergalli } \\
\hline \multicolumn{8}{|l|}{ Achnanthes pseudoswazi (2206) } \\
\hline \multicolumn{8}{|l|}{ Achnanthes trinodis (2109) } \\
\hline Achnanthidium minutissimum (1010) & 20 & 18 & 30 & 23 & 20 & 20 & 19 \\
\hline \multicolumn{8}{|l|}{ Achnanthidium semiapertum (1028) } \\
\hline \multicolumn{8}{|l|}{ Amphipleura lindheimerii } \\
\hline \multicolumn{8}{|l|}{ Amphora copulata (7075) } \\
\hline Amphora ovalis (7001) & & 2 & & & 1 & & \\
\hline Aulacoseira alpigena (10028) & 126 & 137 & 120 & 153 & 171 & 145 & 152 \\
\hline \multicolumn{8}{|l|}{ Aulacoseira ambigua (10008) } \\
\hline Aulacoseira canadensis (10003) & & 1 & & & & & \\
\hline \multicolumn{8}{|l|}{ Aulacoseira crassipunctata (10001) } \\
\hline Aulacoseira distans (10009) & 22 & 25 & 24 & 25 & 21 & 21 & 34 \\
\hline \multicolumn{8}{|l|}{ Aulacoseira granulata (10018) } \\
\hline \multicolumn{8}{|l|}{ Aulacoseira italica (10019) } \\
\hline Aulacoseira lacustris (10060) & 42 & 45 & 35 & 26 & 31 & 32 & 19 \\
\hline \multicolumn{8}{|l|}{ Aulacoseira lirata (10012) } \\
\hline \multicolumn{8}{|l|}{ Aulacoseira muzzanensis (10031) } \\
\hline Aulacoseira perglabra (10006) & 12 & 8 & 14 & 9 & 12 & 11 & 15 \\
\hline Aulacoseira subarctica (10015) & 1 & 3 & 2 & & 2 & & 1 \\
\hline Aulacoseira tethera (10033) & 3 & & & & 2 & 1 & \\
\hline \multicolumn{8}{|l|}{ Aulacoseira valida (10029) } \\
\hline \multicolumn{8}{|l|}{ Bacillaria paradoxa (76001) } \\
\hline Brachysira brebissonii (18005) & & 12 & 6 & 10 & 7 & 8 & 10 \\
\hline Brachysira microcephala (18013) & 2 & 1 & 1 & 2 & 4 & 2 & 2 \\
\hline \multicolumn{8}{|l|}{ Caloneis alpestris (12025) } \\
\hline \multicolumn{8}{|l|}{ Caloneis lauta (12026) } \\
\hline \multicolumn{8}{|l|}{ Caloneis permagna (12030) } \\
\hline \multicolumn{8}{|l|}{ Caloneis silicula (12010) } \\
\hline \multicolumn{8}{|l|}{ Caloneis tenuis (12013) } \\
\hline \multicolumn{8}{|l|}{ Caloneis thermalis (12054) } \\
\hline \multicolumn{8}{|l|}{ Caloneis undulata (12022) } \\
\hline \multicolumn{8}{|l|}{ Caloneis westii (12056) } \\
\hline Cavinula cocconeiformis (195001) & 3 & 2 & 2 & & 1 & 2 & 3 \\
\hline Cavinula pseudoscutiformis (195003) & 5 & 6 & 6 & 4 & 6 & 1 & 3 \\
\hline
\end{tabular}




\begin{tabular}{|c|c|c|c|c|c|c|c|}
\hline \multirow[b]{2}{*}{ Updated Species Name } & \multicolumn{7}{|c|}{ Depth (cm) } \\
\hline & 13.0 & 13.3 & 13.9 & 14.2 & 14.8 & 15.1 & 15.7 \\
\hline Chamaepinnularia mediocris (212005) & & & & 1 & 2 & & \\
\hline Chamaepinnularia soehrensis (212006) & & & 4 & & & & \\
\hline \multicolumn{8}{|l|}{ Cocconeis placentula (16004) } \\
\hline Craticula halophila (21005) & & & & 1 & 2 & & \\
\hline \multicolumn{8}{|l|}{ Craticula riparia (21016) } \\
\hline Cyclotella comensis (20023) & & 1 & & 1 & 1 & 1 & 1 \\
\hline \multicolumn{8}{|l|}{ Cyclotella krammeri (20083) } \\
\hline Cyclotella ocellata (20009) & 23 & 39 & 24 & 30 & 29 & 31 & 29 \\
\hline Cyclotella rossii (20019) & & 2 & & & & & \\
\hline Cyclotella tripartita (20085) & 4 & 5 & 7 & 4 & 4 & 2 & 5 \\
\hline \multicolumn{8}{|l|}{ Cymbella affinis (23073) } \\
\hline \multicolumn{8}{|l|}{ Cymbella amphicephala (23001) } \\
\hline \multicolumn{8}{|l|}{ Cymbella cesatii (23004) } \\
\hline \multicolumn{8}{|l|}{ Cymbella cistula (23005) } \\
\hline \multicolumn{8}{|l|}{ Cymbella helvetica (23099) } \\
\hline \multicolumn{8}{|l|}{ Cymbella heteropleura (23100) } \\
\hline \multicolumn{8}{|l|}{ Cymbella lapponica (23116) } \\
\hline \multicolumn{8}{|l|}{ Cymbella rupicola (23020) } \\
\hline \multicolumn{8}{|l|}{ Cymbella schimanskii } \\
\hline Cymbella sileiaca & 2 & 2 & 5 & & 4 & 1 & 2 \\
\hline \multicolumn{8}{|l|}{ Cymbella tumidula (23082) } \\
\hline \multicolumn{8}{|l|}{ Cymbella tynnii (47141) } \\
\hline Cymbopleura angustata (190013) & & 1 & & & & & \\
\hline Cymbopleura cuspidata (190001) & & & & & & & 2 \\
\hline \multicolumn{8}{|l|}{ Cymbopleura subaequalis (190017) } \\
\hline \multicolumn{8}{|l|}{ Denticula elegans (25001) } \\
\hline Denticula keutzingii & & & 1 & & & & 1 \\
\hline \multicolumn{8}{|l|}{ Diatoma mesodon (27002) } \\
\hline \multicolumn{8}{|l|}{ Diatoma vulgaris (27013) } \\
\hline \multicolumn{8}{|l|}{ Diploneis boldtiana (30012) } \\
\hline \multicolumn{8}{|l|}{ Diploneis elliptica (30001) } \\
\hline \multicolumn{8}{|l|}{ Diploneis finnica (30002) } \\
\hline Diploneis marginestriata (30003) & 1 & & & & 3 & & 1 \\
\hline Diploneis ovalis (30009) & & & & & & 1 & \\
\hline Diploneis parma (30014) & 1 & & & & & 1 & \\
\hline Discostella pseudostelligera (2506002) & 23 & 17 & 12 & 14 & 17 & 17 & 19 \\
\hline Discostella stelligera (2506003) & 1 & & 3 & 1 & 1 & & 4 \\
\hline
\end{tabular}




\begin{tabular}{|c|c|c|c|c|c|c|c|}
\hline \multirow[b]{2}{*}{ Updated Species Name } & \multicolumn{7}{|c|}{ Depth (cm) } \\
\hline & 13.0 & 13.3 & 13.9 & 14.2 & 14.8 & 15.1 & 15.7 \\
\hline \multicolumn{8}{|l|}{ Encyonema elginense (110044) } \\
\hline Encyonema gaeumannii (110008) & 5 & 3 & 3 & 3 & 4 & 3 & 8 \\
\hline \multicolumn{8}{|l|}{ Encyonema neogracile (110045) } \\
\hline Encyonopsis descripta (203014) & 1 & & & 1 & & & \\
\hline \multicolumn{8}{|l|}{ Encyonopsis falaisensis (203007) } \\
\hline \multicolumn{8}{|l|}{ Encyonopsis microcephala (203002) } \\
\hline Encyonopsis minuta (203011) & 1 & 2 & 1 & 1 & 1 & 1 & \\
\hline \multicolumn{8}{|l|}{ Epithemia adnata (32003) } \\
\hline \multicolumn{8}{|l|}{ Epithemia smithii (32002) } \\
\hline \multicolumn{8}{|l|}{ Epithemia sorex (32006) } \\
\hline Eucocconeis flexella (187001) & & & & 1 & & & \\
\hline \multicolumn{8}{|l|}{ Eucocconeis laevis (187002) } \\
\hline Eunotia arcus (33001) & 2 & & & & & 1 & 2 \\
\hline Eunotia bigibba (33005) & & & & 2 & & & \\
\hline Eunotia bilunaris (33185) & & 1 & 1 & 1 & & 1 & 2 \\
\hline \multicolumn{8}{|l|}{ Eunotia circumborealis (33210) } \\
\hline Eunotia denticulata (33011) & & 1 & & & & & \\
\hline \multicolumn{8}{|l|}{ Eunotia exigua (33015) } \\
\hline Eunotia faba (33172) & 5 & 7 & 3 & 5 & 1 & & 2 \\
\hline Eunotia implicata (33168) & & & 2 & & & & \\
\hline Eunotia incisa (33026) & & 2 & & 1 & & & \\
\hline \multicolumn{8}{|l|}{ Eunotia minor (33183) } \\
\hline \multicolumn{8}{|l|}{ Eunotia monodon (33035) } \\
\hline \multicolumn{8}{|l|}{ Eunotia muscicola (33184) } \\
\hline \multicolumn{8}{|l|}{ Eunotia paludosa (33083) } \\
\hline \multicolumn{8}{|l|}{ Eunotia pectinalis (33039) } \\
\hline \multicolumn{8}{|l|}{ Eunotia praerupta (33045) } \\
\hline \multicolumn{8}{|l|}{ Eunotia rhomboidea (33051) } \\
\hline \multicolumn{8}{|l|}{ Eunotia rhynchocephala (33191) } \\
\hline \multicolumn{8}{|l|}{ Eunotia septentrionalis (33053) } \\
\hline Eunotia serra (33054) & 2 & 1 & & 1 & & & 1 \\
\hline Eunotia soleirolii (33056) & & & & & & 1 & \\
\hline Fragilaria capucina (34006) & & & 1 & & 2 & 1 & \\
\hline \multicolumn{8}{|l|}{ Fragilaria delicatissima } \\
\hline Frustulia krammeri (35039) & 2 & 3 & 9 & 4 & 1 & 2 & 4 \\
\hline Gomphonema acuminatum (37001) & 3 & 1 & & & 1 & & 1 \\
\hline Gomphonema angustatum (37003) & & 1 & 1 & 2 & 1 & 1 & \\
\hline
\end{tabular}




\begin{tabular}{|c|c|c|c|c|c|c|c|}
\hline & Dept & (cm) & & & & & \\
\hline Updated Species Name & 13.0 & 13.3 & 13.9 & 14.2 & 14.8 & 15.1 & 15.7 \\
\hline Gomphonema olivaceum (37065) & & & & & & & \\
\hline Gomphonema parvulum (37010) & & & & & & & \\
\hline Gomphonema pseudosphaerophor & & & & & & & \\
\hline Gomphonema rhombicum (37080) & & & & & & & \\
\hline Gomphonema sarcophagus (37152 & & & & & & & \\
\hline Gomphonema truncatum (37022) & & & & & & & \\
\hline Karayevia laterostrata (125002) & 1 & 1 & & & 1 & & \\
\hline Karayevia ploenensis (125008) & & & & & & & \\
\hline Karayevia suchlandtii (125009) & 2 & 7 & 4 & 1 & 2 & 2 & 5 \\
\hline Navicula absoluta (46494) & & & & & & & \\
\hline Navicula cryptocephala (46014) & 1 & & 4 & 3 & 1 & 2 & \\
\hline Navicula difficillima (46017) & & & & & & & \\
\hline Navicula levanderii & & & & & & & \\
\hline Navicula prominula & & & & & & & \\
\hline Navicula pseudobryophila (46807) & & & & & & & \\
\hline Navicula pseudoventralis (46166) & & & & & & & \\
\hline Navicula schmassmannii (46066) & 1 & & & 1 & 1 & 2 & 4 \\
\hline Navicula striolata (93266) & & & & & & & \\
\hline Navicula subrotundata (46079) & & & & & & & \\
\hline Navicula trivalis & & & & & & & \\
\hline Navicula viridula (46408) & & & & & & & \\
\hline Neidium affine (47001) & & & & & & & \\
\hline Neidium ampliatum (47066) & & & & & & & \\
\hline Neidium dubium (47011) & & & & & & & \\
\hline Neidium hitchcockii (47028) & & & & & & & \\
\hline Neidium iridis (47014) & & & & 1 & & & \\
\hline Neidium septentrionalis (47110) & & & & & & & \\
\hline Nitzschia angustata (48093) & & & & & & & \\
\hline Nitzschia behrei (48585) & & & & & & & \\
\hline Nitzschia diversa (48411) & & & & & & & \\
\hline Nitzschia elegans (48010) & & & & & & & \\
\hline Nitzschia fonticola (48011) & 13 & 7 & 5 & 5 & 6 & 3 & 9 \\
\hline Nitzschia gisela (48624) & & & & & & & \\
\hline Nitzschia graciliformis (48119) & & & & & & & \\
\hline Nitzschia gracilis (48015) & & & 1 & & & 1 & \\
\hline Nitzschia recta (48029) & & & & & & & \\
\hline Nitzschia tropica (48045) & & & & & & & \\
\hline
\end{tabular}




\begin{tabular}{|c|c|c|c|c|c|c|c|}
\hline \multirow[b]{2}{*}{ Updated Species Name } & \multicolumn{7}{|c|}{ Depth (cm) } \\
\hline & 13.0 & 13.3 & 13.9 & 14.2 & 14.8 & 15.1 & 15.7 \\
\hline \multicolumn{8}{|l|}{ Nupela gracillima (92026) } \\
\hline \multicolumn{8}{|l|}{ Oxyneis binalis (9107001) } \\
\hline \multicolumn{8}{|l|}{ Pinnularia alpina (52807) } \\
\hline \multicolumn{8}{|l|}{ Pinnularia appendiculata (52009) } \\
\hline \multicolumn{8}{|l|}{ Pinnularia borealis (52013) } \\
\hline \multicolumn{8}{|l|}{ Pinnularia brauniana (103001) } \\
\hline \multicolumn{8}{|l|}{ Pinnularia divergens (52025) } \\
\hline \multicolumn{8}{|l|}{ Pinnularia episcopalis } \\
\hline \multicolumn{8}{|l|}{ Pinnularia gibba (52159) } \\
\hline \multicolumn{8}{|l|}{ Pinnularia interrupta (52194) } \\
\hline \multicolumn{8}{|l|}{ Pinnularia karelica } \\
\hline Pinnularia microstauron (52045) & 1 & & & & & & \\
\hline \multicolumn{8}{|l|}{ Pinnularia nobilis (103038) } \\
\hline \multicolumn{8}{|l|}{ Pinnularia nodosa (52048) } \\
\hline \multicolumn{8}{|l|}{ Pinnularia polyonca (52087) } \\
\hline \multicolumn{8}{|l|}{ Pinnularia polyonca (52087) } \\
\hline \multicolumn{8}{|l|}{ Pinnularia pulchra (52801) } \\
\hline Pinnularia subcapitata (52059) & 1 & & 3 & 3 & 2 & 1 & 1 \\
\hline \multicolumn{8}{|l|}{ Pinnularia subrostrata (52184) } \\
\hline \multicolumn{8}{|l|}{ Pinnularia superdiverdentissima } \\
\hline Pinnularia viridis (52071) & & 2 & & 1 & & 1 & \\
\hline \multicolumn{8}{|l|}{ Placoneis elginensis (194005) } \\
\hline \multicolumn{8}{|l|}{ Planothidium joursacense (155016) } \\
\hline \multicolumn{8}{|l|}{ Planothidium oestrupii (155026) } \\
\hline \multicolumn{8}{|l|}{ Platessa holsatica (2508002) } \\
\hline Psammothidium curtissimum (186021) & 1 & 1 & 1 & 1 & 4 & 1 & \\
\hline \multicolumn{5}{|l|}{ Psammothidium didymum (186012) } & 1 & 1 & \\
\hline \multicolumn{8}{|l|}{ Psammothidium helveticum (186003) } \\
\hline Psammothidium ventralis (186009) & 2 & & 1 & & & & \\
\hline Pseudostaurosira brevistriata (73001) & 20 & 24 & 27 & 14 & 15 & 14 & 26 \\
\hline Pseudostaurosira elliptica (73025) & 2 & 4 & 1 & 1 & 7 & 4 & 4 \\
\hline Pseudostaurosira pseudoconstruens (73002) & & 4 & & & 2 & 3 & 6 \\
\hline Puncticulata bodanica (208004) & 2 & 3 & 3 & 1 & 2 & 3 & 3 \\
\hline Reimeria sinuata (55002) & & & & & & & \\
\hline Rossithidium nodosum (189006) & & & 2 & 2 & & & \\
\hline Rossithidium pusillum (189003) & 5 & 8 & 2 & 3 & 7 & 4 & 8 \\
\hline Sellaphora pupula (170006) & 5 & 3 & 6 & 3 & 5 & 4 & 3 \\
\hline
\end{tabular}


Depth (cm)

Updated Species Name

$\begin{array}{lllllll}13.0 & 13.3 & 13.9 & 14.2 & 14.8 & 15.1 & 15.7\end{array}$

Stauroneis acuta (62036)

Stauroneis anceps (62002)

Stauroneis cf. javanica (62045)

Stauroneis cf. schimanskii (62127)

Stauroneis phoenicenteron (62015)

Stauroneis producta (62017)

Stauroneis prominula (62069)

$\begin{array}{lllll}1 & 1 & 1 & 2 & 1 \\ & & 1\end{array}$

Stauroneis thermicola (62040)

Staurosira construens (172001)

Staurosira construens var. binodis (172005)

Staurosira construens var. exigua (172022)

$\begin{array}{lllllll} & 1 & 1 & 1 & & & \\ 5 & 8 & 5 & 5 & 4 & 5 & 2 \\ 40 & 48 & 28 & 30 & 24 & 35 & 16 \\ 11 & 12 & 7 & 9 & 7 & 4 & 9\end{array}$

Staurosira construens var. venter (172006)

Staurosirella lapponica (175002)

$\begin{array}{llllllll}\text { Staurosirella leptostauron var. rhomboides (175017) } & 2 & 3 & 9 & 4 & 1 & 2 & 4 \\ \text { Staurosirella pinnata (175005) } & 2 & 5 & 4 & 4 & & 2 & 4\end{array}$

Stenopterobia anceps (63003)

Stenopterobia delicatissima (63007)

Surirella amphioxys (65069)

Surirella angusta (65002)

Surirella elegans (65072)

1

Surirella gracilis (65013)

Surirella linearis (65014)

Tabellaria fenestrata (67002)

Tabellaria flocculosa (67004)

Tabularia fasciculata (200002)

Tetracyclus glans (71006)

Tetracyclus lacustris (71003)

\begin{tabular}{llllllll}
\hline \hline Total chrysophyte cysts per slice & 44 & 83 & 57 & 44 & 53 & 34 & 62 \\
Total diatom counts per slice & 446 & 498 & 455 & 441 & 470 & 412 & 462 \\
Total microspheres per slice & 123 & & 22 & & 160 & & 38
\end{tabular}




\begin{tabular}{|c|c|c|c|c|c|c|c|}
\hline & Dept & (cm) & & & & & \\
\hline Updated Species Name & 16.0 & 16.6 & 16.9 & $\mathbf{1 7 . 5}$ & $\mathbf{1 7 . 8}$ & 18.4 & 18.7 \\
\hline Achnanthes imperfecta (2051) & & & & & & & \\
\hline Achnanthes levanderi (2022) & 3 & 3 & 4 & 8 & 3 & 6 & 3 \\
\hline Achnanthes pergalli & & & & & & & \\
\hline Achnanthes pseudoswazi (2206) & 1 & & & & & 1 & \\
\hline Achnanthes trinodis (2109) & & & & & & & \\
\hline Achnanthidium minutissimum (1010) & 18 & 15 & 14 & 22 & 20 & 25 & 10 \\
\hline Achnanthidium semiapertum (1028) & & & & & & & \\
\hline Amphipleura lindheimerii & & & & & 1 & & \\
\hline Amphora copulata (7075) & & & & & & & \\
\hline Amphora ovalis (7001) & & & 2 & & & & \\
\hline Aulacoseira alpigena (10028) & 154 & 176 & 141 & 97 & 144 & 95 & 144 \\
\hline Aulacoseira ambigua (10008) & & & & 3 & & & \\
\hline Aulacoseira canadensis (10003) & & & & & & & \\
\hline Aulacoseira crassipunctata (10001) & & & & & & & \\
\hline Aulacoseira distans (10009) & 24 & 30 & 13 & 10 & 22 & 45 & 8 \\
\hline Aulacoseira granulata (10018) & & & & & & & \\
\hline Aulacoseira italica (10019) & & & & & & & \\
\hline Aulacoseira lacustris (10060) & 33 & 34 & 37 & 36 & 24 & 27 & 41 \\
\hline Aulacoseira lirata (10012) & & & & & & & \\
\hline Aulacoseira muzzanensis (10031) & & & & & & & \\
\hline Aulacoseira perglabra (10006) & 14 & 7 & 15 & 11 & 11 & 7 & 6 \\
\hline Aulacoseira subarctica (10015) & 2 & 1 & 0 & 2 & 1 & & 2 \\
\hline Aulacoseira tethera (10033) & 1 & & 3 & 1 & & & \\
\hline Aulacoseira valida (10029) & & & & & & & \\
\hline Bacillaria paradoxa (76001) & & & & 2 & & & \\
\hline Brachysira brebissonii (18005) & 5 & 5 & 9 & 4 & 12 & 7 & 6 \\
\hline Brachysira microcephala (18013) & & 1 & 1 & & & 1 & \\
\hline Caloneis alpestris (12025) & & & & & & & \\
\hline Caloneis lauta (12026) & & & & & & & \\
\hline Caloneis permagna (12030) & & & & & & & \\
\hline Caloneis silicula (12010) & & & & & & & \\
\hline Caloneis tenuis (12013) & & & & & & & \\
\hline Caloneis thermalis (12054) & & & & & & & \\
\hline Caloneis undulata (12022) & & & & & & & \\
\hline Caloneis westii (12056) & & & & & & & \\
\hline Cavinula cocconeiformis (195001) & & 5 & & 1 & 3 & 2 & \\
\hline Cavinula pseudoscutiformis (195003) & 2 & 2 & 7 & 1 & 1 & 1 & 5 \\
\hline
\end{tabular}




\begin{tabular}{|c|c|c|c|c|c|c|c|}
\hline \multirow[b]{2}{*}{ Updated Species Name } & \multicolumn{7}{|c|}{ Depth (cm) } \\
\hline & 16.0 & 16.6 & 16.9 & $\mathbf{1 7 . 5}$ & 17.8 & 18.4 & 18.7 \\
\hline Chamaepinnularia mediocris (212005) & & 3 & & & & & \\
\hline \multicolumn{8}{|l|}{ Chamaepinnularia soehrensis (212006) } \\
\hline \multicolumn{8}{|l|}{ Cocconeis placentula (16004) } \\
\hline Craticula halophila (21005) & 1 & & & & 1 & & \\
\hline \multicolumn{8}{|l|}{ Craticula riparia (21016) } \\
\hline Cyclotella comensis (20023) & 1 & 1 & & 1 & & & \\
\hline \multicolumn{8}{|l|}{ Cyclotella krammeri (20083) } \\
\hline Cyclotella ocellata (20009) & 39 & 25 & 34 & 26 & 32 & 49 & 35 \\
\hline Cyclotella rossii (20019) & 4 & & 1 & 1 & & 1 & \\
\hline Cyclotella tripartita (20085) & 13 & 3 & 6 & 6 & 4 & 9 & 7 \\
\hline \multicolumn{8}{|l|}{ Cymbella affinis (23073) } \\
\hline \multicolumn{8}{|l|}{ Cymbella amphicephala (23001) } \\
\hline \multicolumn{8}{|l|}{ Cymbella cesatii (23004) } \\
\hline \multicolumn{8}{|l|}{ Cymbella cistula (23005) } \\
\hline \multicolumn{8}{|l|}{ Cymbella helvetica (23099) } \\
\hline Cymbella heteropleura (23100) & & & & & & & 1 \\
\hline \multicolumn{8}{|l|}{ Cymbella lapponica (23116) } \\
\hline \multicolumn{8}{|l|}{ Cymbella rupicola (23020) } \\
\hline \multicolumn{8}{|l|}{ Cymbella schimanskii } \\
\hline Cymbella sileiaca & 1 & 3 & 4 & 4 & 2 & 16 & 2 \\
\hline \multicolumn{8}{|l|}{ Cymbella tumidula (23082) } \\
\hline \multicolumn{8}{|l|}{ Cymbella tynnii (47141) } \\
\hline \multicolumn{8}{|l|}{ Cymbopleura angustata (190013) } \\
\hline \multicolumn{8}{|l|}{ Cymbopleura cuspidata (190001) } \\
\hline \multicolumn{8}{|l|}{ Cymbopleura subaequalis (190017) } \\
\hline \multicolumn{8}{|l|}{ Denticula elegans (25001) } \\
\hline \multicolumn{8}{|l|}{ Denticula keutzingii } \\
\hline \multicolumn{8}{|l|}{ Diatoma mesodon (27002) } \\
\hline \multicolumn{8}{|l|}{ Diatoma vulgaris (27013) } \\
\hline \multicolumn{8}{|l|}{ Diploneis boldtiana (30012) } \\
\hline \multicolumn{8}{|l|}{ Diploneis elliptica (30001) } \\
\hline \multicolumn{8}{|l|}{ Diploneis finnica (30002) } \\
\hline Diploneis marginestriata (30003) & 4 & & 1 & 1 & & & 1 \\
\hline Diploneis ovalis (30009) & & & 1 & & & & \\
\hline Diploneis parma (30014) & 3 & & 3 & 1 & & & \\
\hline Discostella pseudostelligera (2506002) & 13 & 22 & 20 & 2 & 16 & 11 & 6 \\
\hline Discostella stelligera (2506003) & 3 & & & 17 & & 13 & \\
\hline
\end{tabular}




\begin{tabular}{|c|c|c|c|c|c|c|c|}
\hline \multirow[b]{2}{*}{ Updated Species Name } & \multicolumn{7}{|c|}{ Depth (cm) } \\
\hline & 16.0 & 16.6 & 16.9 & 17.5 & 17.8 & 18.4 & 18.7 \\
\hline Encyonema elginense (110044) & & & & & 1 & & 1 \\
\hline Encyonema gaeumannii (110008) & 4 & 5 & 3 & 8 & 1 & 4 & 1 \\
\hline \multicolumn{8}{|l|}{ Encyonema neogracile (110045) } \\
\hline Encyonopsis descripta (203014) & & & & & & 2 & \\
\hline \multicolumn{8}{|l|}{ Encyonopsis falaisensis (203007) } \\
\hline \multicolumn{8}{|l|}{ Encyonopsis microcephala (203002) } \\
\hline Encyonopsis minuta (203011) & 2 & 1 & 3 & 3 & 3 & 1 & \\
\hline \multicolumn{8}{|l|}{ Epithemia adnata (32003) } \\
\hline Epithemia smithii (32002) & & & 1 & 1 & & & \\
\hline \multicolumn{8}{|l|}{ Epithemia sorex (32006) } \\
\hline Eucocconeis flexella (187001) & & & & & 2 & & 1 \\
\hline \multicolumn{8}{|l|}{ Eucocconeis laevis (187002) } \\
\hline Eunotia arcus (33001) & 1 & 2 & & & 2 & 1 & \\
\hline Eunotia bigibba (33005) & 1 & & & & 1 & 1 & \\
\hline Eunotia bilunaris (33185) & & 2 & & 2 & & & \\
\hline \multicolumn{8}{|l|}{ Eunotia circumborealis (33210) } \\
\hline \multicolumn{8}{|l|}{ Eunotia denticulata (33011) } \\
\hline Eunotia exigua (33015) & & & & & & 1 & \\
\hline Eunotia faba (33172) & 3 & 3 & 7 & 5 & 5 & 2 & 3 \\
\hline \multicolumn{8}{|l|}{ Eunotia implicata (33168) } \\
\hline Eunotia incisa (33026) & & 1 & & & & 2 & \\
\hline \multicolumn{8}{|l|}{ Eunotia minor (33183) } \\
\hline \multicolumn{8}{|l|}{ Eunotia monodon (33035) } \\
\hline \multicolumn{8}{|l|}{ Eunotia muscicola (33184) } \\
\hline \multicolumn{8}{|l|}{ Eunotia paludosa (33083) } \\
\hline \multicolumn{8}{|l|}{ Eunotia pectinalis (33039) } \\
\hline \multicolumn{8}{|l|}{ Eunotia praerupta (33045) } \\
\hline Eunotia rhomboidea (33051) & & & 1 & & & & \\
\hline \multicolumn{8}{|l|}{ Eunotia rhynchocephala (33191) } \\
\hline Eunotia septentrionalis (33053) & & & 1 & & & & \\
\hline Eunotia serra (33054) & & & 2 & & & & \\
\hline \multicolumn{8}{|l|}{ Eunotia soleirolii (33056) } \\
\hline Fragilaria capucina (34006) & 2 & & & & 1 & 1 & \\
\hline \multicolumn{8}{|l|}{ Fragilaria delicatissima } \\
\hline Frustulia krammeri (35039) & 4 & & 3 & 1 & 2 & 2 & 4 \\
\hline \multicolumn{8}{|l|}{ Gomphonema acuminatum (37001) } \\
\hline Gomphonema angustatum (37003) & 2 & 1 & 1 & 4 & 1 & & 1 \\
\hline
\end{tabular}




\begin{tabular}{|c|c|c|c|c|c|c|c|}
\hline & Deptl & (cm) & & & & & \\
\hline Updated Species Name & 16.0 & 16.6 & 16.9 & 17.5 & 17.8 & 18.4 & 18.7 \\
\hline Gomphonema olivaceum (37065) & & & & & & & \\
\hline Gomphonema parvulum (37010) & & & & 4 & & & \\
\hline Gomphonema pseudosphaerophor & & & & & & & \\
\hline Gomphonema rhombicum (37080) & & & & & & & \\
\hline Gomphonema sarcophagus (3715 & & & & & & & \\
\hline Gomphonema truncatum (37022) & & & & & & & \\
\hline Karayevia laterostrata (125002) & & & & & & 2 & 1 \\
\hline Karayevia ploenensis (125008) & & & & & & & \\
\hline Karayevia suchlandtii (125009) & 3 & 1 & 2 & & & 1 & 5 \\
\hline Navicula absoluta (46494) & & & & & & & \\
\hline Navicula cryptocephala (46014) & 3 & 1 & 1 & & 1 & 1 & 3 \\
\hline Navicula difficillima (46017) & & & & & & & \\
\hline Navicula levanderii & & & & & & & \\
\hline Navicula prominula & & & & 1 & & & \\
\hline Navicula pseudobryophila (46807 & & & & & & & \\
\hline Navicula pseudoventralis (46166) & & & & & & & \\
\hline Navicula schmassmannii (46066) & & & & 2 & & 2 & \\
\hline Navicula striolata (93266) & & & & 1 & & & \\
\hline Navicula subrotundata (46079) & & & & & & & \\
\hline Navicula trivalis & & & & & & & \\
\hline Navicula viridula (46408) & & & & & & & \\
\hline Neidium affine (47001) & & & & & & & \\
\hline Neidium ampliatum (47066) & 2 & 1 & 1 & & & & \\
\hline Neidium dubium (47011) & & & & & & & \\
\hline Neidium hitchcockii (47028) & & & & & & & \\
\hline Neidium iridis (47014) & & & & & & & 1 \\
\hline Neidium septentrionalis (47110) & & & & & & & \\
\hline Nitzschia angustata (48093) & 2 & 1 & & & & & \\
\hline Nitzschia behrei (48585) & & & & & & & \\
\hline Nitzschia diversa (48411) & & & & & & & \\
\hline Nitzschia elegans (48010) & & & & & & & \\
\hline Nitzschia fonticola (48011) & 6 & 7 & 9 & 3 & 9 & 8 & 4 \\
\hline Nitzschia gisela (48624) & & & & & & & \\
\hline Nitzschia graciliformis (48119) & & & & & & & \\
\hline Nitzschia gracilis (48015) & & & & & 1 & & \\
\hline Nitzschia recta (48029) & & & & & & & \\
\hline Nitzschia tropica (48045) & & & & & & & \\
\hline
\end{tabular}




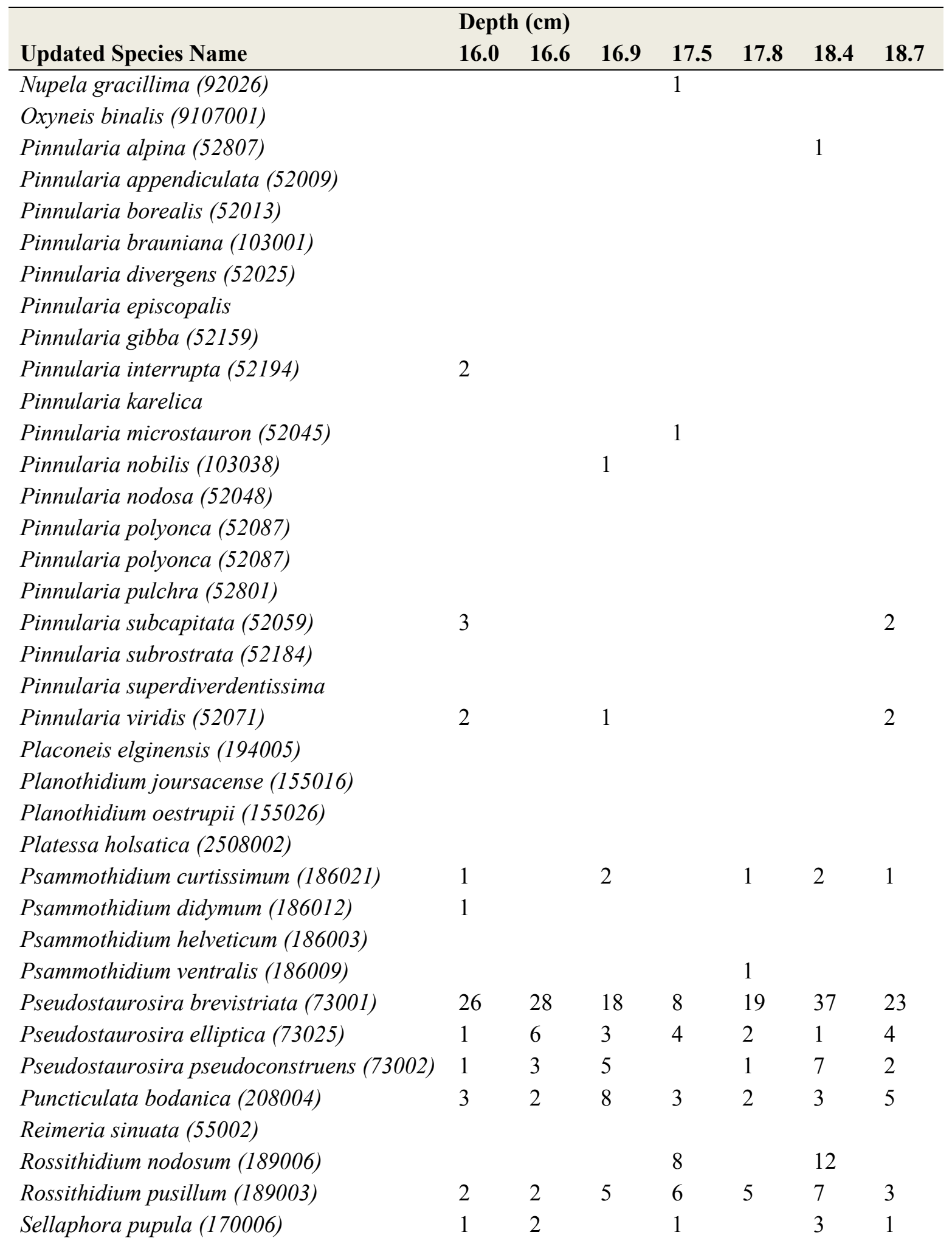


Depth (cm)

Updated Species Name

$\begin{array}{lllllll}16.0 & 16.6 & 16.9 & 17.5 & 17.8 & 18.4 & 18.7\end{array}$

Stauroneis acuta (62036)

Stauroneis anceps (62002)

2

Stauroneis cf. javanica (62045)

Stauroneis cf. schimanskii (62127)

Stauroneis phoenicenteron (62015)

Stauroneis producta (62017)

$\begin{array}{lllllll}2 & & & 1 & & 2 & \\ 1 & 3 & 3 & & 1 & & 2\end{array}$

Stauroneis prominula (62069)

Stauroneis thermicola (62040)

Staurosira construens (172001)

Staurosira construens var. binodis (172005)

Staurosira construens var. exigua (172022)

$\begin{array}{lllllll}14 & 3 & 4 & 4 & 6 & 6 & 11 \\ 32 & 26 & 45 & 34 & 20 & 37 & 32 \\ 3 & 10 & 5 & 27 & 9 & 14 & 11\end{array}$

Staurosira construens var. venter (172006)

Staurosirella lapponica (175002)

Staurosirella leptostauron var. rhomboides (175017) 4

Staurosirella pinnata (175005)

$\begin{array}{lllllll}4 & & 3 & 1 & 2 & 2 & 4 \\ 3 & 4 & 3 & 7 & 3 & 10 & 3\end{array}$

Stenopterobia anceps (63003)

Stenopterobia delicatissima (63007)

Surirella amphioxys (65069)

Surirella angusta (65002)

Surirella elegans (65072)

Surirella gracilis (65013)

Surirella linearis (65014)

Tabellaria fenestrata (67002)

Tabellaria flocculosa (67004)

Tabularia fasciculata (200002)

Tetracyclus glans (71006)

$\begin{array}{lllllll}2 & & 1 & & & & \\ 4 & 1 & 4 & 1 & 1 & 3 & 4 \\ 4 & 2 & 8 & 9 & 6 & 6 & 4\end{array}$

Tetracyclus lacustris (71003)

\begin{tabular}{llllllll}
\hline \hline Total chrysophyte cysts per slice & 64 & 36 & 46 & 64 & 44 & 74 & 17 \\
Total diatom counts per slice & 489 & 454 & 471 & 415 & 407 & 502 & 417 \\
Total microspheres per slice & & 54 & & 224 & & 240 &
\end{tabular}




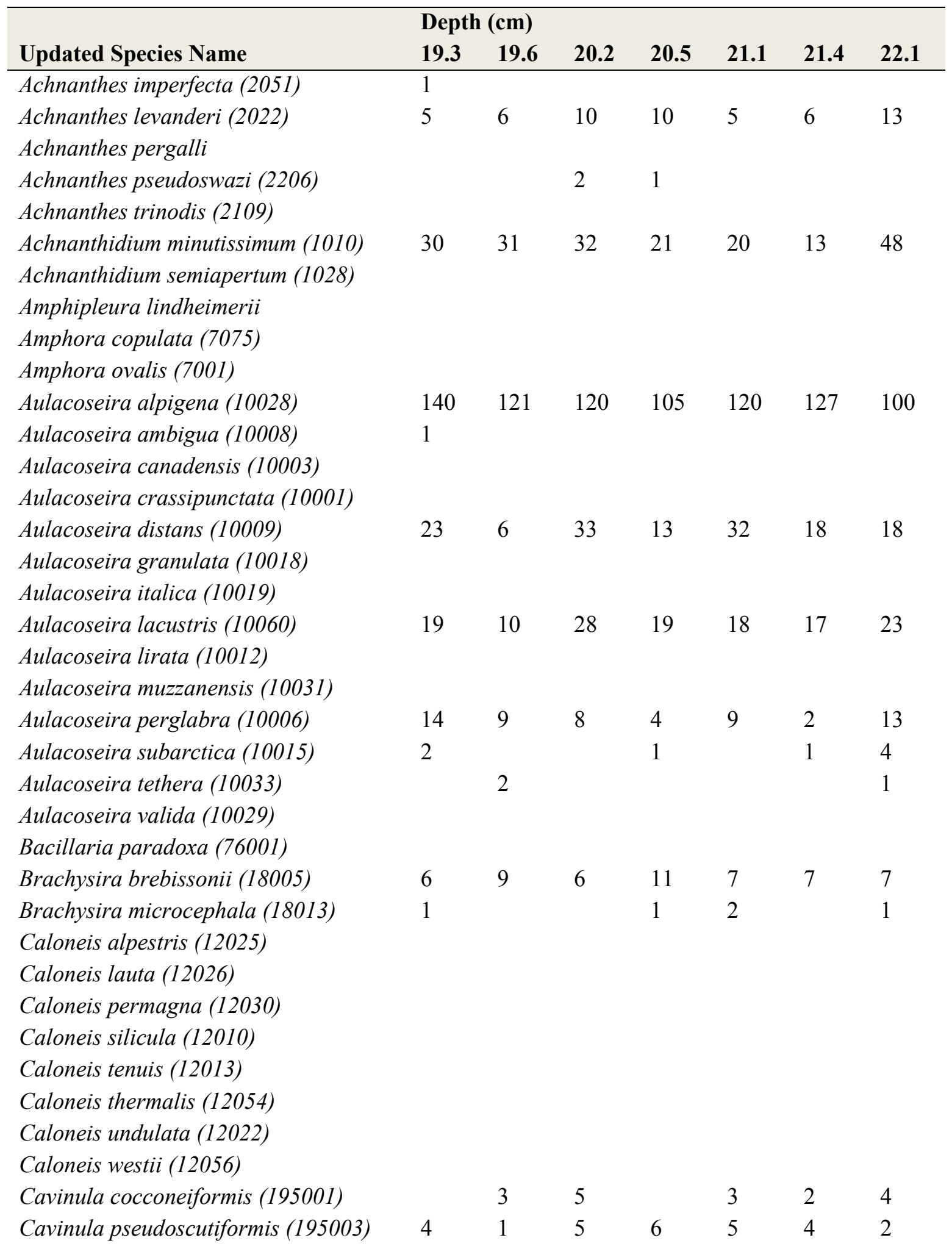




\begin{tabular}{|c|c|c|c|c|c|c|c|}
\hline \multirow[b]{2}{*}{ Updated Species Name } & \multicolumn{7}{|c|}{ Depth (cm) } \\
\hline & 19.3 & 19.6 & 20.2 & 20.5 & 21.1 & 21.4 & 22.1 \\
\hline Chamaepinnularia mediocris (212005) & & & 2 & 1 & 1 & & \\
\hline \multicolumn{8}{|l|}{ Chamaepinnularia soehrensis (212006) } \\
\hline \multicolumn{8}{|l|}{ Cocconeis placentula (16004) } \\
\hline Craticula halophila (21005) & & & 1 & 1 & & & \\
\hline \multicolumn{8}{|l|}{ Craticula riparia (21016) } \\
\hline Cyclotella comensis (20023) & 1 & & & 2 & & & \\
\hline \multicolumn{8}{|l|}{ Cyclotella krammeri (20083) } \\
\hline Cyclotella ocellata (20009) & 18 & 50 & 16 & 33 & 29 & 52 & 38 \\
\hline Cyclotella rossii (20019) & 2 & 1 & 1 & & & & 2 \\
\hline Cyclotella tripartita (20085) & 4 & 9 & 5 & 4 & 2 & & 6 \\
\hline \multicolumn{8}{|l|}{ Cymbella affinis (23073) } \\
\hline \multicolumn{8}{|l|}{ Cymbella amphicephala (23001) } \\
\hline \multicolumn{8}{|l|}{ Cymbella cesatii (23004) } \\
\hline \multicolumn{8}{|l|}{ Cymbella cistula (23005) } \\
\hline Cymbella helvetica (23099) & & & & & & 1 & \\
\hline \multicolumn{8}{|l|}{ Cymbella heteropleura (23100) } \\
\hline \multicolumn{8}{|l|}{ Cymbella lapponica (23116) } \\
\hline \multicolumn{8}{|l|}{ Cymbella rupicola (23020) } \\
\hline \multicolumn{8}{|l|}{ Cymbella schimanskii } \\
\hline Cymbella sileiaca & 1 & 9 & 2 & 2 & 5 & 6 & 4 \\
\hline \multicolumn{8}{|l|}{ Cymbella tumidula (23082) } \\
\hline \multicolumn{8}{|l|}{ Cymbella tynnii (47141) } \\
\hline \multicolumn{8}{|l|}{ Cymbopleura angustata (190013) } \\
\hline \multicolumn{8}{|l|}{ Cymbopleura cuspidata (190001) } \\
\hline \multicolumn{8}{|l|}{ Cymbopleura subaequalis (190017) } \\
\hline \multicolumn{8}{|l|}{ Denticula elegans (25001) } \\
\hline \multicolumn{8}{|l|}{ Denticula keutzingii } \\
\hline \multicolumn{8}{|l|}{ Diatoma mesodon (27002) } \\
\hline \multicolumn{8}{|l|}{ Diatoma vulgaris (27013) } \\
\hline \multicolumn{8}{|l|}{ Diploneis boldtiana (30012) } \\
\hline \multicolumn{8}{|l|}{ Diploneis elliptica (30001) } \\
\hline \multicolumn{8}{|l|}{ Diploneis finnica (30002) } \\
\hline Diploneis marginestriata (30003) & 1 & 2 & & 2 & 1 & 1 & 1 \\
\hline Diploneis ovalis (30009) & & & & & & & \\
\hline Diploneis parma (30014) & & & & 1 & & 1 & \\
\hline Discostella pseudostelligera (2506002) & 12 & 9 & 20 & 21 & 23 & 24 & 20 \\
\hline Discostella stelligera (2506003) & & 9 & 1 & 3 & 1 & 2 & 8 \\
\hline
\end{tabular}




\begin{tabular}{|c|c|c|c|c|c|c|c|}
\hline \multirow[b]{2}{*}{ Updated Species Name } & \multicolumn{7}{|c|}{ Depth (cm) } \\
\hline & 19.3 & 19.6 & 20.2 & 20.5 & 21.1 & 21.4 & 22.1 \\
\hline \multicolumn{8}{|l|}{ Encyonema elginense (110044) } \\
\hline Encyonema gaeumannii (110008) & 5 & 4 & 4 & 5 & 10 & 1 & 5 \\
\hline \multicolumn{8}{|l|}{ Encyonema neogracile (110045) } \\
\hline Encyonopsis descripta (203014) & 1 & 1 & & 1 & 1 & & \\
\hline \multicolumn{8}{|l|}{ Encyonopsis falaisensis (203007) } \\
\hline \multicolumn{8}{|l|}{ Encyonopsis microcephala (203002) } \\
\hline Encyonopsis minuta (203011) & 2 & 3 & 2 & & 3 & 5 & 1 \\
\hline \multicolumn{8}{|l|}{ Epithemia adnata (32003) } \\
\hline \multicolumn{8}{|l|}{ Epithemia smithii (32002) } \\
\hline \multicolumn{8}{|l|}{ Epithemia sorex (32006) } \\
\hline Eucocconeis flexella (187001) & & & & & 3 & 2 & \\
\hline Eucocconeis laevis (187002) & & & & & & & 3 \\
\hline Eunotia arcus (33001) & 2 & 1 & & & 3 & & \\
\hline \multicolumn{8}{|l|}{ Eunotia bigibba (33005) } \\
\hline Eunotia bilunaris (33185) & 2 & 3 & 2 & & & 1 & 1 \\
\hline \multicolumn{8}{|l|}{ Eunotia circumborealis (33210) } \\
\hline \multicolumn{8}{|l|}{ Eunotia denticulata (33011) } \\
\hline \multicolumn{8}{|l|}{ Eunotia exigua (33015) } \\
\hline Eunotia faba (33172) & & 8 & 3 & 2 & 3 & 5 & 5 \\
\hline \multicolumn{8}{|l|}{ Eunotia implicata (33168) } \\
\hline Eunotia incisa (33026) & & 2 & & & & 1 & \\
\hline \multicolumn{8}{|l|}{ Eunotia minor (33183) } \\
\hline \multicolumn{8}{|l|}{ Eunotia monodon (33035) } \\
\hline \multicolumn{8}{|l|}{ Eunotia muscicola (33184) } \\
\hline \multicolumn{8}{|l|}{ Eunotia paludosa (33083) } \\
\hline \multicolumn{8}{|l|}{ Eunotia pectinalis (33039) } \\
\hline \multicolumn{8}{|l|}{ Eunotia praerupta (33045) } \\
\hline \multicolumn{8}{|l|}{ Eunotia rhomboidea (33051) } \\
\hline \multicolumn{8}{|l|}{ Eunotia rhynchocephala (33191) } \\
\hline \multicolumn{8}{|l|}{ Eunotia septentrionalis (33053) } \\
\hline Eunotia serra (33054) & & & & & & 1 & \\
\hline Eunotia soleirolii (33056) & 1 & 1 & & & & & \\
\hline Fragilaria capucina (34006) & 1 & 2 & 2 & & & 1 & 2 \\
\hline \multicolumn{8}{|l|}{ Fragilaria delicatissima } \\
\hline Frustulia krammeri (35039) & 4 & 4 & 2 & 4 & 4 & 3 & 5 \\
\hline \multicolumn{8}{|l|}{ Gomphonema acuminatum (37001) } \\
\hline Gomphonema angustatum (37003) & & 1 & & 1 & 1 & 2 & 1 \\
\hline
\end{tabular}




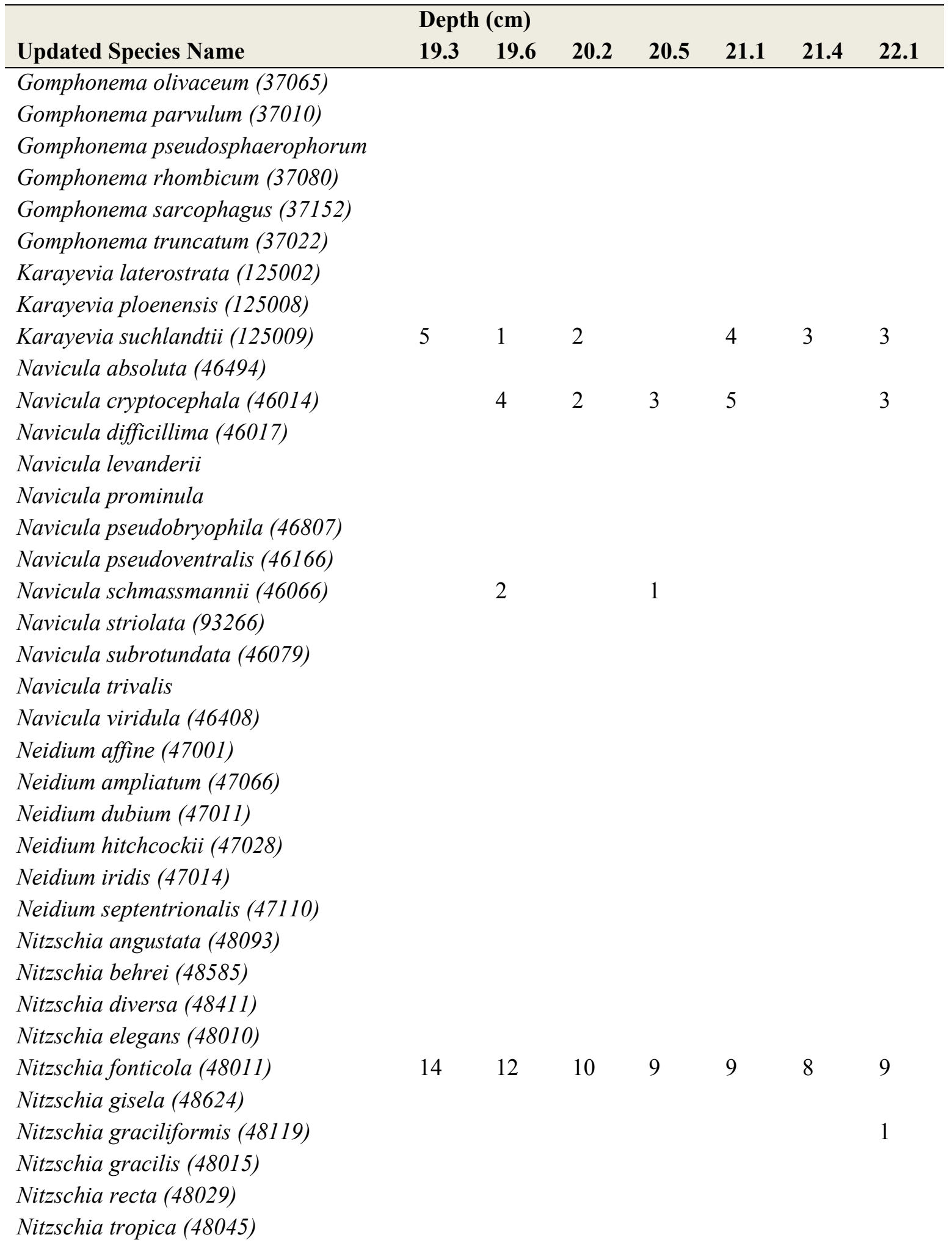




\begin{tabular}{|c|c|c|c|c|c|c|c|}
\hline \multirow[b]{2}{*}{ Updated Species Name } & \multicolumn{2}{|c|}{ Depth (cm) } & \multirow[b]{2}{*}{20.2} & \multirow[b]{2}{*}{20.5} & \multirow[b]{2}{*}{21.1} & \multirow[b]{2}{*}{21.4} & \multirow[b]{2}{*}{22.1} \\
\hline & 19.3 & 19.6 & & & & & \\
\hline \multicolumn{8}{|l|}{ Nupela gracillima (92026) } \\
\hline \multicolumn{8}{|l|}{ Oxyneis binalis (9107001) } \\
\hline \multicolumn{8}{|l|}{ Pinnularia alpina (52807) } \\
\hline \multicolumn{8}{|l|}{ Pinnularia appendiculata (52009) } \\
\hline \multicolumn{8}{|l|}{ Pinnularia borealis (52013) } \\
\hline \multicolumn{8}{|l|}{ Pinnularia brauniana (103001) } \\
\hline \multicolumn{8}{|l|}{ Pinnularia divergens (52025) } \\
\hline \multicolumn{8}{|l|}{ Pinnularia episcopalis } \\
\hline \multicolumn{8}{|l|}{ Pinnularia gibba (52159) } \\
\hline \multicolumn{8}{|l|}{ Pinnularia interrupta (52194) } \\
\hline \multicolumn{8}{|l|}{ Pinnularia karelica } \\
\hline \multicolumn{8}{|l|}{ Pinnularia microstauron (52045) } \\
\hline \multicolumn{8}{|l|}{ Pinnularia nobilis (103038) } \\
\hline \multicolumn{8}{|l|}{ Pinnularia nodosa (52048) } \\
\hline \multicolumn{8}{|l|}{ Pinnularia polyonca (52087) } \\
\hline \multicolumn{8}{|l|}{ Pinnularia polyonca (52087) } \\
\hline \multicolumn{8}{|l|}{ Pinnularia pulchra (52801) } \\
\hline Pinnularia subcapitata (52059) & 1 & 2 & & 1 & 1 & 1 & \\
\hline \multicolumn{8}{|l|}{ Pinnularia subrostrata (52184) } \\
\hline \multicolumn{8}{|l|}{ Pinnularia superdiverdentissima } \\
\hline Pinnularia viridis (52071) & & & 1 & 2 & & & \\
\hline Placoneis elginensis (194005) & & & & & & & \\
\hline Planothidium joursacense (155016) & & & & & & & \\
\hline Planothidium oestrupii (155026) & & & & & & & \\
\hline Platessa holsatica (2508002) & & & & & & & \\
\hline Psammothidium curtissimum (186021) & 2 & & 2 & 7 & 4 & 1 & 5 \\
\hline Psammothidium didymum (186012) & & & & 2 & 1 & & \\
\hline Psammothidium helveticum (186003) & & & & & & & \\
\hline Psammothidium ventralis (186009) & & & & & & & \\
\hline Pseudostaurosira brevistriata (73001) & 26 & 22 & 44 & 26 & 23 & 33 & 24 \\
\hline Pseudostaurosira elliptica (73025) & 5 & & 1 & 4 & 8 & 5 & 5 \\
\hline Pseudostaurosira pseudoconstruens (73002) & 5 & 3 & & 1 & 2 & 4 & 3 \\
\hline Puncticulata bodanica (208004) & & 5 & 3 & 3 & 2 & 4 & 1 \\
\hline Reimeria sinuata (55002) & & & & & & & \\
\hline Rossithidium nodosum (189006) & & 4 & 1 & 5 & & & 2 \\
\hline Rossithidium pusillum (189003) & 9 & 8 & 8 & 5 & 8 & 8 & 9 \\
\hline Sellaphora pupula (170006) & 5 & 2 & 7 & & 2 & & 4 \\
\hline
\end{tabular}




\section{Depth (cm)}

Updated Species Name

$\begin{array}{lllllll}19.3 & 19.6 & 20.2 & 20.5 & 21.1 & 21.4 & 22.1\end{array}$

Stauroneis acuta (62036)

Stauroneis anceps (62002)

Stauroneis cf. javanica (62045)

Stauroneis cf. schimanskii (62127)

Stauroneis phoenicenteron (62015)

6

Stauroneis producta (62017)

Stauroneis prominula (62069)

\begin{tabular}{|c|c|c|c|c|c|c|}
\hline & & & 3 & 3 & 3 & 1 \\
\hline & & 1 & & 1 & & 4 \\
\hline 1 & & & & 1 & & 1 \\
\hline 4 & 6 & 4 & 11 & 4 & 11 & 8 \\
\hline 36 & 39 & 14 & 35 & 23 & 35 & 28 \\
\hline 11 & 9 & 15 & 16 & 13 & 12 & 18 \\
\hline
\end{tabular}

Staurosira construens var. venter (172006)

Staurosirella lapponica (175002)

Staurosirella leptostauron var. rhomboides (175017) $4 \begin{array}{llllllll}4 & 4 & 2 & 4 & 4 & 3 & 5\end{array}$

Staurosirella pinnata (175005)

$\begin{array}{lllllll}11 & 14 & 22 & 4 & 4 & 10 & 3\end{array}$

Stenopterobia anceps (63003)

Stenopterobia delicatissima (63007)

Surirella amphioxys (65069)

Surirella angusta (65002)

Surirella elegans (65072)

Surirella gracilis (65013)

Surirella linearis (65014)

Tabellaria fenestrata (67002)

Tabellaria flocculosa (67004)

$\begin{array}{lllllll}2 & 2 & 2 & 1 & 1 & 2 & 3 \\ 11 & 8 & 5 & 4 & 5 & 7 & 5\end{array}$

Tabularia fasciculata (200002)

Tetracyclus glans (71006)

Tetracyclus lacustris (71003)

\begin{tabular}{llllllll}
\hline \hline Total chrysophyte cysts per slice & 26 & 40 & 50 & 33 & 46 & 41 & 55 \\
Total diatom counts per slice & 456 & 470 & 458 & 422 & 439 & 456 & 483 \\
Total microspheres per slice & 41 & & 23 & & 62 & & 68
\end{tabular}




\begin{tabular}{|c|c|c|c|c|c|c|c|}
\hline \multirow[b]{2}{*}{ Updated Species Name } & \multicolumn{7}{|c|}{ Depth (cm) } \\
\hline & 22.4 & 23.0 & 23.3 & 23.9 & 24.2 & 24.9 & 25.3 \\
\hline \multicolumn{8}{|l|}{ Achnanthes imperfecta (2051) } \\
\hline Achnanthes levanderi (2022) & 4 & 9 & 11 & 12 & 2 & 9 & 3 \\
\hline \multicolumn{8}{|l|}{ Achnanthes pergalli } \\
\hline Achnanthes pseudoswazi (2206) & & & 1 & 1 & & & \\
\hline \multicolumn{8}{|l|}{ Achnanthes trinodis (2109) } \\
\hline Achnanthidium minutissimum (1010) & 15 & 22 & 40 & 42 & 15 & 30 & 24 \\
\hline \multicolumn{8}{|l|}{ Achnanthidium semiapertum (1028) } \\
\hline \multicolumn{8}{|l|}{ Amphipleura lindheimerii } \\
\hline \multicolumn{8}{|l|}{ Amphora copulata (7075) } \\
\hline Amphora ovalis (7001) & & & & & & & 1 \\
\hline Aulacoseira alpigena (10028) & 161 & 150 & 142 & 122 & 167 & 143 & 170 \\
\hline Aulacoseira ambigua (10008) & & & & 1 & & & \\
\hline Aulacoseira canadensis (10003) & & & & 2 & & & \\
\hline \multicolumn{8}{|l|}{ Aulacoseira crassipunctata (10001) } \\
\hline Aulacoseira distans (10009) & 15 & 12 & 3 & 40 & 16 & 22 & 8 \\
\hline \multicolumn{8}{|l|}{ Aulacoseira granulata (10018) } \\
\hline Aulacoseira italica (10019) & & 1 & & & & & \\
\hline Aulacoseira lacustris (10060) & 16 & 17 & 8 & 18 & 19 & 16 & \\
\hline \multicolumn{8}{|l|}{ Aulacoseira lirata (10012) } \\
\hline \multicolumn{8}{|l|}{ Aulacoseira muzzanensis (10031) } \\
\hline Aulacoseira perglabra (10006) & 6 & 9 & 7 & 22 & 4 & 7 & \\
\hline Aulacoseira subarctica (10015) & 2 & & & 2 & 1 & & \\
\hline \multicolumn{8}{|l|}{ Aulacoseira tethera (10033) } \\
\hline \multicolumn{8}{|l|}{ Aulacoseira valida (10029) } \\
\hline \multicolumn{8}{|l|}{ Bacillaria paradoxa (76001) } \\
\hline Brachysira brebissonii (18005) & 8 & 6 & 18 & 7 & 11 & 2 & 6 \\
\hline Brachysira microcephala (18013) & 3 & 2 & 1 & & 3 & 3 & 2 \\
\hline \multicolumn{8}{|l|}{ Caloneis alpestris (12025) } \\
\hline \multicolumn{8}{|l|}{ Caloneis lauta (12026) } \\
\hline Caloneis permagna (12030) & & & 1 & & & & \\
\hline \multicolumn{8}{|l|}{ Caloneis silicula (12010) } \\
\hline \multicolumn{8}{|l|}{ Caloneis tenuis (12013) } \\
\hline \multicolumn{8}{|l|}{ Caloneis thermalis (12054) } \\
\hline \multicolumn{8}{|l|}{ Caloneis undulata (12022) } \\
\hline Caloneis westii (12056) & & & & & 1 & & \\
\hline Cavinula cocconeiformis (195001) & 2 & 5 & 3 & & 1 & 3 & \\
\hline Cavinula pseudoscutiformis (195003) & 5 & 1 & 8 & 3 & 4 & 9 & 5 \\
\hline
\end{tabular}




\begin{tabular}{|c|c|c|c|c|c|c|c|}
\hline \multirow[b]{2}{*}{ Updated Species Name } & \multicolumn{7}{|c|}{ Depth (cm) } \\
\hline & 22.4 & 23.0 & 23.3 & 23.9 & 24.2 & 24.9 & 25.3 \\
\hline Chamaepinnularia mediocris (212005) & 1 & & & & & 1 & \\
\hline \multicolumn{8}{|l|}{ Chamaepinnularia soehrensis (212006) } \\
\hline \multicolumn{8}{|l|}{ Cocconeis placentula (16004) } \\
\hline Craticula halophila (21005) & & 1 & & & & & \\
\hline \multicolumn{8}{|l|}{ Craticula riparia (21016) } \\
\hline Cyclotella comensis (20023) & & 1 & & & & & \\
\hline \multicolumn{8}{|l|}{ Cyclotella krammeri (20083) } \\
\hline Cyclotella ocellata (20009) & 37 & 25 & 32 & 34 & 44 & 37 & 34 \\
\hline Cyclotella rossii (20019) & 1 & 1 & & 4 & 2 & & \\
\hline Cyclotella tripartita (20085) & 4 & 1 & 4 & 7 & 15 & 3 & 5 \\
\hline \multicolumn{8}{|l|}{ Cymbella affinis (23073) } \\
\hline Cymbella amphicephala (23001) & & & & 1 & & & \\
\hline \multicolumn{8}{|l|}{ Cymbella cesatii (23004) } \\
\hline \multicolumn{8}{|l|}{ Cymbella cistula (23005) } \\
\hline \multicolumn{8}{|l|}{ Cymbella helvetica (23099) } \\
\hline Cymbella heteropleura (23100) & & 1 & & & & & \\
\hline \multicolumn{8}{|l|}{ Cymbella lapponica (23116) } \\
\hline Cymbella rupicola (23020) & & & & 1 & & & \\
\hline \multicolumn{8}{|l|}{ Cymbella schimanskii } \\
\hline Cymbella sileiaca & 5 & 2 & 5 & 1 & 3 & 4 & 2 \\
\hline \multicolumn{8}{|l|}{ Cymbella tumidula (23082) } \\
\hline \multicolumn{8}{|l|}{ Cymbella tynnii (47141) } \\
\hline \multicolumn{8}{|l|}{ Cymbopleura angustata (190013) } \\
\hline \multicolumn{8}{|l|}{ Cymbopleura cuspidata (190001) } \\
\hline \multicolumn{8}{|l|}{ Cymbopleura subaequalis (190017) } \\
\hline \multicolumn{8}{|l|}{ Denticula elegans (25001) } \\
\hline Denticula keutzingii & & & & & 1 & 1 & \\
\hline \multicolumn{8}{|l|}{ Diatoma mesodon (27002) } \\
\hline Diatoma vulgaris (27013) & & & & 2 & & & \\
\hline \multicolumn{8}{|l|}{ Diploneis boldtiana (30012) } \\
\hline \multicolumn{8}{|l|}{ Diploneis elliptica (30001) } \\
\hline \multicolumn{8}{|l|}{ Diploneis finnica (30002) } \\
\hline Diploneis marginestriata (30003) & 1 & & & & & 1 & 1 \\
\hline Diploneis ovalis (30009) & & & & & & & 1 \\
\hline Diploneis parma (30014) & & 1 & & & & & \\
\hline Discostella pseudostelligera (2506002) & 19 & 19 & 1 & 14 & 11 & 13 & 13 \\
\hline Discostella stelligera (2506003) & & & 11 & 7 & 2 & 2 & 1 \\
\hline
\end{tabular}




\begin{tabular}{|c|c|c|c|c|c|c|c|}
\hline \multirow[b]{2}{*}{ Updated Species Name } & \multicolumn{7}{|c|}{ Depth (cm) } \\
\hline & 22.4 & 23.0 & 23.3 & 23.9 & 24.2 & 24.9 & 25.3 \\
\hline \multicolumn{8}{|l|}{ Encyonema elginense (110044) } \\
\hline Encyonema gaeumannii (110008) & 1 & 2 & 2 & 2 & 2 & 5 & \\
\hline \multicolumn{8}{|l|}{ Encyonema neogracile (110045) } \\
\hline Encyonopsis descripta (203014) & 1 & & & 4 & & & \\
\hline \multicolumn{8}{|l|}{ Encyonopsis falaisensis (203007) } \\
\hline \multicolumn{8}{|l|}{ Encyonopsis microcephala (203002) } \\
\hline Encyonopsis minuta (203011) & 1 & 2 & 1 & 2 & 1 & 2 & 2 \\
\hline \multicolumn{8}{|l|}{ Epithemia adnata (32003) } \\
\hline \multicolumn{8}{|l|}{ Epithemia smithii (32002) } \\
\hline \multicolumn{8}{|l|}{ Epithemia sorex (32006) } \\
\hline Eucocconeis flexella (187001) & 1 & & & 1 & 1 & & \\
\hline Eucocconeis laevis (187002) & & & & & 1 & & \\
\hline Eunotia arcus (33001) & 1 & & & & & & \\
\hline Eunotia bigibba (33005) & & & & & 1 & & \\
\hline Eunotia bilunaris (33185) & 1 & 1 & & 1 & & 2 & 3 \\
\hline \multicolumn{8}{|l|}{ Eunotia circumborealis (33210) } \\
\hline \multicolumn{8}{|l|}{ Eunotia denticulata (33011) } \\
\hline \multicolumn{8}{|l|}{ Eunotia exigua (33015) } \\
\hline Eunotia faba (33172) & 1 & 3 & 2 & 2 & 6 & 2 & 6 \\
\hline \multicolumn{8}{|l|}{ Eunotia implicata (33168) } \\
\hline Eunotia incisa (33026) & & & & & 1 & & \\
\hline \multicolumn{8}{|l|}{ Eunotia minor (33183) } \\
\hline \multicolumn{8}{|l|}{ Eunotia monodon (33035) } \\
\hline \multicolumn{8}{|l|}{ Eunotia muscicola (33184) } \\
\hline \multicolumn{8}{|l|}{ Eunotia paludosa (33083) } \\
\hline \multicolumn{8}{|l|}{ Eunotia pectinalis (33039) } \\
\hline \multicolumn{8}{|l|}{ Eunotia praerupta (33045) } \\
\hline \multicolumn{8}{|l|}{ Eunotia rhomboidea (33051) } \\
\hline \multicolumn{8}{|l|}{ Eunotia rhynchocephala (33191) } \\
\hline Eunotia septentrionalis (33053) & 2 & & & & & & \\
\hline Eunotia serra (33054) & & & & & 2 & & \\
\hline Eunotia soleirolii (33056) & & 1 & & 1 & & & \\
\hline Fragilaria capucina (34006) & 1 & & 1 & 1 & & & \\
\hline \multicolumn{8}{|l|}{ Fragilaria delicatissima } \\
\hline Frustulia krammeri (35039) & 5 & & 5 & & 8 & 2 & \\
\hline Gomphonema acuminatum (37001) & & & & 1 & & & \\
\hline Gomphonema angustatum (37003) & 4 & 1 & & 1 & 1 & 1 & 1 \\
\hline
\end{tabular}




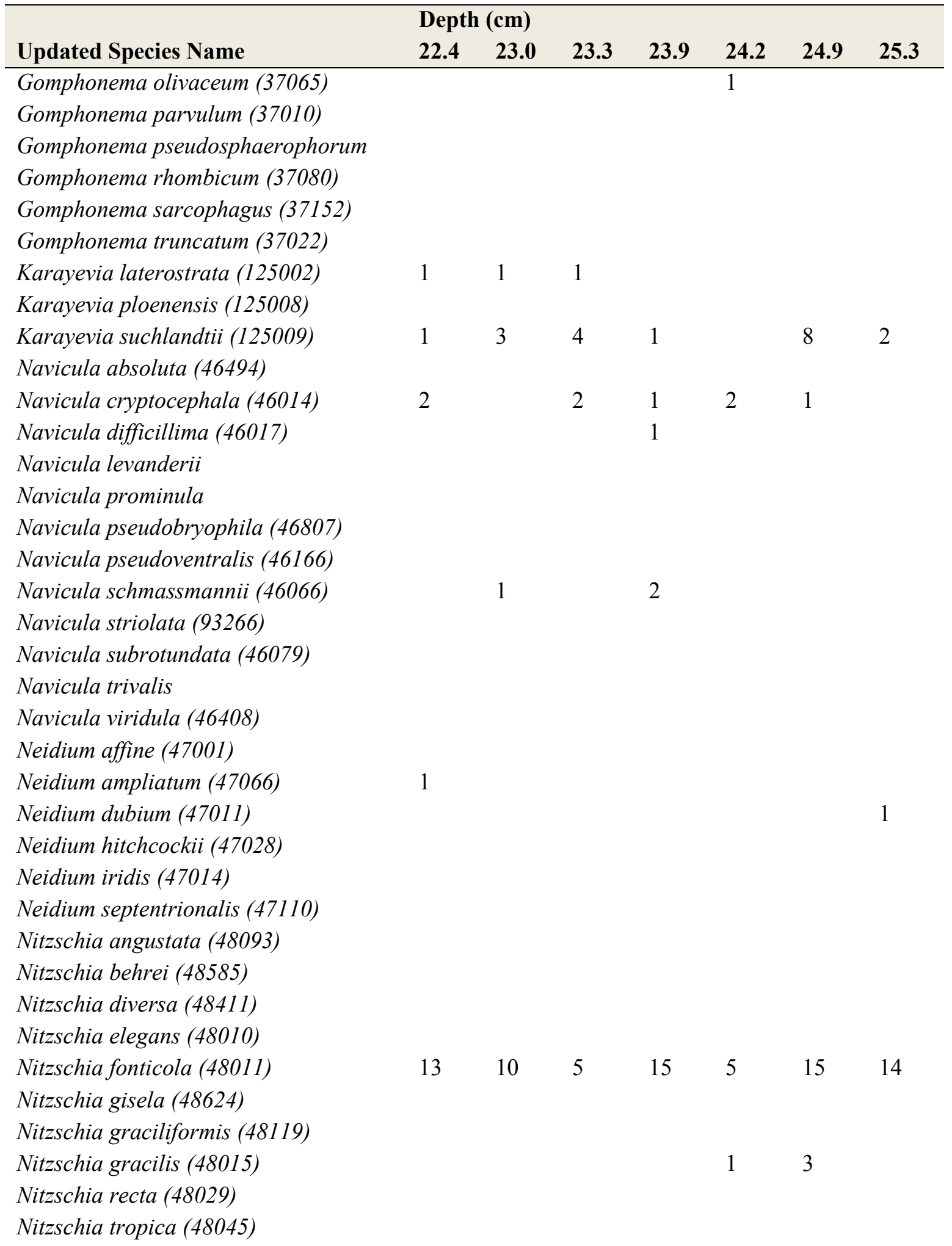




\begin{tabular}{|c|c|c|c|c|c|c|c|}
\hline \multirow[b]{2}{*}{ Updated Species Name } & \multicolumn{7}{|c|}{ Depth (cm) } \\
\hline & 22.4 & 23.0 & 23.3 & 23.9 & 24.2 & 24.9 & 25.3 \\
\hline \multicolumn{8}{|l|}{ Nupela gracillima (92026) } \\
\hline \multicolumn{8}{|l|}{ Oxyneis binalis (9107001) } \\
\hline Pinnularia alpina (52807) & & 1 & & & & & \\
\hline \multicolumn{8}{|l|}{ Pinnularia appendiculata (52009) } \\
\hline \multicolumn{8}{|l|}{ Pinnularia borealis (52013) } \\
\hline \multicolumn{8}{|l|}{ Pinnularia brauniana (103001) } \\
\hline \multicolumn{8}{|l|}{ Pinnularia divergens (52025) } \\
\hline \multicolumn{8}{|l|}{ Pinnularia episcopalis } \\
\hline \multicolumn{8}{|l|}{ Pinnularia gibba (52159) } \\
\hline Pinnularia interrupta (52194) & & & & & & & 2 \\
\hline \multicolumn{8}{|l|}{ Pinnularia karelica } \\
\hline Pinnularia microstauron (52045) & & & & & 1 & & \\
\hline \multicolumn{8}{|l|}{ Pinnularia nobilis (103038) } \\
\hline Pinnularia nodosa (52048) & & & & & & 1 & \\
\hline \multicolumn{8}{|l|}{ Pinnularia polyonca (52087) } \\
\hline \multicolumn{8}{|l|}{ Pinnularia polyonca (52087) } \\
\hline \multicolumn{8}{|l|}{ Pinnularia pulchra (52801) } \\
\hline Pinnularia subcapitata (52059) & 1 & & & & 1 & & 2 \\
\hline \multicolumn{8}{|l|}{ Pinnularia subrostrata (52184) } \\
\hline \multicolumn{8}{|l|}{ Pinnularia superdiverdentissima } \\
\hline Pinnularia viridis (52071) & & & & & 1 & 1 & \\
\hline \multicolumn{8}{|l|}{ Placoneis elginensis (194005) } \\
\hline \multicolumn{8}{|l|}{ Planothidium joursacense (155016) } \\
\hline \multicolumn{8}{|l|}{ Planothidium oestrupii (155026) } \\
\hline \multicolumn{8}{|l|}{ Platessa holsatica (2508002) } \\
\hline Psammothidium curtissimum (186021) & 1 & 3 & 2 & 15 & & & 1 \\
\hline Psammothidium didymum (186012) & 1 & & & & & & \\
\hline \multicolumn{8}{|l|}{ Psammothidium helveticum (186003) } \\
\hline \multicolumn{8}{|l|}{ Psammothidium ventralis (186009) } \\
\hline Pseudostaurosira brevistriata (73001) & 20 & 30 & 21 & 24 & 13 & 31 & 17 \\
\hline Pseudostaurosira elliptica (73025) & 3 & 5 & & 6 & 3 & 3 & \\
\hline Pseudostaurosira pseudoconstruens (73002) & 6 & 3 & 1 & 3 & 3 & 3 & 3 \\
\hline Puncticulata bodanica (208004) & 8 & 3 & 5 & 3 & 8 & 3 & 2 \\
\hline \multicolumn{8}{|l|}{ Reimeria sinuata (55002) } \\
\hline Rossithidium nodosum (189006) & & & 3 & 2 & 2 & & \\
\hline Rossithidium pusillum (189003) & 8 & 6 & 7 & 6 & 3 & 11 & 1 \\
\hline Sellaphora pupula (170006) & 4 & 1 & & 2 & 1 & 4 & 2 \\
\hline
\end{tabular}


Stauroneis acuta (62036)

Stauroneis anceps (62002)

Stauroneis cf. javanica (62045)

Stauroneis cf. schimanskii (62127)

Stauroneis phoenicenteron (62015)

Stauroneis producta (62017)

Stauroneis prominula (62069)

$\begin{array}{llllll}1 & 1 & & & & \\ 1 & & 1 & 1 & 3 & 1 \\ & & & & 1 & \end{array}$

Stauroneis thermicola (62040)

Staurosira construens (172001)

Staurosira construens var. binodis (172005)

\begin{tabular}{|c|c|c|c|c|c|c|}
\hline & & 1 & & 1 & & \\
\hline 6 & 3 & 11 & 2 & 11 & 1 & 7 \\
\hline 40 & 17 & 33 & 23 & 30 & 22 & 37 \\
\hline & 10 & 5 & 12 & 11 & 13 & \\
\hline
\end{tabular}

Staurosira construens var. exigua (172022)

Staurosirella lapponica (175002)

Staurosirella leptostauron var. rhomboides (175017) 5

Staurosirella pinnata (175005)

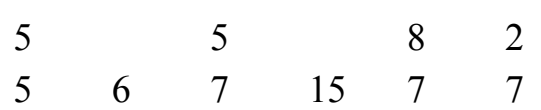

Stenopterobia anceps (63003)

Stenopterobia delicatissima (63007)

Surirella amphioxys (65069)

Surirella angusta (65002)

Surirella elegans (65072)

Surirella gracilis (65013)

Surirella linearis (65014)

Tabellaria fenestrata (67002)

Tabellaria flocculosa (67004)

Tabularia fasciculata (200002)

Tetracyclus glans (71006)

Tetracyclus lacustris (71003)

\begin{tabular}{llllllll}
\hline \hline Total chrysophyte cysts per slice & 36 & 41 & 80 & 55 & 45 & 60 & \\
Total diatom counts per slice & 467 & 411 & 431 & 501 & 467 & 456 & 410 \\
Total microspheres per slice & & 24 & & 97 & & 22 &
\end{tabular}




\begin{tabular}{|c|c|c|c|c|c|c|c|}
\hline \multirow[b]{2}{*}{ Updated Species Name } & \multicolumn{7}{|c|}{ Depth (cm) } \\
\hline & 25.7 & 26.3 & 26.7 & 27.3 & 27.8 & 28.2 & 28.6 \\
\hline \multicolumn{8}{|l|}{ Achnanthes imperfecta (2051) } \\
\hline Achnanthes levanderi (2022) & 2 & 10 & 1 & 9 & 8 & 8 & 5 \\
\hline \multicolumn{8}{|l|}{ Achnanthes pergalli } \\
\hline Achnanthes pseudoswazi (2206) & 1 & 1 & & 1 & & & \\
\hline \multicolumn{8}{|l|}{ Achnanthes trinodis (2109) } \\
\hline Achnanthidium minutissimum (1010) & 13 & 22 & 8 & 12 & 18 & 21 & 12 \\
\hline \multicolumn{8}{|l|}{ Achnanthidium semiapertum (1028) } \\
\hline \multicolumn{8}{|l|}{ Amphipleura lindheimerii } \\
\hline \multicolumn{8}{|l|}{ Amphora copulata (7075) } \\
\hline \multicolumn{8}{|l|}{ Amphora ovalis (7001) } \\
\hline Aulacoseira alpigena (10028) & 155 & 160 & 153 & 147 & 112 & 160 & 134 \\
\hline Aulacoseira ambigua (10008) & & & 2 & & & & \\
\hline Aulacoseira canadensis (10003) & & & & & & & 1 \\
\hline \multicolumn{8}{|l|}{ Aulacoseira crassipunctata (10001) } \\
\hline Aulacoseira distans (10009) & 10 & 13 & 32 & 4 & 8 & 16 & 8 \\
\hline \multicolumn{8}{|l|}{ Aulacoseira granulata (10018) } \\
\hline \multicolumn{8}{|l|}{ Aulacoseira italica (10019) } \\
\hline Aulacoseira lacustris (10060) & 13 & & 26 & & 24 & & 25 \\
\hline \multicolumn{8}{|l|}{ Aulacoseira lirata (10012) } \\
\hline \multicolumn{8}{|l|}{ Aulacoseira muzzanensis (10031) } \\
\hline Aulacoseira perglabra (10006) & 7 & & 11 & & 3 & & 8 \\
\hline Aulacoseira subarctica (10015) & & & 3 & & & & 2 \\
\hline Aulacoseira tethera (10033) & 4 & & & & 1 & & 1 \\
\hline \multicolumn{8}{|l|}{ Aulacoseira valida (10029) } \\
\hline \multicolumn{8}{|l|}{ Bacillaria paradoxa (76001) } \\
\hline Brachysira brebissonii (18005) & 10 & 4 & 13 & 5 & 3 & 2 & 8 \\
\hline Brachysira microcephala (18013) & & & & 1 & 1 & 2 & 3 \\
\hline Caloneis alpestris (12025) & & & 1 & & & & \\
\hline \multicolumn{8}{|l|}{ Caloneis lauta (12026) } \\
\hline \multicolumn{8}{|l|}{ Caloneis permagna (12030) } \\
\hline \multicolumn{8}{|l|}{ Caloneis silicula (12010) } \\
\hline Caloneis tenuis (12013) & & & 1 & & & & \\
\hline \multicolumn{8}{|l|}{ Caloneis thermalis (12054) } \\
\hline \multicolumn{8}{|l|}{ Caloneis undulata (12022) } \\
\hline \multicolumn{8}{|l|}{ Caloneis westii (12056) } \\
\hline Cavinula cocconeiformis (195001) & 1 & 3 & 3 & 3 & 2 & 1 & 2 \\
\hline Cavinula pseudoscutiformis (195003) & 2 & 2 & 1 & 7 & 4 & 3 & 2 \\
\hline
\end{tabular}




\begin{tabular}{|c|c|c|c|c|c|c|c|}
\hline \multirow[b]{2}{*}{ Updated Species Name } & \multicolumn{7}{|c|}{ Depth (cm) } \\
\hline & 25.7 & 26.3 & 26.7 & 27.3 & 27.8 & 28.2 & 28.6 \\
\hline Chamaepinnularia mediocris (212005) & & & & & & & 2 \\
\hline \multicolumn{8}{|l|}{ Chamaepinnularia soehrensis (212006) } \\
\hline \multicolumn{8}{|l|}{ Cocconeis placentula (16004) } \\
\hline Craticula halophila (21005) & & & 1 & & & & \\
\hline \multicolumn{8}{|l|}{ Craticula riparia (21016) } \\
\hline Cyclotella comensis (20023) & 2 & & 2 & & & & \\
\hline \multicolumn{8}{|l|}{ Cyclotella krammeri (20083) } \\
\hline Cyclotella ocellata (20009) & 29 & 23 & 36 & 40 & 30 & 36 & 43 \\
\hline Cyclotella rossii (20019) & 3 & 1 & 2 & 1 & & & \\
\hline Cyclotella tripartita (20085) & 4 & 3 & 11 & 6 & 4 & 8 & 3 \\
\hline \multicolumn{8}{|l|}{ Cymbella affinis (23073) } \\
\hline \multicolumn{8}{|l|}{ Cymbella amphicephala (23001) } \\
\hline \multicolumn{8}{|l|}{ Cymbella cesatii (23004) } \\
\hline \multicolumn{8}{|l|}{ Cymbella cistula (23005) } \\
\hline \multicolumn{8}{|l|}{ Cymbella helvetica (23099) } \\
\hline \multicolumn{8}{|l|}{ Cymbella heteropleura (23100) } \\
\hline \multicolumn{8}{|l|}{ Cymbella lapponica (23116) } \\
\hline \multicolumn{8}{|l|}{ Cymbella rupicola (23020) } \\
\hline \multicolumn{8}{|l|}{ Cymbella schimanskii } \\
\hline Cymbella sileiaca & 1 & 8 & 8 & 5 & 2 & 4 & 2 \\
\hline \multicolumn{8}{|l|}{ Cymbella tumidula (23082) } \\
\hline \multicolumn{8}{|l|}{ Cymbella tynnii (47141) } \\
\hline \multicolumn{8}{|l|}{ Cymbopleura angustata (190013) } \\
\hline \multicolumn{8}{|l|}{ Cymbopleura cuspidata (190001) } \\
\hline \multicolumn{8}{|l|}{ Cymbopleura subaequalis (190017) } \\
\hline \multicolumn{8}{|l|}{ Denticula elegans (25001) } \\
\hline Denticula keutzingii & & & & & 1 & & \\
\hline \multicolumn{8}{|l|}{ Diatoma mesodon (27002) } \\
\hline \multicolumn{8}{|l|}{ Diatoma vulgaris (27013) } \\
\hline \multicolumn{8}{|l|}{ Diploneis boldtiana (30012) } \\
\hline \multicolumn{8}{|l|}{ Diploneis elliptica (30001) } \\
\hline \multicolumn{8}{|l|}{ Diploneis finnica (30002) } \\
\hline Diploneis marginestriata (30003) & 1 & & 1 & & 1 & & 1 \\
\hline Diploneis ovalis (30009) & & & & & & & \\
\hline Diploneis parma (30014) & & & & & & & \\
\hline Discostella pseudostelligera (2506002) & 10 & 9 & 9 & 18 & 20 & 11 & 14 \\
\hline Discostella stelligera (2506003) & 1 & 7 & 4 & 2 & 2 & & 3 \\
\hline
\end{tabular}




\begin{tabular}{|c|c|c|c|c|c|c|c|}
\hline \multirow[b]{2}{*}{ Updated Species Name } & \multicolumn{7}{|c|}{ Depth (cm) } \\
\hline & 25.7 & 26.3 & 26.7 & 27.3 & 27.8 & 28.2 & 28.6 \\
\hline Encyonema elginense (110044) & 1 & & & & 1 & & \\
\hline Encyonema gaeumannii (110008) & 3 & & & & 5 & & \\
\hline \multicolumn{8}{|l|}{ Encyonema neogracile (110045) } \\
\hline Encyonopsis descripta (203014) & 1 & & & & & 1 & \\
\hline \multicolumn{8}{|l|}{ Encyonopsis falaisensis (203007) } \\
\hline \multicolumn{8}{|l|}{ Encyonopsis microcephala (203002) } \\
\hline Encyonopsis minuta (203011) & 1 & 3 & 2 & 1 & 1 & 3 & \\
\hline \multicolumn{8}{|l|}{ Epithemia adnata (32003) } \\
\hline Epithemia smithii (32002) & 1 & & & & & & \\
\hline Epithemia sorex (32006) & & & 1 & & & & \\
\hline Eucocconeis flexella (187001) & 1 & & & 1 & & & \\
\hline \multicolumn{8}{|l|}{ Eucocconeis laevis (187002) } \\
\hline Eunotia arcus (33001) & & & & & 1 & & \\
\hline Eunotia bigibba (33005) & & 1 & & & & & \\
\hline Eunotia bilunaris (33185) & & & 1 & & & & \\
\hline \multicolumn{8}{|l|}{ Eunotia circumborealis (33210) } \\
\hline \multicolumn{8}{|l|}{ Eunotia denticulata (33011) } \\
\hline \multicolumn{8}{|l|}{ Eunotia exigua (33015) } \\
\hline Eunotia faba (33172) & 2 & 6 & 12 & 1 & 1 & 1 & 4 \\
\hline \multicolumn{8}{|l|}{ Eunotia implicata (33168) } \\
\hline Eunotia incisa (33026) & & & 2 & & & & \\
\hline \multicolumn{8}{|l|}{ Eunotia minor (33183) } \\
\hline \multicolumn{8}{|l|}{ Eunotia monodon (33035) } \\
\hline \multicolumn{8}{|l|}{ Eunotia muscicola (33184) } \\
\hline \multicolumn{8}{|l|}{ Eunotia paludosa (33083) } \\
\hline \multicolumn{8}{|l|}{ Eunotia pectinalis (33039) } \\
\hline \multicolumn{8}{|l|}{ Eunotia praerupta (33045) } \\
\hline \multicolumn{8}{|l|}{ Eunotia rhomboidea (33051) } \\
\hline \multicolumn{8}{|l|}{ Eunotia rhynchocephala (33191) } \\
\hline Eunotia septentrionalis (33053) & & & 1 & & & & \\
\hline Eunotia serra (33054) & & & 1 & & 1 & & \\
\hline Eunotia soleirolii (33056) & & & 1 & & & & \\
\hline Fragilaria capucina (34006) & 2 & 2 & 3 & 1 & 1 & & \\
\hline \multicolumn{8}{|l|}{ Fragilaria delicatissima } \\
\hline Frustulia krammeri (35039) & 3 & 3 & 3 & & 1 & 1 & 3 \\
\hline Gomphonema acuminatum (37001) & & & & & & 1 & \\
\hline Gomphonema angustatum (37003) & 1 & & 1 & 1 & & & 2 \\
\hline
\end{tabular}




\begin{tabular}{|c|c|c|c|c|c|c|c|}
\hline \multirow[b]{2}{*}{ Updated Species Name } & \multicolumn{7}{|c|}{ Depth (cm) } \\
\hline & 25.7 & 26.3 & 26.7 & 27.3 & 27.8 & 28.2 & 28.6 \\
\hline \multicolumn{8}{|l|}{ Gomphonema olivaceum (37065) } \\
\hline \multicolumn{8}{|l|}{ Gomphonema parvulum (37010) } \\
\hline \multicolumn{8}{|l|}{ Gomphonema pseudosphaerophorum } \\
\hline \multicolumn{8}{|l|}{ Gomphonema rhombicum (37080) } \\
\hline Gomphonema sarcophagus (37152) & & & 1 & & & & 1 \\
\hline \multicolumn{8}{|l|}{ Gomphonema truncatum (37022) } \\
\hline Karayevia laterostrata (125002) & & 1 & & & & & \\
\hline \multicolumn{8}{|l|}{ Karayevia ploenensis (125008) } \\
\hline Karayevia suchlandtii (125009) & 2 & 1 & 1 & 3 & 5 & 3 & 5 \\
\hline \multicolumn{8}{|l|}{ Navicula absoluta (46494) } \\
\hline Navicula cryptocephala (46014) & & 3 & 1 & 1 & & 5 & 1 \\
\hline \multicolumn{8}{|l|}{ Navicula difficillima (46017) } \\
\hline \multicolumn{8}{|l|}{ Navicula levanderii } \\
\hline \multicolumn{8}{|l|}{ Navicula prominula } \\
\hline \multicolumn{8}{|l|}{ Navicula pseudobryophila (46807) } \\
\hline \multicolumn{8}{|l|}{ Navicula pseudoventralis (46166) } \\
\hline Navicula schmassmannii (46066) & & 2 & 1 & & 2 & & \\
\hline \multicolumn{8}{|l|}{ Navicula striolata (93266) } \\
\hline \multicolumn{8}{|l|}{ Navicula subrotundata (46079) } \\
\hline \multicolumn{8}{|l|}{ Navicula trivalis } \\
\hline \multicolumn{8}{|l|}{ Navicula viridula (46408) } \\
\hline \multicolumn{8}{|l|}{ Neidium affine (47001) } \\
\hline \multicolumn{8}{|l|}{ Neidium ampliatum (47066) } \\
\hline \multicolumn{8}{|l|}{ Neidium dubium (47011) } \\
\hline \multicolumn{8}{|l|}{ Neidium hitchcockii (47028) } \\
\hline Neidium iridis (47014) & & & & & & & 1 \\
\hline \multicolumn{8}{|l|}{ Neidium septentrionalis (47110) } \\
\hline \multicolumn{8}{|l|}{ Nitzschia angustata (48093) } \\
\hline \multicolumn{8}{|l|}{ Nitzschia behrei (48585) } \\
\hline \multicolumn{8}{|l|}{ Nitzschia diversa (48411) } \\
\hline Nitzschia elegans (48010) & & & & & & & \\
\hline Nitzschia fonticola (48011) & 7 & 10 & 10 & 6 & 7 & 10 & 9 \\
\hline Nitzschia gisela (48624) & & & & & & & \\
\hline Nitzschia graciliformis (48119) & & & & & & & \\
\hline Nitzschia gracilis (48015) & & & & & & & \\
\hline Nitzschia recta (48029) & & & & & & & \\
\hline Nitzschia tropica (48045) & & & & & & & \\
\hline
\end{tabular}




\begin{tabular}{|c|c|c|c|c|c|c|c|}
\hline \multirow[b]{2}{*}{ Updated Species Name } & \multicolumn{2}{|c|}{ Depth (cm) } & \multirow[b]{2}{*}{26.7} & \multirow[b]{2}{*}{27.3} & \multirow[b]{2}{*}{27.8} & \multirow[b]{2}{*}{28.2} & \multirow[b]{2}{*}{28.6} \\
\hline & 25.7 & 26.3 & & & & & \\
\hline \multicolumn{8}{|l|}{ Nupela gracillima (92026) } \\
\hline \multicolumn{8}{|l|}{ Oxyneis binalis (9107001) } \\
\hline \multicolumn{8}{|l|}{ Pinnularia alpina (52807) } \\
\hline \multicolumn{8}{|l|}{ Pinnularia appendiculata (52009) } \\
\hline \multicolumn{8}{|l|}{ Pinnularia borealis (52013) } \\
\hline \multicolumn{8}{|l|}{ Pinnularia brauniana (103001) } \\
\hline \multicolumn{8}{|l|}{ Pinnularia divergens (52025) } \\
\hline Pinnularia episcopalis & & & 1 & & & & \\
\hline \multicolumn{8}{|l|}{ Pinnularia gibba (52159) } \\
\hline \multicolumn{8}{|l|}{ Pinnularia interrupta (52194) } \\
\hline \multicolumn{8}{|l|}{ Pinnularia karelica } \\
\hline \multicolumn{8}{|l|}{ Pinnularia microstauron (52045) } \\
\hline \multicolumn{8}{|l|}{ Pinnularia nobilis (103038) } \\
\hline \multicolumn{8}{|l|}{ Pinnularia nodosa (52048) } \\
\hline \multicolumn{8}{|l|}{ Pinnularia polyonca (52087) } \\
\hline \multicolumn{8}{|l|}{ Pinnularia polyonca (52087) } \\
\hline \multicolumn{8}{|l|}{ Pinnularia pulchra (52801) } \\
\hline Pinnularia subcapitata (52059) & & 2 & 3 & 1 & 1 & 2 & 1 \\
\hline \multicolumn{8}{|l|}{ Pinnularia subrostrata (52184) } \\
\hline \multicolumn{8}{|l|}{ Pinnularia superdiverdentissima } \\
\hline Pinnularia viridis (52071) & 1 & 1 & 1 & 1 & & & \\
\hline \multicolumn{8}{|l|}{ Placoneis elginensis (194005) } \\
\hline Planothidium joursacense (155016) & & & & & & & \\
\hline Planothidium oestrupii (155026) & & & & & & & \\
\hline Platessa holsatica (2508002) & & & & & & & \\
\hline Psammothidium curtissimum (186021) & 3 & 2 & & 1 & 3 & 4 & 3 \\
\hline Psammothidium didymum (186012) & & & & & & & \\
\hline Psammothidium helveticum (186003) & & & & & & & \\
\hline Psammothidium ventralis (186009) & & & 1 & & & & \\
\hline Pseudostaurosira brevistriata (73001) & 21 & 47 & 24 & 38 & 35 & 30 & 26 \\
\hline Pseudostaurosira elliptica (73025) & 1 & & 2 & & 7 & & \\
\hline Pseudostaurosira pseudoconstruens (73002) & 8 & 8 & 7 & 10 & 7 & 3 & 11 \\
\hline Puncticulata bodanica (208004) & 2 & 3 & 5 & 2 & 5 & 2 & 4 \\
\hline Reimeria sinuata (55002) & & & & & & & \\
\hline Rossithidium nodosum (189006) & & & & & & & \\
\hline Rossithidium pusillum (189003) & 6 & 7 & & 9 & 8 & 7 & 6 \\
\hline Sellaphora pupula (170006) & 2 & 3 & 2 & 7 & 4 & 6 & 7 \\
\hline
\end{tabular}




\section{Depth (cm)}

Updated Species Name

$\begin{array}{lllllll}25.7 & 26.3 & 26.7 & 27.3 & 27.8 & 28.2 & 28.6\end{array}$

Stauroneis acuta (62036)

Stauroneis anceps (62002)

Stauroneis cf. javanica (62045)

Stauroneis cf. schimanskii (62127)

Stauroneis phoenicenteron (62015)

Stauroneis producta (62017)

$\begin{array}{lll}2 & 1 & 3\end{array}$

2

1

Stauroneis prominula (62069)

Stauroneis thermicola (62040)

Staurosira construens (172001)

Staurosira construens var. binodis (172005)

Staurosira construens var. exigua (172022)

$\begin{array}{lllllll}6 & 9 & 2 & & & 2 & \\ 46 & 28 & 33 & 42 & 40 & 38 & 39 \\ 8 & 24 & 13 & 38 & 16 & 37 & 10\end{array}$

Staurosira construens var. venter (172006)

Staurosirella lapponica (175002)

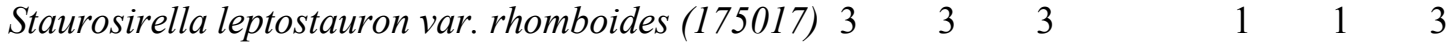

Staurosirella pinnata (175005)

$\begin{array}{lllllll}5 & 12 & 8 & 11 & 10 & 8\end{array}$

Stenopterobia anceps (63003)

Stenopterobia delicatissima (63007)

Surirella amphioxys (65069)

Surirella angusta (65002)

Surirella elegans (65072)

Surirella gracilis (65013)

Surirella linearis (65014)

Tabellaria fenestrata (67002)

Tabellaria flocculosa (67004)

Tabularia fasciculata (200002)

Tetracyclus glans (71006)

$\begin{array}{lllllll} & 3 & 3 & 1 & 1 & 4 & 1 \\ 7 & 4 & 5 & 5 & 9 & 6 & 5 \\ 1 & & 2 & & & & 1\end{array}$

Tetracyclus lacustris (71003)

\begin{tabular}{llllllll}
\hline \hline Total chrysophyte cysts per slice & 50 & & 34 & & 54 & & 26 \\
Total diatom counts per slice & 416 & 455 & 490 & 454 & 429 & 451 & 435 \\
Total microspheres per slice & & & & & 38 & &
\end{tabular}




\begin{tabular}{|c|c|c|c|c|c|c|c|}
\hline \multirow[b]{2}{*}{ Updated Species Name } & \multicolumn{7}{|c|}{ Depth (cm) } \\
\hline & 28.9 & 29.5 & 29.9 & 30.5 & 30.9 & 31.5 & 31.9 \\
\hline \multicolumn{8}{|l|}{ Achnanthes imperfecta (2051) } \\
\hline Achnanthes levanderi (2022) & 5 & & 6 & 5 & 8 & 3 & 1 \\
\hline \multicolumn{8}{|l|}{ Achnanthes pergalli } \\
\hline Achnanthes pseudoswazi (2206) & & & & & 1 & 3 & \\
\hline \multicolumn{8}{|l|}{ Achnanthes trinodis (2109) } \\
\hline Achnanthidium minutissimum (1010) & 18 & 11 & 17 & 36 & 9 & 6 & 19 \\
\hline \multicolumn{8}{|l|}{ Achnanthidium semiapertum (1028) } \\
\hline Amphipleura lindheimerii & & & & 1 & & & \\
\hline \multicolumn{8}{|l|}{ Amphora copulata (7075) } \\
\hline Amphora ovalis (7001) & & & & 1 & 1 & & 1 \\
\hline Aulacoseira alpigena (10028) & 179 & 152 & 162 & 120 & 157 & 121 & 173 \\
\hline \multicolumn{8}{|l|}{ Aulacoseira ambigua (10008) } \\
\hline Aulacoseira canadensis (10003) & 1 & & & & & & \\
\hline \multicolumn{8}{|l|}{ Aulacoseira crassipunctata (10001) } \\
\hline Aulacoseira distans (10009) & 26 & 20 & 7 & 22 & 7 & 16 & 28 \\
\hline \multicolumn{8}{|l|}{ Aulacoseira granulata (10018) } \\
\hline \multicolumn{8}{|l|}{ Aulacoseira italica (10019) } \\
\hline Aulacoseira lacustris (10060) & 1 & 31 & & 21 & 1 & 34 & 6 \\
\hline \multicolumn{8}{|l|}{ Aulacoseira lirata (10012) } \\
\hline \multicolumn{8}{|l|}{ Aulacoseira muzzanensis (10031) } \\
\hline Aulacoseira perglabra (10006) & & 3 & & 4 & & 6 & \\
\hline Aulacoseira subarctica (10015) & 1 & & 3 & 5 & 1 & 2 & \\
\hline Aulacoseira tethera (10033) & 1 & & & & 1 & 1 & 1 \\
\hline \multicolumn{8}{|l|}{ Aulacoseira valida (10029) } \\
\hline \multicolumn{8}{|l|}{ Bacillaria paradoxa (76001) } \\
\hline Brachysira brebissonii (18005) & 3 & 11 & 4 & 5 & 4 & 6 & 2 \\
\hline Brachysira microcephala (18013) & 2 & 1 & 1 & 1 & 2 & 1 & 1 \\
\hline \multicolumn{8}{|l|}{ Caloneis alpestris (12025) } \\
\hline \multicolumn{8}{|l|}{ Caloneis lauta (12026) } \\
\hline \multicolumn{8}{|l|}{ Caloneis permagna (12030) } \\
\hline \multicolumn{8}{|l|}{ Caloneis silicula (12010) } \\
\hline \multicolumn{8}{|l|}{ Caloneis tenuis (12013) } \\
\hline \multicolumn{8}{|l|}{ Caloneis thermalis (12054) } \\
\hline \multicolumn{8}{|l|}{ Caloneis undulata (12022) } \\
\hline \multicolumn{8}{|l|}{ Caloneis westii (12056) } \\
\hline Cavinula cocconeiformis (195001) & 1 & & & 1 & & 5 & 4 \\
\hline Cavinula pseudoscutiformis (195003) & 4 & 1 & 2 & 4 & 1 & 3 & 3 \\
\hline
\end{tabular}




\begin{tabular}{|c|c|c|c|c|c|c|c|}
\hline \multirow[b]{2}{*}{ Updated Species Name } & \multicolumn{7}{|c|}{ Depth (cm) } \\
\hline & 28.9 & 29.5 & 29.9 & 30.5 & 30.9 & 31.5 & 31.9 \\
\hline \multicolumn{8}{|l|}{ Chamaepinnularia mediocris (212005) } \\
\hline \multicolumn{8}{|l|}{ Chamaepinnularia soehrensis (212006) } \\
\hline Cocconeis placentula (16004) & 1 & & & & & & \\
\hline Craticula halophila (21005) & & & & & 1 & & \\
\hline \multicolumn{8}{|l|}{ Craticula riparia (21016) } \\
\hline Cyclotella comensis (20023) & 1 & & & & & 2 & \\
\hline \multicolumn{8}{|l|}{ Cyclotella krammeri (20083) } \\
\hline Cyclotella ocellata (20009) & 36 & 32 & 49 & 42 & 32 & 53 & 32 \\
\hline Cyclotella rossii (20019) & & 1 & 1 & & 2 & 2 & \\
\hline Cyclotella tripartita (20085) & 8 & 7 & 3 & 7 & 1 & 7 & 1 \\
\hline \multicolumn{8}{|l|}{ Cymbella affinis (23073) } \\
\hline \multicolumn{8}{|l|}{ Cymbella amphicephala (23001) } \\
\hline \multicolumn{8}{|l|}{ Cymbella cesatii (23004) } \\
\hline \multicolumn{8}{|l|}{ Cymbella cistula (23005) } \\
\hline \multicolumn{8}{|l|}{ Cymbella helvetica (23099) } \\
\hline \multicolumn{8}{|l|}{ Cymbella heteropleura (23100) } \\
\hline \multicolumn{8}{|l|}{ Cymbella lapponica (23116) } \\
\hline \multicolumn{8}{|l|}{ Cymbella rupicola (23020) } \\
\hline \multicolumn{8}{|l|}{ Cymbella schimanskii } \\
\hline Cymbella sileiaca & 2 & 7 & 4 & 3 & & 7 & 2 \\
\hline \multicolumn{8}{|l|}{ Cymbella tumidula (23082) } \\
\hline \multicolumn{8}{|l|}{ Cymbella tynnii (47141) } \\
\hline \multicolumn{8}{|l|}{ Cymbopleura angustata (190013) } \\
\hline \multicolumn{8}{|l|}{ Cymbopleura cuspidata (190001) } \\
\hline \multicolumn{8}{|l|}{ Cymbopleura subaequalis (190017) } \\
\hline \multicolumn{8}{|l|}{ Denticula elegans (25001) } \\
\hline \multicolumn{8}{|l|}{ Denticula keutzingii } \\
\hline \multicolumn{8}{|l|}{ Diatoma mesodon (27002) } \\
\hline \multicolumn{8}{|l|}{ Diatoma vulgaris (27013) } \\
\hline \multicolumn{8}{|l|}{ Diploneis boldtiana (30012) } \\
\hline \multicolumn{8}{|l|}{ Diploneis elliptica (30001) } \\
\hline Diploneis finnica (30002) & & & & & & & \\
\hline Diploneis marginestriata (30003) & 1 & & & 3 & 1 & 1 & 1 \\
\hline Diploneis ovalis (30009) & & & & & & 1 & \\
\hline Diploneis parma (30014) & & & & & & 1 & \\
\hline Discostella pseudostelligera (2506002) & 4 & 10 & 12 & 4 & 9 & 6 & 9 \\
\hline Discostella stelligera (2506003) & 2 & 1 & 1 & 5 & 2 & & 3 \\
\hline
\end{tabular}




\begin{tabular}{|c|c|c|c|c|c|c|c|}
\hline \multirow[b]{2}{*}{ Updated Species Name } & \multicolumn{7}{|c|}{ Depth (cm) } \\
\hline & 28.9 & 29.5 & 29.9 & 30.5 & 30.9 & 31.5 & 31.9 \\
\hline Encyonema elginense (110044) & 1 & 3 & & & & & \\
\hline Encyonema gaeumannii (110008) & & 3 & & 3 & & 3 & \\
\hline \multicolumn{8}{|l|}{ Encyonema neogracile (110045) } \\
\hline Encyonopsis descripta (203014) & 1 & & & & & 1 & 3 \\
\hline \multicolumn{8}{|l|}{ Encyonopsis falaisensis (203007) } \\
\hline \multicolumn{8}{|l|}{ Encyonopsis microcephala (203002) } \\
\hline Encyonopsis minuta (203011) & 1 & 1 & 4 & 1 & 3 & 2 & 4 \\
\hline \multicolumn{8}{|l|}{ Epithemia adnata (32003) } \\
\hline Epithemia smithii (32002) & & & & 1 & & 2 & \\
\hline Epithemia sorex (32006) & & 1 & & & & & \\
\hline Eucocconeis flexella (187001) & & 1 & & & & & \\
\hline \multicolumn{8}{|l|}{ Eucocconeis laevis (187002) } \\
\hline Eunotia arcus (33001) & 1 & 1 & 1 & & & & \\
\hline \multicolumn{8}{|l|}{ Eunotia bigibba (33005) } \\
\hline Eunotia bilunaris (33185) & & 2 & & & & 1 & 1 \\
\hline \multicolumn{8}{|l|}{ Eunotia circumborealis (33210) } \\
\hline \multicolumn{8}{|l|}{ Eunotia denticulata (33011) } \\
\hline \multicolumn{8}{|l|}{ Eunotia exigua (33015) } \\
\hline Eunotia faba (33172) & 3 & 4 & 4 & 2 & 5 & 7 & 7 \\
\hline \multicolumn{8}{|l|}{ Eunotia implicata (33168) } \\
\hline \multicolumn{8}{|l|}{ Eunotia incisa (33026) } \\
\hline \multicolumn{8}{|l|}{ Eunotia minor (33183) } \\
\hline \multicolumn{8}{|l|}{ Eunotia monodon (33035) } \\
\hline \multicolumn{8}{|l|}{ Eunotia muscicola (33184) } \\
\hline \multicolumn{8}{|l|}{ Eunotia paludosa (33083) } \\
\hline \multicolumn{8}{|l|}{ Eunotia pectinalis (33039) } \\
\hline \multicolumn{8}{|l|}{ Eunotia praerupta (33045) } \\
\hline \multicolumn{8}{|l|}{ Eunotia rhomboidea (33051) } \\
\hline \multicolumn{8}{|l|}{ Eunotia rhynchocephala (33191) } \\
\hline \multicolumn{8}{|l|}{ Eunotia septentrionalis (33053) } \\
\hline Eunotia serra (33054) & & 2 & 1 & 2 & & 1 & \\
\hline Eunotia soleirolii (33056) & & 1 & & & & & \\
\hline Fragilaria capucina (34006) & 1 & 2 & 2 & 1 & 1 & 1 & \\
\hline \multicolumn{8}{|l|}{ Fragilaria delicatissima } \\
\hline Frustulia krammeri (35039) & & 5 & 1 & 2 & & 2 & 1 \\
\hline Gomphonema acuminatum (37001) & & & & & & 1 & \\
\hline Gomphonema angustatum (37003) & 1 & 1 & & & 3 & 2 & 1 \\
\hline
\end{tabular}




\begin{tabular}{|c|c|c|c|c|c|c|c|}
\hline \multirow[b]{2}{*}{ Updated Species Name } & \multicolumn{7}{|c|}{ Depth (cm) } \\
\hline & 28.9 & 29.5 & 29.9 & 30.5 & 30.9 & 31.5 & 31.9 \\
\hline \multicolumn{8}{|l|}{ Gomphonema olivaceum (37065) } \\
\hline \multicolumn{8}{|l|}{ Gomphonema parvulum (37010) } \\
\hline \multicolumn{8}{|l|}{ Gomphonema pseudosphaerophorum } \\
\hline \multicolumn{8}{|l|}{ Gomphonema rhombicum (37080) } \\
\hline Gomphonema sarcophagus (37152) & & & & 1 & & & \\
\hline \multicolumn{8}{|l|}{ Gomphonema truncatum (37022) } \\
\hline Karayevia laterostrata (125002) & 1 & & & 1 & & & \\
\hline \multicolumn{8}{|l|}{ Karayevia ploenensis (125008) } \\
\hline Karayevia suchlandtii (125009) & 2 & & 2 & 5 & 1 & 1 & 6 \\
\hline \multicolumn{8}{|l|}{ Navicula absoluta (46494) } \\
\hline Navicula cryptocephala (46014) & 1 & & 2 & 4 & & 1 & 2 \\
\hline \multicolumn{8}{|l|}{ Navicula difficillima (46017) } \\
\hline \multicolumn{8}{|l|}{ Navicula levanderii } \\
\hline \multicolumn{8}{|l|}{ Navicula prominula } \\
\hline \multicolumn{8}{|l|}{ Navicula pseudobryophila (46807) } \\
\hline \multicolumn{8}{|l|}{ Navicula pseudoventralis (46166) } \\
\hline Navicula schmassmannii (46066) & & & & 1 & & & \\
\hline \multicolumn{8}{|l|}{ Navicula striolata (93266) } \\
\hline \multicolumn{8}{|l|}{ Navicula subrotundata (46079) } \\
\hline \multicolumn{8}{|l|}{ Navicula trivalis } \\
\hline \multicolumn{8}{|l|}{ Navicula viridula (46408) } \\
\hline \multicolumn{8}{|l|}{ Neidium affine (47001) } \\
\hline \multicolumn{8}{|l|}{ Neidium ampliatum (47066) } \\
\hline Neidium dubium (47011) & 1 & & & & 1 & & 1 \\
\hline \multicolumn{8}{|l|}{ Neidium hitchcockii (47028) } \\
\hline \multicolumn{8}{|l|}{ Neidium iridis (47014) } \\
\hline \multicolumn{8}{|l|}{ Neidium septentrionalis (47110) } \\
\hline \multicolumn{8}{|l|}{ Nitzschia angustata (48093) } \\
\hline \multicolumn{8}{|l|}{ Nitzschia behrei (48585) } \\
\hline \multicolumn{8}{|l|}{ Nitzschia diversa (48411) } \\
\hline Nitzschia elegans (48010) & & & & & & & \\
\hline Nitzschia fonticola (48011) & 9 & 3 & 13 & 16 & 10 & 12 & 9 \\
\hline Nitzschia gisela (48624) & & & & & & & \\
\hline Nitzschia graciliformis (48119) & & & & & & & \\
\hline Nitzschia gracilis (48015) & & & & & & & \\
\hline Nitzschia recta (48029) & & & & & & & \\
\hline Nitzschia tropica (48045) & & & & & & & \\
\hline
\end{tabular}




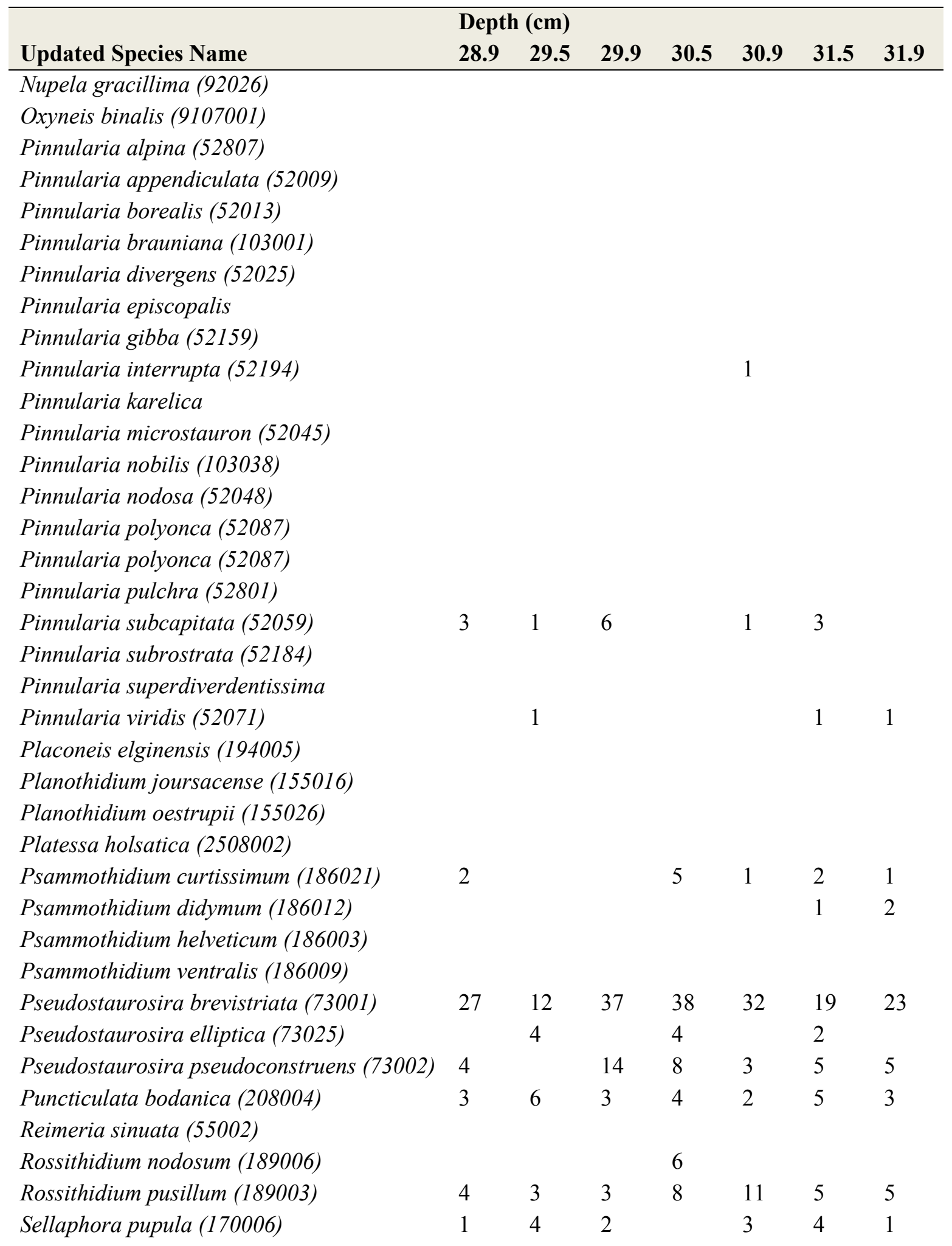




\begin{tabular}{|c|c|c|c|c|c|c|c|}
\hline \multirow[b]{2}{*}{ Updated Species Name } & \multicolumn{7}{|c|}{ Depth (cm) } \\
\hline & 28.9 & 29.5 & 29.9 & 30.5 & 30.9 & 31.5 & 31.9 \\
\hline \multicolumn{8}{|l|}{ Stauroneis acuta (62036) } \\
\hline \multicolumn{8}{|l|}{ Stauroneis anceps (62002) } \\
\hline \multicolumn{8}{|l|}{ Stauroneis cf. javanica (62045) } \\
\hline \multicolumn{8}{|l|}{ Stauroneis cf. schimanskii (62127) } \\
\hline Stauroneis phoenicenteron (62015) & 1 & & & & & & \\
\hline Stauroneis producta (62017) & 1 & 3 & 2 & & & 2 & \\
\hline \multicolumn{8}{|l|}{ Stauroneis prominula (62069) } \\
\hline \multicolumn{8}{|l|}{ Stauroneis thermicola (62040) } \\
\hline Staurosira construens (172001) & & & & 3 & & & \\
\hline Staurosira construens var. binodis (172005) & 7 & 12 & 2 & 3 & 4 & 7 & 5 \\
\hline Staurosira construens var. exigua (172022) & 21 & 32 & 34 & 25 & 37 & 40 & 23 \\
\hline Staurosira construens var. venter (172006) & 22 & 5 & 26 & 17 & 33 & 9 & 23 \\
\hline \multicolumn{8}{|l|}{ Staurosirella lapponica (175002) } \\
\hline $\begin{array}{l}\text { Staurosirella leptostauron var. rhomboides } \\
\text { (175017) }\end{array}$ & & 5 & 1 & 2 & & 2 & 1 \\
\hline Staurosirella pinnata (175005) & 1 & 2 & 9 & 7 & 11 & 4 & 2 \\
\hline \multicolumn{8}{|l|}{ Stenopterobia anceps (63003) } \\
\hline \multicolumn{8}{|l|}{ Stenopterobia delicatissima (63007) } \\
\hline \multicolumn{8}{|l|}{ Surirella amphioxys (65069) } \\
\hline \multicolumn{8}{|l|}{ Surirella angusta (65002) } \\
\hline \multicolumn{8}{|l|}{ Surirella elegans (65072) } \\
\hline \multicolumn{8}{|l|}{ Surirella gracilis (65013) } \\
\hline Surirella linearis (65014) & & & 1 & & 1 & 1 & \\
\hline Tabellaria fenestrata (67002) & 1 & 1 & 3 & 2 & 3 & 1 & 3 \\
\hline Tabellaria flocculosa (67004) & 5 & 3 & 3 & 8 & 4 & 4 & 6 \\
\hline \multicolumn{8}{|l|}{ Tabularia fasciculata (200002) } \\
\hline Tetracyclus glans (71006) & & 1 & & 1 & & & \\
\hline \multicolumn{8}{|l|}{ Tetracyclus lacustris (71003) } \\
\hline Total chrysophyte cysts per slice & & 49 & & 51 & & 40 & \\
\hline Total diatom counts per slice & 423 & 413 & 448 & 471 & 412 & 441 & 426 \\
\hline Total microspheres per slice & & & & 26 & & & \\
\hline
\end{tabular}




\begin{tabular}{|c|c|c|c|c|c|c|c|}
\hline \multirow[b]{2}{*}{ Updated Species Name } & \multicolumn{7}{|c|}{ Depth (cm) } \\
\hline & 32.6 & 33.3 & 33.7 & 33.8 & 34.6 & 34.8 & 35.5 \\
\hline \multicolumn{8}{|l|}{ Achnanthes imperfecta (2051) } \\
\hline Achnanthes levanderi (2022) & 4 & 8 & 10 & 6 & 9 & 4 & 3 \\
\hline Achnanthes pergalli & & & & & & & 2 \\
\hline Achnanthes pseudoswazi (2206) & & & 1 & & & & \\
\hline \multicolumn{8}{|l|}{ Achnanthes trinodis (2109) } \\
\hline Achnanthidium minutissimum (1010) & 16 & 37 & 55 & 14 & 56 & 17 & 34 \\
\hline \multicolumn{8}{|l|}{ Achnanthidium semiapertum (1028) } \\
\hline Amphipleura lindheimerii & 1 & & & & & & \\
\hline \multicolumn{8}{|l|}{ Amphora copulata (7075) } \\
\hline Amphora ovalis (7001) & & & & 1 & & 1 & \\
\hline Aulacoseira alpigena (10028) & 149 & 79 & 99 & 159 & 92 & 174 & 98 \\
\hline Aulacoseira ambigua (10008) & & 5 & & & & & \\
\hline \multicolumn{8}{|l|}{ Aulacoseira canadensis (10003) } \\
\hline \multicolumn{8}{|l|}{ Aulacoseira crassipunctata (10001) } \\
\hline Aulacoseira distans (10009) & 38 & 21 & 24 & 13 & 30 & 10 & 35 \\
\hline Aulacoseira granulata (10018) & & 6 & & & & & \\
\hline \multicolumn{8}{|l|}{ Aulacoseira italica (10019) } \\
\hline Aulacoseira lacustris (10060) & 27 & 20 & 14 & 6 & 17 & & 14 \\
\hline Aulacoseira lirata (10012) & & 2 & & & & & \\
\hline Aulacoseira muzzanensis (10031) & & 4 & & & & & \\
\hline Aulacoseira perglabra (10006) & 9 & 4 & 8 & & 4 & & 4 \\
\hline Aulacoseira subarctica (10015) & 5 & 9 & 1 & 3 & & 3 & 2 \\
\hline Aulacoseira tethera (10033) & 2 & & 2 & 3 & & & \\
\hline \multicolumn{8}{|l|}{ Aulacoseira valida (10029) } \\
\hline \multicolumn{8}{|l|}{ Bacillaria paradoxa (76001) } \\
\hline Brachysira brebissonii (18005) & 6 & 10 & 10 & 5 & 7 & 1 & 7 \\
\hline Brachysira microcephala (18013) & 1 & 2 & 3 & & 2 & 3 & 1 \\
\hline \multicolumn{8}{|l|}{ Caloneis alpestris (12025) } \\
\hline \multicolumn{8}{|l|}{ Caloneis lauta (12026) } \\
\hline \multicolumn{8}{|l|}{ Caloneis permagna (12030) } \\
\hline \multicolumn{8}{|l|}{ Caloneis silicula (12010) } \\
\hline \multicolumn{8}{|l|}{ Caloneis tenuis (12013) } \\
\hline \multicolumn{8}{|l|}{ Caloneis thermalis (12054) } \\
\hline \multicolumn{8}{|l|}{ Caloneis undulata (12022) } \\
\hline \multicolumn{8}{|l|}{ Caloneis westii (12056) } \\
\hline Cavinula cocconeiformis (195001) & 1 & 4 & 2 & 2 & 3 & 3 & 5 \\
\hline Cavinula pseudoscutiformis (195003) & 6 & 2 & 4 & 4 & 3 & 4 & 6 \\
\hline
\end{tabular}




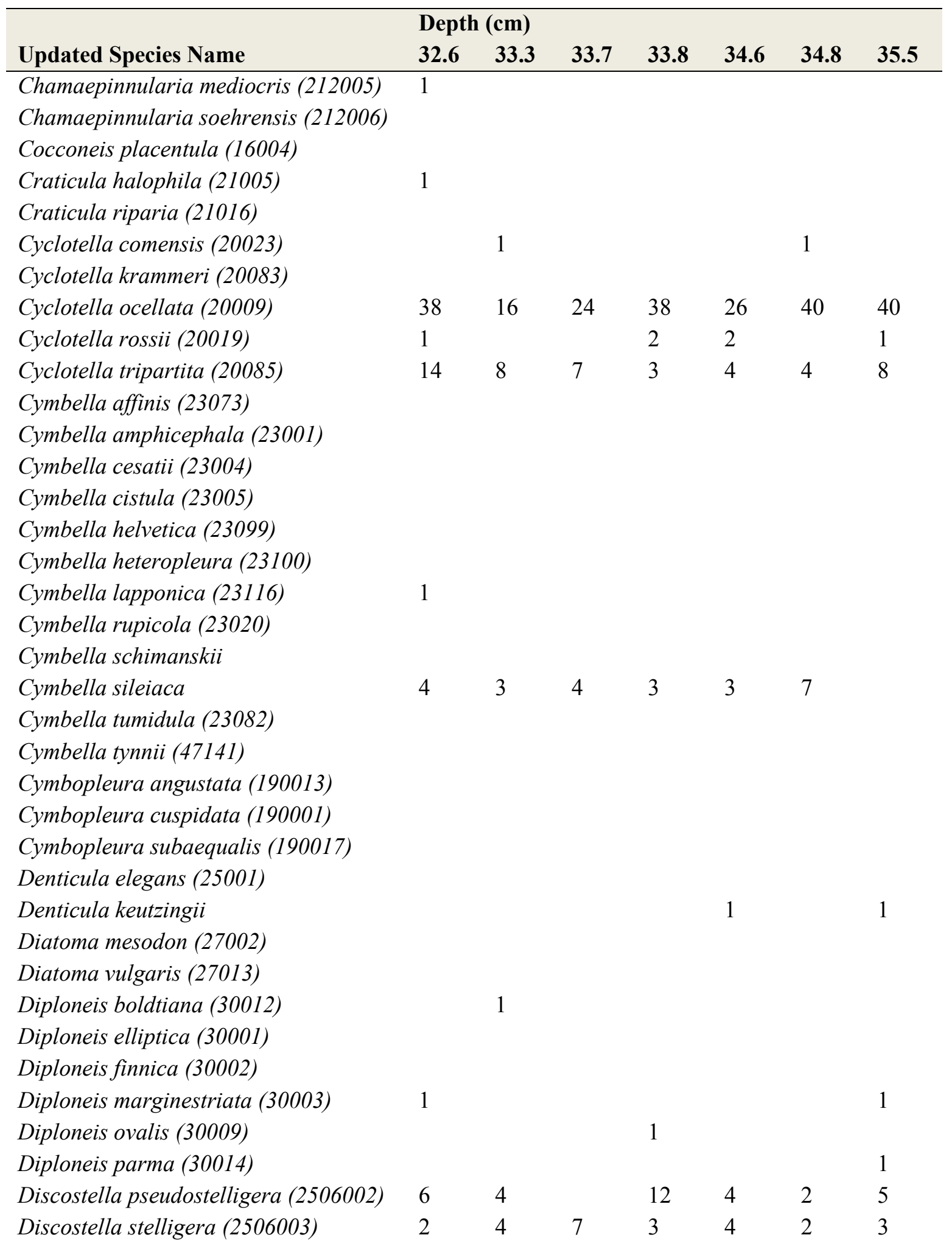




\begin{tabular}{|c|c|c|c|c|c|c|c|}
\hline \multirow[b]{2}{*}{ Updated Species Name } & \multicolumn{7}{|c|}{ Depth (cm) } \\
\hline & 32.6 & 33.3 & 33.7 & 33.8 & 34.6 & 34.8 & 35.5 \\
\hline Encyonema elginense (110044) & & & & & & & 1 \\
\hline Encyonema gaeumannii (110008) & 2 & 1 & 2 & & 2 & & 4 \\
\hline \multicolumn{8}{|l|}{ Encyonema neogracile (110045) } \\
\hline Encyonopsis descripta (203014) & 2 & & & 1 & 1 & & \\
\hline \multicolumn{8}{|l|}{ Encyonopsis falaisensis (203007) } \\
\hline \multicolumn{8}{|l|}{ Encyonopsis microcephala (203002) } \\
\hline Encyonopsis minuta (203011) & 2 & & & 6 & 1 & 3 & \\
\hline \multicolumn{8}{|l|}{ Epithemia adnata (32003) } \\
\hline Epithemia smithii (32002) & 1 & & & 1 & & & 1 \\
\hline Epithemia sorex (32006) & 1 & & & & & & \\
\hline Eucocconeis flexella (187001) & & & & & & & 1 \\
\hline Eucocconeis laevis (187002) & & 1 & & & & & \\
\hline Eunotia arcus (33001) & 1 & & 1 & 1 & 1 & & \\
\hline \multicolumn{8}{|l|}{ Eunotia bigibba (33005) } \\
\hline Eunotia bilunaris (33185) & 1 & & & & & & \\
\hline \multicolumn{8}{|l|}{ Eunotia circumborealis (33210) } \\
\hline \multicolumn{8}{|l|}{ Eunotia denticulata (33011) } \\
\hline Eunotia exigua (33015) & & & 1 & & & & \\
\hline Eunotia faba (33172) & 4 & 1 & 1 & 4 & 2 & 1 & \\
\hline \multicolumn{8}{|l|}{ Eunotia implicata (33168) } \\
\hline \multicolumn{8}{|l|}{ Eunotia incisa (33026) } \\
\hline \multicolumn{8}{|l|}{ Eunotia minor (33183) } \\
\hline \multicolumn{8}{|l|}{ Eunotia monodon (33035) } \\
\hline \multicolumn{8}{|l|}{ Eunotia muscicola (33184) } \\
\hline \multicolumn{8}{|l|}{ Eunotia paludosa (33083) } \\
\hline \multicolumn{8}{|l|}{ Eunotia pectinalis (33039) } \\
\hline \multicolumn{8}{|l|}{ Eunotia praerupta (33045) } \\
\hline \multicolumn{8}{|l|}{ Eunotia rhomboidea (33051) } \\
\hline Eunotia rhynchocephala (33191) & & 1 & & & & & \\
\hline \multicolumn{8}{|l|}{ Eunotia septentrionalis (33053) } \\
\hline Eunotia serra (33054) & & & & 1 & & & 2 \\
\hline Eunotia soleirolii (33056) & & & & & & & 2 \\
\hline Fragilaria capucina (34006) & & 2 & 2 & & 2 & 1 & 1 \\
\hline \multicolumn{8}{|l|}{ Fragilaria delicatissima } \\
\hline Frustulia krammeri (35039) & 5 & 2 & 1 & 2 & 2 & 2 & \\
\hline Gomphonema acuminatum (37001) & 1 & & & & & 1 & \\
\hline Gomphonema angustatum (37003) & & & 1 & & 2 & & 1 \\
\hline
\end{tabular}




\begin{tabular}{|c|c|c|c|c|c|c|c|}
\hline \multirow[b]{2}{*}{ Updated Species Name } & \multicolumn{7}{|c|}{ Depth (cm) } \\
\hline & 32.6 & 33.3 & 33.7 & 33.8 & 34.6 & 34.8 & 35.5 \\
\hline \multicolumn{8}{|l|}{ Gomphonema olivaceum (37065) } \\
\hline \multicolumn{8}{|l|}{ Gomphonema parvulum (37010) } \\
\hline \multicolumn{8}{|l|}{ Gomphonema pseudosphaerophorum } \\
\hline \multicolumn{8}{|l|}{ Gomphonema rhombicum (37080) } \\
\hline \multicolumn{8}{|l|}{ Gomphonema sarcophagus (37152) } \\
\hline \multicolumn{8}{|l|}{ Gomphonema truncatum (37022) } \\
\hline Karayevia laterostrata (125002) & 1 & & 4 & & & & \\
\hline \multicolumn{8}{|l|}{ Karayevia ploenensis (125008) } \\
\hline Karayevia suchlandtii (125009) & & 5 & 5 & & 4 & 3 & \\
\hline \multicolumn{8}{|l|}{ Navicula absoluta (46494) } \\
\hline Navicula cryptocephala (46014) & & & & & 1 & 1 & 2 \\
\hline \multicolumn{8}{|l|}{ Navicula difficillima (46017) } \\
\hline \multicolumn{8}{|l|}{ Navicula levanderii } \\
\hline \multicolumn{8}{|l|}{ Navicula prominula } \\
\hline \multicolumn{8}{|l|}{ Navicula pseudobryophila (46807) } \\
\hline \multicolumn{8}{|l|}{ Navicula pseudoventralis (46166) } \\
\hline Navicula schmassmannii (46066) & 1 & 2 & & & & & \\
\hline \multicolumn{8}{|l|}{ Navicula striolata (93266) } \\
\hline \multicolumn{8}{|l|}{ Navicula subrotundata (46079) } \\
\hline \multicolumn{8}{|l|}{ Navicula trivalis } \\
\hline \multicolumn{8}{|l|}{ Navicula viridula (46408) } \\
\hline \multicolumn{8}{|l|}{ Neidium affine (47001) } \\
\hline \multicolumn{8}{|l|}{ Neidium ampliatum (47066) } \\
\hline \multicolumn{8}{|l|}{ Neidium dubium (47011) } \\
\hline \multicolumn{8}{|l|}{ Neidium hitchcockii (47028) } \\
\hline \multicolumn{8}{|l|}{ Neidium iridis (47014) } \\
\hline \multicolumn{8}{|l|}{ Neidium septentrionalis (47110) } \\
\hline \multicolumn{8}{|l|}{ Nitzschia angustata (48093) } \\
\hline Nitzschia behrei (48585) & & & & & & & \\
\hline Nitzschia diversa (48411) & & & & & & & \\
\hline Nitzschia elegans (48010) & & & & & & & \\
\hline Nitzschia fonticola (48011) & 9 & 7 & 16 & 11 & 11 & 7 & 8 \\
\hline Nitzschia gisela (48624) & & & & & & & \\
\hline Nitzschia graciliformis (48119) & & & & & & & \\
\hline Nitzschia gracilis (48015) & & & & & & & \\
\hline Nitzschia recta (48029) & & & & & & & \\
\hline Nitzschia tropica (48045) & & & & & & & \\
\hline
\end{tabular}




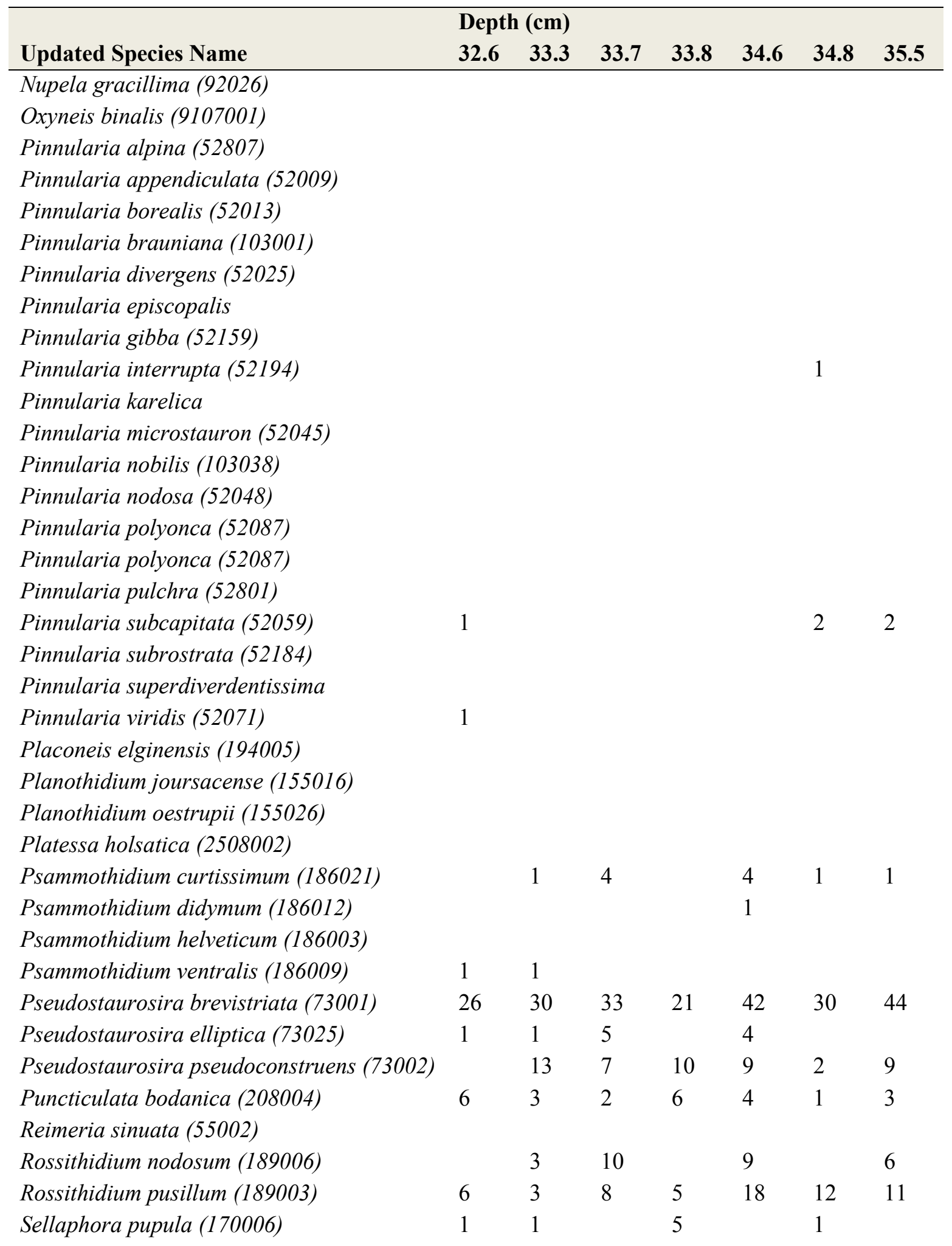




\section{Depth (cm)}

Updated Species Name

$\begin{array}{lllllll}32.6 & 33.3 & 33.7 & 33.8 & 34.6 & 34.8 & 35.5\end{array}$

Stauroneis acuta (62036)

Stauroneis anceps (62002)

Stauroneis cf. javanica (62045)

Stauroneis cf. schimanskii (62127)

Stauroneis phoenicenteron (62015)

Stauroneis producta (62017)

Stauroneis prominula (62069)

Stauroneis thermicola (62040)

Staurosira construens (172001)

Staurosira construens var. binodis (172005)

Staurosira construens var. exigua (172022)

Staurosira construens var. venter (172006)

Staurosirella lapponica (175002)

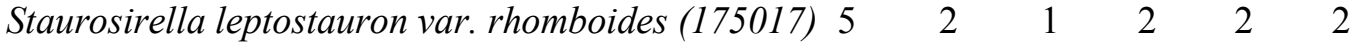

Staurosirella pinnata (175005)

$\begin{array}{lllllll}7 & 12 & 20 & 5 & 6 & 6 & 13\end{array}$

Stenopterobia anceps (63003)

Stenopterobia delicatissima (63007)

Surirella amphioxys (65069)

Surirella angusta (65002)

Surirella elegans (65072)

Surirella gracilis (65013)

Surirella linearis (65014)

Tabellaria fenestrata (67002)

Tabellaria flocculosa (67004)

$\begin{array}{lllllll}1 & 2 & & 1 & 2 & 1 & 5 \\ 5 & 2 & 8 & 3 & 9 & & 11\end{array}$

Tabularia fasciculata (200002)

Tetracyclus glans (71006)

Tetracyclus lacustris (71003)

\begin{tabular}{|c|c|c|c|c|c|c|c|}
\hline Total chrysophyte cysts per slice & 25 & 53 & 69 & & 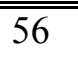 & & 59 \\
\hline Total diatom counts per slice & 475 & 435 & 477 & 435 & 475 & 403 & 452 \\
\hline Total microspheres per slice & & 42 & 86 & & 55 & & 67 \\
\hline
\end{tabular}




\begin{tabular}{|c|c|c|c|c|c|c|c|}
\hline \multirow[b]{2}{*}{ Updated Species Name } & \multicolumn{7}{|c|}{ Depth (cm) } \\
\hline & 35.6 & 36.3 & 36.8 & 37.2 & 37.7 & 38.0 & 38.4 \\
\hline \multicolumn{8}{|l|}{ Achnanthes imperfecta (2051) } \\
\hline Achnanthes levanderi (2022) & 9 & 16 & & 4 & 15 & 13 & 6 \\
\hline \multicolumn{8}{|l|}{ Achnanthes pergalli } \\
\hline Achnanthes pseudoswazi (2206) & & 1 & & 1 & 2 & & \\
\hline \multicolumn{8}{|l|}{ Achnanthes trinodis (2109) } \\
\hline Achnanthidium minutissimum (1010) & 24 & 58 & 16 & 31 & 31 & 43 & 11 \\
\hline \multicolumn{8}{|l|}{ Achnanthidium semiapertum (1028) } \\
\hline \multicolumn{8}{|l|}{ Amphipleura lindheimerii } \\
\hline \multicolumn{8}{|l|}{ Amphora copulata (7075) } \\
\hline \multicolumn{8}{|l|}{ Amphora ovalis (7001) } \\
\hline Aulacoseira alpigena (10028) & 141 & 107 & 207 & 102 & 136 & 87 & 194 \\
\hline Aulacoseira ambigua (10008) & & 2 & & & & & \\
\hline \multicolumn{8}{|l|}{ Aulacoseira canadensis (10003) } \\
\hline \multicolumn{8}{|l|}{ Aulacoseira crassipunctata (10001) } \\
\hline Aulacoseira distans (10009) & 22 & 42 & 8 & 16 & 12 & 40 & 22 \\
\hline Aulacoseira granulata (10018) & & & 4 & & & & \\
\hline \multicolumn{8}{|l|}{ Aulacoseira italica (10019) } \\
\hline Aulacoseira lacustris (10060) & & 27 & 21 & 14 & 1 & 13 & 9 \\
\hline \multicolumn{8}{|l|}{ Aulacoseira lirata (10012) } \\
\hline \multicolumn{8}{|l|}{ Aulacoseira muzzanensis (10031) } \\
\hline Aulacoseira perglabra (10006) & & 19 & & 19 & & 7 & \\
\hline Aulacoseira subarctica (10015) & 1 & & 2 & 4 & 4 & 4 & 10 \\
\hline Aulacoseira tethera (10033) & 1 & & & 1 & & & \\
\hline \multicolumn{8}{|l|}{ Aulacoseira valida (10029) } \\
\hline \multicolumn{8}{|l|}{ Bacillaria paradoxa (76001) } \\
\hline Brachysira brebissonii (18005) & 6 & 3 & 5 & 9 & 7 & 13 & 1 \\
\hline Brachysira microcephala (18013) & 1 & 1 & 2 & 3 & & & \\
\hline \multicolumn{8}{|l|}{ Caloneis alpestris (12025) } \\
\hline \multicolumn{8}{|l|}{ Caloneis lauta (12026) } \\
\hline \multicolumn{8}{|l|}{ Caloneis permagna (12030) } \\
\hline \multicolumn{8}{|l|}{ Caloneis silicula (12010) } \\
\hline \multicolumn{8}{|l|}{ Caloneis tenuis (12013) } \\
\hline \multicolumn{8}{|l|}{ Caloneis thermalis (12054) } \\
\hline \multicolumn{8}{|l|}{ Caloneis undulata (12022) } \\
\hline \multicolumn{8}{|l|}{ Caloneis westii (12056) } \\
\hline Cavinula cocconeiformis (195001) & 1 & 2 & & 5 & 2 & 2 & 4 \\
\hline Cavinula pseudoscutiformis (195003) & 1 & 2 & 1 & 7 & 3 & 1 & 3 \\
\hline
\end{tabular}




\begin{tabular}{|c|c|c|c|c|c|c|c|}
\hline \multirow[b]{2}{*}{ Updated Species Name } & \multicolumn{7}{|c|}{ Depth (cm) } \\
\hline & 35.6 & 36.3 & 36.8 & 37.2 & 37.7 & 38.0 & 38.4 \\
\hline Chamaepinnularia mediocris (212005) & & & & & & 1 & \\
\hline \multicolumn{8}{|l|}{ Chamaepinnularia soehrensis (212006) } \\
\hline \multicolumn{8}{|l|}{ Cocconeis placentula (16004) } \\
\hline Craticula halophila (21005) & & & & 2 & & 3 & \\
\hline \multicolumn{8}{|l|}{ Craticula riparia (21016) } \\
\hline Cyclotella comensis (20023) & & & & & & 1 & \\
\hline \multicolumn{8}{|l|}{ Cyclotella krammeri (20083) } \\
\hline Cyclotella ocellata (20009) & 29 & 19 & 18 & 26 & 38 & 22 & 30 \\
\hline Cyclotella rossii (20019) & 2 & 1 & 1 & 1 & & 1 & 1 \\
\hline Cyclotella tripartita (20085) & 6 & 3 & 7 & 7 & 5 & 7 & 6 \\
\hline \multicolumn{8}{|l|}{ Cymbella affinis (23073) } \\
\hline \multicolumn{8}{|l|}{ Cymbella amphicephala (23001) } \\
\hline \multicolumn{8}{|l|}{ Cymbella cesatii (23004) } \\
\hline \multicolumn{8}{|l|}{ Cymbella cistula (23005) } \\
\hline \multicolumn{8}{|l|}{ Cymbella helvetica (23099) } \\
\hline \multicolumn{8}{|l|}{ Cymbella heteropleura (23100) } \\
\hline \multicolumn{8}{|l|}{ Cymbella lapponica (23116) } \\
\hline \multicolumn{8}{|l|}{ Cymbella rupicola (23020) } \\
\hline \multicolumn{8}{|l|}{ Cymbella schimanskii } \\
\hline Cymbella sileiaca & 8 & 5 & 3 & 2 & 4 & 4 & 2 \\
\hline \multicolumn{8}{|l|}{ Cymbella tumidula (23082) } \\
\hline \multicolumn{8}{|l|}{ Cymbella tynnii (47141) } \\
\hline \multicolumn{8}{|l|}{ Cymbopleura angustata (190013) } \\
\hline \multicolumn{8}{|l|}{ Cymbopleura cuspidata (190001) } \\
\hline \multicolumn{8}{|l|}{ Cymbopleura subaequalis (190017) } \\
\hline \multicolumn{8}{|l|}{ Denticula elegans (25001) } \\
\hline \multicolumn{8}{|l|}{ Denticula keutzingii } \\
\hline \multicolumn{8}{|l|}{ Diatoma mesodon (27002) } \\
\hline \multicolumn{8}{|l|}{ Diatoma vulgaris (27013) } \\
\hline \multicolumn{8}{|l|}{ Diploneis boldtiana (30012) } \\
\hline \multicolumn{8}{|l|}{ Diploneis elliptica (30001) } \\
\hline Diploneis finnica (30002) & & & & & & & \\
\hline Diploneis marginestriata (30003) & 1 & 1 & & 2 & & 4 & \\
\hline Diploneis ovalis (30009) & & & 2 & & 2 & & \\
\hline Diploneis parma (30014) & & & & & & & \\
\hline Discostella pseudostelligera (2506002) & 8 & 11 & & 10 & 8 & 9 & 7 \\
\hline Discostella stelligera (2506003) & 4 & 4 & 3 & & 4 & 1 & \\
\hline
\end{tabular}




\begin{tabular}{|c|c|c|c|c|c|c|c|}
\hline \multirow[b]{2}{*}{ Updated Species Name } & \multicolumn{7}{|c|}{ Depth (cm) } \\
\hline & 35.6 & 36.3 & 36.8 & 37.2 & 37.7 & 38.0 & 38.4 \\
\hline \multicolumn{8}{|l|}{ Encyonema elginense (110044) } \\
\hline Encyonema gaeumannii (110008) & & 2 & & 2 & & 5 & \\
\hline \multicolumn{8}{|l|}{ Encyonema neogracile (110045) } \\
\hline Encyonopsis descripta (203014) & 1 & 1 & 1 & & 1 & 1 & 1 \\
\hline \multicolumn{8}{|l|}{ Encyonopsis falaisensis (203007) } \\
\hline \multicolumn{8}{|l|}{ Encyonopsis microcephala (203002) } \\
\hline Encyonopsis minuta (203011) & 6 & 1 & 1 & 2 & 2 & 1 & 3 \\
\hline \multicolumn{8}{|l|}{ Epithemia adnata (32003) } \\
\hline Epithemia smithii (32002) & & & 1 & & & & 2 \\
\hline \multicolumn{8}{|l|}{ Epithemia sorex (32006) } \\
\hline \multicolumn{8}{|l|}{ Eucocconeis flexella (187001) } \\
\hline \multicolumn{8}{|l|}{ Eucocconeis laevis (187002) } \\
\hline Eunotia arcus (33001) & 1 & 1 & 1 & 2 & 1 & & 1 \\
\hline Eunotia bigibba (33005) & & & & & & 1 & \\
\hline Eunotia bilunaris (33185) & & 1 & 1 & & & 1 & 1 \\
\hline \multicolumn{8}{|l|}{ Eunotia circumborealis (33210) } \\
\hline \multicolumn{8}{|l|}{ Eunotia denticulata (33011) } \\
\hline \multicolumn{8}{|l|}{ Eunotia exigua (33015) } \\
\hline Eunotia faba (33172) & 3 & 7 & & 1 & 5 & 2 & 2 \\
\hline \multicolumn{8}{|l|}{ Eunotia implicata (33168) } \\
\hline Eunotia incisa (33026) & & & & & & 1 & \\
\hline \multicolumn{8}{|l|}{ Eunotia minor (33183) } \\
\hline \multicolumn{8}{|l|}{ Eunotia monodon (33035) } \\
\hline \multicolumn{8}{|l|}{ Eunotia muscicola (33184) } \\
\hline \multicolumn{8}{|l|}{ Eunotia paludosa (33083) } \\
\hline \multicolumn{8}{|l|}{ Eunotia pectinalis (33039) } \\
\hline \multicolumn{8}{|l|}{ Eunotia praerupta (33045) } \\
\hline \multicolumn{8}{|l|}{ Eunotia rhomboidea (33051) } \\
\hline \multicolumn{8}{|l|}{ Eunotia rhynchocephala (33191) } \\
\hline \multicolumn{8}{|l|}{ Eunotia septentrionalis (33053) } \\
\hline Eunotia serra (33054) & & & & & & & 1 \\
\hline Eunotia soleirolii (33056) & & 1 & & & & 1 & \\
\hline Fragilaria capucina (34006) & 2 & & & & 2 & 2 & 2 \\
\hline Fragilaria delicatissima & & & & & & 1 & \\
\hline Frustulia krammeri (35039) & 1 & 4 & 1 & 2 & 1 & & \\
\hline Gomphonema acuminatum (37001) & 1 & & & 2 & & 1 & \\
\hline Gomphonema angustatum (37003) & & 2 & & & 1 & & 1 \\
\hline
\end{tabular}




\begin{tabular}{|c|c|c|c|c|c|c|c|}
\hline \multirow[b]{2}{*}{ Updated Species Name } & \multicolumn{2}{|c|}{ Depth (cm) } & \multirow[b]{2}{*}{36.8} & \multirow[b]{2}{*}{37.2} & \multirow[b]{2}{*}{37.7} & \multirow[b]{2}{*}{38.0} & \multirow[b]{2}{*}{38.4} \\
\hline & 35.6 & 36.3 & & & & & \\
\hline \multicolumn{8}{|l|}{ Gomphonema olivaceum (37065) } \\
\hline \multicolumn{8}{|l|}{ Gomphonema parvulum (37010) } \\
\hline \multicolumn{8}{|l|}{ Gomphonema pseudosphaerophorum } \\
\hline \multicolumn{8}{|l|}{ Gomphonema rhombicum (37080) } \\
\hline \multicolumn{8}{|l|}{ Gomphonema sarcophagus (37152) } \\
\hline \multicolumn{8}{|l|}{ Gomphonema truncatum (37022) } \\
\hline Karayevia laterostrata (125002) & & & & 1 & & & \\
\hline \multicolumn{8}{|l|}{ Karayevia ploenensis (125008) } \\
\hline Karayevia suchlandtii (125009) & 4 & 10 & 3 & 5 & & 6 & 3 \\
\hline \multicolumn{8}{|l|}{ Navicula absoluta (46494) } \\
\hline Navicula cryptocephala (46014) & 3 & & 1 & 1 & & & \\
\hline \multicolumn{8}{|l|}{ Navicula difficillima (46017) } \\
\hline \multicolumn{8}{|l|}{ Navicula levanderii } \\
\hline \multicolumn{8}{|l|}{ Navicula prominula } \\
\hline \multicolumn{8}{|l|}{ Navicula pseudobryophila (46807) } \\
\hline \multicolumn{8}{|l|}{ Navicula pseudoventralis (46166) } \\
\hline Navicula schmassmannii (46066) & & & & 3 & & 3 & \\
\hline Navicula striolata (93266) & & & & 2 & & & \\
\hline \multicolumn{8}{|l|}{ Navicula subrotundata (46079) } \\
\hline \multicolumn{8}{|l|}{ Navicula trivalis } \\
\hline \multicolumn{8}{|l|}{ Navicula viridula (46408) } \\
\hline \multicolumn{8}{|l|}{ Neidium affine (47001) } \\
\hline \multicolumn{8}{|l|}{ Neidium ampliatum (47066) } \\
\hline \multicolumn{8}{|l|}{ Neidium dubium (47011) } \\
\hline Neidium hitchcockii (47028) & & & & & & & \\
\hline Neidium iridis (47014) & & & & & & & \\
\hline Neidium septentrionalis (47110) & & & & & & & \\
\hline Nitzschia angustata (48093) & & & & & & & \\
\hline Nitzschia behrei (48585) & & & & & & & \\
\hline Nitzschia diversa (48411) & & & & & & & \\
\hline Nitzschia elegans (48010) & & & & & & & \\
\hline Nitzschia fonticola (48011) & 11 & 5 & 4 & 12 & 7 & 9 & 3 \\
\hline Nitzschia gisela (48624) & & & & & & & \\
\hline Nitzschia graciliformis (48119) & & & & & & & \\
\hline Nitzschia gracilis (48015) & & 1 & & & & & \\
\hline Nitzschia recta (48029) & & & & & & & \\
\hline Nitzschia tropica (48045) & & & & & & 1 & \\
\hline
\end{tabular}




\begin{tabular}{|c|c|c|c|c|c|c|c|}
\hline \multirow[b]{2}{*}{ Updated Species Name } & \multicolumn{7}{|c|}{ Depth (cm) } \\
\hline & 35.6 & 36.3 & 36.8 & 37.2 & 37.7 & 38.0 & 38.4 \\
\hline \multicolumn{8}{|l|}{ Nupela gracillima (92026) } \\
\hline \multicolumn{8}{|l|}{ Oxyneis binalis (9107001) } \\
\hline \multicolumn{8}{|l|}{ Pinnularia alpina (52807) } \\
\hline \multicolumn{8}{|l|}{ Pinnularia appendiculata (52009) } \\
\hline \multicolumn{8}{|l|}{ Pinnularia borealis (52013) } \\
\hline \multicolumn{8}{|l|}{ Pinnularia brauniana (103001) } \\
\hline \multicolumn{8}{|l|}{ Pinnularia divergens (52025) } \\
\hline \multicolumn{8}{|l|}{ Pinnularia episcopalis } \\
\hline \multicolumn{8}{|l|}{ Pinnularia gibba (52159) } \\
\hline Pinnularia interrupta (52194) & 1 & & & & & & \\
\hline \multicolumn{8}{|l|}{ Pinnularia karelica } \\
\hline Pinnularia microstauron (52045) & 1 & & & & & & \\
\hline \multicolumn{8}{|l|}{ Pinnularia nobilis (103038) } \\
\hline \multicolumn{8}{|l|}{ Pinnularia nodosa (52048) } \\
\hline \multicolumn{8}{|l|}{ Pinnularia polyonca (52087) } \\
\hline \multicolumn{8}{|l|}{ Pinnularia polyonca (52087) } \\
\hline \multicolumn{8}{|l|}{ Pinnularia pulchra (52801) } \\
\hline Pinnularia subcapitata (52059) & & 1 & 2 & 1 & 2 & 1 & 2 \\
\hline \multicolumn{8}{|l|}{ Pinnularia subrostrata (52184) } \\
\hline \multicolumn{8}{|l|}{ Pinnularia superdiverdentissima } \\
\hline Pinnularia viridis (52071) & 1 & & & & 1 & & 2 \\
\hline Placoneis elginensis (194005) & & & & & & & 1 \\
\hline \multicolumn{8}{|l|}{ Planothidium joursacense (155016) } \\
\hline \multicolumn{8}{|l|}{ Planothidium oestrupii (155026) } \\
\hline \multicolumn{8}{|l|}{ Platessa holsatica (2508002) } \\
\hline Psammothidium curtissimum (186021) & 2 & 3 & & 2 & & 1 & 1 \\
\hline Psammothidium didymum (186012) & 1 & 1 & & 1 & & 1 & 1 \\
\hline \multicolumn{8}{|l|}{ Psammothidium helveticum (186003) } \\
\hline \multicolumn{8}{|l|}{ Psammothidium ventralis (186009) } \\
\hline Pseudostaurosira brevistriata (73001) & 33 & 45 & 29 & 31 & 41 & 33 & 36 \\
\hline Pseudostaurosira elliptica (73025) & & 8 & & 5 & & 6 & \\
\hline Pseudostaurosira pseudoconstruens (73002) & 11 & 6 & 3 & 7 & 6 & 7 & 4 \\
\hline Puncticulata bodanica (208004) & 3 & 3 & & 1 & 2 & 2 & 12 \\
\hline \multicolumn{8}{|l|}{ Reimeria sinuata (55002) } \\
\hline Rossithidium nodosum (189006) & & 1 & & & & & \\
\hline Rossithidium pusillum (189003) & 6 & 9 & 4 & 4 & 9 & 6 & 8 \\
\hline Sellaphora pupula (170006) & 2 & & 2 & & 4 & 1 & 2 \\
\hline
\end{tabular}




\section{Depth (cm)}

Updated Species Name

$\begin{array}{lllllll}35.6 & 36.3 & 36.8 & 37.2 & 37.7 & 38.0 & 38.4\end{array}$

Stauroneis acuta (62036)

Stauroneis anceps (62002)

Stauroneis cf. javanica (62045)

Stauroneis cf. schimanskii (62127)

Stauroneis phoenicenteron (62015)

Stauroneis producta (62017)

1

Stauroneis prominula (62069)

Stauroneis thermicola (62040)

Staurosira construens (172001)

Staurosira construens var. binodis (172005)

Staurosira construens var. exigua (172022)

$\begin{array}{lllllll}3 & 3 & 4 & 4 & 6 & 2 & 8\end{array}$

Staurosira construens var. venter (172006)

$\begin{array}{lllllll}37 & 24 & 13 & 22 & 44 & 21 & 38\end{array}$

Staurosirella lapponica (175002)

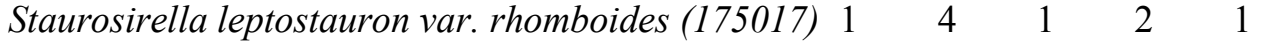

Staurosirella pinnata (175005)

$7 \quad 18$

135

Stenopterobia anceps (63003)

$\begin{array}{lllllll}27 & 14 & 27 & 20 & 30 & 19 & 17\end{array}$

Stenopterobia delicatissima (63007)

Surirella amphioxys (65069)

Surirella angusta (65002)

Surirella elegans (65072)

Surirella gracilis (65013)

Surirella linearis (65014)

Tabellaria fenestrata (67002)

Tabellaria flocculosa (67004)

Tabularia fasciculata (200002)

Tetracyclus glans (71006)

Tetracyclus lacustris (71003)

\begin{tabular}{|c|c|c|c|c|c|c|c|}
\hline Total chrysophyte cysts per slice & & 53 & & 69 & & 59 & \\
\hline Total diatom counts per slice & 441 & 511 & 401 & 422 & 450 & 432 & 461 \\
\hline Total microspheres per slice & & 42 & & 70 & & 22 & \\
\hline
\end{tabular}




\begin{tabular}{|c|c|c|c|c|c|c|c|}
\hline \multirow[b]{2}{*}{ Updated Species Name } & \multicolumn{7}{|c|}{ Depth (cm) } \\
\hline & 38.8 & 39.5 & 39.7 & 39.9 & 40.6 & 41.4 & 41.6 \\
\hline \multicolumn{8}{|l|}{ Achnanthes imperfecta (2051) } \\
\hline Achnanthes levanderi (2022) & 9 & 10 & 9 & 3 & 8 & 9 & 6 \\
\hline Achnanthes pergalli & & & & & 1 & & \\
\hline Achnanthes pseudoswazi (2206) & & & & & & & 2 \\
\hline \multicolumn{8}{|l|}{ Achnanthes trinodis (2109) } \\
\hline Achnanthidium minutissimum (1010) & 25 & 15 & 30 & 23 & 31 & 12 & 49 \\
\hline Achnanthidium semiapertum (1028) & & 1 & & & & & \\
\hline \multicolumn{8}{|l|}{ Amphipleura lindheimerii } \\
\hline \multicolumn{8}{|l|}{ Amphora copulata (7075) } \\
\hline Amphora ovalis (7001) & & & & 1 & & & \\
\hline Aulacoseira alpigena (10028) & 106 & 195 & 126 & 165 & 90 & 130 & 82 \\
\hline \multicolumn{8}{|l|}{ Aulacoseira ambigua (10008) } \\
\hline \multicolumn{8}{|l|}{ Aulacoseira canadensis (10003) } \\
\hline \multicolumn{8}{|l|}{ Aulacoseira crassipunctata (10001) } \\
\hline Aulacoseira distans (10009) & 22 & 20 & 20 & 9 & 18 & 6 & 56 \\
\hline \multicolumn{8}{|l|}{ Aulacoseira granulata (10018) } \\
\hline \multicolumn{8}{|l|}{ Aulacoseira italica (10019) } \\
\hline Aulacoseira lacustris (10060) & 18 & 5 & 18 & 2 & 25 & & 17 \\
\hline \multicolumn{8}{|l|}{ Aulacoseira lirata (10012) } \\
\hline \multicolumn{8}{|l|}{ Aulacoseira muzzanensis (10031) } \\
\hline Aulacoseira perglabra (10006) & 7 & & 7 & & 10 & & 6 \\
\hline Aulacoseira subarctica (10015) & 6 & 11 & 6 & 4 & 9 & & 1 \\
\hline Aulacoseira tethera (10033) & 1 & 1 & 2 & & & & \\
\hline Aulacoseira valida (10029) & & & & & 1 & & \\
\hline \multicolumn{8}{|l|}{ Bacillaria paradoxa (76001) } \\
\hline Brachysira brebissonii (18005) & 3 & 6 & 7 & 2 & 7 & 6 & 11 \\
\hline Brachysira microcephala (18013) & 2 & 4 & & & & 2 & \\
\hline \multicolumn{8}{|l|}{ Caloneis alpestris (12025) } \\
\hline \multicolumn{8}{|l|}{ Caloneis lauta (12026) } \\
\hline \multicolumn{8}{|l|}{ Caloneis permagna (12030) } \\
\hline Caloneis silicula (12010) & & & & & 1 & & \\
\hline \multicolumn{8}{|l|}{ Caloneis tenuis (12013) } \\
\hline \multicolumn{8}{|l|}{ Caloneis thermalis (12054) } \\
\hline \multicolumn{8}{|l|}{ Caloneis undulata (12022) } \\
\hline \multicolumn{8}{|l|}{ Caloneis westii (12056) } \\
\hline Cavinula cocconeiformis (195001) & 5 & 3 & 3 & & 2 & & 6 \\
\hline Cavinula pseudoscutiformis (195003) & 8 & 3 & 3 & 1 & 2 & 2 & 1 \\
\hline
\end{tabular}




\begin{tabular}{|c|c|c|c|c|c|c|c|}
\hline \multicolumn{8}{|c|}{ Depth (cm) } \\
\hline Updated Species Name & 38.8 & 39.5 & 39.7 & 39.9 & 40.6 & 41.4 & 41.6 \\
\hline Chamaepinnularia mediocris (212005) & 4 & & & & & & \\
\hline Chamaepinnularia soehrensis (212006) & & & & & & & \\
\hline Cocconeis placentula (16004) & & & & & & & \\
\hline Craticula halophila (21005) & 1 & 1 & & 1 & & & \\
\hline Craticula riparia (21016) & & & & & & & \\
\hline Cyclotella comensis (20023) & & & & & & & 1 \\
\hline Cyclotella krammeri (20083) & & & & & & & \\
\hline Cyclotella ocellata (20009) & 22 & 21 & 31 & 43 & 27 & 23 & 34 \\
\hline Cyclotella rossii (20019) & 1 & & & 1 & & & 3 \\
\hline Cyclotella tripartita (20085) & 12 & 7 & 6 & 5 & 4 & 11 & 5 \\
\hline Cymbella affinis (23073) & & & & & & & \\
\hline Cymbella amphicephala (23001) & & & & & & & \\
\hline Cymbella cesatii (23004) & & & & & & & \\
\hline Cymbella cistula (23005) & & & & & & & \\
\hline Cymbella helvetica (23099) & & & & & & & \\
\hline Cymbella heteropleura (23100) & & & & & & & \\
\hline Cymbella lapponica (23116) & & & 1 & & & & \\
\hline Cymbella rupicola (23020) & & & & & & & \\
\hline Cymbella schimanskii & & & & & & & \\
\hline Cymbella sileiaca & & 4 & 2 & 2 & 1 & 2 & 5 \\
\hline Cymbella tumidula (23082) & & & & & & & \\
\hline Cymbella tynnii (47141) & & & & & & & \\
\hline Cymbopleura angustata (190013) & & & & & & & \\
\hline Cymbopleura cuspidata (190001) & & & & & & & \\
\hline Cymbopleura subaequalis (190017) & & & & & & & \\
\hline Denticula elegans (25001) & & & & & & & \\
\hline Denticula keutzingii & & & & & & & \\
\hline Diatoma mesodon (27002) & & & & & & & \\
\hline Diatoma vulgaris (27013) & & & & & & & \\
\hline Diploneis boldtiana (30012) & & & & & & & \\
\hline Diploneis elliptica (30001) & & & & & & & \\
\hline Diploneis finnica (30002) & & & & & & & \\
\hline Diploneis marginestriata (30003) & & & & & & & \\
\hline Diploneis ovalis (30009) & & & & & & & \\
\hline Diploneis parma (30014) & & & & & & & \\
\hline Discostella pseudostelligera (2506002) & 11 & 8 & 4 & 9 & 4 & 10 & 3 \\
\hline Discostella stelligera (2506003) & & 3 & 5 & 4 & 6 & 2 & 6 \\
\hline
\end{tabular}




\begin{tabular}{|c|c|c|c|c|c|c|c|}
\hline \multirow[b]{2}{*}{ Updated Species Name } & \multicolumn{7}{|c|}{ Depth (cm) } \\
\hline & 38.8 & 39.5 & 39.7 & 39.9 & 40.6 & 41.4 & 41.6 \\
\hline Encyonema elginense (110044) & & 1 & & & & 1 & \\
\hline Encyonema gaeumannii (110008) & 2 & & 1 & & & & 1 \\
\hline Encyonema neogracile (110045) & & & & & & & \\
\hline Encyonopsis descripta (203014) & 9 & & 2 & & & 1 & 3 \\
\hline Encyonopsis falaisensis (203007) & & & & & & & \\
\hline Encyonopsis microcephala (203002) & & & & & & & \\
\hline Encyonopsis minuta (203011) & 5 & 2 & 2 & 2 & 1 & 4 & 4 \\
\hline Epithemia adnata (32003) & & & & & & & \\
\hline Epithemia smithii (32002) & & & & 1 & & & 1 \\
\hline Epithemia sorex (32006) & & & & & & & \\
\hline Eucocconeis flexella (187001) & & 1 & & & & 3 & \\
\hline Eucocconeis laevis (187002) & & & & & & & \\
\hline Eunotia arcus (33001) & & & & & & & \\
\hline Eunotia bigibba (33005) & & & & & 1 & 1 & \\
\hline Eunotia bilunaris (33185) & 1 & 2 & & & 2 & & 1 \\
\hline Eunotia circumborealis (33210) & & & & & & & \\
\hline Eunotia denticulata (33011) & & & & & & & \\
\hline Eunotia exigua (33015) & & & & & & & \\
\hline Eunotia faba (33172) & 2 & 2 & 3 & 5 & 2 & 5 & 3 \\
\hline Eunotia implicata (33168) & & & & & & & \\
\hline Eunotia incisa (33026) & & & & & & & \\
\hline Eunotia minor (33183) & & & & & & & \\
\hline Eunotia monodon (33035) & & & & & & & \\
\hline Eunotia muscicola (33184) & & & & & & & \\
\hline Eunotia paludosa (33083) & & & & & & & \\
\hline Eunotia pectinalis (33039) & & & & & & & \\
\hline Eunotia praerupta (33045) & & & & & & & \\
\hline Eunotia rhomboidea (33051) & & & & & & & \\
\hline Eunotia rhynchocephala (33191) & & & & & & & \\
\hline Eunotia septentrionalis (33053) & 1 & & & & & & \\
\hline Eunotia serra (33054) & & & & 1 & & 2 & 1 \\
\hline Eunotia soleirolii (33056) & & & & & & & \\
\hline Fragilaria capucina (34006) & 1 & 1 & & & 1 & 1 & 2 \\
\hline Fragilaria delicatissima & & & & & & & \\
\hline Frustulia krammeri (35039) & 1 & 3 & 3 & 1 & & 2 & 1 \\
\hline Gomphonema acuminatum (37001) & & 1 & & & & 2 & \\
\hline Gomphonema angustatum (37003) & 1 & 1 & & 1 & & 3 & 1 \\
\hline
\end{tabular}




\begin{tabular}{|c|c|c|c|c|c|c|c|}
\hline \multirow[b]{2}{*}{ Updated Species Name } & \multicolumn{7}{|c|}{ Depth (cm) } \\
\hline & 38.8 & 39.5 & 39.7 & 39.9 & 40.6 & 41.4 & 41.6 \\
\hline \multicolumn{8}{|l|}{ Gomphonema olivaceum (37065) } \\
\hline \multicolumn{8}{|l|}{ Gomphonema parvulum (37010) } \\
\hline \multicolumn{8}{|l|}{ Gomphonema pseudosphaerophorum } \\
\hline \multicolumn{8}{|l|}{ Gomphonema rhombicum (37080) } \\
\hline Gomphonema sarcophagus (37152) & & & & & & & 1 \\
\hline \multicolumn{8}{|l|}{ Gomphonema truncatum (37022) } \\
\hline \multicolumn{8}{|l|}{ Karayevia laterostrata (125002) } \\
\hline \multicolumn{8}{|l|}{ Karayevia ploenensis (125008) } \\
\hline Karayevia suchlandtii (125009) & 3 & 2 & 3 & 2 & 3 & 1 & 4 \\
\hline \multicolumn{8}{|l|}{ Navicula absoluta (46494) } \\
\hline Navicula cryptocephala (46014) & 1 & 1 & 1 & & 1 & & 1 \\
\hline \multicolumn{8}{|l|}{ Navicula difficillima (46017) } \\
\hline \multicolumn{8}{|l|}{ Navicula levanderii } \\
\hline \multicolumn{8}{|l|}{ Navicula prominula } \\
\hline \multicolumn{8}{|l|}{ Navicula pseudobryophila (46807) } \\
\hline \multicolumn{8}{|l|}{ Navicula pseudoventralis (46166) } \\
\hline Navicula schmassmannii (46066) & 3 & & & 1 & 4 & 2 & 3 \\
\hline \multicolumn{8}{|l|}{ Navicula striolata (93266) } \\
\hline \multicolumn{8}{|l|}{ Navicula subrotundata (46079) } \\
\hline \multicolumn{8}{|l|}{ Navicula trivalis } \\
\hline \multicolumn{8}{|l|}{ Navicula viridula (46408) } \\
\hline Neidium affine (47001) & & & & & & & 1 \\
\hline Neidium ampliatum (47066) & 1 & & & & & & \\
\hline Neidium dubium (47011) & & 1 & & & & & \\
\hline \multicolumn{8}{|l|}{ Neidium hitchcockii (47028) } \\
\hline \multicolumn{8}{|l|}{ Neidium iridis (47014) } \\
\hline \multicolumn{8}{|l|}{ Neidium septentrionalis (47110) } \\
\hline \multicolumn{8}{|l|}{ Nitzschia angustata (48093) } \\
\hline \multicolumn{8}{|l|}{ Nitzschia behrei (48585) } \\
\hline \multicolumn{8}{|l|}{ Nitzschia diversa (48411) } \\
\hline \multicolumn{8}{|l|}{ Nitzschia elegans (48010) } \\
\hline Nitzschia fonticola (48011) & 18 & 11 & 12 & 12 & 11 & 11 & 13 \\
\hline Nitzschia gisela (48624) & & & & & & & \\
\hline Nitzschia graciliformis (48119) & & & & & & & \\
\hline Nitzschia gracilis (48015) & & & & & & & \\
\hline Nitzschia recta (48029) & & & & & & & \\
\hline Nitzschia tropica (48045) & & & & & & & \\
\hline
\end{tabular}




\begin{tabular}{|c|c|c|c|c|c|c|c|}
\hline \multirow[b]{2}{*}{ Updated Species Name } & \multicolumn{2}{|c|}{ Depth (cm) } & \multirow[b]{2}{*}{39.7} & \multirow[b]{2}{*}{39.9} & \multirow[b]{2}{*}{40.6} & \multirow[b]{2}{*}{41.4} & \multirow[b]{2}{*}{41.6} \\
\hline & 38.8 & 39.5 & & & & & \\
\hline \multicolumn{8}{|l|}{ Nupela gracillima (92026) } \\
\hline \multicolumn{8}{|l|}{ Oxyneis binalis (9107001) } \\
\hline \multicolumn{8}{|l|}{ Pinnularia alpina (52807) } \\
\hline \multicolumn{8}{|l|}{ Pinnularia appendiculata (52009) } \\
\hline \multicolumn{8}{|l|}{ Pinnularia borealis (52013) } \\
\hline \multicolumn{8}{|l|}{ Pinnularia brauniana (103001) } \\
\hline \multicolumn{8}{|l|}{ Pinnularia divergens (52025) } \\
\hline \multicolumn{8}{|l|}{ Pinnularia episcopalis } \\
\hline \multicolumn{8}{|l|}{ Pinnularia gibba (52159) } \\
\hline \multicolumn{8}{|l|}{ Pinnularia interrupta (52194) } \\
\hline \multicolumn{8}{|l|}{ Pinnularia karelica } \\
\hline \multicolumn{8}{|l|}{ Pinnularia microstauron (52045) } \\
\hline \multicolumn{8}{|l|}{ Pinnularia nobilis (103038) } \\
\hline \multicolumn{8}{|l|}{ Pinnularia nodosa (52048) } \\
\hline \multicolumn{8}{|l|}{ Pinnularia polyonca (52087) } \\
\hline \multicolumn{8}{|l|}{ Pinnularia polyonca (52087) } \\
\hline \multicolumn{8}{|l|}{ Pinnularia pulchra (52801) } \\
\hline Pinnularia subcapitata (52059) & 1 & 2 & 3 & 2 & 1 & 3 & 1 \\
\hline \multicolumn{8}{|l|}{ Pinnularia subrostrata (52184) } \\
\hline \multicolumn{8}{|l|}{ Pinnularia superdiverdentissima } \\
\hline Pinnularia viridis (52071) & & & & & & 1 & \\
\hline Placoneis elginensis (194005) & & & & & & & \\
\hline Planothidium joursacense (155016) & & & & & & & \\
\hline Planothidium oestrupii (155026) & & & & & & & \\
\hline Platessa holsatica (2508002) & & & & & & & \\
\hline Psammothidium curtissimum (186021) & 8 & 4 & 3 & 2 & 5 & & 5 \\
\hline Psammothidium didymum (186012) & & & & & 1 & & 1 \\
\hline Psammothidium helveticum (186003) & & & & & & & \\
\hline Psammothidium ventralis (186009) & 3 & & 1 & & & & \\
\hline Pseudostaurosira brevistriata (73001) & 24 & 35 & 44 & 38 & 23 & 24 & 18 \\
\hline Pseudostaurosira elliptica (73025) & 10 & & 1 & & 7 & & 9 \\
\hline Pseudostaurosira pseudoconstruens (73002) & 17 & 9 & 6 & 4 & 8 & 5 & 7 \\
\hline Puncticulata bodanica (208004) & 2 & 2 & 5 & 2 & & 6 & 9 \\
\hline Reimeria sinuata (55002) & & & & & & & \\
\hline Rossithidium nodosum (189006) & & & 2 & & 15 & & 11 \\
\hline Rossithidium pusillum (189003) & 9 & 8 & 4 & 12 & 6 & 10 & 6 \\
\hline Sellaphora pupula (170006) & 8 & 3 & 1 & & 1 & 1 & 7 \\
\hline
\end{tabular}




\section{Depth (cm)}

Updated Species Name

$\begin{array}{lllllll}38.8 & 39.5 & 39.7 & 39.9 & 40.6 & 41.4 & 41.6\end{array}$

Stauroneis acuta (62036)

Stauroneis anceps (62002)

Stauroneis cf. javanica (62045)

Stauroneis cf. schimanskii (62127)

Stauroneis phoenicenteron (62015)

Stauroneis producta (62017)

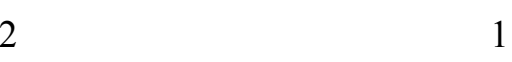

Stauroneis prominula (62069)

Stauroneis thermicola (62040)

Staurosira construens (172001)

Staurosira construens var. binodis (172005)

Staurosira construens var. exigua (172022)

$\begin{array}{lllllll} & & 1 & & 2 & & 1 \\ & 4 & 10 & 8 & 11 & 22 & 11 \\ 15 & 32 & 30 & 33 & 38 & 34 & 27 \\ 22 & 20 & 14 & 27 & 27 & 24 & 29 \\ & & & & 6 & & 8 \\ 1 & 3 & 3 & 1 & & 2 & 1 \\ 7 & 14 & 15 & 9 & 24 & 2 & 7\end{array}$

Staurosira construens var. venter (172006)

Staurosirella lapponica (175002)

Staurosirella leptostauron var. rhomboides (175017)

Staurosirella pinnata (175005)

Stenopterobia anceps (63003)

Stenopterobia delicatissima (63007)

Surirella amphioxys (65069)

Surirella angusta (65002)

Surirella elegans (65072)

Surirella gracilis (65013)

Surirella linearis (65014)

Tabellaria fenestrata (67002)

Tabellaria flocculosa (67004)

$\begin{array}{rllllll} & 3 & 2 & 1 & 4 & 3 & 3 \\ 5 & 4 & 5 & 3 & 5 & & 8\end{array}$

Tabularia fasciculata (200002)

Tetracyclus glans (71006)

Tetracyclus lacustris (71003)

\begin{tabular}{|c|c|c|c|c|c|c|c|}
\hline Total chrysophyte cysts per slice & $\overline{660}$ & & $\overline{53}$ & & 47 & & 64 \\
\hline Total diatom counts per slice & 446 & 490 & 459 & 443 & 458 & 393 & 504 \\
\hline Total microspheres per slice & 37 & & 130 & & 16 & & 28 \\
\hline
\end{tabular}




\begin{tabular}{|c|c|c|c|c|c|c|c|}
\hline \multirow[b]{2}{*}{ Updated Species Name } & \multicolumn{7}{|c|}{ Depth (cm) } \\
\hline & 41.8 & 42.6 & 43.3 & 43.5 & 44.2 & 44.3 & 45.2 \\
\hline \multicolumn{8}{|l|}{ Achnanthes imperfecta (2051) } \\
\hline Achnanthes levanderi (2022) & 3 & 12 & 6 & 8 & 3 & 13 & 12 \\
\hline Achnanthes pergalli & & & & & & 1 & 3 \\
\hline Achnanthes pseudoswazi (2206) & & & 1 & 1 & & 1 & 2 \\
\hline \multicolumn{8}{|l|}{ Achnanthes trinodis (2109) } \\
\hline Achnanthidium minutissimum (1010) & 23 & 51 & 30 & 43 & 15 & 39 & 41 \\
\hline \multicolumn{8}{|l|}{ Achnanthidium semiapertum (1028) } \\
\hline \multicolumn{8}{|l|}{ Amphipleura lindheimerii } \\
\hline \multicolumn{8}{|l|}{ Amphora copulata (7075) } \\
\hline Amphora ovalis (7001) & 1 & & & & & & \\
\hline Aulacoseira alpigena (10028) & 132 & 75 & 152 & 67 & 150 & 78 & 67 \\
\hline Aulacoseira ambigua (10008) & & 1 & & & & & 2 \\
\hline \multicolumn{8}{|l|}{ Aulacoseira canadensis (10003) } \\
\hline \multicolumn{8}{|l|}{ Aulacoseira crassipunctata (10001) } \\
\hline Aulacoseira distans (10009) & 4 & 32 & 12 & 45 & 6 & 30 & 33 \\
\hline \multicolumn{8}{|l|}{ Aulacoseira granulata (10018) } \\
\hline \multicolumn{8}{|l|}{ Aulacoseira italica (10019) } \\
\hline Aulacoseira lacustris (10060) & & 20 & 5 & 28 & 2 & 15 & 20 \\
\hline \multicolumn{8}{|l|}{ Aulacoseira lirata (10012) } \\
\hline \multicolumn{8}{|l|}{ Aulacoseira muzzanensis (10031) } \\
\hline Aulacoseira perglabra (10006) & & 2 & & 6 & & 7 & 2 \\
\hline Aulacoseira subarctica (10015) & 4 & 3 & 8 & 9 & 11 & 11 & 11 \\
\hline Aulacoseira tethera (10033) & & & & & & & 3 \\
\hline \multicolumn{8}{|l|}{ Aulacoseira valida (10029) } \\
\hline \multicolumn{8}{|l|}{ Bacillaria paradoxa (76001) } \\
\hline Brachysira brebissonii (18005) & 6 & 7 & 4 & 8 & & 9 & 12 \\
\hline Brachysira microcephala (18013) & 1 & 1 & & 1 & 2 & 2 & 2 \\
\hline \multicolumn{8}{|l|}{ Caloneis alpestris (12025) } \\
\hline \multicolumn{8}{|l|}{ Caloneis lauta (12026) } \\
\hline \multicolumn{8}{|l|}{ Caloneis permagna (12030) } \\
\hline \multicolumn{8}{|l|}{ Caloneis silicula (12010) } \\
\hline \multicolumn{8}{|l|}{ Caloneis tenuis (12013) } \\
\hline Caloneis thermalis (12054) & & & & & & 1 & \\
\hline \multicolumn{8}{|l|}{ Caloneis undulata (12022) } \\
\hline \multicolumn{8}{|l|}{ Caloneis westii (12056) } \\
\hline Cavinula cocconeiformis (195001) & 2 & 2 & 3 & 3 & 1 & 5 & 4 \\
\hline Cavinula pseudoscutiformis (195003) & 5 & 1 & 3 & 2 & 8 & 3 & 9 \\
\hline
\end{tabular}




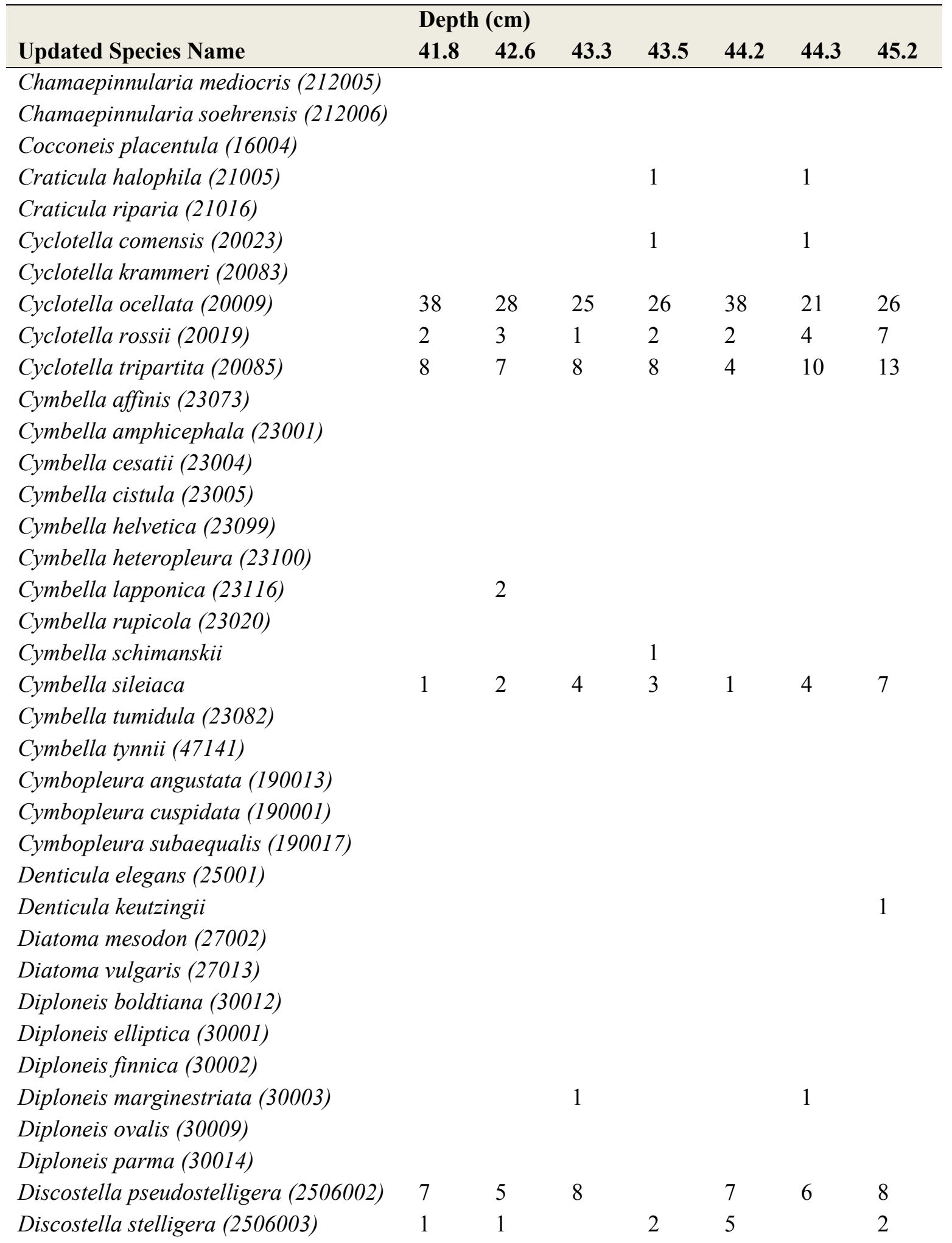




\begin{tabular}{|c|c|c|c|c|c|c|c|}
\hline \multirow[b]{2}{*}{ Updated Species Name } & \multicolumn{7}{|c|}{ Depth (cm) } \\
\hline & 41.8 & 42.6 & 43.3 & 43.5 & 44.2 & 44.3 & 45.2 \\
\hline \multicolumn{8}{|l|}{ Encyonema elginense (110044) } \\
\hline Encyonema gaeumannii (110008) & & 1 & & 1 & & 5 & 4 \\
\hline \multicolumn{8}{|l|}{ Encyonema neogracile (110045) } \\
\hline Encyonopsis descripta (203014) & 3 & & 2 & 3 & 2 & & \\
\hline \multicolumn{8}{|l|}{ Encyonopsis falaisensis (203007) } \\
\hline \multicolumn{8}{|l|}{ Encyonopsis microcephala (203002) } \\
\hline Encyonopsis minuta (203011) & 3 & 2 & 1 & 1 & 6 & 1 & 1 \\
\hline \multicolumn{8}{|l|}{ Epithemia adnata (32003) } \\
\hline Epithemia smithii (32002) & & & & 1 & 1 & & \\
\hline \multicolumn{8}{|l|}{ Epithemia sorex (32006) } \\
\hline Eucocconeis flexella (187001) & & & & & 1 & & \\
\hline \multicolumn{8}{|l|}{ Eucocconeis laevis (187002) } \\
\hline Eunotia arcus (33001) & & 1 & & & & & \\
\hline Eunotia bigibba (33005) & 1 & & & 1 & & 1 & \\
\hline Eunotia bilunaris (33185) & 1 & & 1 & & & & 2 \\
\hline \multicolumn{8}{|l|}{ Eunotia circumborealis (33210) } \\
\hline \multicolumn{8}{|l|}{ Eunotia denticulata (33011) } \\
\hline \multicolumn{8}{|l|}{ Eunotia exigua (33015) } \\
\hline Eunotia faba (33172) & 4 & 1 & 3 & 3 & 2 & 1 & \\
\hline Eunotia implicata (33168) & & & & & & 1 & \\
\hline \multicolumn{8}{|l|}{ Eunotia incisa (33026) } \\
\hline \multicolumn{8}{|l|}{ Eunotia minor (33183) } \\
\hline \multicolumn{8}{|l|}{ Eunotia monodon (33035) } \\
\hline \multicolumn{8}{|l|}{ Eunotia muscicola (33184) } \\
\hline \multicolumn{8}{|l|}{ Eunotia paludosa (33083) } \\
\hline \multicolumn{8}{|l|}{ Eunotia pectinalis (33039) } \\
\hline \multicolumn{8}{|l|}{ Eunotia praerupta (33045) } \\
\hline \multicolumn{8}{|l|}{ Eunotia rhomboidea (33051) } \\
\hline \multicolumn{8}{|l|}{ Eunotia rhynchocephala (33191) } \\
\hline \multicolumn{8}{|l|}{ Eunotia septentrionalis (33053) } \\
\hline Eunotia serra (33054) & 1 & 1 & 3 & & & & \\
\hline \multicolumn{8}{|l|}{ Eunotia soleirolii (33056) } \\
\hline Fragilaria capucina (34006) & 1 & 3 & & 1 & 2 & 2 & 2 \\
\hline \multicolumn{8}{|l|}{ Fragilaria delicatissima } \\
\hline Frustulia krammeri (35039) & & 1 & & & 1 & 3 & 1 \\
\hline Gomphonema acuminatum (37001) & 1 & & & & 1 & 1 & \\
\hline Gomphonema angustatum (37003) & 1 & & 2 & & 1 & & \\
\hline
\end{tabular}




\begin{tabular}{|c|c|c|c|c|c|c|c|}
\hline \multirow[b]{2}{*}{ Updated Species Name } & \multicolumn{7}{|c|}{ Depth (cm) } \\
\hline & 41.8 & 42.6 & 43.3 & 43.5 & 44.2 & 44.3 & 45.2 \\
\hline \multicolumn{8}{|l|}{ Gomphonema olivaceum (37065) } \\
\hline \multicolumn{8}{|l|}{ Gomphonema parvulum (37010) } \\
\hline \multicolumn{8}{|l|}{ Gomphonema pseudosphaerophorum } \\
\hline \multicolumn{8}{|l|}{ Gomphonema rhombicum (37080) } \\
\hline Gomphonema sarcophagus (37152) & & & & 3 & & 1 & 2 \\
\hline \multicolumn{8}{|l|}{ Gomphonema truncatum (37022) } \\
\hline \multicolumn{8}{|l|}{ Karayevia laterostrata (125002) } \\
\hline \multicolumn{8}{|l|}{ Karayevia ploenensis (125008) } \\
\hline Karayevia suchlandtii (125009) & 3 & 3 & 2 & 8 & 5 & 8 & 6 \\
\hline \multicolumn{8}{|l|}{ Navicula absoluta (46494) } \\
\hline Navicula cryptocephala (46014) & 1 & 2 & 1 & & 1 & 2 & 2 \\
\hline \multicolumn{8}{|l|}{ Navicula difficillima (46017) } \\
\hline \multicolumn{8}{|l|}{ Navicula levanderii } \\
\hline \multicolumn{8}{|l|}{ Navicula prominula } \\
\hline \multicolumn{8}{|l|}{ Navicula pseudobryophila (46807) } \\
\hline \multicolumn{8}{|l|}{ Navicula pseudoventralis (46166) } \\
\hline Navicula schmassmannii (46066) & 1 & 3 & & 3 & 1 & 1 & 2 \\
\hline \multicolumn{8}{|l|}{ Navicula striolata (93266) } \\
\hline \multicolumn{8}{|l|}{ Navicula subrotundata (46079) } \\
\hline Navicula trivalis & & 1 & & & & & \\
\hline \multicolumn{8}{|l|}{ Navicula viridula (46408) } \\
\hline \multicolumn{8}{|l|}{ Neidium affine (47001) } \\
\hline \multicolumn{8}{|l|}{ Neidium ampliatum (47066) } \\
\hline \multicolumn{8}{|l|}{ Neidium dubium (47011) } \\
\hline \multicolumn{8}{|l|}{ Neidium hitchcockii (47028) } \\
\hline \multicolumn{8}{|l|}{ Neidium iridis (47014) } \\
\hline \multicolumn{8}{|l|}{ Neidium septentrionalis (47110) } \\
\hline \multicolumn{8}{|l|}{ Nitzschia angustata (48093) } \\
\hline \multicolumn{8}{|l|}{ Nitzschia behrei (48585) } \\
\hline Nitzschia diversa (48411) & & & & & & & \\
\hline Nitzschia elegans (48010) & & & & & & & \\
\hline Nitzschia fonticola (48011) & 9 & 9 & 7 & 7 & 5 & 10 & 20 \\
\hline Nitzschia gisela (48624) & & & & & & & \\
\hline Nitzschia graciliformis (48119) & & & & & & & \\
\hline Nitzschia gracilis (48015) & & & & & & & \\
\hline Nitzschia recta (48029) & & & & & & & \\
\hline Nitzschia tropica (48045) & & & & & & & \\
\hline
\end{tabular}




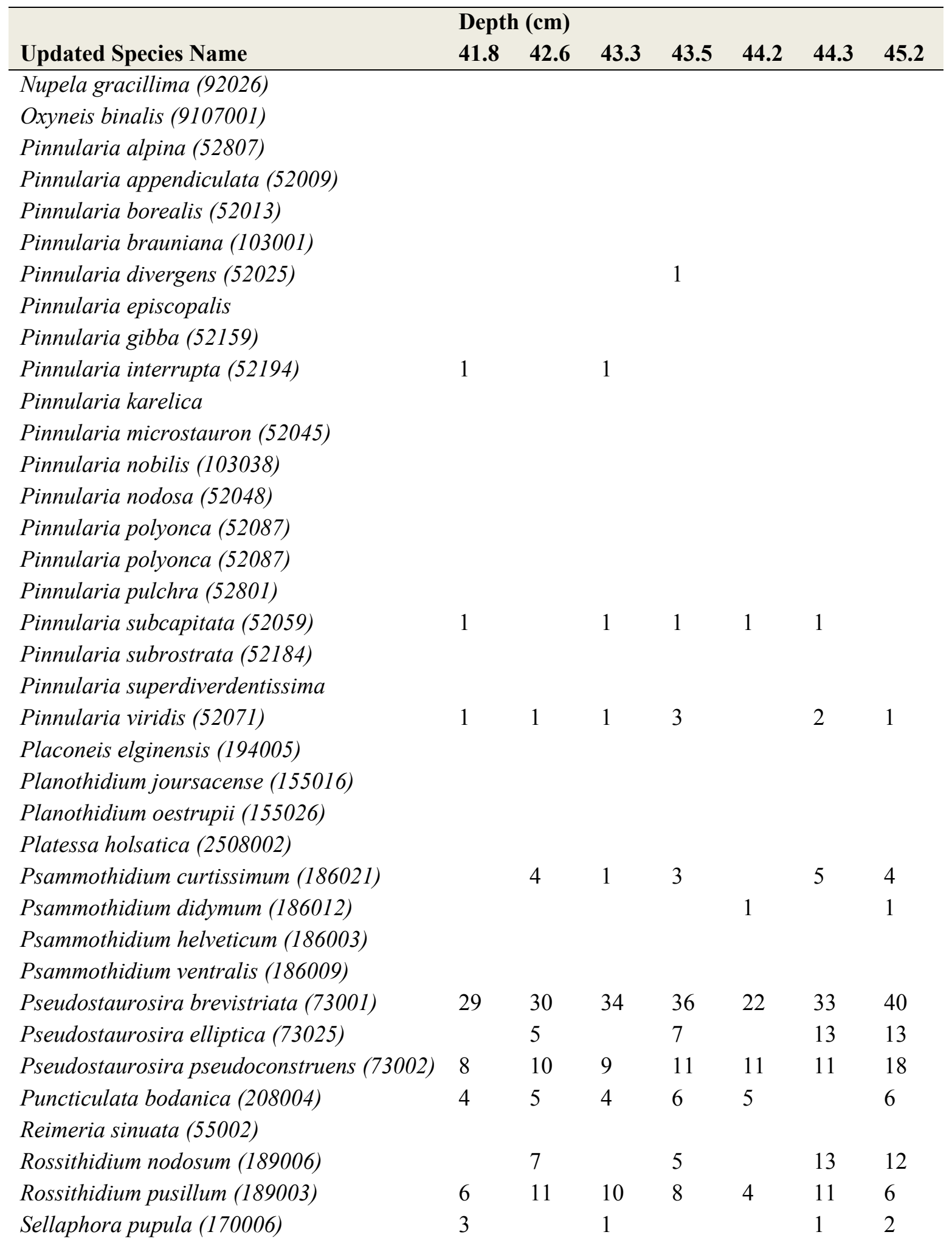




\begin{tabular}{|c|c|c|c|c|c|c|c|}
\hline \multirow[b]{2}{*}{ Updated Species Name } & \multicolumn{7}{|c|}{ Depth (cm) } \\
\hline & 41.8 & 42.6 & 43.3 & 43.5 & 44.2 & 44.3 & 45.2 \\
\hline \multicolumn{8}{|l|}{ Stauroneis acuta (62036) } \\
\hline \multicolumn{8}{|l|}{ Stauroneis anceps (62002) } \\
\hline \multicolumn{8}{|l|}{ Stauroneis cf. javanica (62045) } \\
\hline \multicolumn{8}{|l|}{ Stauroneis cf. schimanskii (62127) } \\
\hline Stauroneis phoenicenteron (62015) & & & & & & & 1 \\
\hline Stauroneis producta (62017) & 1 & & & & 1 & & \\
\hline Stauroneis prominula (62069) & & & & 1 & & 1 & \\
\hline \multicolumn{8}{|l|}{ Stauroneis thermicola (62040) } \\
\hline Staurosira construens (172001) & & & & & & 2 & \\
\hline Staurosira construens var. binodis (172005) & 5 & 7 & 5 & 9 & 5 & 3 & 8 \\
\hline Staurosira construens var. exigua (172022) & 32 & 25 & 24 & 21 & 26 & 22 & 31 \\
\hline Staurosira construens var. venter (172006) & 39 & 25 & 25 & 25 & 31 & 24 & 23 \\
\hline Staurosirella lapponica (175002) & & 2 & & 5 & & 3 & 3 \\
\hline $\begin{array}{l}\text { Staurosirella leptostauron var. rhomboides } \\
\text { (175017) }\end{array}$ & & 1 & & & 1 & 3 & 1 \\
\hline Staurosirella pinnata (175005) & 6 & 20 & 13 & 27 & 6 & 38 & 30 \\
\hline \multicolumn{8}{|l|}{ Stenopterobia anceps (63003) } \\
\hline \multicolumn{8}{|l|}{ Stenopterobia delicatissima (63007) } \\
\hline \multicolumn{8}{|l|}{ Surirella amphioxys (65069) } \\
\hline \multicolumn{8}{|l|}{ Surirella angusta (65002) } \\
\hline \multicolumn{8}{|l|}{ Surirella elegans (65072) } \\
\hline \multicolumn{8}{|l|}{ Surirella gracilis (65013) } \\
\hline \multicolumn{8}{|l|}{ Surirella linearis (65014) } \\
\hline Tabellaria fenestrata (67002) & & & & & & 2 & 2 \\
\hline Tabellaria flocculosa (67004) & 7 & 9 & 5 & 11 & 6 & 7 & 8 \\
\hline \multicolumn{8}{|l|}{ Tabularia fasciculata (200002) } \\
\hline Tetracyclus glans (71006) & & & & 1 & & & 1 \\
\hline \multicolumn{8}{|l|}{ Tetracyclus lacustris (71003) } \\
\hline "Total chrysophyte cysts per slice & & 255 & & 70 & & 75 & 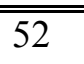 \\
\hline Total diatom counts per slice & 411 & 445 & 427 & 478 & 404 & 495 & 540 \\
\hline Total microspheres per slice & & 33 & & 15 & & 24 & 31 \\
\hline
\end{tabular}




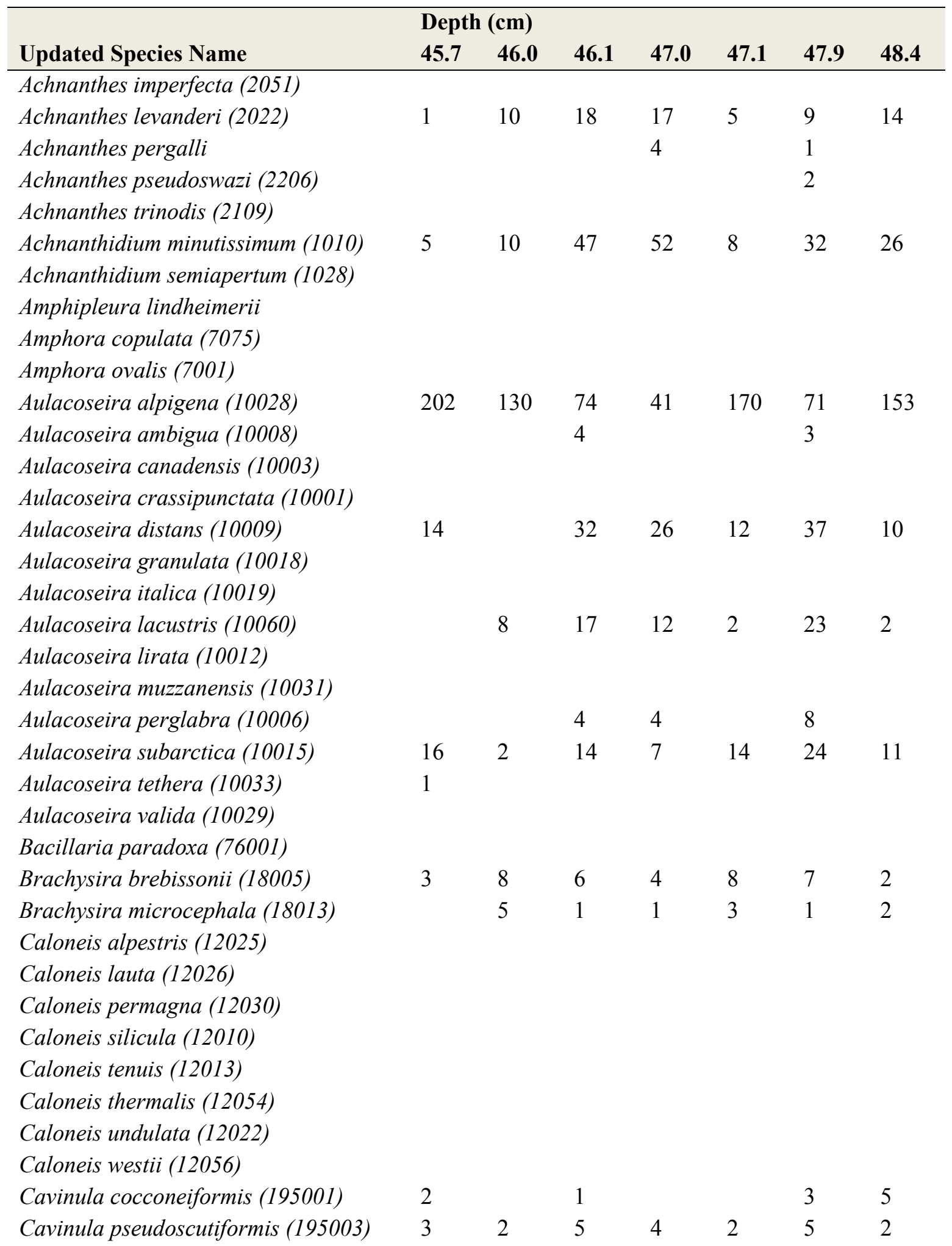




\begin{tabular}{|c|c|c|c|c|c|c|c|}
\hline \multirow[b]{2}{*}{ Updated Species Name } & \multicolumn{7}{|c|}{ Depth (cm) } \\
\hline & 45.7 & 46.0 & 46.1 & 47.0 & 47.1 & 47.9 & 48.4 \\
\hline \multicolumn{8}{|l|}{ Chamaepinnularia mediocris (212005) } \\
\hline Chamaepinnularia soehrensis (212006) & & & & 1 & & & \\
\hline \multicolumn{8}{|l|}{ Cocconeis placentula (16004) } \\
\hline \multicolumn{8}{|l|}{ Craticula halophila (21005) } \\
\hline \multicolumn{8}{|l|}{ Craticula riparia (21016) } \\
\hline Cyclotella comensis (20023) & & & 1 & & & & \\
\hline \multicolumn{8}{|l|}{ Cyclotella krammeri (20083) } \\
\hline Cyclotella ocellata (20009) & 25 & 30 & 23 & 31 & 28 & 28 & 34 \\
\hline Cyclotella rossii (20019) & 4 & 1 & & 1 & 1 & 2 & 1 \\
\hline Cyclotella tripartita (20085) & 17 & 5 & 8 & 9 & 8 & 5 & 7 \\
\hline \multicolumn{8}{|l|}{ Cymbella affinis (23073) } \\
\hline \multicolumn{8}{|l|}{ Cymbella amphicephala (23001) } \\
\hline \multicolumn{8}{|l|}{ Cymbella cesatii (23004) } \\
\hline \multicolumn{8}{|l|}{ Cymbella cistula (23005) } \\
\hline \multicolumn{8}{|l|}{ Cymbella helvetica (23099) } \\
\hline Cymbella heteropleura (23100) & & & 1 & & & & \\
\hline Cymbella lapponica (23116) & & & & & & 1 & \\
\hline \multicolumn{8}{|l|}{ Cymbella rupicola (23020) } \\
\hline \multicolumn{8}{|l|}{ Cymbella schimanskii } \\
\hline Cymbella sileiaca & & 2 & 5 & 2 & 6 & 3 & 2 \\
\hline \multicolumn{8}{|l|}{ Cymbella tumidula (23082) } \\
\hline \multicolumn{8}{|l|}{ Cymbella tynnii (47141) } \\
\hline \multicolumn{8}{|l|}{ Cymbopleura angustata (190013) } \\
\hline \multicolumn{8}{|l|}{ Cymbopleura cuspidata (190001) } \\
\hline \multicolumn{8}{|l|}{ Cymbopleura subaequalis (190017) } \\
\hline \multicolumn{8}{|l|}{ Denticula elegans (25001) } \\
\hline \multicolumn{8}{|l|}{ Denticula keutzingii } \\
\hline \multicolumn{8}{|l|}{ Diatoma mesodon (27002) } \\
\hline \multicolumn{8}{|l|}{ Diatoma vulgaris (27013) } \\
\hline \multicolumn{8}{|l|}{ Diploneis boldtiana (30012) } \\
\hline \multicolumn{8}{|l|}{ Diploneis elliptica (30001) } \\
\hline \multicolumn{8}{|l|}{ Diploneis finnica (30002) } \\
\hline Diploneis marginestriata (30003) & & 3 & & & & & \\
\hline Diploneis ovalis (30009) & & & & & & & \\
\hline Diploneis parma (30014) & & & & & & & \\
\hline Discostella pseudostelligera (2506002) & 2 & 5 & 6 & 18 & 7 & 9 & 6 \\
\hline Discostella stelligera (2506003) & & & 4 & 1 & 2 & & 1 \\
\hline
\end{tabular}




\begin{tabular}{|c|c|c|c|c|c|c|c|}
\hline \multirow[b]{2}{*}{ Updated Species Name } & \multicolumn{7}{|c|}{ Depth (cm) } \\
\hline & 45.7 & 46.0 & 46.1 & 47.0 & 47.1 & 47.9 & 48.4 \\
\hline \multicolumn{8}{|l|}{ Encyonema elginense (110044) } \\
\hline Encyonema gaeumannii (110008) & & & 1 & & & & \\
\hline \multicolumn{8}{|l|}{ Encyonema neogracile (110045) } \\
\hline Encyonopsis descripta (203014) & & & & 2 & & 1 & \\
\hline Encyonopsis falaisensis (203007) & & & 1 & & & & \\
\hline \multicolumn{8}{|l|}{ Encyonopsis microcephala (203002) } \\
\hline Encyonopsis minuta (203011) & 5 & 2 & 1 & 1 & 3 & 2 & 3 \\
\hline \multicolumn{8}{|l|}{ Epithemia adnata (32003) } \\
\hline Epithemia smithii (32002) & & & 1 & & 1 & & \\
\hline \multicolumn{8}{|l|}{ Epithemia sorex (32006) } \\
\hline Eucocconeis flexella (187001) & & 2 & & & & & \\
\hline \multicolumn{8}{|l|}{ Eucocconeis laevis (187002) } \\
\hline Eunotia arcus (33001) & & & 1 & 1 & & & 1 \\
\hline \multicolumn{8}{|l|}{ Eunotia bigibba (33005) } \\
\hline Eunotia bilunaris (33185) & 1 & & & & & & \\
\hline \multicolumn{8}{|l|}{ Eunotia circumborealis (33210) } \\
\hline \multicolumn{8}{|l|}{ Eunotia denticulata (33011) } \\
\hline \multicolumn{8}{|l|}{ Eunotia exigua (33015) } \\
\hline Eunotia faba (33172) & 6 & 2 & & 2 & 3 & 1 & 3 \\
\hline Eunotia implicata (33168) & & & & & & 1 & \\
\hline Eunotia incisa (33026) & & & 3 & & & 2 & \\
\hline \multicolumn{8}{|l|}{ Eunotia minor (33183) } \\
\hline \multicolumn{8}{|l|}{ Eunotia monodon (33035) } \\
\hline \multicolumn{8}{|l|}{ Eunotia muscicola (33184) } \\
\hline \multicolumn{8}{|l|}{ Eunotia paludosa (33083) } \\
\hline \multicolumn{8}{|l|}{ Eunotia pectinalis (33039) } \\
\hline \multicolumn{8}{|l|}{ Eunotia praerupta (33045) } \\
\hline \multicolumn{8}{|l|}{ Eunotia rhomboidea (33051) } \\
\hline \multicolumn{8}{|l|}{ Eunotia rhynchocephala (33191) } \\
\hline \multicolumn{8}{|l|}{ Eunotia septentrionalis (33053) } \\
\hline \multicolumn{8}{|l|}{ Eunotia serra (33054) } \\
\hline \multicolumn{8}{|l|}{ Eunotia soleirolii (33056) } \\
\hline Fragilaria capucina (34006) & & & 2 & & & 1 & \\
\hline \multicolumn{8}{|l|}{ Fragilaria delicatissima } \\
\hline Frustulia krammeri (35039) & & 2 & 1 & 3 & 1 & 1 & 1 \\
\hline Gomphonema acuminatum (37001) & & & 2 & & & 1 & \\
\hline Gomphonema angustatum (37003) & 1 & 2 & & & 2 & & \\
\hline
\end{tabular}




\begin{tabular}{|c|c|c|c|c|c|c|c|}
\hline \multirow[b]{2}{*}{ Updated Species Name } & \multicolumn{7}{|c|}{ Depth (cm) } \\
\hline & 45.7 & 46.0 & 46.1 & 47.0 & 47.1 & 47.9 & 48.4 \\
\hline \multicolumn{8}{|l|}{ Gomphonema olivaceum (37065) } \\
\hline \multicolumn{8}{|l|}{ Gomphonema parvulum (37010) } \\
\hline \multicolumn{8}{|l|}{ Gomphonema pseudosphaerophorum } \\
\hline \multicolumn{8}{|l|}{ Gomphonema rhombicum (37080) } \\
\hline Gomphonema sarcophagus (37152) & & & 2 & & & & \\
\hline \multicolumn{8}{|l|}{ Gomphonema truncatum (37022) } \\
\hline Karayevia laterostrata (125002) & & & & & & 1 & \\
\hline \multicolumn{8}{|l|}{ Karayevia ploenensis (125008) } \\
\hline Karayevia suchlandtii (125009) & 4 & 1 & 1 & 5 & & 6 & 2 \\
\hline \multicolumn{8}{|l|}{ Navicula absoluta (46494) } \\
\hline Navicula cryptocephala (46014) & & 1 & 1 & & 1 & & 1 \\
\hline \multicolumn{8}{|l|}{ Navicula difficillima (46017) } \\
\hline \multicolumn{8}{|l|}{ Navicula levanderii } \\
\hline \multicolumn{8}{|l|}{ Navicula prominula } \\
\hline \multicolumn{8}{|l|}{ Navicula pseudobryophila (46807) } \\
\hline \multicolumn{8}{|l|}{ Navicula pseudoventralis (46166) } \\
\hline Navicula schmassmannii (46066) & 2 & 2 & 2 & 6 & & 3 & \\
\hline \multicolumn{8}{|l|}{ Navicula striolata (93266) } \\
\hline \multicolumn{8}{|l|}{ Navicula subrotundata (46079) } \\
\hline \multicolumn{8}{|l|}{ Navicula trivalis } \\
\hline \multicolumn{8}{|l|}{ Navicula viridula (46408) } \\
\hline \multicolumn{8}{|l|}{ Neidium affine (47001) } \\
\hline \multicolumn{8}{|l|}{ Neidium ampliatum (47066) } \\
\hline \multicolumn{8}{|l|}{ Neidium dubium (47011) } \\
\hline \multicolumn{8}{|l|}{ Neidium hitchcockii (47028) } \\
\hline \multicolumn{8}{|l|}{ Neidium iridis (47014) } \\
\hline \multicolumn{8}{|l|}{ Neidium septentrionalis (47110) } \\
\hline \multicolumn{8}{|l|}{ Nitzschia angustata (48093) } \\
\hline \multicolumn{8}{|l|}{ Nitzschia behrei (48585) } \\
\hline Nitzschia diversa (48411) & & & & & & & \\
\hline Nitzschia elegans (48010) & & & & & & & \\
\hline Nitzschia fonticola (48011) & 8 & & 14 & 17 & 7 & 11 & 7 \\
\hline Nitzschia gisela (48624) & & & & & & & \\
\hline Nitzschia graciliformis (48119) & & & & & & & \\
\hline Nitzschia gracilis (48015) & & & & & & & \\
\hline Nitzschia recta (48029) & & & & & & & \\
\hline Nitzschia tropica (48045) & & & & & & & \\
\hline
\end{tabular}




\begin{tabular}{|c|c|c|c|c|c|c|c|}
\hline \multirow[b]{2}{*}{ Updated Species Name } & \multicolumn{2}{|c|}{ Depth (cm) } & \multirow[b]{2}{*}{46.1} & \multirow[b]{2}{*}{47.0} & \multirow[b]{2}{*}{47.1} & \multirow[b]{2}{*}{47.9} & \multirow[b]{2}{*}{48.4} \\
\hline & 45.7 & 46.0 & & & & & \\
\hline \multicolumn{8}{|l|}{ Nupela gracillima (92026) } \\
\hline \multicolumn{8}{|l|}{ Oxyneis binalis (9107001) } \\
\hline \multicolumn{8}{|l|}{ Pinnularia alpina (52807) } \\
\hline \multicolumn{8}{|l|}{ Pinnularia appendiculata (52009) } \\
\hline \multicolumn{8}{|l|}{ Pinnularia borealis (52013) } \\
\hline \multicolumn{8}{|l|}{ Pinnularia brauniana (103001) } \\
\hline \multicolumn{8}{|l|}{ Pinnularia divergens (52025) } \\
\hline \multicolumn{8}{|l|}{ Pinnularia episcopalis } \\
\hline \multicolumn{8}{|l|}{ Pinnularia gibba (52159) } \\
\hline \multicolumn{8}{|l|}{ Pinnularia interrupta (52194) } \\
\hline \multicolumn{8}{|l|}{ Pinnularia karelica } \\
\hline \multicolumn{8}{|l|}{ Pinnularia microstauron (52045) } \\
\hline \multicolumn{8}{|l|}{ Pinnularia nobilis (103038) } \\
\hline \multicolumn{8}{|l|}{ Pinnularia nodosa (52048) } \\
\hline \multicolumn{8}{|l|}{ Pinnularia polyonca (52087) } \\
\hline \multicolumn{8}{|l|}{ Pinnularia polyonca (52087) } \\
\hline \multicolumn{8}{|l|}{ Pinnularia pulchra (52801) } \\
\hline Pinnularia subcapitata (52059) & & & & 1 & & 2 & \\
\hline \multicolumn{8}{|l|}{ Pinnularia subrostrata (52184) } \\
\hline \multicolumn{8}{|l|}{ Pinnularia superdiverdentissima } \\
\hline Pinnularia viridis (52071) & & & 1 & 1 & & & \\
\hline Placoneis elginensis (194005) & & & & & & & \\
\hline Planothidium joursacense (155016) & & & 1 & & & & \\
\hline Planothidium oestrupii (155026) & & & 1 & & & & \\
\hline Platessa holsatica (2508002) & & & & 2 & & & \\
\hline Psammothidium curtissimum (186021) & & & 3 & 7 & & 3 & 0 \\
\hline Psammothidium didymum (186012) & & & & 2 & & 2 & \\
\hline Psammothidium helveticum (186003) & & & & & & & \\
\hline Psammothidium ventralis (186009) & & & & & & & \\
\hline Pseudostaurosira brevistriata (73001) & 42 & 41 & 33 & 38 & 36 & 29 & 31 \\
\hline Pseudostaurosira elliptica (73025) & & & 6 & 6 & & & \\
\hline Pseudostaurosira pseudoconstruens (73002) & 12 & 11 & 19 & 21 & 5 & 18 & 8 \\
\hline Puncticulata bodanica (208004) & 5 & 3 & 1 & 3 & 6 & 3 & 3 \\
\hline Reimeria sinuata (55002) & & & & & & & \\
\hline Rossithidium nodosum (189006) & & & 3 & 8 & & 3 & \\
\hline Rossithidium pusillum (189003) & 5 & 12 & 14 & 3 & 8 & 6 & 3 \\
\hline Sellaphora pupula (170006) & 1 & 7 & 2 & 1 & 1 & 1 & 3 \\
\hline
\end{tabular}




\begin{tabular}{|c|c|c|c|c|c|c|c|}
\hline \multirow[b]{2}{*}{ Updated Species Name } & \multicolumn{7}{|c|}{ Depth (cm) } \\
\hline & 45.7 & 46.0 & 46.1 & 47.0 & 47.1 & 47.9 & 48.4 \\
\hline \multicolumn{8}{|l|}{ Stauroneis acuta (62036) } \\
\hline \multicolumn{8}{|l|}{ Stauroneis anceps (62002) } \\
\hline \multicolumn{8}{|l|}{ Stauroneis cf. javanica (62045) } \\
\hline \multicolumn{8}{|l|}{ Stauroneis cf. schimanskii (62127) } \\
\hline \multicolumn{8}{|l|}{ Stauroneis phoenicenteron (62015) } \\
\hline Stauroneis producta (62017) & 2 & & & & & & 2 \\
\hline Stauroneis prominula (62069) & & & 2 & 1 & & 2 & \\
\hline \multicolumn{8}{|l|}{ Stauroneis thermicola (62040) } \\
\hline Staurosira construens (172001) & & & & & & 1 & \\
\hline Staurosira construens var. binodis (172005) & 7 & 10 & 5 & 5 & 4 & 1 & 8 \\
\hline Staurosira construens var. exigua (172022) & 24 & 32 & 27 & 29 & 34 & 24 & 31 \\
\hline Staurosira construens var. venter (172006) & 21 & 40 & 38 & 36 & 20 & 21 & 51 \\
\hline \multicolumn{8}{|l|}{ Staurosirella lapponica (175002) } \\
\hline $\begin{array}{l}\text { Staurosirella leptostauron var. rhomboides } \\
\text { (175017) }\end{array}$ & & 2 & 1 & 3 & 1 & 1 & 1 \\
\hline Staurosirella pinnata (175005) & 7 & 10 & 16 & 18 & 7 & 35 & 11 \\
\hline \multicolumn{8}{|l|}{ Stenopterobia anceps (63003) } \\
\hline \multicolumn{8}{|l|}{ Stenopterobia delicatissima (63007) } \\
\hline \multicolumn{8}{|l|}{ Surirella amphioxys (65069) } \\
\hline \multicolumn{8}{|l|}{ Surirella angusta (65002) } \\
\hline \multicolumn{8}{|l|}{ Surirella elegans (65072) } \\
\hline \multicolumn{8}{|l|}{ Surirella gracilis (65013) } \\
\hline \multicolumn{8}{|l|}{ Surirella linearis (65014) } \\
\hline Tabellaria fenestrata (67002) & 1 & & 2 & & 5 & 1 & \\
\hline Tabellaria flocculosa (67004) & 3 & 4 & 9 & 9 & & 4 & 6 \\
\hline \multicolumn{8}{|l|}{ Tabularia fasciculata (200002) } \\
\hline Tetracyclus glans (71006) & & & 1 & & & 1 & \\
\hline Tetracyclus lacustris (71003) & & & & & & 1 & \\
\hline Total chrysophyte cysts per slice & & & 80 & 67 & & 47 & \\
\hline Total diatom counts per slice & 452 & 407 & 489 & 466 & 421 & 465 & 454 \\
\hline Total microspheres per slice & & & 23 & 13 & & 9 & \\
\hline
\end{tabular}




\begin{tabular}{|c|c|c|c|c|c|c|c|}
\hline \multirow[b]{2}{*}{ Updated Species Name } & \multicolumn{7}{|c|}{ Depth (cm) } \\
\hline & 48.8 & 49.5 & 49.7 & 49.9 & 50.6 & 51.4 & 51.7 \\
\hline \multicolumn{8}{|l|}{ Achnanthes imperfecta (2051) } \\
\hline Achnanthes levanderi (2022) & 24 & 5 & 19 & 3 & 17 & 6 & 4 \\
\hline Achnanthes pergalli & & & 1 & & & & \\
\hline Achnanthes pseudoswazi (2206) & 1 & & 2 & & 2 & & \\
\hline \multicolumn{8}{|l|}{ Achnanthes trinodis (2109) } \\
\hline Achnanthidium minutissimum (1010) & 32 & 13 & 43 & 36 & 49 & 17 & 33 \\
\hline Achnanthidium semiapertum (1028) & & & 1 & & & & \\
\hline \multicolumn{8}{|l|}{ Amphipleura lindheimerii } \\
\hline \multicolumn{8}{|l|}{ Amphora copulata (7075) } \\
\hline Amphora ovalis (7001) & & 1 & & 1 & & 1 & \\
\hline Aulacoseira alpigena (10028) & 71 & 151 & 53 & 96 & 72 & 142 & 85 \\
\hline Aulacoseira ambigua (10008) & & & 1 & & 1 & & 4 \\
\hline \multicolumn{8}{|l|}{ Aulacoseira canadensis (10003) } \\
\hline \multicolumn{8}{|l|}{ Aulacoseira crassipunctata (10001) } \\
\hline Aulacoseira distans (10009) & 9 & 10 & 11 & 25 & 18 & 8 & 18 \\
\hline \multicolumn{8}{|l|}{ Aulacoseira granulata (10018) } \\
\hline \multicolumn{8}{|l|}{ Aulacoseira italica (10019) } \\
\hline Aulacoseira lacustris (10060) & 21 & 2 & 10 & & 18 & 1 & 23 \\
\hline \multicolumn{8}{|l|}{ Aulacoseira lirata (10012) } \\
\hline \multicolumn{8}{|l|}{ Aulacoseira muzzanensis (10031) } \\
\hline Aulacoseira perglabra (10006) & 2 & & & 2 & 6 & & 6 \\
\hline Aulacoseira subarctica (10015) & 18 & 7 & 14 & 10 & 12 & 7 & 14 \\
\hline \multicolumn{8}{|l|}{ Aulacoseira tethera (10033) } \\
\hline Aulacoseira valida (10029) & 4 & & 2 & & 3 & & \\
\hline \multicolumn{8}{|l|}{ Bacillaria paradoxa (76001) } \\
\hline Brachysira brebissonii (18005) & 10 & 3 & 4 & 7 & 3 & 3 & 10 \\
\hline Brachysira microcephala (18013) & 1 & & 1 & 2 & 3 & & 12 \\
\hline \multicolumn{8}{|l|}{ Caloneis alpestris (12025) } \\
\hline \multicolumn{8}{|l|}{ Caloneis lauta (12026) } \\
\hline \multicolumn{8}{|l|}{ Caloneis permagna (12030) } \\
\hline \multicolumn{8}{|l|}{ Caloneis silicula (12010) } \\
\hline \multicolumn{8}{|l|}{ Caloneis tenuis (12013) } \\
\hline \multicolumn{8}{|l|}{ Caloneis thermalis (12054) } \\
\hline \multicolumn{8}{|l|}{ Caloneis undulata (12022) } \\
\hline \multicolumn{8}{|l|}{ Caloneis westii (12056) } \\
\hline Cavinula cocconeiformis (195001) & 3 & & 3 & 2 & 2 & 2 & 4 \\
\hline Cavinula pseudoscutiformis (195003) & 5 & 4 & 4 & 2 & 5 & 4 & 4 \\
\hline
\end{tabular}




\begin{tabular}{|c|c|c|c|c|c|c|c|}
\hline \multirow[b]{2}{*}{ Updated Species Name } & \multicolumn{7}{|c|}{ Depth (cm) } \\
\hline & 48.8 & 49.5 & 49.7 & 49.9 & 50.6 & 51.4 & $\mathbf{5 1 . 7}$ \\
\hline \multicolumn{8}{|l|}{ Chamaepinnularia mediocris (212005) } \\
\hline \multicolumn{8}{|l|}{ Chamaepinnularia soehrensis (212006) } \\
\hline \multicolumn{8}{|l|}{ Cocconeis placentula (16004) } \\
\hline Craticula halophila (21005) & 1 & & & & & & \\
\hline Craticula riparia (21016) & & & & & 1 & & \\
\hline Cyclotella comensis (20023) & & & & 1 & & & \\
\hline \multicolumn{8}{|l|}{ Cyclotella krammeri (20083) } \\
\hline Cyclotella ocellata (20009) & 16 & 32 & 16 & 21 & 10 & 42 & 23 \\
\hline Cyclotella rossii (20019) & 3 & & 12 & 3 & 2 & 3 & 1 \\
\hline Cyclotella tripartita (20085) & 18 & 2 & 17 & 21 & 9 & 12 & 12 \\
\hline \multicolumn{8}{|l|}{ Cymbella affinis (23073) } \\
\hline \multicolumn{8}{|l|}{ Cymbella amphicephala (23001) } \\
\hline \multicolumn{8}{|l|}{ Cymbella cesatii (23004) } \\
\hline \multicolumn{8}{|l|}{ Cymbella cistula (23005) } \\
\hline \multicolumn{8}{|l|}{ Cymbella helvetica (23099) } \\
\hline \multicolumn{8}{|l|}{ Cymbella heteropleura (23100) } \\
\hline \multicolumn{8}{|l|}{ Cymbella lapponica (23116) } \\
\hline \multicolumn{8}{|l|}{ Cymbella rupicola (23020) } \\
\hline \multicolumn{8}{|l|}{ Cymbella schimanskii } \\
\hline Cymbella sileiaca & 4 & 5 & 7 & 2 & 3 & 4 & 2 \\
\hline Cymbella tumidula (23082) & & & & & & & 1 \\
\hline \multicolumn{8}{|l|}{ Cymbella tynnii (47141) } \\
\hline \multicolumn{8}{|l|}{ Cymbopleura angustata (190013) } \\
\hline \multicolumn{8}{|l|}{ Cymbopleura cuspidata (190001) } \\
\hline \multicolumn{8}{|l|}{ Cymbopleura subaequalis (190017) } \\
\hline \multicolumn{8}{|l|}{ Denticula elegans (25001) } \\
\hline Denticula keutzingii & & & & & & & 2 \\
\hline \multicolumn{8}{|l|}{ Diatoma mesodon (27002) } \\
\hline \multicolumn{8}{|l|}{ Diatoma vulgaris (27013) } \\
\hline \multicolumn{8}{|l|}{ Diploneis boldtiana (30012) } \\
\hline \multicolumn{8}{|l|}{ Diploneis elliptica (30001) } \\
\hline \multicolumn{8}{|l|}{ Diploneis finnica (30002) } \\
\hline Diploneis marginestriata (30003) & & & & 1 & & & \\
\hline Diploneis ovalis (30009) & & 1 & & & & 1 & \\
\hline Diploneis parma (30014) & & & 1 & & & & \\
\hline Discostella pseudostelligera (2506002) & 10 & 8 & 17 & 15 & 11 & 8 & 12 \\
\hline Discostella stelligera (2506003) & 2 & & & & 2 & 3 & 1 \\
\hline
\end{tabular}




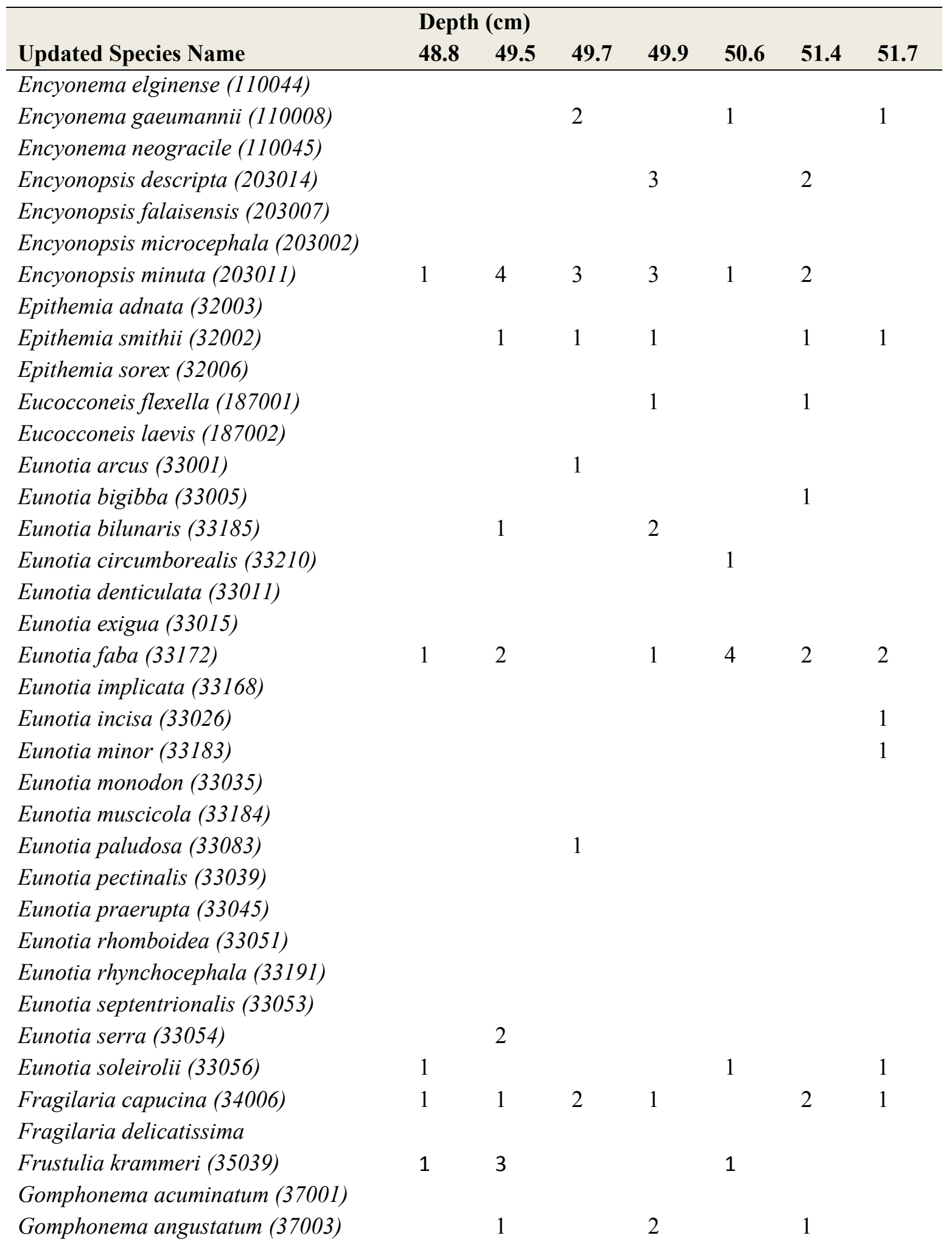




\begin{tabular}{|c|c|c|c|c|c|c|c|}
\hline & Deptl & (cm) & & & & & \\
\hline Updated Species Name & 48.8 & 49.5 & 49.7 & 49.9 & 50.6 & 51.4 & 51.7 \\
\hline Gomphonema olivaceum (37065) & & & & & & & \\
\hline Gomphonema parvulum (37010) & & & & & & & \\
\hline Gomphonema pseudosphaerophorum & & & & & & & \\
\hline Gomphonema rhombicum (37080) & & & & & & & \\
\hline Gomphonema sarcophagus (37152) & 3 & & 2 & & & & 1 \\
\hline Gomphonema truncatum (37022) & & & & & & & \\
\hline Karayevia laterostrata (125002) & & & 1 & 1 & & & \\
\hline Karayevia ploenensis (125008) & & & & & & & \\
\hline Karayevia suchlandtii (125009) & 8 & 6 & 5 & 17 & 6 & 2 & 13 \\
\hline Navicula absoluta (46494) & & & & & & & \\
\hline Navicula cryptocephala (46014) & & 1 & 1 & 1 & 2 & 3 & \\
\hline Navicula difficillima (46017) & & & & & & & \\
\hline Navicula levanderii & & & & & & & \\
\hline Navicula prominula & & & & & & & \\
\hline Navicula pseudobryophila (46807) & & & & & & & \\
\hline Navicula pseudoventralis (46166) & & & 1 & & & & \\
\hline Navicula schmassmannii (46066) & 2 & 3 & 5 & 5 & 2 & 3 & 3 \\
\hline Navicula striolata (93266) & & & & & & & \\
\hline Navicula subrotundata (46079) & & & & & & & \\
\hline Navicula trivalis & & & & & & & \\
\hline Navicula viridula (46408) & & & & & & & \\
\hline Neidium affine (47001) & & & & & & & \\
\hline Neidium ampliatum (47066) & & & & & & & \\
\hline Neidium dubium (47011) & & 1 & & & & & \\
\hline Neidium hitchcockii (47028) & & & 1 & & & & \\
\hline Neidium iridis (47014) & & & & & & & \\
\hline Neidium septentrionalis (47110) & & & & & & & \\
\hline Nitzschia angustata (48093) & & & & & & & \\
\hline Nitzschia behrei (48585) & & & & & & & \\
\hline Nitzschia diversa (48411) & & & & & & & \\
\hline Nitzschia elegans (48010) & & & & & & & \\
\hline Nitzschia fonticola (48011) & 12 & 8 & 11 & 7 & 5 & 4 & 6 \\
\hline Nitzschia gisela (48624) & 1 & & & & & & \\
\hline Nitzschia graciliformis (48119) & & & & & & & \\
\hline Nitzschia gracilis (48015) & & & & & & & \\
\hline Nitzschia recta (48029) & & & & & & & \\
\hline Nitzschia tropica (48045) & & & & & & & \\
\hline
\end{tabular}




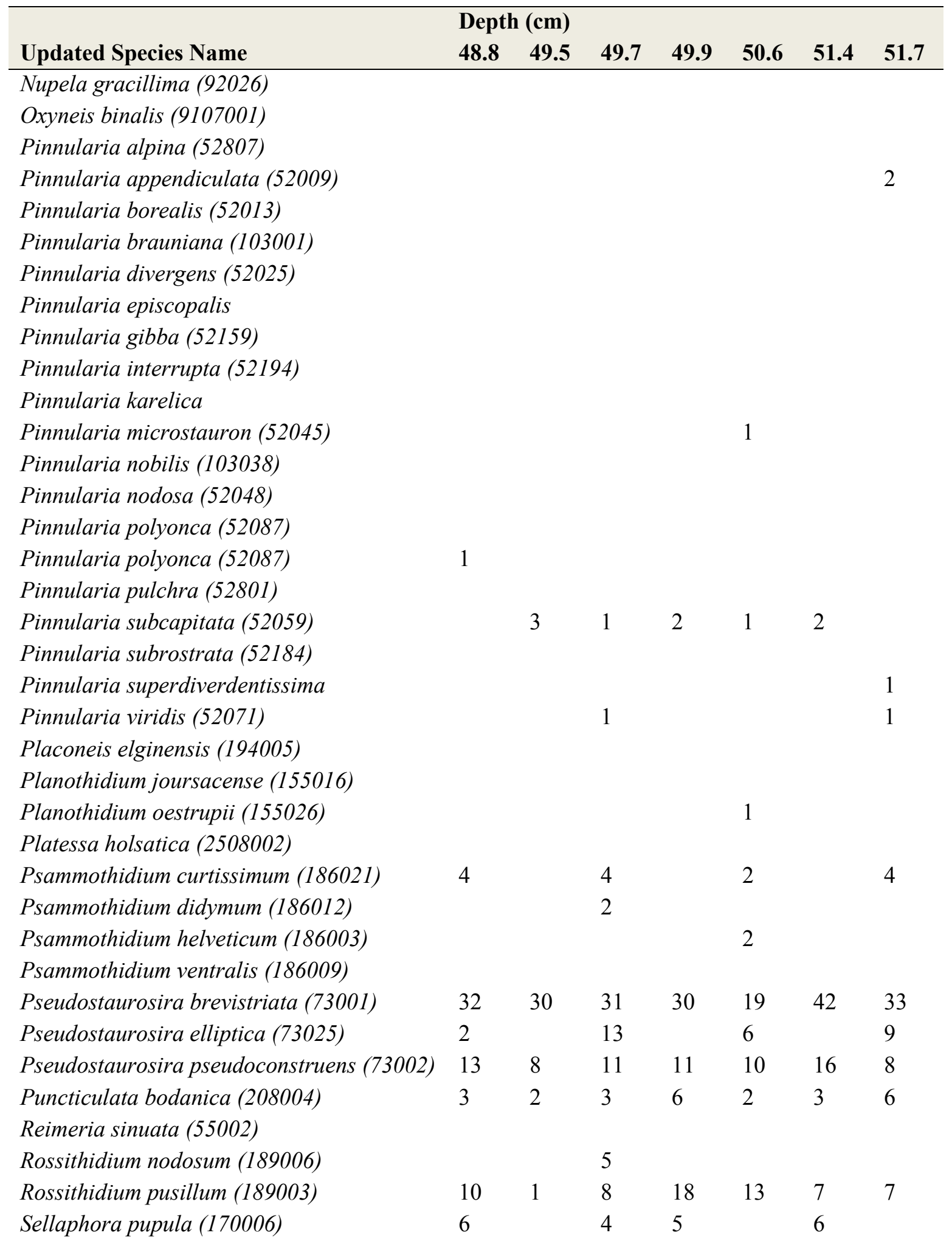


Updated Species Name

$\begin{array}{lllllll}48.8 & 49.5 & 49.7 & 49.9 & 50.6 & 51.4 & 51.7\end{array}$

Stauroneis acuta (62036)

Stauroneis anceps (62002)

Stauroneis cf. javanica (62045)

Stauroneis cf. schimanskii (62127)

Stauroneis phoenicenteron (62015)

3

2

Stauroneis producta (62017)

Stauroneis prominula (62069)

Stauroneis thermicola (62040)

Staurosira construens (172001)

Staurosira construens var. binodis (172005)

Staurosira construens var. exigua (172022)

$\begin{array}{llllll}5 & 6 & 6 & 8 & 7 & 3\end{array}$

Staurosira construens var. venter (172006)

$\begin{array}{lllllll}31 & 26 & 25 & 33 & 27 & 30 & 15\end{array}$

Staurosirella lapponica (175002)

$\begin{array}{lllllll}44 & 28 & 41 & 22 & 29 & 31 & 40\end{array}$

Staurosirella leptostauron var. rhomboides (175017) 143

Staurosirella pinnata (175005)

$\begin{array}{lllllll}23 & 11 & 35 & 14 & 17 & 7 & 15\end{array}$

Stenopterobia anceps (63003)

Stenopterobia delicatissima (63007)

Surirella amphioxys (65069)

Surirella angusta (65002)

Surirella elegans (65072)

Surirella gracilis (65013)

Surirella linearis (65014)

Tabellaria fenestrata (67002)

Tabellaria flocculosa (67004)

Tabularia fasciculata (200002)

Tetracyclus glans (71006)

$5 \quad 6$

Tetracyclus lacustris (71003)

\begin{tabular}{|c|c|c|c|c|c|c|c|}
\hline "Total chrysophyte cysts per slice & 23 & & 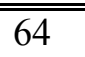 & & 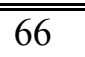 & & 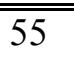 \\
\hline Total diatom counts per slice & 475 & 403 & 477 & 445 & 430 & 444 & 474 \\
\hline Total microspheres per slice & 31 & & 20 & & 31 & & 17 \\
\hline
\end{tabular}




\begin{tabular}{|c|c|c|c|c|c|c|c|c|}
\hline \multirow[b]{2}{*}{ Updated Species Name } & \multicolumn{8}{|c|}{ Depth (cm) } \\
\hline & 52.6 & 52.9 & 53.6 & 54.1 & 54.7 & 55.3 & 55.8 & 56.3 \\
\hline \multicolumn{9}{|l|}{ Achnanthes imperfecta (2051) } \\
\hline Achnanthes levanderi (2022) & 7 & 18 & 8 & 14 & 8 & 6 & 7 & 9 \\
\hline Achnanthes pergalli & & 1 & & & & & & \\
\hline Achnanthes pseudoswazi (2206) & 1 & & & & & & & \\
\hline Achnanthes trinodis (2109) & & & & & & 1 & & \\
\hline Achnanthidium minutissimum (1010) & 15 & 51 & 36 & 42 & 14 & 35 & 13 & 51 \\
\hline \multicolumn{9}{|l|}{ Achnanthidium semiapertum (1028) } \\
\hline \multicolumn{9}{|l|}{ Amphipleura lindheimerii } \\
\hline \multicolumn{9}{|l|}{ Amphora copulata (7075) } \\
\hline Amphora ovalis (7001) & 1 & & & & & & & \\
\hline Aulacoseira alpigena (10028) & 139 & 42 & 90 & 63 & 148 & 55 & 142 & 70 \\
\hline Aulacoseira ambigua (10008) & & & & & & & & 2 \\
\hline \multicolumn{9}{|l|}{ Aulacoseira canadensis (10003) } \\
\hline \multicolumn{9}{|l|}{ Aulacoseira crassipunctata (10001) } \\
\hline Aulacoseira distans (10009) & 12 & 20 & 8 & 35 & 15 & 48 & 6 & 40 \\
\hline Aulacoseira granulata (10018) & & & 2 & 1 & & 3 & & \\
\hline \multicolumn{9}{|l|}{ Aulacoseira italica (10019) } \\
\hline Aulacoseira lacustris (10060) & & 8 & & 11 & & 20 & & 13 \\
\hline \multicolumn{9}{|l|}{ Aulacoseira lirata (10012) } \\
\hline \multicolumn{9}{|l|}{ Aulacoseira muzzanensis (10031) } \\
\hline Aulacoseira perglabra (10006) & & 2 & & 4 & & 12 & & 7 \\
\hline Aulacoseira subarctica (10015) & 12 & 7 & 6 & 1 & 12 & & 12 & \\
\hline Aulacoseira tethera (10033) & 1 & & & & & & & \\
\hline Aulacoseira valida (10029) & & & & & & 1 & & \\
\hline \multicolumn{9}{|l|}{ Bacillaria paradoxa (76001) } \\
\hline Brachysira brebissonii (18005) & 8 & 8 & 3 & & 4 & 4 & 4 & 3 \\
\hline Brachysira microcephala (18013) & 1 & 8 & 1 & 9 & 1 & 5 & & 4 \\
\hline \multicolumn{9}{|l|}{ Caloneis alpestris (12025) } \\
\hline \multicolumn{9}{|l|}{ Caloneis lauta (12026) } \\
\hline \multicolumn{9}{|l|}{ Caloneis permagna (12030) } \\
\hline \multicolumn{9}{|l|}{ Caloneis silicula (12010) } \\
\hline \multicolumn{9}{|l|}{ Caloneis tenuis (12013) } \\
\hline Caloneis thermalis (12054) & & 1 & & & & & & \\
\hline \multicolumn{9}{|l|}{ Caloneis undulata (12022) } \\
\hline \multicolumn{9}{|l|}{ Caloneis westii (12056) } \\
\hline Cavinula cocconeiformis (195001) & 1 & 6 & 3 & 4 & 1 & 3 & & 2 \\
\hline Cavinula pseudoscutiformis (195003) & 2 & 7 & 1 & 1 & 1 & 4 & 6 & 4 \\
\hline
\end{tabular}




\begin{tabular}{|c|c|c|c|c|c|c|c|c|}
\hline \multirow[b]{2}{*}{ Updated Species Name } & \multicolumn{8}{|c|}{ Depth (cm) } \\
\hline & 52.6 & 52.9 & 53.6 & 54.1 & 54.7 & 55.3 & 55.8 & 56.3 \\
\hline \multicolumn{9}{|l|}{ Chamaepinnularia mediocris (212005) } \\
\hline \multicolumn{9}{|l|}{ Chamaepinnularia soehrensis (212006) } \\
\hline \multicolumn{9}{|l|}{ Cocconeis placentula (16004) } \\
\hline Craticula halophila (21005) & & & & & 1 & & & \\
\hline \multicolumn{9}{|l|}{ Craticula riparia (21016) } \\
\hline Cyclotella comensis (20023) & 2 & & & & & & & \\
\hline \multicolumn{9}{|l|}{ Cyclotella krammeri (20083) } \\
\hline Cyclotella ocellata (20009) & 33 & 21 & 35 & 32 & 52 & 33 & 30 & 20 \\
\hline Cyclotella rossii (20019) & 1 & 2 & 2 & & 1 & 1 & & 2 \\
\hline Cyclotella tripartita (20085) & 7 & 13 & 15 & 17 & 9 & 24 & 6 & 21 \\
\hline \multicolumn{9}{|l|}{ Cymbella affinis (23073) } \\
\hline \multicolumn{9}{|l|}{ Cymbella amphicephala (23001) } \\
\hline Cymbella cesatii (23004) & & & & & & 1 & & \\
\hline \multicolumn{9}{|l|}{ Cymbella cistula (23005) } \\
\hline \multicolumn{9}{|l|}{ Cymbella helvetica (23099) } \\
\hline \multicolumn{9}{|l|}{ Cymbella heteropleura (23100) } \\
\hline \multicolumn{9}{|l|}{ Cymbella lapponica (23116) } \\
\hline \multicolumn{9}{|l|}{ Cymbella rupicola (23020) } \\
\hline \multicolumn{9}{|l|}{ Cymbella schimanskii } \\
\hline Cymbella sileiaca & 8 & 3 & 2 & 2 & & & 2 & 1 \\
\hline \multicolumn{9}{|l|}{ Cymbella tumidula (23082) } \\
\hline \multicolumn{9}{|l|}{ Cymbella tynnii (47141) } \\
\hline \multicolumn{9}{|l|}{ Cymbopleura angustata (190013) } \\
\hline Cymbopleura cuspidata (190001) & & & & & & & & 1 \\
\hline Cymbopleura subaequalis (190017) & & & & & & & & 1 \\
\hline \multicolumn{9}{|l|}{ Denticula elegans (25001) } \\
\hline Denticula keutzingii & & 1 & & & & & & \\
\hline Diatoma mesodon (27002) & & & & & & 1 & & \\
\hline \multicolumn{9}{|l|}{ Diatoma vulgaris (27013) } \\
\hline \multicolumn{9}{|l|}{ Diploneis boldtiana (30012) } \\
\hline \multicolumn{9}{|l|}{ Diploneis elliptica (30001) } \\
\hline Diploneis finnica (30002) & & & & & & 1 & & \\
\hline Diploneis marginestriata (30003) & & 1 & & & 1 & 1 & 1 & \\
\hline Diploneis ovalis (30009) & & & & & & & 1 & \\
\hline Diploneis parma (30014) & & 1 & & & & & & \\
\hline Discostella pseudostelligera (2506002) & 7 & 9 & 12 & 6 & 9 & 10 & 6 & 7 \\
\hline Discostella stelligera (2506003) & 3 & 1 & 5 & & 2 & 1 & & \\
\hline
\end{tabular}




\begin{tabular}{|c|c|c|c|c|c|c|c|c|}
\hline \multirow[b]{2}{*}{ Updated Species Name } & \multicolumn{2}{|c|}{ Depth (cm) } & \multirow[b]{2}{*}{53.6} & \multirow[b]{2}{*}{54.1} & \multirow[b]{2}{*}{54.7} & \multirow[b]{2}{*}{55.3} & \multirow[b]{2}{*}{55.8} & \multirow[b]{2}{*}{56.3} \\
\hline & 52.6 & 52.9 & & & & & & \\
\hline \multicolumn{9}{|l|}{ Encyonema elginense (110044) } \\
\hline Encyonema gaeumannii (110008) & & & & & & & & 3 \\
\hline Encyonema neogracile (110045) & & & & & & 1 & & \\
\hline Encyonopsis descripta (203014) & 1 & & & & & 3 & 3 & \\
\hline \multicolumn{9}{|l|}{ Encyonopsis falaisensis (203007) } \\
\hline Encyonopsis microcephala (203002) & & 1 & & & & 1 & & \\
\hline Encyonopsis minuta (203011) & 6 & 1 & 2 & & 4 & 3 & 3 & 1 \\
\hline \multicolumn{9}{|l|}{ Epithemia adnata (32003) } \\
\hline Epithemia smithii (32002) & 1 & & & & 1 & 1 & & \\
\hline Epithemia sorex (32006) & & & & & & & & 1 \\
\hline Eucocconeis flexella (187001) & 1 & & & & & & 1 & \\
\hline \multicolumn{9}{|l|}{ Eucocconeis laevis (187002) } \\
\hline Eunotia arcus (33001) & & & 1 & & & & & 2 \\
\hline Eunotia bigibba (33005) & 1 & & & & & 1 & & 2 \\
\hline Eunotia bilunaris (33185) & & 1 & & & & & & \\
\hline \multicolumn{9}{|l|}{ Eunotia circumborealis (33210) } \\
\hline \multicolumn{9}{|l|}{ Eunotia denticulata (33011) } \\
\hline \multicolumn{9}{|l|}{ Eunotia exigua (33015) } \\
\hline Eunotia faba (33172) & 4 & & 4 & & 2 & & 3 & 1 \\
\hline Eunotia implicata (33168) & & & & & & 3 & & \\
\hline \multicolumn{9}{|l|}{ Eunotia incisa (33026) } \\
\hline \multicolumn{9}{|l|}{ Eunotia minor (33183) } \\
\hline \multicolumn{9}{|l|}{ Eunotia monodon (33035) } \\
\hline \multicolumn{9}{|l|}{ Eunotia muscicola (33184) } \\
\hline \multicolumn{9}{|l|}{ Eunotia paludosa (33083) } \\
\hline Eunotia pectinalis (33039) & & & & & & 1 & & \\
\hline \multicolumn{9}{|l|}{ Eunotia praerupta (33045) } \\
\hline \multicolumn{9}{|l|}{ Eunotia rhomboidea (33051) } \\
\hline \multicolumn{9}{|l|}{ Eunotia rhynchocephala (33191) } \\
\hline Eunotia septentrionalis (33053) & & 1 & & & & & & \\
\hline \multicolumn{9}{|l|}{ Eunotia serra (33054) } \\
\hline \multicolumn{9}{|l|}{ Eunotia soleirolii (33056) } \\
\hline Fragilaria capucina (34006) & 2 & 1 & 1 & & 3 & 3 & 2 & \\
\hline Fragilaria delicatissima & & & & & & & & \\
\hline Frustulia krammeri (35039) & 1 & 1 & & & & 3 & & \\
\hline Gomphonema acuminatum (37001) & & 1 & & & & & & 1 \\
\hline Gomphonema angustatum (37003) & & 1 & & & 1 & 1 & & 2 \\
\hline
\end{tabular}




\begin{tabular}{|c|c|c|c|c|c|c|c|c|}
\hline \multirow[b]{2}{*}{ Updated Species Name } & \multicolumn{8}{|c|}{ Depth (cm) } \\
\hline & 52.6 & 52.9 & 53.6 & 54.1 & 54.7 & 55.3 & 55.8 & 56.3 \\
\hline \multicolumn{9}{|l|}{ Gomphonema olivaceum (37065) } \\
\hline \multicolumn{9}{|l|}{ Gomphonema parvulum (37010) } \\
\hline \multicolumn{9}{|l|}{ Gomphonema pseudosphaerophorum } \\
\hline \multicolumn{9}{|l|}{ Gomphonema rhombicum (37080) } \\
\hline \multicolumn{9}{|l|}{ Gomphonema sarcophagus (37152) } \\
\hline \multicolumn{9}{|l|}{ Gomphonema truncatum (37022) } \\
\hline \multicolumn{9}{|l|}{ Karayevia laterostrata (125002) } \\
\hline \multicolumn{9}{|l|}{ Karayevia ploenensis (125008) } \\
\hline Karayevia suchlandtii (125009) & 4 & 9 & 6 & 12 & 2 & 11 & 7 & 9 \\
\hline Navicula absoluta (46494) & & 1 & & & & & & \\
\hline Navicula cryptocephala (46014) & 1 & 1 & 1 & 1 & 1 & & 2 & \\
\hline \multicolumn{9}{|l|}{ Navicula difficillima (46017) } \\
\hline \multicolumn{9}{|l|}{ Navicula levanderii } \\
\hline \multicolumn{9}{|l|}{ Navicula prominula } \\
\hline Navicula pseudobryophila (46807) & & & & 1 & & & & \\
\hline \multicolumn{9}{|l|}{ Navicula pseudoventralis (46166) } \\
\hline Navicula schmassmannii (46066) & & & 7 & 2 & 1 & 3 & & 4 \\
\hline \multicolumn{9}{|l|}{ Navicula striolata (93266) } \\
\hline \multicolumn{9}{|l|}{ Navicula subrotundata (46079) } \\
\hline \multicolumn{9}{|l|}{ Navicula trivalis } \\
\hline \multicolumn{9}{|l|}{ Navicula viridula (46408) } \\
\hline \multicolumn{9}{|l|}{ Neidium affine (47001) } \\
\hline \multicolumn{9}{|l|}{ Neidium ampliatum (47066) } \\
\hline \multicolumn{9}{|l|}{ Neidium dubium (47011) } \\
\hline \multicolumn{9}{|l|}{ Neidium hitchcockii (47028) } \\
\hline \multicolumn{9}{|l|}{ Neidium iridis (47014) } \\
\hline \multicolumn{9}{|l|}{ Neidium septentrionalis (47110) } \\
\hline \multicolumn{9}{|l|}{ Nitzschia angustata (48093) } \\
\hline Nitzschia behrei (48585) & & & & & & & & \\
\hline Nitzschia diversa (48411) & & & & & & & & 1 \\
\hline Nitzschia elegans (48010) & & & & & & & & \\
\hline Nitzschia fonticola (48011) & 5 & 17 & 10 & 8 & 11 & 4 & 12 & 2 \\
\hline Nitzschia gisela (48624) & & & & & & & & \\
\hline Nitzschia graciliformis (48119) & & & & & & & & \\
\hline Nitzschia gracilis (48015) & & & & & & & & \\
\hline Nitzschia recta (48029) & & & & & & & & \\
\hline Nitzschia tropica (48045) & & & & & & & & \\
\hline
\end{tabular}




\begin{tabular}{|c|c|c|c|c|c|c|c|c|}
\hline \multirow[b]{2}{*}{ Updated Species Name } & \multicolumn{8}{|c|}{ Depth (cm) } \\
\hline & 52.6 & 52.9 & 53.6 & 54.1 & 54.7 & 55.3 & 55.8 & 56.3 \\
\hline \multicolumn{9}{|l|}{ Nupela gracillima (92026) } \\
\hline \multicolumn{9}{|l|}{ Oxyneis binalis (9107001) } \\
\hline \multicolumn{9}{|l|}{ Pinnularia alpina (52807) } \\
\hline Pinnularia appendiculata (52009) & & & & & & 1 & & \\
\hline \multicolumn{9}{|l|}{ Pinnularia borealis (52013) } \\
\hline \multicolumn{9}{|l|}{ Pinnularia brauniana (103001) } \\
\hline \multicolumn{9}{|l|}{ Pinnularia divergens (52025) } \\
\hline \multicolumn{9}{|l|}{ Pinnularia episcopalis } \\
\hline \multicolumn{9}{|l|}{ Pinnularia gibba (52159) } \\
\hline Pinnularia interrupta (52194) & & & & & & & 1 & \\
\hline Pinnularia karelica & & 1 & & & & & & \\
\hline Pinnularia microstauron (52045) & & & & & & 1 & & \\
\hline \multicolumn{9}{|l|}{ Pinnularia nobilis (103038) } \\
\hline \multicolumn{9}{|l|}{ Pinnularia nodosa (52048) } \\
\hline \multicolumn{9}{|l|}{ Pinnularia polyonca (52087) } \\
\hline \multicolumn{9}{|l|}{ Pinnularia polyonca (52087) } \\
\hline \multicolumn{9}{|l|}{ Pinnularia pulchra (52801) } \\
\hline Pinnularia subcapitata (52059) & 1 & & & & 1 & & & \\
\hline \multicolumn{9}{|l|}{ Pinnularia subrostrata (52184) } \\
\hline \multicolumn{9}{|l|}{ Pinnularia superdiverdentissima } \\
\hline Pinnularia viridis (52071) & 1 & & & & & 3 & & \\
\hline \multicolumn{9}{|l|}{ Placoneis elginensis (194005) } \\
\hline \multicolumn{9}{|l|}{ Planothidium joursacense (155016) } \\
\hline \multicolumn{9}{|l|}{ Planothidium oestrupii (155026) } \\
\hline \multicolumn{9}{|l|}{ Platessa holsatica (2508002) } \\
\hline Psammothidium curtissimum (186021) & 1 & 4 & 1 & 4 & 1 & 0 & 1 & 4 \\
\hline Psammothidium didymum (186012) & & & & & & & 1 & \\
\hline \multicolumn{9}{|l|}{ Psammothidium helveticum (186003) } \\
\hline Psammothidium ventralis (186009) & & & & 1 & & & & \\
\hline Pseudostaurosira brevistriata (73001) & 19 & 38 & 32 & 24 & 38 & 41 & 28 & 41 \\
\hline Pseudostaurosira elliptica (73025) & & 2 & & 2 & & 3 & & 9 \\
\hline Pseudostaurosira pseudoconstruens (73002) & 8 & 5 & 10 & 14 & 11 & 20 & 8 & 21 \\
\hline Puncticulata bodanica (208004) & 4 & 5 & 1 & 3 & 7 & 8 & 1 & 4 \\
\hline \multicolumn{9}{|l|}{ Reimeria sinuata (55002) } \\
\hline Rossithidium nodosum (189006) & & 9 & & 1 & & 1 & & 2 \\
\hline Rossithidium pusillum (189003) & 8 & 11 & 11 & 6 & 5 & 6 & 8 & 8 \\
\hline Sellaphora pupula (170006) & 3 & & 1 & & 2 & 1 & 1 & 2 \\
\hline
\end{tabular}




\begin{tabular}{|c|c|c|c|c|c|c|c|c|}
\hline \multirow[b]{2}{*}{ Updated Species Name } & \multicolumn{8}{|c|}{ Depth (cm) } \\
\hline & 52.6 & 52.9 & 53.6 & 54.1 & 54.7 & 55.3 & 55.8 & 56.3 \\
\hline \multicolumn{9}{|l|}{ Stauroneis acuta (62036) } \\
\hline \multicolumn{9}{|l|}{ Stauroneis anceps (62002) } \\
\hline \multicolumn{9}{|l|}{ Stauroneis cf. javanica (62045) } \\
\hline \multicolumn{9}{|l|}{ Stauroneis cf. schimanskii (62127) } \\
\hline Stauroneis phoenicenteron (62015) & & & & 1 & & & & \\
\hline Stauroneis producta (62017) & 2 & & 1 & & 3 & & 1 & \\
\hline \multicolumn{9}{|l|}{ Stauroneis prominula (62069) } \\
\hline \multicolumn{9}{|l|}{ Stauroneis thermicola (62040) } \\
\hline Staurosira construens (172001) & & 8 & & & & & & \\
\hline Staurosira construens var. binodis (172005) & 4 & 8 & 11 & 4 & 4 & 8 & 7 & 10 \\
\hline Staurosira construens var. exigua (172022) & 31 & 37 & 27 & 22 & 28 & 19 & 40 & 33 \\
\hline Staurosira construens var. venter (172006) & 32 & 40 & 39 & 38 & 40 & 20 & 28 & 51 \\
\hline Staurosirella lapponica (175002) & & 14 & & & & & & \\
\hline $\begin{array}{l}\text { Staurosirella leptostauron var. rhomboides } \\
\text { (175017) }\end{array}$ & 1 & 1 & & & & 3 & & \\
\hline Staurosirella pinnata (175005) & 18 & 19 & 37 & 24 & 16 & 25 & 25 & 32 \\
\hline \multicolumn{9}{|l|}{ Stenopterobia anceps (63003) } \\
\hline \multicolumn{9}{|l|}{ Stenopterobia delicatissima (63007) } \\
\hline \multicolumn{9}{|l|}{ Surirella amphioxys (65069) } \\
\hline \multicolumn{9}{|l|}{ Surirella angusta (65002) } \\
\hline \multicolumn{9}{|l|}{ Surirella elegans (65072) } \\
\hline \multicolumn{9}{|l|}{ Surirella gracilis (65013) } \\
\hline Surirella linearis (65014) & 1 & & & & & & & \\
\hline Tabellaria fenestrata (67002) & & & & & & 1 & & \\
\hline Tabellaria flocculosa (67004) & 1 & 7 & 4 & 9 & 12 & 6 & 6 & 4 \\
\hline \multicolumn{9}{|l|}{ Tabularia fasciculata (200002) } \\
\hline Tetracyclus glans (71006) & & & & 1 & & & & \\
\hline \multicolumn{9}{|l|}{ Tetracyclus lacustris (71003) } \\
\hline Total chrysophyte cysts per slice & & 47 & & 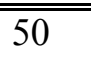 & & 79 & & \\
\hline Total diatom counts per slice & 423 & 476 & 436 & 420 & 473 & 476 & 425 & 508 \\
\hline Total microspheres per slice & & 27 & & 27 & & 24 & & 21 \\
\hline
\end{tabular}




\section{Appendix D. List of stratigraphic and sedimentary values for the Danny's Lake sediment core}

Ratio of cyst to diatom, Shannon diversity index, axis 1 PCA, axis 1 DCA, organic, carbonate and clay percent, magnetic susceptibility and grainsize (um) 
Appendix D. List of stratigraphic and sedimentary values for the Danny's Lake sediment core

\begin{tabular}{|c|c|c|c|c|c|c|c|c|c|}
\hline $\begin{array}{c}\text { Depth } \\
\text { (cm) }\end{array}$ & C:D & Shan & $\begin{array}{c}\text { Axis } 1 \\
\text { PCA }\end{array}$ & $\begin{array}{c}\text { Axis } 1 \\
\text { DCA }\end{array}$ & Org & Carb & Cla & $\begin{array}{c}\text { Mag } \\
\text { Sus }\end{array}$ & $\begin{array}{c}\text { Mean } \\
\text { grain } \\
\text { size }\end{array}$ \\
\hline 0.2 & & & & & & & & & 30.16 \\
\hline 0.3 & & & & & & & & -1.3 & \\
\hline 0.4 & & & & & & & & -2.4 & \\
\hline 0.5 & 5.59 & 2.97 & 0.094 & 64 & & & & & 32.57 \\
\hline 0.6 & & & & & & & & -2.9 & \\
\hline 0.7 & 5.85 & 2.81 & 0.088 & 31 & & & & & \\
\hline 0.8 & & & & & & & & & 31.73 \\
\hline 0.9 & & & & & & & & -0.9 & \\
\hline 1.2 & & & & & & & & -3 & 32.29 \\
\hline 1.3 & & & & & & & & -1.6 & \\
\hline 1.4 & 2.63 & 2.64 & 0.093 & 25 & & & & & \\
\hline 1.5 & & & & & & & & -2 & \\
\hline 1.6 & & & & & & & & & 32.11 \\
\hline 1.7 & 26.38 & 2.28 & 0.092 & 9 & & & & & \\
\hline 1.8 & & & & & & & & -1.4 & \\
\hline 2 & & & & & & & & & 32.34 \\
\hline 2.1 & & & & & & & & -1 & \\
\hline 2.2 & & & & & & & & -2.4 & \\
\hline 2.3 & 5.86 & 2.79 & 0.091 & 82 & & & & & \\
\hline 2.4 & & & & & & & & -1.4 & 34.16 \\
\hline 2.5 & 5.00 & 2.72 & 0.092 & 16 & & & & & \\
\hline 2.7 & & & & & & & & -0.9 & \\
\hline 2.8 & & & & & & & & & 34.88 \\
\hline 3 & & & & & & & & -4.4 & \\
\hline 3.1 & & & & & & & & 0.2 & \\
\hline 3.2 & 17.67 & 2.42 & 0.094 & 26 & & & & & 35.23 \\
\hline 3.3 & & & & & & & & -1.7 & \\
\hline 3.4 & 27.94 & 2.33 & 0.092 & 11 & & & & & \\
\hline 3.6 & & & & & & & & -1.9 & 35.20 \\
\hline 3.9 & & & & & & & & -0.2 & \\
\hline 4 & & & & & & & & -1.8 & 34.44 \\
\hline 4.1 & 9.76 & 3.04 & 0.094 & 61 & & & & & \\
\hline 4.2 & & & & & & & & -0.3 & \\
\hline 4.3 & 9.84 & 2.89 & 0.089 & 25 & & & & & \\
\hline 4.4 & & & & & & & & & 36.76 \\
\hline 4.5 & & & & & & & & -1 & \\
\hline 4.7 & & & & & & & & & 32.86 \\
\hline 4.8 & & & & & & & & -1.9 & \\
\hline
\end{tabular}


Appendix D. List of stratigraphic and sedimentary values for the Danny's Lake sediment core

\begin{tabular}{|c|c|c|c|c|c|c|c|c|c|}
\hline $\begin{array}{l}\text { Depth } \\
\text { (cm) }\end{array}$ & C:D & $\begin{array}{c}\text { Sha } \\
\text { n }\end{array}$ & $\begin{array}{c}\text { Axis 1 } \\
\text { PCA }\end{array}$ & $\begin{array}{c}\text { Axis 1 } \\
\text { DCA }\end{array}$ & $\begin{array}{c}\text { Or } \\
\text { g }\end{array}$ & $\begin{array}{c}\text { Car } \\
\text { b }\end{array}$ & $\begin{array}{c}\mathbf{C l} \\
\mathbf{a}\end{array}$ & $\begin{array}{l}\text { Mag } \\
\text { Sus }\end{array}$ & $\begin{array}{c}\text { Mean grain } \\
\text { size }\end{array}$ \\
\hline 4.9 & & & & & & & & -2.2 & \\
\hline 5 & 8.94 & 2.94 & 0.094 & 35 & & & & & 35.98 \\
\hline 5.1 & & & & & & & & -1.3 & \\
\hline 5.2 & 7.39 & 2.75 & 0.079 & 6 & & & & & \\
\hline 5.4 & & & & & & & & -1.9 & 32.52 \\
\hline 5.7 & & & & & & & & -0.5 & \\
\hline 5.8 & & & & & & & & & 32.63 \\
\hline 5.9 & 1.00 & 2.38 & 0.094 & 31 & & & & & \\
\hline 6 & & & & & & & & -0.4 & \\
\hline 6.1 & 7.56 & 2.76 & 0.094 & 30 & & & & & 29.53 \\
\hline 6.3 & & & & & & & & 0 & 40.45 \\
\hline 6.5 & & & & & & & & & 40.22 \\
\hline 6.6 & & & & & & & & -0.4 & \\
\hline 6.7 & & & & & & & & -0.4 & 36.05 \\
\hline 6.8 & 9.98 & 3.04 & 0.094 & 53 & & & & & \\
\hline 6.9 & & & & & & & & -1.8 & 35.81 \\
\hline 7 & 5.99 & 2.71 & 0.093 & 23 & & & & & \\
\hline 7.1 & & & & & & & & -0.9 & 32.83 \\
\hline 7.2 & & & & & & & & -3 & \\
\hline 7.3 & & & & & & & & & 35.40 \\
\hline 7.5 & & & & & & & & -1 & 33.22 \\
\hline 7.6 & & & & & & & & -2.9 & \\
\hline 7.7 & $\begin{array}{c}14.3 \\
4\end{array}$ & 2.71 & 0.095 & 42 & & & & & 33.98 \\
\hline 7.8 & & & & & & & & -1.9 & \\
\hline 7.9 & & & & & & & & -1.3 & 35.77 \\
\hline 8 & 6.33 & 2.85 & 0.090 & 36 & & & & & \\
\hline 8.1 & & & & & & & & -2 & 35.00 \\
\hline 8.3 & & & & & & & & & 36.36 \\
\hline 8.4 & & & & & & & & -1.9 & \\
\hline 8.5 & & & & & & & & -0.3 & 32.57 \\
\hline 8.6 & 1.70 & 2.77 & 0.092 & 21 & & & & & \\
\hline 8.7 & & & & & & & & -1.4 & 34.81 \\
\hline 8.8 & & & & & & & & -2.4 & \\
\hline 8.9 & 6.89 & 2.97 & 0.094 & 50 & & & & & 33.50 \\
\hline 9 & & & & & & & & -2.9 & \\
\hline 9.1 & & & & & & & & & 35.92 \\
\hline 9.3 & & & & & & & & -0.9 & 34.01 \\
\hline 9.4 & & & & & & & & -1.9 & \\
\hline
\end{tabular}


Appendix D. List of stratigraphic and sedimentary values for the Danny's Lake sediment core

\begin{tabular}{|c|c|c|c|c|c|c|c|c|c|}
\hline $\begin{array}{l}\text { Depth } \\
\text { (cm) }\end{array}$ & C:D & $\begin{array}{c}\text { Sha } \\
\text { n }\end{array}$ & $\begin{array}{c}\text { Axis 1 } \\
\text { PCA }\end{array}$ & $\begin{array}{c}\text { Axis 1 } \\
\text { DCA }\end{array}$ & $\begin{array}{c}\text { Or } \\
\text { g }\end{array}$ & $\begin{array}{c}\text { Car } \\
\text { b }\end{array}$ & Cla & $\begin{array}{c}\text { Mag } \\
\text { Sus }\end{array}$ & $\begin{array}{c}\text { Mean grain } \\
\text { size }\end{array}$ \\
\hline 9.5 & $\begin{array}{c}16.5 \\
3\end{array}$ & 2.76 & 0.078 & 20 & & & & & 33.94 \\
\hline 9.6 & & & & & & & & -2.5 & \\
\hline 9.7 & & & & & & & & -0.8 & 30.90 \\
\hline 9.8 & 1.34 & 2.19 & 0.091 & 0 & & & & & \\
\hline 9.9 & & & & & & & & -1 & 31.11 \\
\hline 10 & & & & & $\begin{array}{c}26 . \\
0\end{array}$ & 5.1 & $\begin{array}{c}68 . \\
9\end{array}$ & & \\
\hline 10.1 & & & & & & & & & 32.51 \\
\hline 10.2 & & & & & & & & -2.9 & \\
\hline 10.3 & & & & & & & & & 33.41 \\
\hline 10.4 & 1.78 & 2.66 & 0.095 & 37 & & & & & \\
\hline 10.5 & & & & & & & & 0.4 & 30.89 \\
\hline 10.6 & & & & & & & & -2.4 & \\
\hline 10.7 & 4.88 & 2.92 & 0.095 & 57 & & & & & 33.29 \\
\hline 10.8 & & & & & & & & -1.9 & \\
\hline 10.9 & & & & & & & & & 32.09 \\
\hline 11 & & & & & $\begin{array}{c}24 . \\
0\end{array}$ & 3.8 & $\begin{array}{c}72 . \\
2\end{array}$ & & \\
\hline 11.1 & & & & & & & & -1.3 & 31.97 \\
\hline 11.2 & & & & & & & & -2.9 & \\
\hline 11.3 & $\begin{array}{c}15.1 \\
7\end{array}$ & 2.91 & 0.094 & 39 & & & & & 31.26 \\
\hline 11.4 & & & & & & & & -1.9 & \\
\hline 11.5 & & & & & & & & -0.6 & 33.69 \\
\hline 11.6 & 7.97 & 2.82 & 0.094 & 25 & & & & -1.9 & \\
\hline 11.7 & & & & & & & & -1.8 & 36.23 \\
\hline 11.9 & & & & & & & & & 34.40 \\
\hline 12 & & & & & $\begin{array}{c}25 . \\
4\end{array}$ & 3.3 & $\begin{array}{c}71 . \\
3\end{array}$ & -2 & \\
\hline 12.1 & & & & & & & & 0.3 & 33.90 \\
\hline 12.2 & $\begin{array}{c}13.8 \\
6\end{array}$ & 2.66 & 0.095 & 34 & & & & & \\
\hline 12.3 & & & & & & & & -2.4 & 34.87 \\
\hline 12.4 & $\begin{array}{c}26.2 \\
7\end{array}$ & 2.73 & 0.094 & 33 & & & & -2.3 & \\
\hline 12.5 & & & & & & & & -1.9 & 31.59 \\
\hline 12.7 & & & & & & & & & 36.44 \\
\hline 12.8 & & & & & & & & -1.5 & \\
\hline 12.9 & & & & & & & & & 34.13 \\
\hline 13 & $\begin{array}{c}10.0 \\
0\end{array}$ & 2.85 & 0.093 & 34 & $\begin{array}{c}23 . \\
9\end{array}$ & 3.8 & $\begin{array}{c}72 . \\
3\end{array}$ & & \\
\hline 13.1 & & & & & & & & -0.5 & 34.82 \\
\hline 13.2 & & & & & & & & -0.7 & \\
\hline
\end{tabular}


Appendix D. List of stratigraphic and sedimentary values for the Danny's Lake sediment core

\begin{tabular}{|c|c|c|c|c|c|c|c|c|c|}
\hline $\begin{array}{l}\text { Depth } \\
\text { (cm) }\end{array}$ & C:D & $\begin{array}{c}\text { Sha } \\
\text { n }\end{array}$ & $\begin{array}{c}\text { Axis 1 } \\
\text { PCA }\end{array}$ & $\begin{array}{c}\text { Axis 1 } \\
\text { DCA }\end{array}$ & $\begin{array}{c}\text { Or } \\
\text { g }\end{array}$ & $\begin{array}{c}\text { Car } \\
\text { b }\end{array}$ & Cla & $\begin{array}{l}\text { Mag } \\
\text { Sus }\end{array}$ & $\begin{array}{c}\text { Mean grain } \\
\text { size }\end{array}$ \\
\hline 13.3 & $\begin{array}{c}16.7 \\
7\end{array}$ & 2.87 & 0.094 & 38 & & & & & 34.45 \\
\hline 13.4 & & & & & & & & -2.3 & \\
\hline 13.5 & & & & & & & & & 35.14 \\
\hline 13.7 & & & & & & & & -3.4 & 34.15 \\
\hline 13.8 & & & & & & & & -0.6 & \\
\hline 13.9 & $\begin{array}{c}12.7 \\
8\end{array}$ & 2.96 & 0.094 & 42 & & & & & 33.04 \\
\hline 14 & & & & & $\begin{array}{c}23 . \\
2\end{array}$ & 3.2 & $\begin{array}{c}73 . \\
6\end{array}$ & -0.8 & \\
\hline 14.1 & & & & & & & & -1.1 & 32.65 \\
\hline 14.2 & 1.69 & 2.73 & 0.095 & 35 & & & & -1 & \\
\hline 14.3 & & & & & & & & -2.9 & 34.28 \\
\hline 14.5 & & & & & & & & & 35.40 \\
\hline 14.6 & & & & & & & & -1.2 & \\
\hline 14.7 & & & & & & & & -1.3 & 36.17 \\
\hline 14.8 & $\begin{array}{c}11.3 \\
6\end{array}$ & 2.76 & 0.094 & 35 & & & & & \\
\hline 14.9 & & & & & & & & -2.4 & 33.97 \\
\hline 15 & & & & & $\begin{array}{c}20 . \\
8\end{array}$ & 3.3 & $\begin{array}{c}75 . \\
9\end{array}$ & -0.1 & \\
\hline 15.1 & 8.29 & 2.65 & 0.094 & 28 & & & & -2.3 & 37.71 \\
\hline 15.3 & & & & & & & & & 34.74 \\
\hline 15.5 & & & & & & & & -0.1 & 34.11 \\
\hline 15.6 & & & & & & & & -2 & \\
\hline 15.7 & $\begin{array}{c}13.5 \\
4\end{array}$ & 2.83 & 0.094 & 43 & & & & & 35.17 \\
\hline 15.8 & & & & & & & & -1.3 & \\
\hline 15.9 & & & & & & & & -1.8 & 34.84 \\
\hline 16 & $\begin{array}{c}13.2 \\
0\end{array}$ & 2.88 & 0.095 & 32 & $\begin{array}{c}22 . \\
5\end{array}$ & 2.1 & $\begin{array}{c}75 . \\
4\end{array}$ & & \\
\hline 16.1 & & & & & & & & 0.5 & 33.15 \\
\hline 16.3 & & & & & & & & & 32.44 \\
\hline 16.4 & & & & & & & & 2.2 & \\
\hline 16.5 & & & & & & & & -1.7 & 35.05 \\
\hline 16.6 & 7.93 & 2.54 & 0.095 & 31 & & & & & \\
\hline 16.7 & & & & & & & & -1.2 & 34.23 \\
\hline 16.8 & & & & & & & & -0.3 & \\
\hline 16.9 & 9.83 & 2.87 & 0.093 & 28 & & & & -0.1 & 34.34 \\
\hline 17 & & & & & $\begin{array}{c}21 . \\
2\end{array}$ & 2.1 & $\begin{array}{c}76 . \\
7\end{array}$ & -0.8 & \\
\hline 17.1 & & & & & & & & & 34.69 \\
\hline 17.3 & & & & & & & & -0.8 & 34.15 \\
\hline
\end{tabular}


Appendix D. List of stratigraphic and sedimentary values for the Danny's Lake sediment core

\begin{tabular}{|c|c|c|c|c|c|c|c|c|c|}
\hline $\begin{array}{c}\text { Depth } \\
(\mathrm{cm})\end{array}$ & C:D & $\begin{array}{c}\text { Sha } \\
\text { n }\end{array}$ & $\begin{array}{c}\text { Axis 1 } \\
\text { PCA } \\
\end{array}$ & $\begin{array}{c}\text { Axis 1 } \\
\text { DCA }\end{array}$ & $\begin{array}{c}\text { Or } \\
\mathrm{g}\end{array}$ & $\begin{array}{c}\text { Car } \\
\text { b }\end{array}$ & Cla & $\begin{array}{l}\text { Mag } \\
\text { Sus } \\
\end{array}$ & $\begin{array}{c}\text { Mean grain } \\
\text { size }\end{array}$ \\
\hline 17.4 & & & & & & & & -1.8 & \\
\hline 17.5 & $\begin{array}{c}15.4 \\
6\end{array}$ & 3.07 & 0.091 & 50 & & & & & 34.40 \\
\hline 17.6 & & & & & & & & -1.6 & \\
\hline 17.7 & & & & & & & & 0.2 & 34.29 \\
\hline 17.8 & 1.86 & 2.67 & 0.095 & 33 & & & & -2 & \\
\hline 17.9 & & & & & & & & -1.4 & 31.88 \\
\hline 18 & & & & & $\begin{array}{c}22 \\
3\end{array}$ & 2.4 & $\begin{array}{c}75 . \\
3\end{array}$ & & \\
\hline 18.1 & & & & & & & & & 31.80 \\
\hline 18.2 & & & & & & & & -1.1 & \\
\hline 18.3 & & & & & & & & 0.5 & 38.41 \\
\hline 18.5 & $\begin{array}{c}14.8 \\
0\end{array}$ & 3.06 & 0.089 & 69 & & & & -0.7 & 33.14 \\
\hline 18.6 & & & & & & & & -1.2 & \\
\hline 18.7 & 4.12 & 2.66 & 0.094 & 28 & & & & & 35.50 \\
\hline 18.8 & & & & & & & & 0 & \\
\hline 18.9 & & & & & & & & & 36.33 \\
\hline 19 & & & & & $\begin{array}{c}23 . \\
0\end{array}$ & 2.8 & $\begin{array}{c}74 . \\
2\end{array}$ & -1.3 & \\
\hline 19.3 & 5.75 & 2.84 & 0.095 & 56 & & & & & 39.11 \\
\hline 19.4 & & & & & & & & -1 & \\
\hline 19.5 & & & & & & & & & 38.34 \\
\hline 19.6 & 8.58 & 2.99 & 0.093 & 57 & & & & -0.3 & \\
\hline 19.7 & & & & & & & & & 35.24 \\
\hline 19.9 & & & & & & & & & 36.95 \\
\hline 20 & & & & & $\begin{array}{c}21 . \\
8\end{array}$ & 1.9 & $\begin{array}{c}76 . \\
3\end{array}$ & -0.2 & \\
\hline 20.1 & & & & & & & & & 37.10 \\
\hline 20.2 & 1.96 & 2.88 & 0.093 & 63 & & & & & \\
\hline 20.3 & & & & & & & & & 35.59 \\
\hline 20.4 & & & & & & & & 0.1 & \\
\hline 20.5 & 7.89 & 2.99 & 0.095 & 57 & & & & & 37.52 \\
\hline 20.7 & & & & & & & & & 33.33 \\
\hline 20.9 & & & & & & & & & 34.99 \\
\hline 21 & & & & & $\begin{array}{c}21 . \\
2\end{array}$ & 2.0 & $\begin{array}{c}76 . \\
8\end{array}$ & 1 & \\
\hline 21.1 & 1.57 & 2.98 & 0.095 & 50 & & & & & \\
\hline 21.2 & & & & & & & & 0.5 & \\
\hline 21.3 & & & & & & & & & 39.50 \\
\hline 21.4 & 9.58 & 2.83 & 0.094 & 52 & & & & & \\
\hline
\end{tabular}


Appendix D. List of stratigraphic and sedimentary values for the Danny's Lake sediment core

\begin{tabular}{|c|c|c|c|c|c|c|c|c|c|}
\hline $\begin{array}{c}\text { Depth } \\
(\mathrm{cm})\end{array}$ & C:D & $\begin{array}{c}\text { Sha } \\
\text { n }\end{array}$ & $\begin{array}{c}\text { Axis 1 } \\
\text { PCA }\end{array}$ & $\begin{array}{c}\text { Axis 1 } \\
\text { DCA }\end{array}$ & $\begin{array}{c}\text { Or } \\
\mathrm{g}\end{array}$ & $\begin{array}{c}\text { Car } \\
\text { b }\end{array}$ & Cla & $\begin{array}{c}\text { Mag } \\
\text { Sus }\end{array}$ & $\begin{array}{c}\begin{array}{c}\text { Mean grain } \\
\text { size }\end{array} \\
\end{array}$ \\
\hline 21.5 & & & & & & & & & 36.25 \\
\hline 21.7 & & & & & & & & & 39.89 \\
\hline 21.9 & & & & & & & & -1 & 37.35 \\
\hline 22 & & & & & $\begin{array}{c}22 . \\
4\end{array}$ & 1.6 & $\begin{array}{c}76 . \\
0\end{array}$ & & \\
\hline 22.1 & $\begin{array}{c}11.5 \\
6\end{array}$ & 3.12 & 0.092 & 63 & & & & & 37.29 \\
\hline 22.3 & & & & & & & & 0.1 & 34.95 \\
\hline 22.4 & 7.79 & 2.79 & 0.094 & 43 & & & & & \\
\hline 22.5 & & & & & & & & 0.8 & 37.21 \\
\hline 22.7 & & & & & & & & & 36.18 \\
\hline 22.9 & & & & & & & & 0.7 & 38.03 \\
\hline 22.97 & 9.98 & 2.69 & 0.095 & 48 & & & & & \\
\hline 23 & & & & & $\begin{array}{c}22 . \\
4\end{array}$ & 2.1 & $\begin{array}{c}75 . \\
5\end{array}$ & & \\
\hline 23.1 & & & & & & & & -0.7 & 37.63 \\
\hline 23.3 & $\begin{array}{c}18.7 \\
8\end{array}$ & 2.70 & 0.093 & 53 & & & & 0.1 & 39.54 \\
\hline 23.5 & & & & & & & & & 36.98 \\
\hline 23.7 & & & & & & & & -0.9 & 36.70 \\
\hline 23.8 & & & & & & & & -1 & \\
\hline 23.9 & 1.98 & 3.02 & 0.093 & 69 & & & & & 36.22 \\
\hline 24 & & & & & $\begin{array}{c}21 . \\
6\end{array}$ & 1.7 & $\begin{array}{c}76 . \\
7\end{array}$ & 0.5 & \\
\hline 24.1 & & & & & & & & 0 & 42.92 \\
\hline 24.2 & 9.84 & 2.74 & 0.094 & 37 & & & & & \\
\hline 24.3 & & & & & & & & 0.1 & 38.61 \\
\hline 24.5 & & & & & & & & & 35.53 \\
\hline 24.6 & & & & & & & & -0.9 & \\
\hline 24.7 & & & & & & & & -0.3 & 39.75 \\
\hline 24.9 & $\begin{array}{c}13.2 \\
2\end{array}$ & 2.81 & 0.095 & 58 & & & & & 37.11 \\
\hline 25 & & & & & $\begin{array}{c}21 . \\
0\end{array}$ & 1.6 & $\begin{array}{c}77 . \\
4\end{array}$ & 0 & \\
\hline 25.1 & & & & & & & & & 32.35 \\
\hline 25.2 & & & & & & & & 3 & \\
\hline 25.3 & & 2.38 & 0.094 & 49 & & & & 0.2 & 35.55 \\
\hline 25.5 & & & & & & & & & 39.07 \\
\hline 25.6 & & & & & & & & -0.8 & \\
\hline 25.7 & $\begin{array}{c}12.1 \\
7\end{array}$ & 2.64 & 0.094 & 41 & & & & -0.5 & 36.39 \\
\hline 25.9 & & & & & & & & & 31.94 \\
\hline 26 & & & & & $\begin{array}{c}26 . \\
0\end{array}$ & 2.4 & $\begin{array}{c}71 . \\
6\end{array}$ & -0.2 & \\
\hline
\end{tabular}


Appendix D. List of stratigraphic and sedimentary values for the Danny's Lake sediment core

\begin{tabular}{|c|c|c|c|c|c|c|c|c|c|}
\hline $\begin{array}{l}\text { Depth } \\
\text { (cm) }\end{array}$ & C:D & $\begin{array}{c}\text { Sha } \\
\text { n }\end{array}$ & $\begin{array}{c}\text { Axis 1 } \\
\text { PCA }\end{array}$ & $\begin{array}{c}\text { Axis 1 } \\
\text { DCA }\end{array}$ & $\begin{array}{c}\text { Or } \\
\text { g }\end{array}$ & $\begin{array}{c}\text { Car } \\
\text { b }\end{array}$ & Cla & $\begin{array}{l}\text { Mag } \\
\text { Sus }\end{array}$ & $\begin{array}{l}\text { Mean grain } \\
\text { size }\end{array}$ \\
\hline 26.1 & & & & & & & & -0.6 & 37.94 \\
\hline 26.3 & & 2.65 & 0.094 & 66 & & & & -1 & 38.29 \\
\hline 26.5 & & & & & & & & & 37.02 \\
\hline 26.6 & & & & & & & & -2.5 & \\
\hline 26.7 & 6.98 & 2.90 & 0.094 & 34 & & & & -0.3 & 33.71 \\
\hline 26.9 & & & & & & & & & 35.93 \\
\hline 27 & & & & & $\begin{array}{c}24 . \\
4\end{array}$ & 3.0 & $\begin{array}{c}72 . \\
7\end{array}$ & 0.3 & \\
\hline 27.1 & & & & & & & & -0.1 & 36.08 \\
\hline 27.2 & & & & & & & & -0.6 & \\
\hline 27.3 & & 2.59 & 0.093 & 69 & & & & -0.1 & 35.60 \\
\hline 27.5 & & & & & & & & & 34.47 \\
\hline 27.6 & & & & & & & & -1.9 & \\
\hline 27.7 & & & & & & & & -1 & 32.68 \\
\hline 27.8 & $\begin{array}{c}12.6 \\
2\end{array}$ & 2.91 & 0.094 & 60 & & & & & \\
\hline 27.9 & & & & & & & & & 36.69 \\
\hline 28 & & & & & $\begin{array}{c}27 . \\
8\end{array}$ & 4.8 & $\begin{array}{c}67 . \\
3\end{array}$ & 0.3 & \\
\hline 28.1 & & & & & & & & -4.1 & 35.31 \\
\hline 28.2 & & 2.53 & 0.095 & 70 & & & & 1.3 & \\
\hline 28.3 & & & & & & & & & 39.23 \\
\hline 28.5 & & & & & & & & -0.5 & 37.39 \\
\hline 28.6 & 6.19 & 2.79 & 0.094 & 46 & & & & -0.3 & \\
\hline 28.7 & & & & & & & & & 35.75 \\
\hline 28.8 & & & & & & & & -0.8 & \\
\hline 28.9 & & 2.45 & 0.094 & 55 & & & & -1.5 & 35.70 \\
\hline 29 & & & & & $\begin{array}{c}24 . \\
2\end{array}$ & 2.2 & $\begin{array}{c}73 . \\
6\end{array}$ & 0.5 & \\
\hline 29.1 & & & & & & & & -0.4 & 35.24 \\
\hline 29.3 & & & & & & & & & 35.04 \\
\hline 29.4 & & & & & & & & -0.4 & \\
\hline 29.5 & $\begin{array}{c}12.9 \\
8\end{array}$ & 2.61 & 0.094 & 22 & & & & -1.8 & 35.08 \\
\hline 29.7 & & & & & & & & 0.6 & 33.18 \\
\hline 29.8 & & & & & & & & -0.5 & \\
\hline 29.9 & & 2.51 & 0.094 & 64 & & & & -1 & 34.32 \\
\hline 30 & & & & & $\begin{array}{c}24 . \\
1\end{array}$ & 2.1 & $\begin{array}{c}73 . \\
7\end{array}$ & 1 & \\
\hline 30.1 & & & & & & & & & 34.90 \\
\hline 30.3 & & & & & & & & -1.6 & 36.76 \\
\hline
\end{tabular}


Appendix D. List of stratigraphic and sedimentary values for the Danny's Lake sediment core

\begin{tabular}{|c|c|c|c|c|c|c|c|c|c|}
\hline $\begin{array}{l}\text { Depth } \\
\text { (cm) }\end{array}$ & C:D & $\begin{array}{c}\text { Sha } \\
\text { n }\end{array}$ & $\begin{array}{l}\text { Axis 1 } \\
\text { PCA }\end{array}$ & $\begin{array}{c}\text { Axis 1 } \\
\text { DCA }\end{array}$ & $\begin{array}{c}\text { Or } \\
\text { g }\end{array}$ & $\begin{array}{c}\text { Car } \\
\text { b }\end{array}$ & Cla & $\begin{array}{l}\text { Mag } \\
\text { Sus }\end{array}$ & $\begin{array}{c}\text { Mean grain } \\
\text { size }\end{array}$ \\
\hline 30.4 & & & & & & & & -1.3 & \\
\hline 30.5 & 1.87 & 2.96 & 0.095 & 72 & & & & & 34.81 \\
\hline 30.6 & & & & & & & & -0.8 & \\
\hline 30.7 & & & & & & & & & 35.71 \\
\hline 30.8 & & & & & & & & 0.1 & \\
\hline 30.9 & & 2.49 & 0.094 & 62 & & & & -0.8 & 33.99 \\
\hline 31 & & & & & $\begin{array}{c}29 . \\
5\end{array}$ & 2.7 & $\begin{array}{c}67 . \\
8\end{array}$ & & \\
\hline 31.1 & & & & & & & & & 39.64 \\
\hline 31.2 & & & & & & & & 0.7 & \\
\hline 31.3 & & & & & & & & & 33.77 \\
\hline 31.5 & 9.11 & 2.93 & 0.092 & 37 & & & & -1.8 & 41.55 \\
\hline 31.6 & & & & & & & & -0.6 & \\
\hline 31.7 & & & & & & & & -2.1 & 30.54 \\
\hline 31.9 & & 2.49 & 0.095 & 50 & & & & 1.3 & 31.97 \\
\hline 32 & & & & & $\begin{array}{c}27 . \\
9\end{array}$ & 2.9 & $\begin{array}{c}69 . \\
1\end{array}$ & & \\
\hline 32.1 & & & & & & & & & 35.14 \\
\hline 32.2 & & & & & & & & 0 & \\
\hline 32.3 & & & & & & & & 0.1 & 32.72 \\
\hline 32.5 & & & & & & & & & 33.71 \\
\hline 32.6 & 5.32 & 2.82 & 0.095 & 43 & & & & 0.6 & \\
\hline 32.7 & & & & & & & & -1.6 & 34.22 \\
\hline 32.9 & & & & & & & & & 33.05 \\
\hline 33 & & & & & $\begin{array}{c}26 . \\
1\end{array}$ & 6.5 & $\begin{array}{c}67 . \\
4\end{array}$ & & \\
\hline 33.1 & & & & & & & & -0.7 & 34.10 \\
\hline 33.2 & & & & & & & & 0.3 & \\
\hline 33.3 & $\begin{array}{c}12.2 \\
4\end{array}$ & 3.14 & 0.086 & 93 & & & & & 35.60 \\
\hline 33.5 & & & & & & & & 0 & 34.42 \\
\hline 33.7 & $\begin{array}{c}14.5 \\
0\end{array}$ & 2.99 & 0.090 & 93 & & & & & 32.41 \\
\hline 33.9 & & & & & & & & -1 & 32.25 \\
\hline 34 & & & & & $\begin{array}{c}21 . \\
8\end{array}$ & 4.6 & $\begin{array}{c}73 . \\
6\end{array}$ & & \\
\hline 34.1 & & & & & & & & & 34.08 \\
\hline 34.3 & & & & & & & & 1 & 36.32 \\
\hline 34.5 & & & & & & & & -0.6 & 32.13 \\
\hline 34.6 & $\begin{array}{c}11.8 \\
4\end{array}$ & 2.99 & 0.088 & 91 & & & & & \\
\hline 34.7 & & & & & & & & -0.8 & 32.65 \\
\hline
\end{tabular}


Appendix D. List of stratigraphic and sedimentary values for the Danny's Lake sediment core

\begin{tabular}{|c|c|c|c|c|c|c|c|c|c|}
\hline $\begin{array}{l}\text { Depth } \\
\text { (cm) }\end{array}$ & C:D & $\begin{array}{c}\text { Sha } \\
\text { n }\end{array}$ & $\begin{array}{c}\text { Axis 1 } \\
\text { PCA }\end{array}$ & $\begin{array}{c}\text { Axis 1 } \\
\text { DCA }\end{array}$ & $\begin{array}{c}\text { Or } \\
\text { g }\end{array}$ & $\begin{array}{c}\text { Car } \\
\text { b }\end{array}$ & Cla & $\begin{array}{l}\text { Mag } \\
\text { Sus }\end{array}$ & $\begin{array}{c}\text { Mean grain } \\
\text { size }\end{array}$ \\
\hline 34.9 & & & & & & & & & 32.07 \\
\hline 35 & & & & & $\begin{array}{c}34 . \\
0\end{array}$ & 4.4 & $\begin{array}{c}61 . \\
6\end{array}$ & & \\
\hline 35.1 & & & & & & & & -0.8 & 32.27 \\
\hline 35.3 & & & & & & & & -1 & 33.34 \\
\hline 35.5 & $\begin{array}{c}13.5 \\
4\end{array}$ & 2.96 & 0.091 & 85 & & & & & 33.40 \\
\hline 35.7 & & & & & & & & & 31.90 \\
\hline 35.9 & & & & & & & & & 33.21 \\
\hline 36 & & & & & $\begin{array}{c}26 . \\
7\end{array}$ & 2.6 & $\begin{array}{c}70 . \\
7\end{array}$ & & \\
\hline 36.1 & & & & & & & & -0.8 & \\
\hline 36.3 & 1.45 & 2.97 & 0.088 & 74 & & & & -0.3 & 33.46 \\
\hline 36.4 & & & & & & & & -0.5 & \\
\hline 36.5 & & & & & & & & & 29.70 \\
\hline 36.7 & & & & & & & & & 31.49 \\
\hline 36.8 & & 2.08 & 0.093 & 36 & & & & -1 & \\
\hline 36.9 & & & & & & & & & 36.51 \\
\hline 37 & & & & & $\begin{array}{c}26 . \\
7\end{array}$ & 5.9 & $\begin{array}{c}67 . \\
4\end{array}$ & -0.9 & \\
\hline 37.1 & & & & & & & & & 32.62 \\
\hline 37.2 & $\begin{array}{c}16.4 \\
3\end{array}$ & 3.05 & 0.095 & 69 & & & & & \\
\hline 37.3 & & & & & & & & -1.8 & 34.21 \\
\hline 37.5 & & & & & & & & & 30.58 \\
\hline 37.7 & & 2.65 & 0.094 & 73 & & & & -1.3 & 30.97 \\
\hline 37.9 & & & & & & & & -1.8 & 29.82 \\
\hline 38 & $\begin{array}{c}13.6 \\
6\end{array}$ & 3.09 & 0.090 & 84 & $\begin{array}{c}30 . \\
9\end{array}$ & 4.5 & $\begin{array}{c}64 . \\
7\end{array}$ & & \\
\hline 38.1 & & & & & & & & -1.2 & 32.32 \\
\hline 38.3 & & & & & & & & & 34.45 \\
\hline 38.4 & & 2.43 & 0.094 & 51 & & & & -1.8 & \\
\hline 38.5 & & & & & & & & & 31.86 \\
\hline 38.7 & & & & & & & & & 28.90 \\
\hline 38.8 & $\begin{array}{c}13.4 \\
8\end{array}$ & 3.12 & 0.094 & 80 & & & & & \\
\hline 38.9 & & & & & & & & & 30.98 \\
\hline 39 & & & & & $\begin{array}{c}26 . \\
5\end{array}$ & 3.5 & $\begin{array}{c}70 . \\
1\end{array}$ & -1.5 & \\
\hline 39.1 & & & & & & & & & 29.98 \\
\hline 39.3 & & & & & & & & & 35.18 \\
\hline 39.4 & & & & & & & & -0.1 & \\
\hline 39.5 & & 2.62 & 0.094 & 64 & & & & & 29.30 \\
\hline
\end{tabular}


Appendix D. List of stratigraphic and sedimentary values for the Danny's Lake sediment core

\begin{tabular}{|c|c|c|c|c|c|c|c|c|c|}
\hline $\begin{array}{c}\text { Depth } \\
\text { (cm) }\end{array}$ & C:D & $\begin{array}{c}\text { Sha } \\
\text { n }\end{array}$ & $\begin{array}{c}\text { Axis 1 } \\
\text { PCA }\end{array}$ & $\begin{array}{c}\text { Axis 1 } \\
\text { DCA }\end{array}$ & $\begin{array}{c}\text { Or } \\
\text { g }\end{array}$ & $\begin{array}{c}\text { Car } \\
\text { b }\end{array}$ & Cla & $\begin{array}{l}\text { Mag } \\
\text { Sus } \\
\end{array}$ & $\begin{array}{c}\begin{array}{c}\text { Mean grain } \\
\text { size }\end{array} \\
\end{array}$ \\
\hline 39.7 & & & & & & & & & 32.87 \\
\hline 39.7 & $\begin{array}{c}11.6 \\
2\end{array}$ & 2.89 & 0.095 & 68 & & & & & \\
\hline 39.8 & & & & & & & & -1.5 & \\
\hline 39.9 & & 2.46 & 0.095 & 64 & & & & & 35.29 \\
\hline 40 & & & & & $\begin{array}{c}27 . \\
9\end{array}$ & 2.6 & $\begin{array}{c}69 . \\
5\end{array}$ & & \\
\hline 40.1 & & & & & & & & & 32.52 \\
\hline 40.3 & & & & & & & & & 35.21 \\
\hline 40.4 & & & & & & & & -0.5 & \\
\hline 40.5 & & & & & & & & & 33.89 \\
\hline 40.7 & 1.26 & 3.10 & 0.092 & 93 & & & & & 28.03 \\
\hline 40.9 & & & & & & & & -1 & 32.25 \\
\hline 41 & & & & & $\begin{array}{c}28 . \\
5\end{array}$ & 2.3 & $\begin{array}{c}69 . \\
2\end{array}$ & & \\
\hline 41.1 & & & & & & & & & 28.48 \\
\hline 41.3 & & & & & & & & & 31.51 \\
\hline 41.4 & & 2.71 & 0.093 & 60 & & & & & \\
\hline 41.5 & & & & & & & & -1.3 & 32.75 \\
\hline 41.6 & $\begin{array}{c}12.7 \\
2\end{array}$ & 3.20 & 0.083 & 94 & & & & & \\
\hline 41.7 & & & & & & & & -0.9 & 31.65 \\
\hline 41.8 & & 2.67 & 0.093 & 74 & & & & & \\
\hline 41.9 & & & & & & & & & 30.48 \\
\hline 42 & & & & & $\begin{array}{c}29 . \\
5\end{array}$ & 2.9 & $\begin{array}{c}67 . \\
6\end{array}$ & & \\
\hline 42.1 & & & & & & & & & 32.27 \\
\hline 42.2 & & & & & & & & -1.3 & \\
\hline 42.3 & & & & & & & & & 36.14 \\
\hline 42.5 & & & & & & & & & 34.40 \\
\hline 42.6 & $\begin{array}{c}12.3 \\
9\end{array}$ & 3.08 & 0.086 & 100 & & & & & \\
\hline 42.7 & & & & & & & & & 34.13 \\
\hline 42.8 & & & & & & & & -0.5 & \\
\hline 42.9 & & & & & & & & & 33.34 \\
\hline 43 & & & & & $\begin{array}{c}33 . \\
3\end{array}$ & 7.7 & $\begin{array}{c}58 . \\
9\end{array}$ & & \\
\hline 43.1 & & & & & & & & & 31.42 \\
\hline 43.2 & & & & & & & & -0.8 & \\
\hline 43.3 & & 2.65 & 0.095 & 74 & & & & & 31.46 \\
\hline 43.5 & $\begin{array}{c}14.6 \\
4\end{array}$ & 3.19 & 0.081 & 103 & & & & & 31.78 \\
\hline 43.6 & & & & & & & & -1 & \\
\hline
\end{tabular}


Appendix D. List of stratigraphic and sedimentary values for the Danny's Lake sediment core

\begin{tabular}{|c|c|c|c|c|c|c|c|c|c|}
\hline $\begin{array}{l}\text { Depth } \\
\text { (cm) }\end{array}$ & C:D & $\begin{array}{c}\text { Sha } \\
\text { n }\end{array}$ & $\begin{array}{c}\text { Axis 1 } \\
\text { PCA }\end{array}$ & $\begin{array}{c}\text { Axis 1 } \\
\text { DCA }\end{array}$ & $\begin{array}{c}\text { Or } \\
\text { g }\end{array}$ & $\begin{array}{c}\text { Car } \\
\text { b }\end{array}$ & Cla & $\begin{array}{l}\text { Mag } \\
\text { Sus }\end{array}$ & $\begin{array}{c}\text { Mean grain } \\
\text { size }\end{array}$ \\
\hline 43.7 & & & & & & & & & 28.90 \\
\hline 43.9 & & & & & & & & -1 & 34.25 \\
\hline 44 & & & & & $\begin{array}{c}29 . \\
9\end{array}$ & 6.6 & $\begin{array}{c}63 . \\
6\end{array}$ & & \\
\hline 44.1 & & & & & & & & -0.2 & 32.75 \\
\hline 44.2 & & 2.58 & 0.094 & 68 & & & & & \\
\hline 44.3 & $\begin{array}{c}15.2 \\
4\end{array}$ & 3.26 & 0.086 & 112 & & & & & 34.06 \\
\hline 44.5 & & & & & & & & -1 & 32.61 \\
\hline 44.7 & & & & & & & & & 32.73 \\
\hline 44.9 & & & & & & & & & 28.27 \\
\hline 45 & & & & & $\begin{array}{c}26 . \\
5\end{array}$ & 4.0 & $\begin{array}{c}69 . \\
4\end{array}$ & & \\
\hline 45.1 & & & & & & & & -0.2 & 33.59 \\
\hline 45.2 & 9.65 & 3.34 & 0.082 & 111 & & & & & \\
\hline 45.3 & & & & & & & & & 30.70 \\
\hline 45.5 & & & & & & & & & 32.33 \\
\hline 45.7 & & 2.30 & 0.093 & 61 & & & & & 32.12 \\
\hline 45.9 & & & & & & & & -0.4 & 32.23 \\
\hline 46 & & 2.57 & 0.092 & 72 & $\begin{array}{c}29 . \\
1\end{array}$ & 6.0 & $\begin{array}{c}64 . \\
8\end{array}$ & & \\
\hline 46.1 & $\begin{array}{c}16.3 \\
9\end{array}$ & 3.19 & 0.084 & 106 & & & & & 34.30 \\
\hline 46.3 & & & & & & & & & 33.13 \\
\hline 46.5 & & & & & & & & & 33.62 \\
\hline 46.7 & & & & & & & & -0.8 & 34.40 \\
\hline 46.9 & & & & & & & & -0.5 & 32.01 \\
\hline 47 & $\begin{array}{c}14.4 \\
8\end{array}$ & 3.18 & 0.065 & 116 & $\begin{array}{c}33 . \\
9\end{array}$ & 5.1 & $\begin{array}{c}61 . \\
0\end{array}$ & & \\
\hline 47.1 & & 2.43 & 0.094 & 60 & & & & -1.3 & 31.56 \\
\hline 47.3 & & & & & & & & & 32.21 \\
\hline 47.5 & & & & & & & & -1 & 31.81 \\
\hline 47.7 & & & & & & & & -0.8 & 30.08 \\
\hline 47.9 & 1.13 & 3.18 & 0.083 & 103 & & & & & 29.48 \\
\hline 48 & & & & & $\begin{array}{c}28 . \\
5\end{array}$ & 3.9 & $\begin{array}{c}67 . \\
6\end{array}$ & & \\
\hline 48.1 & & & & & & & & -1.7 & 32.26 \\
\hline 48.3 & & & & & & & & & 35.50 \\
\hline 48.4 & & 2.55 & 0.093 & 80 & & & & & \\
\hline 48.5 & & & & & & & & -1 & 29.26 \\
\hline 48.7 & & & & & & & & & 35.58 \\
\hline 48.8 & 4.85 & 3.20 & 0.082 & 109 & & & & & \\
\hline
\end{tabular}


Appendix D. List of stratigraphic and sedimentary values for the Danny's Lake sediment core

\begin{tabular}{|c|c|c|c|c|c|c|c|c|c|}
\hline $\begin{array}{c}\text { Depth } \\
\text { (cm) }\end{array}$ & C:D & $\begin{array}{c}\text { Sha } \\
\text { n }\end{array}$ & $\begin{array}{c}\text { Axis 1 } \\
\text { PCA }\end{array}$ & $\begin{array}{c}\text { Axis 1 } \\
\text { DCA }\end{array}$ & $\begin{array}{c}\text { Or } \\
\text { g }\end{array}$ & $\begin{array}{c}\text { Car } \\
\text { b }\end{array}$ & Cla & $\begin{array}{l}\text { Mag } \\
\text { Sus }\end{array}$ & $\begin{array}{c}\text { Mean grain } \\
\text { size }\end{array}$ \\
\hline 48.9 & & & & & & & & -1 & 30.50 \\
\hline 49.1 & & & & & & & & & 30.04 \\
\hline 49.3 & & & & & & & & & 31.14 \\
\hline 49.5 & & 2.56 & 0.094 & 65 & & & & -1.3 & 32.86 \\
\hline 49.7 & $\begin{array}{c}13.4 \\
2\end{array}$ & 3.33 & 0.070 & 125 & & & & & 30.46 \\
\hline 49.9 & & 2.99 & 0.090 & 98 & & & & -1 & 32.24 \\
\hline 50 & & & & & $\begin{array}{c}28 . \\
9\end{array}$ & 3.4 & $\begin{array}{c}67 . \\
6\end{array}$ & & \\
\hline 50.1 & & & & & & & & & 31.51 \\
\hline 50.3 & & & & & & & & & 31.29 \\
\hline 50.5 & & & & & & & & -1.8 & 32.05 \\
\hline 50.6 & $\begin{array}{c}15.3 \\
8\end{array}$ & 3.23 & 0.085 & 103 & & & & & \\
\hline 50.7 & & & & & & & & -0.1 & 31.99 \\
\hline 50.9 & & & & & & & & & 32.26 \\
\hline 51 & & & & & $\begin{array}{c}27 . \\
9\end{array}$ & 2.7 & $\begin{array}{c}69 . \\
4\end{array}$ & & \\
\hline 51.1 & & & & & & & & -0.9 & 32.94 \\
\hline 51.3 & & & & & & & & & 33.23 \\
\hline 51.4 & & 2.69 & 0.093 & 76 & & & & & \\
\hline 51.5 & & & & & & & & & 33.87 \\
\hline 51.7 & $\begin{array}{c}11.6 \\
3\end{array}$ & 3.24 & 0.089 & 98 & & & & & 34.50 \\
\hline 51.9 & & & & & & & & -0.3 & 32.06 \\
\hline 52 & & & & & $\begin{array}{c}27 . \\
5\end{array}$ & 2.7 & $\begin{array}{c}69 . \\
8\end{array}$ & & \\
\hline 52.1 & & & & & & & & & 32.53 \\
\hline 52.3 & & & & & & & & & 33.95 \\
\hline 52.5 & & & & & & & & -0.2 & 36.98 \\
\hline 52.6 & & 2.76 & 0.094 & 77 & & & & & \\
\hline 52.7 & & & & & & & & & 33.50 \\
\hline 52.9 & 9.89 & 3.27 & 0.064 & 133 & & & & & 33.69 \\
\hline 53 & & & & & $\begin{array}{c}28 . \\
7\end{array}$ & 2.8 & $\begin{array}{c}68 . \\
6\end{array}$ & 0 & \\
\hline 53.1 & & & & & & & & & 34.85 \\
\hline 53.3 & & & & & & & & & 33.44 \\
\hline 53.5 & & & & & & & & & 33.01 \\
\hline 53.6 & & 2.86 & 0.086 & 106 & & & & 0.2 & \\
\hline 53.7 & & & & & & & & & 32.22 \\
\hline 53.8 & & & & & & & & -1 & \\
\hline 53.9 & & & & & & & & & 33.70 \\
\hline
\end{tabular}


Appendix D. List of stratigraphic and sedimentary values for the Danny's Lake sediment core

\begin{tabular}{|c|c|c|c|c|c|c|c|c|c|}
\hline $\begin{array}{l}\text { Depth } \\
\text { (cm) }\end{array}$ & C:D & $\begin{array}{c}\text { Sha } \\
\text { n }\end{array}$ & $\begin{array}{c}\text { Axis 1 } \\
\text { PCA }\end{array}$ & $\begin{array}{c}\text { Axis 1 } \\
\text { DCA }\end{array}$ & $\begin{array}{c}\text { Or } \\
\text { g }\end{array}$ & $\begin{array}{c}\text { Car } \\
\text { b }\end{array}$ & Cla & $\begin{array}{l}\text { Mag } \\
\text { Sus }\end{array}$ & $\begin{array}{c}\text { Mean grain } \\
\text { size }\end{array}$ \\
\hline 54 & & & & & $\begin{array}{c}26 . \\
0\end{array}$ & 1.3 & $\begin{array}{c}72 . \\
7\end{array}$ & & \\
\hline 54.1 & $\begin{array}{c}11.9 \\
5\end{array}$ & 2.95 & 0.079 & 112 & & & & & 33.55 \\
\hline 54.3 & & & & & & & & & 32.42 \\
\hline 54.4 & & & & & & & & 0.3 & \\
\hline 54.5 & & & & & & & & & 31.87 \\
\hline 54.7 & & 2.64 & 0.093 & 81 & & & & -0.8 & 32.16 \\
\hline 54.9 & & & & & & & & & 33.26 \\
\hline 55 & & & & & $\begin{array}{c}22 . \\
9\end{array}$ & 2.2 & $\begin{array}{c}74 . \\
9\end{array}$ & & \\
\hline 55.1 & & & & & & & & & 31.89 \\
\hline 55.2 & & & & & & & & 0.3 & \\
\hline 55.3 & $\begin{array}{c}16.7 \\
2\end{array}$ & 3.21 & 0.073 & 98 & & & & & 32.44 \\
\hline 55.5 & & & & & & & & & 32.21 \\
\hline 55.7 & & & & & & & & & 31.21 \\
\hline 55.8 & & 2.62 & 0.093 & 81 & & & & 0.5 & \\
\hline 55.9 & & & & & & & & & 30.93 \\
\hline 56 & & & & & $\begin{array}{c}22 . \\
6\end{array}$ & 2.6 & $\begin{array}{c}74 . \\
8\end{array}$ & & \\
\hline 56.1 & & & & & & & & & 31.26 \\
\hline 56.3 & & 3.05 & 0.075 & 113 & & & & & 29.64 \\
\hline 56.5 & & & & & & & & & 30.44 \\
\hline
\end{tabular}




\section{Appendix E. Diatom and TSI data for time-series analysis}

Aulacoseira complex and Pseudostaurosira complex relative abundances, along with TSI data (Steinhilber et al., 2009) which were subjected to spectral and wavelet analysis 


\begin{tabular}{|c|c|c|c|}
\hline Cal. yr BP & TSI & Aulacoseira & Pseudostaurosira \\
\hline-58 & 0.14 & -2.3016 & 2.3582 \\
\hline-53 & 0.23 & -1.9034 & 1.9950 \\
\hline-48 & 0.35 & -1.5052 & 1.6319 \\
\hline-43 & 0.44 & -1.1070 & 1.2687 \\
\hline-38 & 0.44 & -0.7088 & 0.9056 \\
\hline-33 & 0.34 & -0.3106 & 0.5424 \\
\hline-28 & 0.22 & 0.0876 & 0.1792 \\
\hline-23 & 0.19 & 0.4859 & -0.1839 \\
\hline-18 & 0.26 & 0.6898 & -0.3949 \\
\hline-13 & 0.36 & 0.7644 & -0.5043 \\
\hline-8 & 0.38 & 0.8389 & -0.6137 \\
\hline-3 & 0.32 & 0.9134 & -0.7232 \\
\hline 3 & 0.22 & 1.0028 & -0.8545 \\
\hline 8 & 0.16 & 1.0773 & -0.9639 \\
\hline 13 & 0.16 & 1.1518 & -1.0733 \\
\hline 18 & 0.16 & 1.2263 & -1.1828 \\
\hline 23 & 0.13 & 1.3009 & -1.2922 \\
\hline 28 & 0.07 & 1.3972 & -1.3725 \\
\hline 33 & 0.01 & 1.5809 & -1.3360 \\
\hline 38 & -0.01 & 1.7646 & -1.2996 \\
\hline 43 & -0.02 & 1.9483 & -1.2631 \\
\hline 48 & -0.04 & 2.1320 & -1.2267 \\
\hline 53 & -0.05 & 1.8523 & -0.8990 \\
\hline 58 & -0.04 & 1.5725 & -0.5714 \\
\hline 63 & 0 & 1.2928 & -0.2437 \\
\hline 68 & 0.06 & 1.0130 & 0.0839 \\
\hline 73 & 0.12 & 0.7333 & 0.4116 \\
\hline 78 & 0.17 & 0.4536 & 0.7393 \\
\hline 83 & 0.19 & 0.1738 & 1.0669 \\
\hline 88 & 0.17 & -0.1059 & 1.3946 \\
\hline 93 & 0.11 & 0.1760 & 0.6274 \\
\hline 98 & 0.02 & 0.5983 & -0.4136 \\
\hline 103 & -0.03 & 0.9551 & -1.2467 \\
\hline 108 & -0.05 & 1.0499 & -1.2485 \\
\hline 113 & -0.04 & 1.1447 & -1.2502 \\
\hline 118 & -0.08 & 1.2395 & -1.2520 \\
\hline 123 & -0.17 & 1.3343 & -1.2537 \\
\hline 128 & -0.27 & 1.4291 & -1.2555 \\
\hline 133 & -0.31 & 1.5240 & -1.2572 \\
\hline 138 & -0.24 & 1.6188 & -1.2590 \\
\hline 143 & -0.11 & 1.7136 & -1.2607 \\
\hline 148 & 0.02 & 1.8084 & -1.2625 \\
\hline
\end{tabular}




\begin{tabular}{|c|c|c|c|}
\hline Cal. yr BP & TSI & Aulacoseira & Pseudostaurosira \\
\hline 153 & 0.12 & 1.9227 & -1.3960 \\
\hline 158 & 0.21 & 2.0500 & -1.6173 \\
\hline 163 & 0.28 & 2.1773 & -1.8386 \\
\hline 168 & 0.31 & 2.0211 & -1.7383 \\
\hline 173 & 0.29 & 1.7939 & -1.5576 \\
\hline 178 & 0.22 & 1.5667 & -1.3769 \\
\hline 183 & 0.16 & 1.3395 & -1.1963 \\
\hline 188 & 0.15 & 1.1124 & -1.0156 \\
\hline 193 & 0.19 & 0.8852 & -0.8349 \\
\hline 198 & 0.24 & 0.6580 & -0.6542 \\
\hline 203 & 0.27 & 0.4309 & -0.4735 \\
\hline 208 & 0.25 & 0.2037 & -0.2928 \\
\hline 213 & 0.19 & 0.1433 & -0.2441 \\
\hline 218 & 0.13 & 0.3330 & -0.3933 \\
\hline 223 & 0.06 & 0.5227 & -0.5424 \\
\hline 228 & -0.02 & 0.5676 & -0.6153 \\
\hline 233 & -0.12 & 0.5158 & -0.6374 \\
\hline 238 & -0.24 & 0.4641 & -0.6595 \\
\hline 243 & -0.36 & 0.4124 & -0.6816 \\
\hline 248 & -0.43 & 0.3607 & -0.7037 \\
\hline 253 & -0.42 & 0.3090 & -0.7257 \\
\hline 258 & -0.36 & 0.2573 & -0.7478 \\
\hline 263 & -0.32 & 0.2056 & -0.7699 \\
\hline 268 & -0.31 & 0.1539 & -0.7920 \\
\hline 273 & -0.33 & 0.1022 & -0.8140 \\
\hline 278 & -0.34 & 0.3395 & -1.1552 \\
\hline 283 & -0.31 & 0.5871 & -1.3342 \\
\hline 288 & -0.27 & 0.8501 & -1.2701 \\
\hline 293 & -0.24 & 1.1131 & -1.2059 \\
\hline 298 & -0.22 & 1.3761 & -1.1418 \\
\hline 303 & -0.18 & 1.6391 & -1.0776 \\
\hline 308 & -0.11 & 1.9020 & -1.0135 \\
\hline 313 & -0.04 & 1.7195 & -0.9296 \\
\hline 318 & 0 & 0.8685 & -0.8162 \\
\hline 323 & 0.02 & 0.5653 & -0.7409 \\
\hline 328 & 0.03 & 0.3990 & -0.6751 \\
\hline 333 & 0.07 & 0.2327 & -0.6093 \\
\hline 338 & 0.12 & 0.0664 & -0.5435 \\
\hline 343 & 0.13 & -0.0998 & -0.4777 \\
\hline 348 & 0.08 & -0.2661 & -0.4118 \\
\hline 353 & 0.01 & 0.2177 & -0.5994 \\
\hline 358 & -0.03 & 0.7260 & -0.7955 \\
\hline
\end{tabular}




\begin{tabular}{|c|c|c|c|}
\hline Cal. yr BP & TSI & Aulacoseira & Pseudostaurosira \\
\hline 363 & 0.02 & 0.6827 & -0.7730 \\
\hline 368 & 0.12 & 0.6394 & -0.7505 \\
\hline 373 & 0.2 & 0.5960 & -0.7279 \\
\hline 378 & 0.21 & 0.5527 & -0.7054 \\
\hline 383 & 0.13 & 0.5093 & -0.6829 \\
\hline 388 & -0.01 & 0.5055 & -0.6825 \\
\hline 393 & -0.15 & 0.6598 & -0.7709 \\
\hline 398 & -0.26 & 0.8141 & -0.8592 \\
\hline 403 & -0.34 & 0.9399 & -0.9526 \\
\hline 408 & -0.41 & 1.0467 & -1.0494 \\
\hline 413 & -0.47 & 1.1535 & -1.1462 \\
\hline 418 & -0.5 & 1.2604 & -1.2429 \\
\hline 423 & -0.49 & 1.3672 & -1.3397 \\
\hline 428 & -0.43 & 0.9591 & -1.1352 \\
\hline 433 & -0.37 & 0.2078 & -0.7299 \\
\hline 438 & -0.34 & -0.5435 & -0.3245 \\
\hline 443 & -0.33 & -0.2029 & -0.4395 \\
\hline 448 & -0.32 & 0.1378 & -0.5544 \\
\hline 453 & -0.29 & 0.4785 & -0.6693 \\
\hline 458 & -0.25 & 0.8192 & -0.7842 \\
\hline 463 & -0.25 & 1.1598 & -0.8991 \\
\hline 468 & -0.32 & 1.9590 & -1.3439 \\
\hline 473 & -0.48 & 2.7582 & -1.7887 \\
\hline 478 & -0.67 & 2.8730 & -1.8781 \\
\hline 483 & -0.86 & 2.5315 & -1.7307 \\
\hline 488 & -0.95 & 2.1900 & -1.5833 \\
\hline 493 & -0.89 & 1.8485 & -1.4358 \\
\hline 498 & -0.79 & 1.5070 & -1.2884 \\
\hline 503 & -0.63 & 1.1655 & -1.1410 \\
\hline 508 & -0.43 & 0.8186 & -0.9597 \\
\hline 513 & -0.23 & 0.4498 & -0.6429 \\
\hline 518 & -0.09 & 0.0811 & -0.3261 \\
\hline 523 & -0.05 & -0.2876 & -0.0094 \\
\hline 528 & -0.11 & -0.3523 & 0.0161 \\
\hline 533 & -0.19 & -0.2143 & -0.1526 \\
\hline 538 & -0.24 & -0.0764 & -0.3214 \\
\hline 543 & -0.21 & 0.0616 & -0.4901 \\
\hline 548 & -0.14 & 0.1996 & -0.6588 \\
\hline 553 & -0.05 & 0.3376 & -0.8276 \\
\hline 558 & 0.07 & 0.4755 & -0.9963 \\
\hline 563 & 0.2 & 0.6136 & -1.1717 \\
\hline 568 & 0.34 & 0.7518 & -1.3487 \\
\hline
\end{tabular}




\begin{tabular}{|c|c|c|c|}
\hline Cal. yr BP & TSI & Aulacoseira & Pseudostaurosira \\
\hline 573 & 0.44 & 0.8899 & -1.5257 \\
\hline 578 & 0.48 & 0.9682 & -1.5906 \\
\hline 583 & 0.48 & 0.9567 & -1.4876 \\
\hline 588 & 0.46 & 0.9451 & -1.3845 \\
\hline 593 & 0.42 & 0.9336 & -1.2815 \\
\hline 598 & 0.36 & 0.9221 & -1.1784 \\
\hline 603 & 0.26 & 0.9105 & -1.0754 \\
\hline 608 & 0.12 & 0.8990 & -0.9723 \\
\hline 613 & -0.04 & 0.9157 & -0.9322 \\
\hline 618 & -0.17 & 0.9748 & -0.9866 \\
\hline 623 & -0.26 & 1.0078 & -1.0232 \\
\hline 628 & -0.31 & 0.9368 & -0.9890 \\
\hline 633 & -0.36 & 0.8658 & -0.9548 \\
\hline 638 & -0.4 & 0.7948 & -0.9206 \\
\hline 643 & -0.42 & 0.7238 & -0.8864 \\
\hline 648 & -0.42 & 0.6528 & -0.8522 \\
\hline 653 & -0.42 & 0.5818 & -0.8179 \\
\hline 658 & -0.44 & 0.5144 & -0.7599 \\
\hline 663 & -0.48 & 0.4613 & -0.6065 \\
\hline 668 & -0.53 & 0.4081 & -0.4530 \\
\hline 673 & -0.53 & 0.3550 & -0.2996 \\
\hline 678 & -0.42 & 0.3405 & -0.3635 \\
\hline 683 & -0.2 & 0.3356 & -0.4818 \\
\hline 688 & 0.07 & 0.3307 & -0.6000 \\
\hline 693 & 0.33 & 0.3258 & -0.7183 \\
\hline 698 & 0.5 & 0.3209 & -0.8366 \\
\hline 703 & 0.56 & 0.3160 & -0.9548 \\
\hline 708 & 0.49 & 0.3111 & -1.0731 \\
\hline 713 & 0.34 & 0.4371 & -1.1631 \\
\hline 718 & 0.19 & 0.5958 & -1.2460 \\
\hline 723 & 0.11 & 0.7545 & -1.3290 \\
\hline 728 & 0.11 & 0.8607 & -1.3959 \\
\hline 733 & 0.16 & 0.8882 & -1.4388 \\
\hline 738 & 0.21 & 0.9157 & -1.4816 \\
\hline 743 & 0.24 & 0.9432 & -1.5245 \\
\hline 748 & 0.26 & 0.9707 & -1.5673 \\
\hline 753 & 0.26 & 0.9982 & -1.6102 \\
\hline 758 & 0.22 & 1.0258 & -1.6530 \\
\hline 763 & 0.15 & 1.0486 & -1.5968 \\
\hline 768 & 0.09 & 1.0645 & -1.3920 \\
\hline 773 & 0.09 & 1.0803 & -1.1873 \\
\hline 778 & 0.13 & 1.0632 & -1.0898 \\
\hline
\end{tabular}




\begin{tabular}{|c|c|c|c|}
\hline Cal. yr BP & TSI & Aulacoseira & Pseudostaurosira \\
\hline 783 & 0.17 & 0.9967 & -1.1534 \\
\hline 788 & 0.18 & 0.9302 & -1.2170 \\
\hline 793 & 0.17 & 0.8637 & -1.2805 \\
\hline 798 & 0.18 & 0.7972 & -1.3441 \\
\hline 803 & 0.24 & 0.7264 & -1.2056 \\
\hline 808 & 0.32 & 0.6556 & -1.0670 \\
\hline 813 & 0.35 & 0.7760 & -1.0099 \\
\hline 818 & 0.3 & 0.9441 & -0.9731 \\
\hline 823 & 0.19 & 1.1122 & -0.9363 \\
\hline 828 & 0.09 & 1.2804 & -0.8995 \\
\hline 833 & 0.07 & 1.4485 & -0.8628 \\
\hline 838 & 0.13 & 0.8306 & -0.8448 \\
\hline 843 & 0.21 & 0.2800 & -0.7989 \\
\hline 848 & 0.27 & 0.1252 & -0.7040 \\
\hline 853 & 0.29 & -0.0296 & -0.6092 \\
\hline 858 & 0.27 & -0.1844 & -0.5144 \\
\hline 863 & 0.24 & -0.3392 & -0.4196 \\
\hline 868 & 0.19 & 0.2567 & -0.8260 \\
\hline 873 & 0.14 & 0.8525 & -1.2324 \\
\hline 878 & 0.11 & 0.6630 & -1.0778 \\
\hline 883 & 0.09 & 0.2772 & -0.7828 \\
\hline 888 & 0.1 & -0.1087 & -0.4879 \\
\hline 893 & 0.1 & -0.4945 & -0.1929 \\
\hline 898 & 0.07 & -0.2762 & -0.1393 \\
\hline 903 & 0.02 & 0.3449 & -0.2466 \\
\hline 908 & -0.08 & 0.8169 & -0.3258 \\
\hline 913 & -0.19 & 0.6925 & -0.2924 \\
\hline 918 & -0.3 & 0.5680 & -0.2590 \\
\hline 923 & -0.35 & 0.4436 & -0.2257 \\
\hline 928 & -0.29 & 0.3191 & -0.1923 \\
\hline 933 & -0.17 & -0.2904 & -0.3203 \\
\hline 938 & -0.04 & -0.8999 & -0.4483 \\
\hline 943 & 0.02 & -0.8326 & -0.4179 \\
\hline 948 & 0.01 & -0.5963 & -0.3478 \\
\hline 953 & -0.05 & -0.3599 & -0.2778 \\
\hline 958 & -0.12 & -0.1235 & -0.2077 \\
\hline 963 & -0.14 & -0.0013 & -0.1344 \\
\hline 968 & -0.08 & -0.3361 & -0.0475 \\
\hline 973 & 0.05 & -0.6710 & 0.0393 \\
\hline 978 & 0.19 & -0.6093 & -0.0932 \\
\hline 983 & 0.31 & -0.4486 & -0.2805 \\
\hline 988 & 0.38 & -0.2878 & -0.4678 \\
\hline
\end{tabular}




\begin{tabular}{|c|c|c|c|}
\hline Cal. yr BP & TSI & Aulacoseira & Pseudostaurosira \\
\hline 993 & 0.39 & -0.1271 & -0.6550 \\
\hline 998 & 0.38 & 0.0336 & -0.8423 \\
\hline 1003 & 0.37 & -0.1780 & -0.3945 \\
\hline 1008 & 0.38 & -0.3896 & 0.0534 \\
\hline 1013 & 0.39 & -0.5131 & 0.1334 \\
\hline 1018 & 0.38 & -0.5778 & -0.0317 \\
\hline 1023 & 0.32 & -0.6424 & -0.1969 \\
\hline 1028 & 0.22 & -0.7071 & -0.3621 \\
\hline 1033 & 0.1 & -0.7718 & -0.5272 \\
\hline 1038 & -0.03 & -0.8365 & -0.6924 \\
\hline 1043 & -0.15 & -0.3781 & -0.6927 \\
\hline 1048 & -0.24 & 0.0804 & -0.6930 \\
\hline 1053 & -0.26 & 0.2967 & -0.7056 \\
\hline 1058 & -0.18 & 0.3516 & -0.7263 \\
\hline 1063 & -0.04 & 0.4065 & -0.7471 \\
\hline 1068 & 0.12 & 0.4614 & -0.7678 \\
\hline 1073 & 0.25 & 0.5163 & -0.7886 \\
\hline 1078 & 0.34 & 0.2341 & -0.7761 \\
\hline 1083 & 0.36 & -0.1324 & -0.7554 \\
\hline 1088 & 0.33 & -0.3240 & -0.7612 \\
\hline 1093 & 0.26 & -0.2533 & -0.8069 \\
\hline 1098 & 0.18 & -0.1825 & -0.8527 \\
\hline 1103 & 0.12 & -0.1117 & -0.8984 \\
\hline 1108 & 0.1 & -0.0410 & -0.9441 \\
\hline 1113 & 0.11 & 0.1050 & -0.9613 \\
\hline 1118 & 0.14 & 0.3012 & -0.9594 \\
\hline 1123 & 0.17 & 0.4444 & -0.9544 \\
\hline 1128 & 0.22 & 0.3760 & -0.9367 \\
\hline 1133 & 0.27 & 0.3077 & -0.9190 \\
\hline 1138 & 0.33 & 0.2393 & -0.9014 \\
\hline 1143 & 0.37 & 0.1710 & -0.8837 \\
\hline 1148 & 0.39 & 0.1026 & -0.8660 \\
\hline 1153 & 0.37 & 0.0886 & -0.7770 \\
\hline 1158 & 0.31 & 0.1559 & -0.5809 \\
\hline 1163 & 0.22 & 0.2232 & -0.3848 \\
\hline 1168 & 0.1 & 0.2864 & -0.2122 \\
\hline 1173 & -0.01 & 0.3327 & -0.1336 \\
\hline 1178 & -0.06 & 0.3791 & -0.0551 \\
\hline 1183 & -0.06 & 0.4254 & 0.0235 \\
\hline 1188 & -0.01 & 0.2794 & 0.2043 \\
\hline 1193 & 0.03 & 0.1334 & 0.3852 \\
\hline 1198 & 0.08 & -0.0126 & 0.5661 \\
\hline
\end{tabular}




\begin{tabular}{|c|c|c|c|}
\hline Cal. yr BP & TSI & Aulacoseira & Pseudostaurosira \\
\hline 1203 & 0.14 & -0.1586 & 0.7470 \\
\hline 1208 & 0.22 & -0.2221 & 0.7871 \\
\hline 1213 & 0.27 & 0.0441 & 0.2640 \\
\hline 1218 & 0.25 & 0.3104 & -0.2591 \\
\hline 1223 & 0.15 & 0.5766 & -0.7821 \\
\hline 1228 & 0 & 0.2984 & -0.2860 \\
\hline 1233 & -0.16 & 0.0202 & 0.2102 \\
\hline 1238 & -0.26 & -0.2580 & 0.7064 \\
\hline 1243 & -0.3 & -0.5362 & 1.2025 \\
\hline 1248 & -0.31 & -0.8144 & 1.6987 \\
\hline 1253 & -0.33 & -0.7852 & 1.5331 \\
\hline 1258 & -0.38 & -0.7560 & 1.3676 \\
\hline 1263 & -0.47 & -0.7268 & 1.2021 \\
\hline 1268 & -0.6 & -0.6977 & 1.0365 \\
\hline 1273 & -0.77 & -0.5376 & 0.9070 \\
\hline 1278 & -0.97 & -0.3775 & 0.7774 \\
\hline 1283 & -0.97 & -0.2175 & 0.6478 \\
\hline 1288 & -0.97 & -0.1354 & 0.4593 \\
\hline 1293 & -0.97 & -0.0729 & 0.2561 \\
\hline 1298 & -0.83 & -0.0104 & 0.0529 \\
\hline 1303 & -0.64 & 0.2121 & -0.1527 \\
\hline 1308 & -0.46 & 0.5414 & -0.3600 \\
\hline 1313 & -0.31 & 0.8706 & -0.5673 \\
\hline 1318 & -0.2 & 0.9054 & -0.6681 \\
\hline 1323 & -0.14 & 0.9402 & -0.7690 \\
\hline 1328 & -0.11 & 0.9750 & -0.8698 \\
\hline 1333 & -0.11 & 1.0098 & -0.9706 \\
\hline 1338 & -0.13 & 0.9570 & -0.9403 \\
\hline 1343 & -0.17 & 0.5535 & -0.3855 \\
\hline 1348 & -0.22 & 0.1500 & 0.1693 \\
\hline 1353 & -0.22 & -0.2534 & 0.7242 \\
\hline 1358 & -0.15 & -0.2847 & 0.5781 \\
\hline 1363 & -0.06 & -0.3160 & 0.4321 \\
\hline 1368 & -0.01 & -0.3473 & 0.2860 \\
\hline 1373 & -0.03 & -0.3786 & 0.1400 \\
\hline 1378 & -0.1 & -0.4099 & -0.0061 \\
\hline 1383 & -0.17 & -0.4412 & -0.1521 \\
\hline 1388 & -0.15 & -0.3734 & 0.0482 \\
\hline 1393 & -0.03 & -0.2808 & 0.3350 \\
\hline 1398 & 0.13 & -0.1882 & 0.6219 \\
\hline 1403 & 0.26 & -0.0956 & 0.9088 \\
\hline 1408 & 0.31 & -0.0539 & 0.8820 \\
\hline
\end{tabular}




\begin{tabular}{|c|c|c|c|}
\hline Cal. yr BP & TSI & Aulacoseira & Pseudostaurosira \\
\hline 1413 & 0.25 & -0.0460 & 0.6460 \\
\hline 1418 & 0.13 & -0.0381 & 0.4100 \\
\hline 1423 & 0.03 & -0.0303 & 0.1741 \\
\hline 1428 & 0.05 & -0.0224 & -0.0619 \\
\hline 1433 & 0.2 & -0.0145 & -0.2979 \\
\hline 1438 & 0.38 & -0.0067 & -0.5339 \\
\hline 1443 & 0.47 & 0.1871 & -0.5536 \\
\hline 1448 & 0.45 & 0.3809 & -0.5733 \\
\hline 1453 & 0.34 & 0.5746 & -0.5930 \\
\hline 1458 & 0.22 & 0.7684 & -0.6127 \\
\hline 1463 & 0.14 & 0.8442 & -0.6524 \\
\hline 1468 & 0.12 & 0.8414 & -0.7053 \\
\hline 1473 & 0.1 & 0.8387 & -0.7582 \\
\hline 1478 & 0.07 & 0.8359 & -0.8111 \\
\hline 1483 & 0.04 & 0.8332 & -0.8641 \\
\hline 1488 & 0.02 & 0.8304 & -0.9170 \\
\hline 1493 & 0.02 & 0.8276 & -0.9699 \\
\hline 1498 & 0.02 & 0.8249 & -1.0229 \\
\hline 1503 & 0.01 & 0.5664 & -0.6908 \\
\hline 1508 & -0.01 & 0.3079 & -0.3588 \\
\hline 1513 & 0 & 0.0495 & -0.0268 \\
\hline 1518 & 0.03 & -0.2090 & 0.3052 \\
\hline 1523 & 0.05 & -0.4675 & 0.6372 \\
\hline 1528 & 0.05 & -0.7260 & 0.9692 \\
\hline 1533 & 0.01 & -0.9844 & 1.3013 \\
\hline 1538 & -0.05 & -1.0885 & 1.3423 \\
\hline 1543 & -0.12 & -1.0895 & 1.1895 \\
\hline 1548 & -0.15 & -1.0906 & 1.0366 \\
\hline 1553 & -0.12 & -1.0917 & 0.8837 \\
\hline 1558 & -0.03 & -0.8931 & 0.6787 \\
\hline 1563 & 0.08 & 0.1037 & 0.2648 \\
\hline 1568 & 0.14 & -0.0409 & 0.3179 \\
\hline 1573 & 0.17 & -0.1855 & 0.3709 \\
\hline 1578 & 0.2 & -0.3301 & 0.4239 \\
\hline 1583 & 0.26 & -0.4747 & 0.4769 \\
\hline 1588 & 0.34 & -0.6192 & 0.5300 \\
\hline 1593 & 0.4 & -0.7638 & 0.5830 \\
\hline 1598 & 0.39 & -0.9084 & 0.6360 \\
\hline 1603 & 0.33 & -1.0530 & 0.6891 \\
\hline 1608 & 0.29 & -0.8193 & 0.5479 \\
\hline 1613 & 0.29 & -0.0179 & 0.1153 \\
\hline 1618 & 0.34 & 0.5945 & -0.2163 \\
\hline
\end{tabular}




\begin{tabular}{|c|c|c|c|}
\hline Cal. yr BP & TSI & Aulacoseira & Pseudostaurosira \\
\hline 1623 & 0.38 & 0.4513 & -0.1446 \\
\hline 1628 & 0.38 & 0.3082 & -0.0728 \\
\hline 1633 & 0.39 & 0.1651 & -0.0011 \\
\hline 1638 & 0.46 & 0.0219 & 0.0707 \\
\hline 1643 & 0.6 & -0.1212 & 0.1424 \\
\hline 1648 & 0.74 & -0.2643 & 0.2142 \\
\hline 1653 & 0.8 & -0.4075 & 0.2859 \\
\hline 1658 & 0.77 & -0.5506 & 0.3576 \\
\hline 1663 & 0.66 & -0.6937 & 0.4294 \\
\hline 1668 & 0.53 & -0.6130 & 0.5288 \\
\hline 1673 & 0.42 & -0.3831 & 0.6466 \\
\hline 1678 & 0.33 & -0.3708 & 0.5910 \\
\hline 1683 & 0.21 & -0.3585 & 0.5353 \\
\hline 1688 & 0.07 & -0.3462 & 0.4797 \\
\hline 1693 & -0.08 & -0.3339 & 0.4240 \\
\hline 1698 & -0.21 & -0.3216 & 0.3684 \\
\hline 1703 & -0.26 & -0.3093 & 0.3127 \\
\hline 1708 & -0.21 & -0.2970 & 0.2571 \\
\hline 1713 & -0.11 & -0.2848 & 0.2014 \\
\hline 1718 & 0.01 & -0.2725 & 0.1458 \\
\hline 1723 & 0.12 & -0.2602 & 0.0901 \\
\hline 1728 & 0.22 & -0.0813 & 0.0141 \\
\hline 1733 & 0.32 & 0.2086 & -0.0754 \\
\hline 1738 & 0.42 & 0.4985 & -0.1648 \\
\hline 1743 & 0.49 & 0.7884 & -0.2543 \\
\hline 1748 & 0.48 & 1.0784 & -0.3438 \\
\hline 1753 & 0.4 & 1.3683 & -0.4333 \\
\hline 1758 & 0.25 & 1.6582 & -0.5228 \\
\hline 1763 & 0.12 & 1.9481 & -0.6123 \\
\hline 1768 & 0.09 & 1.6823 & -0.5151 \\
\hline 1773 & 0.17 & 1.2775 & -0.3712 \\
\hline 1778 & 0.29 & 0.8727 & -0.2274 \\
\hline 1783 & 0.38 & 0.4679 & -0.0835 \\
\hline 1788 & 0.39 & 0.0631 & 0.0604 \\
\hline 1793 & 0.34 & -0.3416 & 0.2043 \\
\hline 1798 & 0.27 & -0.4555 & 0.3233 \\
\hline 1803 & 0.23 & -0.4966 & 0.4362 \\
\hline 1808 & 0.24 & -0.5377 & 0.5490 \\
\hline 1813 & 0.3 & -0.5788 & 0.6618 \\
\hline 1818 & 0.34 & -0.6198 & 0.7747 \\
\hline 1823 & 0.33 & -0.6609 & 0.8875 \\
\hline 1828 & 0.23 & -0.7020 & 1.0004 \\
\hline
\end{tabular}




\begin{tabular}{|c|c|c|c|}
\hline Cal. yr BP & TSI & Aulacoseira & Pseudostaurosira \\
\hline 1833 & 0.05 & -0.7185 & 0.9793 \\
\hline 1838 & -0.17 & -0.6980 & 0.7574 \\
\hline 1843 & -0.37 & -0.6775 & 0.5355 \\
\hline 1848 & -0.49 & -0.6569 & 0.3136 \\
\hline 1853 & -0.42 & -0.6364 & 0.0916 \\
\hline 1858 & -0.2 & -0.4027 & 0.0344 \\
\hline 1863 & 0.06 & -0.1157 & 0.0184 \\
\hline 1868 & 0.28 & 0.1714 & 0.0024 \\
\hline 1873 & 0.4 & 0.4584 & -0.0136 \\
\hline 1878 & 0.4 & 0.7454 & -0.0296 \\
\hline 1883 & 0.29 & 1.0325 & -0.0457 \\
\hline 1888 & 0.12 & 0.8714 & -0.0752 \\
\hline 1893 & -0.06 & 0.5983 & -0.1082 \\
\hline 1898 & -0.19 & 0.3251 & -0.1412 \\
\hline 1903 & -0.24 & 0.0520 & -0.1741 \\
\hline 1908 & -0.22 & -0.2211 & -0.2071 \\
\hline 1913 & -0.13 & -0.4942 & -0.2401 \\
\hline 1918 & 0 & -0.4547 & -0.2219 \\
\hline 1923 & 0.14 & -0.3370 & -0.1909 \\
\hline 1928 & 0.26 & -0.2193 & -0.1599 \\
\hline 1933 & 0.36 & -0.1016 & -0.1289 \\
\hline 1938 & 0.43 & 0.0160 & -0.0979 \\
\hline 1943 & 0.48 & 0.1337 & -0.0669 \\
\hline 1948 & 0.48 & 0.2514 & -0.0359 \\
\hline 1953 & 0.42 & 0.3691 & -0.0049 \\
\hline 1958 & 0.31 & 0.4868 & 0.0262 \\
\hline 1963 & 0.2 & 0.6045 & 0.0572 \\
\hline 1968 & 0.14 & 0.6376 & 0.1141 \\
\hline 1973 & 0.16 & 0.3323 & 0.2750 \\
\hline 1978 & 0.21 & 0.0270 & 0.4359 \\
\hline 1983 & 0.29 & -0.2035 & 0.5712 \\
\hline 1988 & 0.34 & -0.1352 & 0.6043 \\
\hline 1993 & 0.37 & -0.0668 & 0.6373 \\
\hline 1998 & 0.37 & -0.0293 & 0.6795 \\
\hline 2003 & 0.33 & -0.1155 & 0.7580 \\
\hline 2008 & 0.24 & -0.2017 & 0.8365 \\
\hline 2013 & 0.14 & -0.2878 & 0.9150 \\
\hline 2018 & 0.06 & -0.3740 & 0.9934 \\
\hline 2023 & 0.04 & -0.4602 & 1.0719 \\
\hline 2028 & 0.07 & -0.5464 & 1.1504 \\
\hline 2033 & 0.15 & -0.6325 & 1.2289 \\
\hline 2038 & 0.24 & -0.7187 & 1.3074 \\
\hline
\end{tabular}


Appendix E. Diatom and TSI data for time-series analysis

\begin{tabular}{|c|c|c|c|}
\hline Cal. yr BP & TSI & Aulacoseira & Pseudostaurosira \\
\hline 2043 & 0.3 & -0.8049 & 1.3859 \\
\hline 2048 & 0.32 & -0.8087 & 1.3625 \\
\hline 2053 & 0.27 & -0.7919 & 1.3137 \\
\hline 2058 & 0.17 & -0.7751 & 1.2648 \\
\hline 2063 & 0.08 & -0.7583 & 1.2159 \\
\hline 2068 & 0.06 & -0.7415 & 1.1670 \\
\hline 2073 & 0.11 & -0.7247 & 1.1182 \\
\hline 2078 & 0.21 & -0.7079 & 1.0693 \\
\hline 2083 & 0.28 & -0.6910 & 1.0204 \\
\hline 2088 & 0.31 & -0.6742 & 0.9716 \\
\hline 2093 & 0.27 & -0.6574 & 0.9227 \\
\hline 2098 & 0.22 & -0.7146 & 0.7024 \\
\hline 2103 & 0.16 & -0.8211 & 0.3677 \\
\hline 2108 & 0.12 & -0.9276 & 0.0331 \\
\hline 2113 & 0.11 & -0.8508 & 0.4032 \\
\hline 2118 & 0.14 & -0.7741 & 0.7733 \\
\hline 2123 & 0.18 & -0.7463 & 0.9888 \\
\hline 2128 & 0.2 & -0.7920 & 0.9724 \\
\hline 2133 & 0.18 & -0.8376 & 0.9560 \\
\hline 2138 & 0.13 & -0.8833 & 0.9396 \\
\hline 2143 & 0.11 & -0.9290 & 0.9231 \\
\hline 2148 & 0.13 & -0.9746 & 0.9067 \\
\hline 2153 & 0.21 & -1.0203 & 0.8903 \\
\hline 2158 & 0.33 & -1.0660 & 0.8739 \\
\hline 2163 & 0.45 & -1.1116 & 0.8574 \\
\hline 2168 & 0.55 & -1.1573 & 0.8410 \\
\hline 2173 & 0.63 & -1.1661 & 0.8198 \\
\hline 2178 & 0.64 & -1.0272 & 0.7794 \\
\hline 2183 & 0.59 & -0.8884 & 0.7390 \\
\hline 2188 & 0.48 & -0.7495 & 0.6986 \\
\hline 2193 & 0.34 & -0.6107 & 0.6581 \\
\hline 2198 & 0.22 & -0.4718 & 0.6177 \\
\hline 2203 & 0.13 & -0.3330 & 0.5773 \\
\hline 2208 & 0.06 & -0.1942 & 0.5369 \\
\hline 2213 & 0 & -0.0553 & 0.4965 \\
\hline 2218 & 0 & -0.0181 & 0.5119 \\
\hline 2223 & 0.08 & -0.3872 & 0.7504 \\
\hline 2228 & 0.23 & -0.7563 & 0.9889 \\
\hline 2233 & 0.38 & -0.8358 & 1.0360 \\
\hline 2238 & 0.46 & -0.7222 & 0.9555 \\
\hline 2243 & 0.47 & -0.6087 & 0.8750 \\
\hline 2248 & 0.42 & -0.4951 & 0.7945 \\
\hline
\end{tabular}




\begin{tabular}{|c|c|c|c|}
\hline Cal. yr BP & TSI & Aulacoseira & Pseudostaurosira \\
\hline 2253 & 0.36 & -0.3815 & 0.7140 \\
\hline 2258 & 0.3 & -0.2680 & 0.6335 \\
\hline 2263 & 0.21 & -0.1544 & 0.5530 \\
\hline 2268 & 0.11 & -0.0409 & 0.4725 \\
\hline 2273 & 0.04 & 0.0727 & 0.3920 \\
\hline 2278 & 0.06 & -0.5954 & 0.7531 \\
\hline 2283 & 0.15 & -1.3223 & 1.1511 \\
\hline 2288 & 0.25 & -1.3558 & 1.1628 \\
\hline 2293 & 0.27 & -1.3892 & 1.1745 \\
\hline 2298 & 0.17 & -1.4227 & 1.1863 \\
\hline 2303 & -0.02 & -1.4561 & 1.1980 \\
\hline 2308 & -0.23 & -1.4896 & 1.2097 \\
\hline 2313 & -0.39 & -1.5230 & 1.2215 \\
\hline 2318 & -0.46 & -1.5565 & 1.2332 \\
\hline 2323 & -0.46 & -1.5899 & 1.2449 \\
\hline 2328 & -0.42 & -1.6234 & 1.2567 \\
\hline 2333 & -0.35 & -1.6568 & 1.2684 \\
\hline 2338 & -0.28 & -1.6903 & 1.2801 \\
\hline 2343 & -0.23 & -1.7237 & 1.2919 \\
\hline 2348 & -0.19 & -1.5617 & 1.2386 \\
\hline 2353 & -0.18 & -1.2694 & 1.1420 \\
\hline 2358 & -0.16 & -0.9771 & 1.0454 \\
\hline 2363 & -0.14 & -0.6848 & 0.9487 \\
\hline 2368 & -0.12 & -0.3924 & 0.8521 \\
\hline 2373 & -0.07 & -0.1001 & 0.7555 \\
\hline 2378 & 0.01 & 0.1922 & 0.6589 \\
\hline 2383 & 0.14 & 0.4845 & 0.5623 \\
\hline 2388 & 0.29 & 0.7769 & 0.4656 \\
\hline 2393 & 0.4 & 1.0692 & 0.3690 \\
\hline 2398 & 0.44 & 0.8703 & 0.5960 \\
\hline 2403 & 0.43 & 0.5486 & 0.9038 \\
\hline 2408 & 0.41 & 0.2269 & 1.2116 \\
\hline 2413 & 0.43 & -0.0948 & 1.5195 \\
\hline 2418 & 0.51 & -0.4164 & 1.8273 \\
\hline 2423 & 0.59 & -0.7348 & 1.9748 \\
\hline 2428 & 0.61 & -1.0397 & 1.4810 \\
\hline 2433 & 0.55 & -1.2955 & 1.0927 \\
\hline 2438 & 0.44 & -1.3546 & 1.1263 \\
\hline 2443 & 0.31 & -1.4137 & 1.1598 \\
\hline 2448 & 0.21 & -1.4728 & 1.1934 \\
\hline 2453 & 0.17 & -1.5319 & 1.2270 \\
\hline 2458 & 0.19 & -1.5910 & 1.2606 \\
\hline
\end{tabular}




\begin{tabular}{|c|c|c|c|}
\hline Cal. yr BP & TSI & Aulacoseira & Pseudostaurosira \\
\hline 2463 & 0.26 & -1.6501 & 1.2942 \\
\hline 2468 & 0.34 & -1.7091 & 1.3278 \\
\hline 2473 & 0.4 & -1.7682 & 1.3614 \\
\hline 2478 & 0.4 & -1.8273 & 1.3950 \\
\hline 2483 & 0.33 & -1.8864 & 1.4285 \\
\hline 2488 & 0.24 & -1.9455 & 1.4621 \\
\hline 2493 & 0.17 & -2.0046 & 1.4957 \\
\hline 2498 & 0.12 & -2.0637 & 1.5293 \\
\hline 2503 & 0.07 & -2.1227 & 1.5629 \\
\hline 2508 & -0.02 & -2.1818 & 1.5965 \\
\hline 2513 & -0.13 & -2.2409 & 1.6301 \\
\hline 2518 & -0.16 & -2.3000 & 1.6636 \\
\hline 2523 & -0.06 & -0.8111 & 1.0261 \\
\hline 2528 & 0.12 & 0.6779 & 0.3886 \\
\hline 2533 & 0.29 & 0.5940 & 0.4135 \\
\hline 2538 & 0.4 & 0.5102 & 0.4384 \\
\hline 2543 & 0.44 & 0.4263 & 0.4633 \\
\hline 2548 & 0.47 & 0.3425 & 0.4882 \\
\hline 2553 & 0.49 & 0.2586 & 0.5131 \\
\hline 2558 & 0.5 & 0.1748 & 0.5380 \\
\hline 2563 & 0.46 & 0.0909 & 0.5629 \\
\hline 2568 & 0.37 & 0.0071 & 0.5878 \\
\hline 2573 & 0.27 & -0.0768 & 0.6127 \\
\hline 2578 & 0.21 & -0.1606 & 0.6376 \\
\hline 2583 & 0.18 & -0.2445 & 0.6625 \\
\hline 2588 & 0.17 & -0.3284 & 0.6874 \\
\hline 2593 & 0.18 & -0.4122 & 0.7123 \\
\hline 2598 & 0.22 & -0.4961 & 0.7372 \\
\hline 2603 & 0.3 & -0.5799 & 0.7621 \\
\hline 2608 & 0.39 & -0.5879 & 0.8067 \\
\hline 2613 & 0.41 & -0.5453 & 0.8643 \\
\hline 2618 & 0.33 & -0.5028 & 0.9220 \\
\hline 2623 & 0.12 & -0.4602 & 0.9797 \\
\hline 2628 & -0.14 & -0.4176 & 1.0373 \\
\hline 2633 & -0.35 & -0.3751 & 1.0950 \\
\hline 2638 & -0.41 & -0.3325 & 1.1526 \\
\hline 2643 & -0.33 & -0.2899 & 1.2103 \\
\hline 2648 & -0.18 & -0.2473 & 1.2680 \\
\hline 2653 & -0.01 & -0.2500 & 1.3198 \\
\hline 2658 & 0.18 & -0.4336 & 1.3486 \\
\hline 2663 & 0.34 & -0.6173 & 1.3774 \\
\hline 2668 & 0.43 & -0.8009 & 1.4061 \\
\hline
\end{tabular}




\begin{tabular}{|c|c|c|c|}
\hline Cal. yr BP & TSI & Aulacoseira & Pseudostaurosira \\
\hline 2673 & 0.4 & -0.9845 & 1.4349 \\
\hline 2678 & 0.22 & -1.1681 & 1.4636 \\
\hline 2683 & -0.05 & -1.3517 & 1.4924 \\
\hline 2688 & -0.32 & -1.5354 & 1.5211 \\
\hline 2693 & -0.48 & -1.5815 & 1.5096 \\
\hline 2698 & -0.48 & -1.4215 & 1.4375 \\
\hline 2703 & -0.43 & -1.2615 & 1.3655 \\
\hline 2708 & -0.4 & -1.1014 & 1.2935 \\
\hline 2713 & -0.41 & -0.9414 & 1.2214 \\
\hline 2718 & -0.42 & -0.7814 & 1.1494 \\
\hline 2723 & -0.4 & -0.6213 & 1.0774 \\
\hline 2728 & -0.39 & -0.4613 & 1.0053 \\
\hline 2733 & -0.41 & -0.3013 & 0.9333 \\
\hline 2738 & -0.49 & -0.1412 & 0.8612 \\
\hline 2743 & -0.57 & 0.0188 & 0.7892 \\
\hline 2748 & -0.62 & 0.1788 & 0.7172 \\
\hline 2753 & -0.63 & -0.2669 & 0.9062 \\
\hline 2758 & -0.65 & -0.7126 & 1.0952 \\
\hline 2763 & -0.69 & -1.1584 & 1.2842 \\
\hline 2768 & -0.7 & -1.6041 & 1.4732 \\
\hline 2773 & -0.62 & -2.0498 & 1.6622 \\
\hline 2778 & -0.47 & -2.3417 & 1.7494 \\
\hline 2783 & -0.31 & -2.0181 & 1.4294 \\
\hline 2788 & -0.18 & -1.6946 & 1.1094 \\
\hline 2793 & -0.11 & -1.3710 & 0.7894 \\
\hline 2798 & -0.08 & -1.1786 & 0.6051 \\
\hline 2803 & -0.05 & -1.1831 & 0.6243 \\
\hline 2808 & 0.01 & -1.1876 & 0.6434 \\
\hline 2813 & 0.1 & -1.1921 & 0.6626 \\
\hline 2818 & 0.25 & -1.1966 & 0.6818 \\
\hline 2823 & 0.43 & -1.2011 & 0.7009 \\
\hline 2828 & 0.59 & -1.2055 & 0.7201 \\
\hline 2833 & 0.67 & -1.2100 & 0.7392 \\
\hline 2838 & 0.63 & -1.2145 & 0.7584 \\
\hline 2843 & 0.48 & -1.2190 & 0.7776 \\
\hline 2848 & 0.26 & -1.2235 & 0.7967 \\
\hline 2853 & 0.08 & -1.2279 & 0.8159 \\
\hline 2858 & 0.02 & -1.2324 & 0.8351 \\
\hline 2863 & 0.04 & -1.1840 & 0.8479 \\
\hline 2868 & 0.04 & -1.1356 & 0.8607 \\
\hline 2873 & -0.05 & -1.0872 & 0.8735 \\
\hline 2878 & -0.19 & -1.0388 & 0.8863 \\
\hline
\end{tabular}




\begin{tabular}{|c|c|c|c|}
\hline Cal. yr BP & TSI & Aulacoseira & Pseudostaurosira \\
\hline 2883 & -0.25 & -0.9904 & 0.8991 \\
\hline 2888 & -0.13 & -0.9420 & 0.9119 \\
\hline 2893 & 0.09 & -0.8936 & 0.9247 \\
\hline 2898 & 0.25 & -0.8452 & 0.9375 \\
\hline 2903 & 0.28 & -0.7968 & 0.9503 \\
\hline 2908 & 0.19 & -0.7483 & 0.9631 \\
\hline 2913 & 0.09 & -0.6999 & 0.9759 \\
\hline 2918 & 0.05 & -0.6515 & 0.9887 \\
\hline 2923 & 0.1 & -0.6031 & 1.0015 \\
\hline 2928 & 0.13 & -0.5842 & 1.0082 \\
\hline 2933 & 0.07 & -0.6831 & 0.9902 \\
\hline 2938 & -0.1 & -0.7819 & 0.9722 \\
\hline 2943 & -0.33 & -0.8808 & 0.9542 \\
\hline 2948 & -0.53 & -0.9797 & 0.9362 \\
\hline 2953 & -0.6 & -1.0786 & 0.9182 \\
\hline 2958 & -0.6 & -1.0247 & 0.8979 \\
\hline 2963 & -0.59 & -0.9708 & 0.8776 \\
\hline 2968 & -0.59 & -0.9169 & 0.8573 \\
\hline 2973 & -0.53 & -0.8630 & 0.8369 \\
\hline 2978 & -0.39 & -0.8091 & 0.8166 \\
\hline 2983 & -0.21 & -0.7552 & 0.7963 \\
\hline 2988 & -0.04 & -0.7012 & 0.7760 \\
\hline 2993 & 0.1 & -0.6473 & 0.7557 \\
\hline 2998 & 0.18 & -0.5934 & 0.7353 \\
\hline 3003 & 0.2 & -0.5395 & 0.7150 \\
\hline 3008 & 0.18 & -0.4856 & 0.6947 \\
\hline 3013 & 0.11 & -0.4317 & 0.6744 \\
\hline 3018 & 0.04 & -0.3778 & 0.6541 \\
\hline 3023 & -0.02 & -0.3239 & 0.6338 \\
\hline 3028 & -0.07 & -0.2700 & 0.6134 \\
\hline 3033 & -0.11 & -0.4195 & 0.6989 \\
\hline 3038 & -0.15 & -0.8741 & 0.9431 \\
\hline 3043 & -0.17 & -1.3287 & 1.1873 \\
\hline 3048 & -0.15 & -1.7834 & 1.4316 \\
\hline 3053 & -0.1 & -2.2380 & 1.6758 \\
\hline 3058 & -0.06 & -2.5890 & 1.8750 \\
\hline 3063 & -0.04 & -2.5254 & 1.8946 \\
\hline 3068 & -0.05 & -2.4617 & 1.9142 \\
\hline 3073 & -0.04 & -2.3981 & 1.9338 \\
\hline 3078 & 0.01 & -2.3345 & 1.9534 \\
\hline 3083 & 0.07 & -2.2709 & 1.9730 \\
\hline 3088 & 0.11 & -2.2072 & 1.9926 \\
\hline
\end{tabular}




\begin{tabular}{|c|c|c|c|}
\hline Cal. yr BP & TSI & Aulacoseira & Pseudostaurosira \\
\hline 3093 & 0.14 & -2.1436 & 2.0122 \\
\hline 3098 & 0.16 & -2.0800 & 2.0318 \\
\hline 3103 & 0.19 & -2.0164 & 2.0514 \\
\hline 3108 & 0.21 & -1.9527 & 2.0710 \\
\hline 3113 & 0.22 & -1.8891 & 2.0906 \\
\hline 3118 & 0.18 & -1.8255 & 2.1102 \\
\hline 3123 & 0.12 & -1.7844 & 2.0095 \\
\hline 3128 & 0.08 & -1.7432 & 1.9088 \\
\hline 3133 & 0.08 & -1.7021 & 1.8081 \\
\hline 3138 & 0.1 & -1.6610 & 1.7074 \\
\hline 3143 & 0.11 & -1.6199 & 1.6066 \\
\hline 3148 & 0.07 & -1.5788 & 1.5059 \\
\hline 3153 & -0.01 & -1.5377 & 1.4052 \\
\hline 3158 & -0.13 & -1.4966 & 1.3045 \\
\hline 3163 & -0.23 & -1.4311 & 1.2346 \\
\hline 3168 & -0.26 & -1.3293 & 1.2108 \\
\hline 3173 & -0.21 & -1.2274 & 1.1871 \\
\hline 3178 & -0.12 & -1.1256 & 1.1633 \\
\hline 3183 & -0.05 & -1.0237 & 1.1396 \\
\hline 3188 & -0.01 & -0.9219 & 1.1158 \\
\hline 3193 & 0.04 & -0.8200 & 1.0921 \\
\hline 3198 & 0.11 & -0.7182 & 1.0683 \\
\hline 3203 & 0.21 & -0.6163 & 1.0446 \\
\hline 3208 & 0.29 & -0.5145 & 1.0208 \\
\hline 3213 & 0.3 & -0.4126 & 0.9971 \\
\hline 3218 & 0.25 & -0.5073 & 0.9935 \\
\hline 3223 & 0.16 & -0.6020 & 0.9899 \\
\hline 3228 & 0.11 & -0.6967 & 0.9863 \\
\hline 3233 & 0.12 & -0.7913 & 0.9827 \\
\hline 3238 & 0.18 & -0.8860 & 0.9791 \\
\hline 3243 & 0.25 & -0.9807 & 0.9755 \\
\hline 3248 & 0.28 & -1.0754 & 0.9719 \\
\hline 3253 & 0.25 & -1.1701 & 0.9683 \\
\hline 3258 & 0.15 & -1.2648 & 0.9647 \\
\hline 3263 & 0.01 & -1.2672 & 0.9920 \\
\hline 3268 & -0.12 & -1.1313 & 1.0657 \\
\hline 3273 & -0.19 & -0.9953 & 1.1393 \\
\hline 3278 & -0.15 & -0.8594 & 1.2130 \\
\hline 3283 & -0.06 & -0.7234 & 1.2867 \\
\hline 3288 & 0.04 & -0.5875 & 1.3603 \\
\hline 3293 & 0.12 & -0.4516 & 1.4340 \\
\hline 3298 & 0.2 & -0.3791 & 1.5230 \\
\hline
\end{tabular}


Appendix E. Diatom and TSI data for time-series analysis

\begin{tabular}{llll}
\hline Cal. yr BP & TSI & Aulacoseira & Pseudostaurosira \\
\hline 3303 & 0.27 & -0.5606 & 1.6733 \\
3308 & 0.31 & -0.7421 & 1.8236 \\
3313 & 0.27 & -0.9236 & 1.9740 \\
3318 & 0.15 & -1.1051 & 2.1243 \\
3323 & -0.04 & -1.2865 & 2.2746 \\
3328 & -0.22 & -1.4680 & 2.4250 \\
3333 & -0.32 & -1.6495 & 2.5753
\end{tabular}




\section{Appendix F. Age-depth information for the Danny's Lake sediment core}

Age-depth information for the Danny's Lake core based on 25 radiocarbon dates and the age depth model constructed in Bacon. All dates are shown in calibrated years before present (AD 1950) and the maximum probability (MAP) was used for assigning ages to proxy data. 


\begin{tabular}{rrrr}
\hline Depth (cm) & min & max & MAP \\
0 & -254 & 146 & -68.4 \\
0.1 & -205 & 145 & -61.6 \\
0.2 & -197 & 153 & -54.8 \\
0.3 & -193 & 152 & -48 \\
0.4 & -185 & 155 & -41.2 \\
0.5 & -176 & 159 & -34.4 \\
0.6 & -173 & 162 & -27.5 \\
0.7 & -164 & 166 & -20.7 \\
0.8 & -266 & 164 & -13.9 \\
0.9 & -257 & 168 & -7.1 \\
1 & -249 & 171 & -0.3 \\
1.1 & -240 & 175 & 6.5 \\
1.2 & -232 & 188 & 13.3 \\
1.3 & -223 & 192 & 20.2 \\
1.4 & -215 & 185 & 27 \\
1.5 & -206 & 189 & 33.8 \\
1.6 & -198 & 192 & 40.6 \\
1.7 & -189 & 196 & 47.4 \\
1.8 & -180 & 200 & 54.2 \\
1.9 & -172 & 203 & 61 \\
2 & -163 & 207 & 67.9 \\
2.1 & -155 & 210 & 74.7 \\
2.2 & -146 & 214 & 81.5 \\
2.3 & -138 & 212 & 88.3 \\
2.4 & -129 & 216 & 95.1 \\
2.5 & -121 & 224 & 101.9 \\
2.6 & -113 & 227 & 108.7 \\
2.7 & -105 & 230 & 115.6 \\
2.8 & -96 & 229 & 122.4 \\
2.9 & -88 & 232 & 129.2 \\
3 & -80 & 235 & 136 \\
3.1 & -72 & 243 & 142.8 \\
3.2 & -63 & 242 & 149.6 \\
3.3 & -55 & 245 & 156.4 \\
3.4 & -47 & 253 & 163.3 \\
3.5 & -39 & 256 & 170.1 \\
3.6 & -30 & 260 & 176.9 \\
3.7 & -22 & 258 & 183.7 \\
3.8 & -14 & 266 & 190.5 \\
3.9 & -6 & 269 & 197.3 \\
4 & 3 & 273 & 204.1
\end{tabular}

\begin{tabular}{rrrr}
\hline Depth (cm) & min & max & MAP \\
\hline 4.1 & 11 & 276 & 211 \\
4.2 & 19 & 279 & 217.8 \\
4.3 & 27 & 282 & 224.6 \\
4.4 & 36 & 286 & 231.4 \\
4.5 & 44 & 284 & 238.2 \\
4.6 & 52 & 287 & 245 \\
4.7 & 75 & 290 & 251.8 \\
4.8 & 69 & 299 & 258.6 \\
4.9 & 77 & 302 & 265.5 \\
5 & 85 & 305 & 272.3 \\
5.1 & 98 & 318 & 276.5 \\
5.2 & 102 & 312 & 280.7 \\
5.3 & 115 & 315 & 285 \\
5.4 & 128 & 328 & 289.2 \\
5.5 & 131 & 326 & 293.4 \\
5.6 & 135 & 335 & 297.7 \\
5.7 & 143 & 333 & 301.9 \\
5.8 & 151 & 336 & 306.1 \\
5.9 & 159 & 339 & 310.3 \\
6 & 167 & 342 & 314.6 \\
6.1 & 173 & 348 & 318.8 \\
6.2 & 181 & 356 & 323 \\
6.3 & 190 & 360 & 327.3 \\
6.4 & 193 & 363 & 331.5 \\
6.5 & 202 & 367 & 335.7 \\
6.6 & 211 & 371 & 339.9 \\
6.7 & 219 & 369 & 344.2 \\
6.8 & 223 & 378 & 348.4 \\
6.9 & 246 & 386 & 352.6 \\
7 & 235 & 385 & 356.9 \\
7.1 & 258 & 388 & 361.1 \\
7.2 & 267 & 392 & 365.3 \\
7.3 & 275 & 400 & 369.5 \\
7.4 & 284 & 404 & 373.8 \\
7.5 & 292 & 407 & 378 \\
7.6 & 301 & 416 & 382.2 \\
7.7 & 309 & 419 & 386.5 \\
7.8 & 313 & 423 & 390.7 \\
7.9 & 317 & 427 & 394.9 \\
8 & 325 & 435 & 399.1 \\
8.1 & 334 & 439 & 403.4
\end{tabular}




\begin{tabular}{rrrr}
\hline Depth (cm) & min & max & MAP \\
\hline 8.2 & 347 & 442 & 407.6 \\
8.3 & 346 & 446 & 411.8 \\
8.4 & 364 & 454 & 416.1 \\
8.5 & 373 & 458 & 420.3 \\
8.6 & 376 & 456 & 424.5 \\
8.7 & 385 & 465 & 428.7 \\
8.8 & 393 & 468 & 433 \\
8.9 & 397 & 477 & 437.2 \\
9 & 400 & 480 & 441.4 \\
9.1 & 414 & 484 & 445.7 \\
9.2 & 418 & 488 & 449.9 \\
9.3 & 421 & 491 & 454.1 \\
9.4 & 425 & 495 & 458.3 \\
9.5 & 433 & 503 & 462.6 \\
9.6 & 437 & 507 & 466.8 \\
9.7 & 440 & 510 & 471 \\
9.8 & 444 & 514 & 475.3 \\
9.9 & 447 & 522 & 479.5 \\
10 & 451 & 526 & 483.7 \\
10.1 & 460 & 530 & 489.5 \\
10.2 & 464 & 534 & 495.2 \\
10.3 & 473 & 543 & 501 \\
10.4 & 477 & 547 & 506.8 \\
10.5 & 486 & 551 & 512.5 \\
10.6 & 490 & 555 & 518.3 \\
10.7 & 494 & 559 & 524.1 \\
10.8 & 498 & 568 & 529.8 \\
10.9 & 512 & 572 & 535.6 \\
11 & 511 & 576 & 541.3 \\
11.1 & 515 & 580 & 547.1 \\
11.2 & 524 & 584 & 552.9 \\
11.3 & 528 & 588 & 558.6 \\
11.4 & 537 & 597 & 564.4 \\
11.5 & 541 & 601 & 570.2 \\
11.6 & 545 & 605 & 575.9 \\
11.7 & 554 & 614 & 581.7 \\
11.8 & 558 & 618 & 587.5 \\
11.9 & 562 & 622 & 593.2 \\
12 & 566 & 626 & 599 \\
12.1 & 575 & 635 & 604.7 \\
12.2 & 579 & 639 & 610.5 \\
& & &
\end{tabular}

\begin{tabular}{rrrr}
\hline Depth (cm) & min & max & MAP \\
\hline 12.3 & 583 & 648 & 616.3 \\
12.4 & 587 & 652 & 622 \\
12.5 & 591 & 656 & 627.8 \\
12.6 & 600 & 665 & 633.6 \\
12.7 & 599 & 669 & 639.3 \\
12.8 & 608 & 678 & 645.1 \\
12.9 & 611 & 681 & 650.8 \\
13 & 616 & 686 & 656.6 \\
13.1 & 621 & 696 & 662.4 \\
13.2 & 626 & 701 & 668.1 \\
13.3 & 621 & 706 & 673.9 \\
13.4 & 632 & 712 & 679.7 \\
13.5 & 637 & 722 & 685.4 \\
13.6 & 642 & 727 & 691.2 \\
13.7 & 642 & 732 & 697 \\
13.8 & 648 & 738 & 702.7 \\
13.9 & 653 & 743 & 708.5 \\
14 & 658 & 753 & 714.2 \\
14.1 & 663 & 758 & 720 \\
14.2 & 664 & 764 & 725.8 \\
14.3 & 664 & 769 & 731.5 \\
14.4 & 669 & 779 & 737.3 \\
14.5 & 674 & 784 & 743.1 \\
14.6 & 675 & 790 & 748.8 \\
14.7 & 678 & 798 & 754.6 \\
14.8 & 682 & 802 & 760.3 \\
14.9 & 686 & 811 & 766.1 \\
15 & 689 & 814 & 771.9 \\
15.1 & 694 & 819 & 775.5 \\
15.2 & 703 & 828 & 779.1 \\
15.3 & 708 & 828 & 782.8 \\
15.4 & 713 & 833 & 786.4 \\
15.5 & 717 & 837 & 790 \\
15.6 & 722 & 837 & 793.6 \\
15.7 & 726 & 841 & 797.3 \\
15.8 & 736 & 851 & 800.9 \\
15.9 & 736 & 851 & 804.5 \\
16 & 745 & 855 & 808.1 \\
16.1 & 750 & 860 & 811.8 \\
16.2 & 754 & 864 & 815.4 \\
16.3 & 759 & 869 & 819 \\
& & &
\end{tabular}




\begin{tabular}{rrrr}
\hline Depth (cm) & min & max & MAP \\
\hline 16.4 & 763 & 873 & 822.7 \\
16.5 & 768 & 878 & 826.3 \\
16.6 & 773 & 883 & 829.9 \\
16.7 & 777 & 887 & 833.5 \\
16.8 & 777 & 887 & 837.2 \\
16.9 & 791 & 896 & 840.8 \\
17 & 791 & 896 & 844.4 \\
17.1 & 796 & 901 & 848 \\
17.2 & 800 & 910 & 851.7 \\
17.3 & 805 & 920 & 855.3 \\
17.4 & 809 & 919 & 858.9 \\
17.5 & 813 & 923 & 862.6 \\
17.6 & 822 & 932 & 866.2 \\
17.7 & 826 & 936 & 869.8 \\
17.8 & 829 & 944 & 873.4 \\
17.9 & 827 & 942 & 877.1 \\
18 & 831 & 946 & 880.7 \\
18.1 & 844 & 959 & 884.3 \\
18.2 & 842 & 952 & 887.9 \\
18.3 & 845 & 955 & 891.6 \\
18.4 & 853 & 963 & 895.2 \\
18.5 & 851 & 966 & 898.8 \\
18.6 & 854 & 969 & 902.5 \\
18.7 & 862 & 977 & 906.1 \\
18.8 & 865 & 985 & 909.7 \\
18.9 & 873 & 993 & 913.3 \\
19 & 876 & 996 & 917 \\
19.1 & 879 & 1004 & 920.6 \\
19.2 & 882 & 1007 & 924.2 \\
19.3 & 885 & 1015 & 927.8 \\
19.4 & 888 & 1018 & 931.5 \\
19.5 & 891 & 1026 & 935.1 \\
19.6 & 894 & 1029 & 938.7 \\
19.7 & 892 & 1032 & 942.4 \\
19.8 & 900 & 1040 & 946 \\
19.9 & 898 & 1043 & 949.6 \\
20 & 902 & 1042 & 953.2 \\
20.1 & 906 & 1046 & 957.3 \\
20.2 & 916 & 1056 & 961.3 \\
20.3 & 920 & 1060 & 965.3 \\
20.4 & 925 & 1055 & 969.3
\end{tabular}

\begin{tabular}{rrrr}
\hline Depth (cm) & min & max & MAP \\
\hline 20.5 & 929 & 1064 & 973.3 \\
20.6 & 934 & 1069 & 977.4 \\
20.7 & 938 & 1063 & 981.4 \\
20.8 & 943 & 1068 & 985.4 \\
20.9 & 943 & 1068 & 989.4 \\
21 & 952 & 1077 & 993.4 \\
21.1 & 957 & 1077 & 997.5 \\
21.2 & 961 & 1081 & 1001.5 \\
21.3 & 961 & 1081 & 1005.5 \\
21.4 & 965 & 1085 & 1009.5 \\
21.5 & 970 & 1090 & 1013.5 \\
21.6 & 980 & 1095 & 1017.5 \\
21.7 & 984 & 1099 & 1021.6 \\
21.8 & 984 & 1099 & 1025.6 \\
21.9 & 988 & 1103 & 1029.6 \\
22 & 998 & 1108 & 1033.6 \\
22.1 & 1002 & 1112 & 1037.6 \\
22.2 & 1002 & 1112 & 1041.7 \\
22.3 & 1005 & 1115 & 1045.7 \\
22.4 & 1013 & 1123 & 1049.7 \\
22.5 & 1015 & 1125 & 1053.7 \\
22.6 & 1017 & 1127 & 1057.7 \\
22.7 & 1020 & 1130 & 1061.8 \\
22.8 & 1022 & 1137 & 1065.8 \\
22.9 & 1030 & 1140 & 1069.8 \\
23 & 1032 & 1142 & 1073.8 \\
23.1 & 1034 & 1149 & 1077.8 \\
23.2 & 1037 & 1152 & 1081.9 \\
23.3 & 1044 & 1154 & 1085.9 \\
23.4 & 1046 & 1161 & 1089.9 \\
23.5 & 1049 & 1164 & 1093.9 \\
23.6 & 1056 & 1166 & 1097.9 \\
23.7 & 1059 & 1174 & 1102 \\
23.8 & 1061 & 1176 & 1106 \\
23.9 & 1063 & 1178 & 1110 \\
24 & 1066 & 1181 & 1114 \\
24.1 & 1073 & 1188 & 1118 \\
24.2 & 1070 & 1190 & 1122 \\
24.3 & 1078 & 1198 & 1126.1 \\
24.4 & 1085 & 1205 & 1130.1 \\
24.5 & 1087 & 1207 & 1134.1
\end{tabular}




\begin{tabular}{rrrr}
\hline Depth (cm) & min & max & MAP \\
\hline 24.6 & 1090 & 1210 & 1138.1 \\
24.7 & 1092 & 1212 & 1142.1 \\
24.8 & 1095 & 1220 & 1146.2 \\
24.9 & 1097 & 1222 & 1150.2 \\
25 & 1104 & 1229 & 1154.2 \\
25.1 & 1099 & 1229 & 1158.3 \\
25.2 & 1113 & 1233 & 1162.3 \\
25.3 & 1113 & 1233 & 1166.3 \\
25.4 & 1123 & 1238 & 1170.4 \\
25.5 & 1122 & 1237 & 1174.4 \\
25.6 & 1127 & 1242 & 1178.5 \\
25.7 & 1131 & 1241 & 1182.5 \\
25.8 & 1136 & 1246 & 1186.6 \\
25.9 & 1140 & 1250 & 1190.6 \\
26 & 1145 & 1255 & 1194.7 \\
26.1 & 1149 & 1254 & 1198.7 \\
26.2 & 1154 & 1259 & 1202.8 \\
26.3 & 1159 & 1264 & 1206.8 \\
26.4 & 1163 & 1263 & 1210.9 \\
26.5 & 1168 & 1268 & 1214.9 \\
26.6 & 1172 & 1267 & 1219 \\
26.7 & 1177 & 1272 & 1223 \\
26.8 & 1181 & 1276 & 1227.1 \\
26.9 & 1186 & 1276 & 1231.1 \\
27 & 1191 & 1281 & 1235.2 \\
27.1 & 1195 & 1285 & 1239.2 \\
27.2 & 1200 & 1290 & 1243.3 \\
27.3 & 1199 & 1289 & 1247.3 \\
27.4 & 1204 & 1294 & 1251.4 \\
27.5 & 1208 & 1293 & 1255.4 \\
27.6 & 1213 & 1298 & 1259.5 \\
27.7 & 1217 & 1302 & 1263.5 \\
27.8 & 1217 & 1302 & 1267.6 \\
27.9 & 1227 & 1307 & 1271.6 \\
28 & 1231 & 1311 & 1275.7 \\
28.1 & 1231 & 1311 & 1279.7 \\
28.2 & 1235 & 1315 & 1283.8 \\
28.3 & 1235 & 1315 & 1287.8 \\
28.4 & 1239 & 1319 & 1291.9 \\
28.5 & 1244 & 1324 & 1295.9 \\
28.6 & 1248 & 1328 & 1300
\end{tabular}

\begin{tabular}{rrrr}
\hline Depth (cm) & min & max & MAP \\
\hline 28.7 & 1253 & 1333 & 1304 \\
28.8 & 1258 & 1338 & 1308.1 \\
28.9 & 1262 & 1342 & 1312.1 \\
29 & 1262 & 1342 & 1316.2 \\
29.1 & 1266 & 1346 & 1320.2 \\
29.2 & 1271 & 1351 & 1324.3 \\
29.3 & 1274 & 1354 & 1328.3 \\
29.4 & 1276 & 1361 & 1332.4 \\
29.5 & 1279 & 1364 & 1336.4 \\
29.6 & 1281 & 1366 & 1340.5 \\
29.7 & 1284 & 1374 & 1344.5 \\
29.8 & 1291 & 1376 & 1348.6 \\
29.9 & 1288 & 1378 & 1352.6 \\
30 & 1296 & 1386 & 1356.7 \\
30.1 & 1298 & 1388 & 1362.1 \\
30.2 & 1305 & 1390 & 1367.5 \\
30.3 & 1312 & 1397 & 1372.9 \\
30.4 & 1324 & 1404 & 1378.3 \\
30.5 & 1326 & 1406 & 1383.7 \\
30.6 & 1333 & 1413 & 1389.2 \\
30.7 & 1340 & 1420 & 1394.6 \\
30.8 & 1347 & 1422 & 1400 \\
30.9 & 1354 & 1429 & 1405.4 \\
31 & 1356 & 1431 & 1410.8 \\
31.1 & 1363 & 1438 & 1416.2 \\
31.2 & 1370 & 1440 & 1421.6 \\
31.3 & 1377 & 1447 & 1427.1 \\
31.4 & 1383 & 1453 & 1432.5 \\
31.5 & 1394 & 1459 & 1437.9 \\
31.6 & 1400 & 1465 & 1443.3 \\
31.7 & 1406 & 1471 & 1448.7 \\
31.8 & 1412 & 1477 & 1454.1 \\
31.9 & 1413 & 1478 & 1459.5 \\
32 & 1419 & 1484 & 1465 \\
32.1 & 1425 & 1490 & 1470.4 \\
32.2 & 1431 & 1496 & 1475.8 \\
32.3 & 1442 & 1502 & 1481.2 \\
32.4 & 1449 & 1509 & 1486.6 \\
32.5 & 1455 & 1515 & 1492 \\
32.6 & 1461 & 1521 & 1497.4 \\
32.7 & 1467 & 1527 & 1502.9
\end{tabular}




\begin{tabular}{rrrr}
\hline Depth (cm) & min & max & MAP \\
\hline 32.8 & 1473 & 1533 & 1508.3 \\
32.9 & 1479 & 1539 & 1513.7 \\
33 & 1485 & 1545 & 1519.1 \\
33.1 & 1491 & 1551 & 1524.5 \\
33.2 & 1497 & 1557 & 1529.9 \\
33.3 & 1498 & 1558 & 1535.3 \\
33.4 & 1504 & 1564 & 1540.8 \\
33.5 & 1510 & 1570 & 1546.2 \\
33.6 & 1516 & 1576 & 1551.6 \\
33.7 & 1522 & 1587 & 1557 \\
33.8 & 1528 & 1593 & 1562.4 \\
33.9 & 1534 & 1599 & 1567.8 \\
34 & 1540 & 1605 & 1573.2 \\
34.1 & 1547 & 1612 & 1578.7 \\
34.2 & 1548 & 1618 & 1584.1 \\
34.3 & 1552 & 1622 & 1589.5 \\
34.4 & 1561 & 1631 & 1594.9 \\
34.5 & 1565 & 1635 & 1600.3 \\
34.6 & 1569 & 1639 & 1605.7 \\
34.7 & 1573 & 1648 & 1611.1 \\
34.8 & 1582 & 1657 & 1616.6 \\
34.9 & 1586 & 1661 & 1622 \\
35 & 1594 & 1669 & 1627.4 \\
35.1 & 1598 & 1673 & 1634.9 \\
35.2 & 1606 & 1681 & 1642.5 \\
35.3 & 1615 & 1685 & 1650 \\
35.4 & 1623 & 1693 & 1657.6 \\
35.5 & 1631 & 1701 & 1665.1 \\
35.6 & 1640 & 1705 & 1672.6 \\
35.7 & 1648 & 1713 & 1680.2 \\
35.8 & 1651 & 1716 & 1687.7 \\
35.9 & 1660 & 1725 & 1695.3 \\
36 & 1668 & 1733 & 1702.8 \\
36.1 & 1676 & 1736 & 1710.4 \\
36.2 & 1685 & 1745 & 1717.9 \\
36.3 & 1693 & 1753 & 1725.4 \\
36.4 & 1697 & 1757 & 1733 \\
36.5 & 1705 & 1765 & 1740.5 \\
36.6 & 1713 & 1773 & 1748.1 \\
36.7 & 1722 & 1782 & 1755.6 \\
36.8 & 1730 & 1790 & 1763.2 \\
& & &
\end{tabular}

\begin{tabular}{rrrr}
\hline Depth (cm) & min & max & MAP \\
\hline 36.9 & 1732 & 1792 & 1770.7 \\
37 & 1739 & 1799 & 1778.2 \\
37.1 & 1746 & 1806 & 1785.8 \\
37.2 & 1753 & 1813 & 1793.3 \\
37.3 & 1760 & 1820 & 1800.9 \\
37.4 & 1767 & 1827 & 1808.4 \\
37.5 & 1774 & 1834 & 1815.9 \\
37.6 & 1781 & 1841 & 1823.5 \\
37.7 & 1793 & 1853 & 1831 \\
37.8 & 1800 & 1860 & 1838.6 \\
37.9 & 1807 & 1867 & 1846.1 \\
38 & 1814 & 1874 & 1853.7 \\
38.1 & 1821 & 1881 & 1861.2 \\
38.2 & 1828 & 1888 & 1868.7 \\
38.3 & 1830 & 1895 & 1876.3 \\
38.4 & 1837 & 1902 & 1883.8 \\
38.5 & 1848 & 1913 & 1891.4 \\
38.6 & 1854 & 1919 & 1898.9 \\
38.7 & 1860 & 1930 & 1906.5 \\
38.8 & 1861 & 1936 & 1914 \\
38.9 & 1877 & 1947 & 1921.5 \\
39 & 1883 & 1953 & 1929.1 \\
39.1 & 1889 & 1964 & 1936.6 \\
39.2 & 1895 & 1970 & 1944.2 \\
39.3 & 1901 & 1976 & 1951.7 \\
39.4 & 1908 & 1983 & 1959.3 \\
39.5 & 1914 & 1994 & 1966.8 \\
39.6 & 1920 & 2000 & 1974.3 \\
39.7 & 1930 & 2010 & 1981.9 \\
39.8 & 1938 & 2018 & 1989.4 \\
39.9 & 1940 & 2025 & 1997 \\
40 & 1948 & 2033 & 2004.5 \\
40.1 & 1957 & 2042 & 2010.9 \\
40.2 & 1966 & 2046 & 2017.4 \\
40.3 & 1976 & 2056 & 2023.8 \\
40.4 & 1985 & 2065 & 2030.2 \\
40.5 & 1989 & 2074 & 2036.7 \\
40.6 & 1998 & 2083 & 2043.1 \\
40.7 & 2008 & 2093 & 2049.5 \\
40.8 & 2012 & 2102 & 2055.9 \\
40.9 & 2021 & 2111 & 2062.4 \\
& & & \\
\hline
\end{tabular}




\begin{tabular}{rrrr}
\hline Depth (cm) & min & max & MAP \\
\hline 41 & 2025 & 2115 & 2068.8 \\
41.1 & 2034 & 2124 & 2075.2 \\
41.2 & 2039 & 2134 & 2081.7 \\
41.3 & 2048 & 2143 & 2088.1 \\
41.4 & 2052 & 2152 & 2094.5 \\
41.5 & 2061 & 2161 & 2101 \\
41.6 & 2065 & 2175 & 2107.4 \\
41.7 & 2075 & 2185 & 2113.8 \\
41.8 & 2079 & 2194 & 2120.2 \\
41.9 & 2088 & 2208 & 2126.7 \\
42 & 2092 & 2217 & 2133.1 \\
42.1 & 2101 & 2231 & 2139.5 \\
42.2 & 2106 & 2241 & 2146 \\
42.3 & 2112 & 2252 & 2152.4 \\
42.4 & 2123 & 2268 & 2158.8 \\
42.5 & 2130 & 2280 & 2165.3 \\
42.6 & 2131 & 2286 & 2171.7 \\
42.7 & 2141 & 2296 & 2178.1 \\
42.8 & 2146 & 2316 & 2184.5 \\
42.9 & 2150 & 2330 & 2191 \\
43 & 2155 & 2340 & 2197.4 \\
43.1 & 2165 & 2340 & 2203.8 \\
43.2 & 2169 & 2364 & 2210.3 \\
43.3 & 2174 & 2374 & 2216.7 \\
43.4 & 2179 & 2369 & 2223.1 \\
43.5 & 2188 & 2383 & 2229.6 \\
43.6 & 2198 & 2393 & 2236 \\
43.7 & 2203 & 2403 & 2242.4 \\
43.8 & 2207 & 2417 & 2248.8 \\
43.9 & 2212 & 2427 & 2255.3 \\
44 & 2217 & 2442 & 2261.7 \\
44.1 & 2211 & 2451 & 2268.1 \\
44.2 & 2216 & 2461 & 2274.6 \\
44.3 & 2221 & 2471 & 2281 \\
44.4 & 2245 & 2480 & 2287.4 \\
44.5 & 2250 & 2495 & 2293.9 \\
44.6 & 2245 & 2505 & 2300.3 \\
44.7 & 2249 & 2519 & 2306.7 \\
44.8 & 2254 & 2529 & 2313.1 \\
44.9 & 2258 & 2538 & 2319.6 \\
45 & 2278 & 2548 & 2326
\end{tabular}

\begin{tabular}{rrrr}
\hline Depth (cm) & min & max & MAP \\
\hline 45.1 & 2275 & 2560 & 2335.6 \\
45.2 & 2287 & 2567 & 2345.2 \\
45.3 & 2300 & 2600 & 2354.8 \\
45.4 & 2307 & 2582 & 2364.4 \\
45.5 & 2319 & 2584 & 2373.9 \\
45.6 & 2326 & 2596 & 2383.5 \\
45.7 & 2343 & 2603 & 2393.1 \\
45.8 & 2355 & 2605 & 2402.7 \\
45.9 & 2363 & 2593 & 2412.3 \\
46 & 2375 & 2600 & 2421.9 \\
46.1 & 2387 & 2627 & 2431.5 \\
46.2 & 2394 & 2614 & 2441.1 \\
46.3 & 2406 & 2641 & 2450.7 \\
46.4 & 2418 & 2643 & 2460.2 \\
46.5 & 2428 & 2658 & 2469.8 \\
46.6 & 2432 & 2672 & 2479.4 \\
46.7 & 2442 & 2672 & 2489 \\
46.8 & 2451 & 2681 & 2498.6 \\
46.9 & 2460 & 2690 & 2508.2 \\
47 & 2469 & 2684 & 2517.8 \\
47.1 & 2473 & 2693 & 2527.4 \\
47.2 & 2482 & 2692 & 2537 \\
47.3 & 2488 & 2703 & 2546.5 \\
47.4 & 2499 & 2714 & 2556.1 \\
47.5 & 2505 & 2720 & 2565.7 \\
47.6 & 2510 & 2730 & 2575.3 \\
47.7 & 2521 & 2741 & 2584.9 \\
47.8 & 2526 & 2751 & 2594.5 \\
47.9 & 2531 & 2761 & 2604.1 \\
48 & 2540 & 2770 & 2613.7 \\
48.1 & 2545 & 2780 & 2623.2 \\
48.2 & 2554 & 2794 & 2632.8 \\
48.3 & 2569 & 2809 & 2642.4 \\
48.4 & 2574 & 2819 & 2652 \\
48.5 & 2578 & 2828 & 2661.6 \\
48.6 & 2583 & 2838 & 2671.2 \\
48.7 & 2592 & 2852 & 2680.8 \\
48.8 & 2597 & 2862 & 2690.4 \\
48.9 & 2606 & 2876 & 2700 \\
49 & 2611 & 2891 & 2709.5 \\
49.1 & 2615 & 2905 & 2719.1 \\
& & & \\
\hline
\end{tabular}




\begin{tabular}{rrrr}
\hline Depth (cm) & min & max & MAP \\
\hline 49.2 & 2625 & 2915 & 2728.7 \\
49.3 & 2629 & 2919 & 2738.3 \\
49.4 & 2634 & 2934 & 2747.9 \\
49.5 & 2643 & 2953 & 2757.5 \\
49.6 & 2648 & 2963 & 2767.1 \\
49.7 & 2652 & 2977 & 2776.7 \\
49.8 & 2657 & 2987 & 2786.3 \\
49.9 & 2661 & 3001 & 2795.8 \\
50 & 2671 & 3016 & 2805.4 \\
50.1 & 2681 & 3021 & 2814.1 \\
50.2 & 2687 & 3022 & 2822.8 \\
50.3 & 2692 & 3022 & 2831.4 \\
50.4 & 2703 & 3038 & 2840.1 \\
50.5 & 2714 & 3039 & 2848.8 \\
50.6 & 2724 & 3044 & 2857.5 \\
50.7 & 2740 & 3055 & 2866.1 \\
50.8 & 2745 & 3060 & 2874.8 \\
50.9 & 2751 & 3066 & 2883.5 \\
51 & 2761 & 3071 & 2892.1 \\
51.1 & 2776 & 3081 & 2900.8 \\
51.2 & 2780 & 3090 & 2909.5 \\
51.3 & 2779 & 3094 & 2918.2 \\
51.4 & 2783 & 3098 & 2926.8 \\
51.5 & 2791 & 3101 & 2935.5 \\
51.6 & 2799 & 3114 & 2944.2 \\
51.7 & 2806 & 3121 & 2952.9 \\
51.8 & 2818 & 3123 & 2961.5 \\
51.9 & 2829 & 3144 & 2970.2 \\
52 & 2830 & 3135 & 2978.9 \\
52.1 & 2837 & 3157 & 2987.5 \\
52.2 & 2852 & 3167 & 2996.2 \\
52.3 & 2853 & 3153 & 3004.9 \\
52.4 & 2863 & 3163 & 3013.6 \\
52.5 & 2868 & 3188 & 3022.2 \\
52.6 & 2879 & 3179 & 3030.9 \\
52.7 & 2889 & 3189 & 3039.6 \\
52.8 & 2895 & 3215 & 3048.2 \\
52.9 & 2900 & 3220 & 3056.9 \\
53 & 2911 & 3231 & 3065.6 \\
53.1 & 2926 & 3236 & 3074.3 \\
53.2 & 2917 & 3242 & 3082.9
\end{tabular}

\begin{tabular}{rrrr}
\hline Depth (cm) & min & max & MAP \\
\hline 53.3 & 2922 & 3247 & 3091.6 \\
53.4 & 2928 & 3253 & 3100.3 \\
53.5 & 2953 & 3263 & 3109 \\
53.6 & 2939 & 3274 & 3117.6 \\
53.7 & 2964 & 3279 & 3126.3 \\
53.8 & 2970 & 3290 & 3135 \\
53.9 & 2975 & 3290 & 3143.6 \\
54 & 2981 & 3301 & 3152.3 \\
54.1 & 2991 & 3311 & 3161 \\
54.2 & 3002 & 3322 & 3169.7 \\
54.3 & 2992 & 3327 & 3178.3 \\
54.4 & 2998 & 3338 & 3187 \\
54.5 & 3003 & 3348 & 3195.7 \\
54.6 & 3009 & 3349 & 3204.3 \\
54.7 & 3019 & 3369 & 3213 \\
54.8 & 3025 & 3370 & 3221.7 \\
54.9 & 3030 & 3385 & 3230.4 \\
55 & 3036 & 3391 & 3239 \\
55.1 & 3049 & 3399 & 3246.2 \\
55.2 & 3062 & 3402 & 3253.4 \\
55.3 & 3075 & 3415 & 3260.6 \\
55.4 & 3089 & 3424 & 3267.8 \\
55.5 & 3097 & 3427 & 3275 \\
55.6 & 3110 & 3435 & 3282.2 \\
55.7 & 3123 & 3443 & 3289.4 \\
55.8 & 3127 & 3452 & 3296.6 \\
55.9 & 3140 & 3445 & 3303.8 \\
56 & 3153 & 3463 & 3310.9 \\
56.1 & 3166 & 3471 & 3318.1 \\
56.2 & 3175 & 3465 & 3325.3 \\
56.3 & 3188 & 3478 & 3332.5 \\
56.4 & 3201 & 3486 & 3339.7 \\
56.5 & 3214 & 3499 & 3346.9 \\
56.6 & 3228 & 3508 & 3354.1 \\
56.7 & 3231 & 3511 & 3361.3 \\
56.8 & 3239 & 3514 & 3368.5 \\
56.9 & 3252 & 3517 & 3375.7 \\
57 & 3265 & 3530 & 3382.9 \\
57.1 & 3279 & 3534 & 3390 \\
57.2 & 3287 & 3542 & 3397.2 \\
57.3 & 3295 & 3550 & 3404.4
\end{tabular}




\begin{tabular}{|c|c|c|c|}
\hline (cm) & $\min$ & $\max$ & MAP \\
\hline 57.4 & 3303 & 3558 & 3411.6 \\
\hline 57.5 & 3317 & 3567 & 3418.8 \\
\hline 57.6 & 3323 & 3573 & 3426 \\
\hline 57.7 & 3339 & 3579 & 3433.2 \\
\hline 57.8 & 3350 & 3585 & 3440.4 \\
\hline 57.9 & 3363 & 3593 & 3447.6 \\
\hline 58 & 3370 & 3600 & 3454.8 \\
\hline 58.1 & 3381 & 3606 & 3462 \\
\hline 58.2 & 3392 & 3622 & 3469.1 \\
\hline 58.3 & 3403 & 3628 & 3476.3 \\
\hline 58.4 & 3409 & 3639 & 3483.5 \\
\hline 58.5 & 3420 & 3645 & 3490.7 \\
\hline 58.6 & 3426 & 3656 & 3497.9 \\
\hline 58.7 & 3437 & 3667 & 3505.1 \\
\hline 58.8 & 3448 & 3673 & 3512.3 \\
\hline 58.9 & 3459 & 3684 & 3519.5 \\
\hline 59 & 3465 & 3690 & 3526.7 \\
\hline 59.1 & 3476 & 3701 & \\
\hline 59.2 & 3482 & 3707 & 3541.1 \\
\hline 59.3 & 3498 & 3718 & 3548.2 \\
\hline 59.4 & 3499 & 3729 & 3555.4 \\
\hline & 3505 & & \\
\hline 59.6 & 3516 & 3746 & 3569.8 \\
\hline 59.7 & 3522 & 3752 & 3577 \\
\hline 59.8 & 3533 & 3763 & 3584.2 \\
\hline 59.9 & 3539 & 3769 & 3591.4 \\
\hline 60 & 3550 & 3780 & 3598.6 \\
\hline 60.1 & 3561 & 3791 & 3613.2 \\
\hline 60.2 & 3577 & 3802 & 3627.9 \\
\hline 60.3 & 3584 & 3809 & 3642.6 \\
\hline 60.4 & 3595 & 3825 & 3657.3 \\
\hline 60.5 & 3606 & 3836 & 3671.9 \\
\hline 60.6 & 3617 & 3852 & 3686.6 \\
\hline 60.7 & 3623 & 3858 & 3701.3 \\
\hline 60.8 & 3638 & 3878 & 3715.9 \\
\hline 60.9 & 3643 & 3893 & 3730.6 \\
\hline 61 & 3656 & 3911 & 3745.3 \\
\hline 61.1 & 3664 & 3924 & 3759.9 \\
\hline 61.2 & 3673 & 3938 & 3774.6 \\
\hline 61.3 & 3681 & 3951 & 3789.3 \\
\hline 61.4 & 3689 & 3969 & 3803.9 \\
\hline epth (cm) & $\min$ & ma & MAP \\
\hline
\end{tabular}

\begin{tabular}{|c|c|c|c|}
\hline Depth (cm) & $\min$ & $\max$ & MAP \\
\hline 61.5 & 3702 & 3977 & 3818.6 \\
\hline 61.6 & 3715 & 3980 & 3833.3 \\
\hline 61.7 & 3723 & 3998 & 3847.9 \\
\hline 61.8 & 3732 & 4027 & 3862.6 \\
\hline 61.9 & 3745 & 4030 & 3877.3 \\
\hline 62 & 3753 & 4043 & 3892 \\
\hline 62.1 & 3766 & 4081 & 3906.6 \\
\hline 62.2 & 3774 & 4089 & 3921.3 \\
\hline 62.3 & 3782 & 4102 & 3936 \\
\hline 62.4 & 3789 & 4114 & 3950.6 \\
\hline 62.5 & 3800 & 4125 & 3965.3 \\
\hline 62.6 & 3806 & 4126 & 3980 \\
\hline 62.7 & 3811 & 4136 & 3994.6 \\
\hline 62.8 & 3821 & 4151 & 4009.3 \\
\hline 62.9 & 3826 & 4166 & 4024 \\
\hline 63 & 3832 & 4222 & 4038.6 \\
\hline 63.1 & 3842 & 4197 & 4053.3 \\
\hline 63.2 & 3847 & 4217 & 4068 \\
\hline 63.3 & 3862 & 4237 & 4082.6 \\
\hline 63.4 & 3867 & 4272 & 4097.3 \\
\hline 63.5 & 3878 & 4273 & 4112 \\
\hline 63.6 & 3883 & 4283 & 4126.6 \\
\hline 63.7 & 3893 & 4303 & 4141.3 \\
\hline 63.8 & 3903 & 4318 & 4156 \\
\hline 63.9 & 3894 & 4334 & 4170.7 \\
\hline 64 & 3899 & 4344 & 4185.3 \\
\hline 64.1 & 3909 & 4359 & 4200 \\
\hline 64.2 & 3914 & 4384 & 4214.7 \\
\hline 64.3 & 3919 & 4389 & 4229.3 \\
\hline 64.4 & 3925 & 4405 & 4244 \\
\hline 64.5 & 3930 & 4420 & 4258.7 \\
\hline 64.6 & 3940 & 4435 & 4273.3 \\
\hline 64.7 & 3980 & 4450 & 4288 \\
\hline 64.8 & 3991 & 4471 & 4302.7 \\
\hline 64.9 & 3996 & 4486 & 4317.3 \\
\hline 65 & 4001 & 4496 & 4332 \\
\hline 65.1 & 4013 & 4508 & 4345.5 \\
\hline 65.2 & 4029 & 4544 & 4359 \\
\hline 65.3 & 4036 & 4556 & 4372.5 \\
\hline 65.4 & 4052 & 4562 & 4386 \\
\hline 65.5 & 4064 & 4569 & 4399.4 \\
\hline Depth (cm) & $\min$ & $\max$ & MAP \\
\hline
\end{tabular}




\begin{tabular}{rrrr}
\hline 65.6 & 4071 & 4576 & 4412.9 \\
65.7 & 4077 & 4582 & 4426.4 \\
65.8 & 4094 & 4594 & 4439.9 \\
65.9 & 4095 & 4605 & 4453.4 \\
66 & 4132 & 4617 & 4466.9 \\
66.1 & 4144 & 4624 & 4480.4 \\
66.2 & 4155 & 4635 & 4493.9 \\
66.3 & 4172 & 4647 & 4507.4 \\
66.4 & 4183 & 4658 & 4520.8 \\
66.5 & 4185 & 4670 & 4534.3 \\
66.6 & 4192 & 4677 & 4547.8 \\
66.7 & 4208 & 4683 & 4561.3 \\
66.8 & 4220 & 4695 & 4574.8 \\
66.9 & 4231 & 4716 & 4588.3 \\
67 & 4258 & 4723 & 4601.8 \\
67.1 & 4240 & 4735 & 4615.3 \\
67.2 & 4271 & 4741 & 4628.7 \\
67.3 & 4278 & 4753 & 4642.2 \\
67.4 & 4289 & 4764 & 4655.7 \\
67.5 & 4296 & 4781 & 4669.2 \\
67.6 & 4308 & 4788 & 4682.7 \\
67.7 & 4324 & 4794 & 4696.2 \\
67.8 & 4331 & 4801 & 4709.7 \\
67.9 & 4338 & 4813 & 4723.2 \\
68 & 4349 & 4854 & 4736.6 \\
68.1 & 4361 & 4846 & 4750.1 \\
68.2 & 4372 & 4862 & 4763.6 \\
68.3 & 4389 & 4874 & 4777.1 \\
68.4 & 4396 & 4896 & 4790.6 \\
68.5 & 4407 & 4907 & 4804.1 \\
68.6 & 4419 & 4924 & 4817.6 \\
68.7 & 4435 & 4955 & 4831.1 \\
68.8 & 4442 & 4947 & 4844.6 \\
68.9 & 4454 & 4964 & 4858 \\
69 & 4461 & 4971 & 4871.5 \\
69.1 & 4467 & 4987 & 4885 \\
69.2 & 4479 & 5004 & 4898.5 \\
69.3 & 4486 & 5006 & 4912 \\
69.4 & 4502 & 5012 & 4925.5 \\
69.5 & 4514 & 5019 & 4939 \\
69.6 & 4526 & 5036 & 4952.5
\end{tabular}

\begin{tabular}{|c|c|c|c|}
\hline 69.7 & 4542 & 5052 & 4965.9 \\
\hline 69.8 & 4554 & 5069 & 4979.4 \\
\hline 69.9 & 4556 & 5076 & 4992.9 \\
\hline 70 & 4567 & 5092 & 5006.4 \\
\hline 70.1 & 4576 & 5101 & 5016.3 \\
\hline 70.2 & 4589 & 5114 & 5026.2 \\
\hline 70.3 & 4607 & 5152 & 5036 \\
\hline 70.4 & 4615 & 5130 & 5045.9 \\
\hline 70.5 & 4614 & 5164 & 5055.8 \\
\hline 70.6 & 4607 & 5147 & 5065.7 \\
\hline 70.7 & 4645 & 5160 & 5075.5 \\
\hline 70.8 & 4618 & 5163 & 5085.4 \\
\hline 70.9 & 4666 & 5201 & 5095.3 \\
\hline 71 & 4680 & 5205 & 5105.2 \\
\hline 71.1 & 4688 & 5213 & 5115 \\
\hline 71.2 & 4696 & 5211 & 5124.9 \\
\hline 71.3 & 4704 & 5234 & 5134.8 \\
\hline 71.4 & 4723 & 5238 & 5144.7 \\
\hline 71.5 & 4731 & 5246 & 5154.5 \\
\hline 71.6 & 4739 & 5254 & 5164.4 \\
\hline 71.7 & 4702 & 5262 & 5174.3 \\
\hline 71.8 & 4710 & 5270 & 5184.2 \\
\hline 71.9 & 4714 & 5284 & 5194 \\
\hline 72 & 4717 & 5292 & 5203.9 \\
\hline 72.1 & 4730 & 5300 & 5213.8 \\
\hline 72.2 & 4743 & 5308 & 5223.7 \\
\hline 72.3 & 4747 & 5317 & 5233.5 \\
\hline 72.4 & 4760 & 5325 & 5243.4 \\
\hline 72.5 & 4773 & 5333 & 5253.3 \\
\hline 72.6 & 4781 & 5346 & 5263.2 \\
\hline 72.7 & 4845 & 5355 & 5273 \\
\hline 72.8 & 4803 & 5363 & 5282.9 \\
\hline 72.9 & 4816 & 5371 & 5292.8 \\
\hline 73 & 4824 & 5379 & 5302.7 \\
\hline 73.1 & 4827 & 5387 & 5312.5 \\
\hline 73.2 & 4836 & 5396 & 5322.4 \\
\hline 73.3 & 4884 & 5409 & 5332.3 \\
\hline 73.4 & 4887 & 5422 & 5342.2 \\
\hline 73.5 & 4890 & 5440 & 5352 \\
\hline 73.6 & 4904 & 5454 & 5361.9 \\
\hline 73.7 & 4907 & 5462 & 5371.8 \\
\hline
\end{tabular}




\begin{tabular}{rlll}
\hline Depth (cm) & min & max & MAP \\
\hline 73.8 & 4885 & 5480 & 5381.7 \\
73.9 & 4923 & 5488 & 5391.5 \\
74 & 4901 & 5501 & 5401.4 \\
74.1 & 4965 & 5510 & 5411.3 \\
74.2 & 4973 & 5523 & 5421.2 \\
74.3 & 4976 & 5531 & 5431 \\
74.4 & 4984 & 5539 & 5440.9 \\
74.5 & 4993 & 5553 & 5450.8 \\
74.6 & 5001 & 5566 & 5460.7 \\
74.7 & 5009 & 5579 & 5470.5 \\
74.8 & 5017 & 5587 & 5480.4 \\
74.9 & 5030 & 5600 & 5490.3 \\
75 & 5034 & 5614 & 5500.2 \\
75.1 & 5049 & 5619 & 5506.8 \\
75.2 & 5055 & 5625 & 5513.5 \\
75.3 & 5080 & 5630 & 5520.2 \\
75.4 & 5096 & 5636 & 5526.8 \\
75.5 & 5081 & 5646 & 5533.5 \\
75.6 & 5092 & 5652 & 5540.2 \\
75.7 & 5107 & 5657 & 5546.8 \\
75.8 & 5163 & 5668 & 5553.5 \\
75.9 & 5173 & 5673 & 5560.2 \\
76 & 5179 & 5684 & 5566.8 \\
76.1 & 5189 & 5684 & 5573.5 \\
76.2 & 5200 & 5695 & 5580.2 \\
76.3 & 5205 & 5700 & 5586.8 \\
76.4 & 5221 & 5706 & 5593.5 \\
76.5 & 5236 & 5711 & 5600.2 \\
76.6 & 5241 & 5716 & 5606.8 \\
76.7 & 5256 & 5726 & 5613.5 \\
76.8 & 5267 & 5732 & 5620.2 \\
76.9 & 5207 & 5742 & 5626.8 \\
77 & 5287 & 5752 & 5633.5 \\
77.1 & 5298 & 5753 & 5640.2 \\
77.2 & 5313 & 5763 & 5646.8 \\
77.3 & 5328 & 5773 & 5653.5 \\
77.4 & 5339 & 5784 & 5660.2 \\
77.5 & 5349 & 5794 & 5666.8 \\
77.6 & 5359 & 5799 & 5673.5 \\
77.7 & 5369 & 5804 & 5680.2 \\
77.8 & 5370 & 5810 & 5686.8
\end{tabular}

\begin{tabular}{rrrr}
\hline Depth (cm) & min & max & MAP \\
\hline 77.9 & 5320 & 5815 & 5693.5 \\
78 & 5395 & 5825 & 5700.2 \\
78.1 & 5406 & 5836 & 5706.8 \\
78.2 & 5396 & 5841 & 5713.5 \\
78.3 & 5401 & 5846 & 5720.2 \\
78.4 & 5412 & 5852 & 5726.9 \\
78.5 & 5422 & 5867 & 5733.5 \\
78.6 & 5432 & 5867 & 5740.2 \\
78.7 & 5443 & 5873 & 5746.9 \\
78.8 & 5453 & 5883 & 5753.5 \\
78.9 & 5468 & 5893 & 5760.2 \\
79 & 5478 & 5903 & 5766.9 \\
79.1 & 5479 & 5914 & 5773.5 \\
79.2 & 5489 & 5904 & 5780.2 \\
79.3 & 5494 & 5914 & 5786.9 \\
79.4 & 5500 & 5925 & 5793.5 \\
79.5 & 5515 & 5930 & 5800.2 \\
79.6 & 5520 & 5940 & 5806.9 \\
79.7 & 5531 & 5951 & 5813.5 \\
79.8 & 5541 & 5961 & 5820.2 \\
79.9 & 5551 & 5966 & 5826.9 \\
80 & 5558 & 5973 & 5833.5 \\
80.1 & 5548 & 5978 & 5840.2 \\
80.2 & 5562 & 5982 & 5846.9 \\
80.3 & 5591 & 5996 & 5853.5 \\
80.4 & 5605 & 6005 & 5860.2 \\
80.5 & 5608 & 6013 & 5866.9 \\
80.6 & 5606 & 6021 & 5873.6 \\
80.7 & 5614 & 6009 & 5880.2 \\
80.8 & 5638 & 6018 & 5886.9 \\
80.9 & 5641 & 6021 & 5893.6 \\
81 & 5654 & 6029 & 5900.2 \\
81.1 & 5667 & 6037 & 5906.9 \\
81.2 & 5676 & 6051 & 5913.6 \\
81.3 & 5684 & 6059 & 5920.2 \\
81.4 & 5697 & 6077 & 5926.9 \\
81.5 & 5710 & 6080 & 5933.6 \\
81.6 & 5729 & 6084 & 5940.3 \\
81.7 & 5742 & 6092 & 5946.9 \\
81.8 & 5735 & 6100 & 5953.6 \\
81.9 & 5740 & 6100 & 5960.3
\end{tabular}




\begin{tabular}{rrrr}
\hline Depth (cm) & min & max & MAP \\
\hline 82 & 5749 & 6104 & 5966.9 \\
82.1 & 5758 & 6108 & 5973.6 \\
82.2 & 5767 & 6117 & 5980.3 \\
82.3 & 5776 & 6126 & 5986.9 \\
82.4 & 5805 & 6135 & 5993.6 \\
82.5 & 5814 & 6144 & 6000.3 \\
82.6 & 5824 & 6149 & 6007 \\
82.7 & 5833 & 6153 & 6013.6 \\
82.8 & 5847 & 6162 & 6020.3 \\
82.9 & 5856 & 6171 & 6027 \\
83 & 5815 & 6170 & 6033.6 \\
83.1 & 5824 & 6184 & 6040.3 \\
83.2 & 5869 & 6194 & 6047 \\
83.3 & 5843 & 6198 & 6053.6 \\
83.4 & 5897 & 6207 & 6060.3 \\
83.5 & 5901 & 6211 & 6067 \\
83.6 & 5880 & 6220 & 6073.7 \\
83.7 & 5909 & 6229 & 6080.3 \\
83.8 & 5899 & 6229 & 6087 \\
83.9 & 5923 & 6243 & 6093.7 \\
84 & 5917 & 6247 & 6100.3 \\
84.1 & 5936 & 6256 & 6107 \\
84.2 & 5950 & 6265 & 6113.7 \\
84.3 & 5959 & 6274 & 6120.4 \\
84.4 & 5969 & 6279 & 6127 \\
84.5 & 5978 & 6278 & 6133.7 \\
84.6 & 5982 & 6287 & 6140.4 \\
84.7 & 5996 & 6296 & 6147 \\
84.8 & 6004 & 6304 & 6153.7 \\
84.9 & 6010 & 6310 & 6160.4 \\
85 & 6021 & 6321 & 6167 \\
85.1 & 6034 & 6329 & 6176.1 \\
85.2 & 6052 & 6337 & 6185.2 \\
85.3 & 6057 & 6342 & 6194.4 \\
85.4 & 6067 & 6352 & 6203.5 \\
85.5 & 6077 & 6357 & 6212.6 \\
85.6 & 6091 & 6361 & 6221.7 \\
85.7 & 6101 & 6366 & 6230.8 \\
85.8 & 6106 & 6371 & 6239.9 \\
85.9 & 6110 & 6375 & 6249 \\
86 & 6115 & 6385 & 6258.1
\end{tabular}

\begin{tabular}{rrrr}
\hline Depth (cm) & min & max & MAP \\
\hline 86.1 & 6144 & 6389 & 6267.2 \\
86.2 & 6139 & 6394 & 6276.3 \\
86.3 & 6159 & 6399 & 6285.4 \\
86.4 & 6168 & 6408 & 6294.5 \\
86.5 & 6178 & 6413 & 6303.6 \\
86.6 & 6183 & 6418 & 6312.7 \\
86.7 & 6192 & 6427 & 6321.8 \\
86.8 & 6182 & 6432 & 6330.9 \\
86.9 & 6216 & 6436 & 6340 \\
87 & 6226 & 6441 & 6349.1 \\
87.1 & 6236 & 6446 & 6358.2 \\
87.2 & 6245 & 6455 & 6367.3 \\
87.3 & 6260 & 6465 & 6376.4 \\
87.4 & 6285 & 6470 & 6385.5 \\
87.5 & 6274 & 6474 & 6394.6 \\
87.6 & 6284 & 6484 & 6403.7 \\
87.7 & 6294 & 6494 & 6412.8 \\
87.8 & 6308 & 6498 & 6421.9 \\
87.9 & 6318 & 6503 & 6431 \\
88 & 6317 & 6512 & 6440.1 \\
88.1 & 6327 & 6517 & 6449.2 \\
88.2 & 6337 & 6527 & 6458.3 \\
88.3 & 6346 & 6531 & 6467.4 \\
88.4 & 6356 & 6541 & 6476.5 \\
88.5 & 6371 & 6546 & 6485.6 \\
88.6 & 6375 & 6550 & 6494.7 \\
88.7 & 6385 & 6560 & 6503.8 \\
88.8 & 6395 & 6565 & 6512.9 \\
88.9 & 6399 & 6574 & 6522.1 \\
89 & 6414 & 6589 & 6531.2 \\
89.1 & 6423 & 6593 & 6540.3 \\
89.2 & 6433 & 6608 & 6549.4 \\
89.3 & 6438 & 6613 & 6558.5 \\
89.4 & 6447 & 6622 & 6567.6 \\
89.5 & 6452 & 6632 & 6576.7 \\
89.6 & 6457 & 6642 & 6585.8 \\
89.7 & 6466 & 6651 & 6594.9 \\
89.8 & 6471 & 6661 & 6604 \\
89.9 & 6480 & 6670 & 6613.1 \\
90 & 6505 & 6685 & 6622.2 \\
90.1 & 6497 & 6692 & 6629.8 \\
& & & \\
\hline
\end{tabular}




\begin{tabular}{rrrr}
\hline Depth (cm) & min & max & MAP \\
\hline 90.2 & 6503 & 6698 & 6637.4 \\
90.3 & 6515 & 6705 & 6645 \\
90.4 & 6526 & 6711 & 6652.7 \\
90.5 & 6543 & 6718 & 6660.3 \\
90.6 & 6554 & 6729 & 6667.9 \\
90.7 & 6576 & 6736 & 6675.5 \\
90.8 & 6583 & 6743 & 6683.1 \\
90.9 & 6589 & 6749 & 6690.8 \\
91 & 6596 & 6756 & 6698.4 \\
91.1 & 6606 & 6761 & 6706 \\
91.2 & 6614 & 6769 & 6713.6 \\
91.3 & 6622 & 6772 & 6721.3 \\
91.4 & 6630 & 6780 & 6728.9 \\
91.5 & 6637 & 6787 & 6736.5 \\
91.6 & 6640 & 6795 & 6744.1 \\
91.7 & 6648 & 6803 & 6751.7 \\
91.8 & 6661 & 6811 & 6759.4 \\
91.9 & 6659 & 6814 & 6767 \\
92 & 6671 & 6826 & 6774.6 \\
92.1 & 6679 & 6834 & 6782.2 \\
92.2 & 6687 & 6842 & 6789.8 \\
92.3 & 6695 & 6855 & 6797.5 \\
92.4 & 6707 & 6862 & 6805.1 \\
92.5 & 6715 & 6870 & 6812.7 \\
92.6 & 6723 & 6878 & 6820.3 \\
92.7 & 6731 & 6886 & 6827.9 \\
92.8 & 6739 & 6894 & 6835.6 \\
92.9 & 6746 & 6906 & 6843.2 \\
93 & 6754 & 6914 & 6850.8 \\
93.1 & 6757 & 6922 & 6858.4 \\
93.2 & 6770 & 6935 & 6866 \\
93.3 & 6777 & 6942 & 6873.7 \\
93.4 & 6780 & 6950 & 6881.3 \\
93.5 & 6788 & 6963 & 6888.9 \\
93.6 & 6797 & 6972 & 6896.5 \\
93.7 & 6802 & 6982 & 6904.1 \\
93.8 & 6806 & 6991 & 6911.8 \\
93.9 & 6811 & 7001 & 6919.4 \\
94.1 & 6815 & 7010 & 6927 \\
94.2 & 6829 & 7015 & 6934.6 \\
& & & 6942.3
\end{tabular}

\begin{tabular}{rrrr}
\hline Depth (cm) & min & max & MAP \\
\hline 94.3 & 6834 & 7034 & 6949.9 \\
94.4 & 6838 & 7043 & 6957.5 \\
94.5 & 6848 & 7058 & 6965.1 \\
94.6 & 6847 & 7062 & 6972.7 \\
94.7 & 6857 & 7077 & 6980.4 \\
94.8 & 6861 & 7086 & 6988 \\
94.9 & 6871 & 7096 & 6995.6 \\
95 & 6875 & 7105 & 7003.2 \\
95.1 & 6878 & 7108 & 7010.2 \\
95.2 & 6885 & 7115 & 7017.2 \\
95.3 & 6893 & 7123 & 7024.2 \\
95.4 & 6901 & 7131 & 7031.2 \\
95.5 & 6913 & 7138 & 7038.2 \\
95.6 & 6916 & 7146 & 7045.2 \\
95.7 & 6923 & 7153 & 7052.1 \\
95.8 & 6931 & 7161 & 7059.1 \\
95.9 & 6929 & 7169 & 7066.1 \\
96 & 6941 & 7176 & 7073.1 \\
96.1 & 6944 & 7179 & 7080.1 \\
96.2 & 6956 & 7191 & 7087.1 \\
96.3 & 6959 & 7194 & 7094.1 \\
96.4 & 6967 & 7202 & 7101.1 \\
96.5 & 6974 & 7214 & 7108.1 \\
96.6 & 6967 & 7217 & 7115 \\
96.7 & 6989 & 7229 & 7122 \\
96.8 & 6992 & 7232 & 7129 \\
96.9 & 6990 & 7240 & 7136 \\
97 & 6997 & 7247 & 7143 \\
97.1 & 7005 & 7255 & 7150 \\
97.2 & 7012 & 7262 & 7157 \\
97.3 & 7020 & 7275 & 7164 \\
97.4 & 7028 & 7283 & 7171 \\
97.5 & 7035 & 7290 & 7177.9 \\
97.6 & 7038 & 7293 & 7184.9 \\
97.7 & 7045 & 7305 & 7191.9 \\
97.8 & 7053 & 7313 & 7198.9 \\
97.9 & 7058 & 7323 & 7205.9 \\
98.1 & 7064 & 7329 & 7212.9 \\
98.2 & 7070 & 7340 & 7219.9 \\
98.3 & 7082 & 7357 & 7233.9
\end{tabular}




\begin{tabular}{rrrr}
\hline Depth (cm) & min & max & MAP \\
\hline 98.4 & 7083 & 7363 & 7240.8 \\
98.5 & 7093 & 7388 & 7247.8 \\
98.6 & 7099 & 7384 & 7254.8 \\
98.7 & 7100 & 7390 & 7261.8 \\
98.8 & 7106 & 7401 & 7268.8 \\
98.9 & 7110 & 7410 & 7275.8 \\
99 & 7119 & 7424 & 7282.8 \\
99.1 & 7123 & 7433 & 7289.8 \\
99.2 & 7122 & 7442 & 7296.8 \\
99.3 & 7136 & 7451 & 7303.7 \\
99.4 & 7140 & 7460 & 7310.7 \\
99.5 & 7149 & 7474 & 7317.7 \\
99.6 & 7153 & 7483 & 7324.7 \\
99.7 & 7157 & 7492 & 7331.7 \\
99.8 & 7161 & 7501 & 7338.7 \\
99.9 & 7165 & 7510 & 7345.7 \\
100 & 7173 & 7528 & 7352.7 \\
100.1 & 7181 & 7531 & 7359.5 \\
100.2 & 7188 & 7538 & 7366.4 \\
100.3 & 7195 & 7545 & 7373.3 \\
100.4 & 7203 & 7548 & 7380.1 \\
100.5 & 7210 & 7550 & 7387 \\
100.6 & 7217 & 7562 & 7393.9 \\
100.7 & 7224 & 7569 & 7400.8 \\
100.8 & 7232 & 7572 & 7407.6 \\
100.9 & 7244 & 7594 & 7414.5 \\
101 & 7251 & 7606 & 7421.4 \\
101.1 & 7258 & 7613 & 7428.2 \\
101.2 & 7246 & 7621 & 7435.1 \\
101.3 & 7273 & 7628 & 7442 \\
101.4 & 7280 & 7635 & 7448.8 \\
101.5 & 7267 & 7637 & 7455.7 \\
101.6 & 7275 & 7645 & 7462.6 \\
101.7 & 7282 & 7637 & 7469.4 \\
101.8 & 7304 & 7654 & 7476.3 \\
101.9 & 7301 & 7656 & 7483.2 \\
102 & 7304 & 7649 & 7490 \\
102.1 & 7316 & 7661 & 7496.9 \\
102.2 & 7318 & 7663 & 7503.8 \\
102.3 & 7325 & 7670 & 7510.7 \\
102.4 & 7328 & 7683 & 7517.5
\end{tabular}

\begin{tabular}{rrrr}
\hline Depth (cm) & min & max & MAP \\
\hline 102.5 & 7340 & 7685 & 7524.4 \\
102.6 & 7347 & 7692 & 7531.3 \\
102.7 & 7354 & 7704 & 7538.1 \\
102.8 & 7347 & 7712 & 7545 \\
102.9 & 7356 & 7726 & 7551.9 \\
103 & 7366 & 7731 & 7558.7 \\
103.1 & 7360 & 7720 & 7565.6 \\
103.2 & 7360 & 7730 & 7572.5 \\
103.3 & 7389 & 7759 & 7579.3 \\
103.4 & 7384 & 7769 & 7586.2 \\
103.5 & 7389 & 7774 & 7593.1 \\
103.6 & 7388 & 7783 & 7600 \\
103.7 & 7398 & 7793 & 7606.8 \\
103.8 & 7407 & 7802 & 7613.7 \\
103.9 & 7412 & 7812 & 7620.6 \\
104 & 7416 & 7816 & 7627.4 \\
104.1 & 7421 & 7821 & 7634.3 \\
104.2 & 7425 & 7830 & 7641.2 \\
104.3 & 7435 & 7840 & 7648 \\
104.4 & 7439 & 7844 & 7654.9 \\
104.5 & 7444 & 7854 & 7661.8 \\
104.6 & 7448 & 7863 & 7668.6 \\
104.7 & 7458 & 7868 & 7675.5 \\
104.8 & 7463 & 7878 & 7682.4 \\
104.9 & 7472 & 7887 & 7689.2 \\
105 & 7472 & 7887 & 7696.1 \\
105.1 & 7480 & 7895 & 7700.8 \\
105.2 & 7488 & 7898 & 7705.5 \\
105.3 & 7496 & 7906 & 7710.2 \\
105.4 & 7505 & 7910 & 7714.9 \\
105.5 & 7513 & 7913 & 7719.6 \\
105.6 & 7521 & 7921 & 7724.4 \\
105.7 & 7525 & 7920 & 7729.1 \\
105.8 & 7533 & 7928 & 7733.8 \\
105.9 & 7541 & 7931 & 7738.5 \\
106 & 7549 & 7934 & 7743.2 \\
106.1 & 7538 & 7943 & 7747.9 \\
106.2 & 7546 & 7941 & 7752.6 \\
106.3 & 7554 & 7954 & 7757.3 \\
106.4 & 7562 & 7952 & 7762 \\
106.5 & 7571 & 7956 & 7766.7 \\
& & &
\end{tabular}




\begin{tabular}{rrrr}
\hline Depth (cm) & min & max & MAP \\
\hline 106.6 & 7579 & 7969 & 7771.4 \\
106.7 & 7582 & 7967 & 7776.1 \\
106.8 & 7592 & 7977 & 7780.8 \\
106.9 & 7602 & 7982 & 7785.5 \\
107 & 7607 & 7977 & 7790.2 \\
107.1 & 7612 & 7997 & 7794.9 \\
107.2 & 7617 & 8007 & 7799.7 \\
107.3 & 7626 & 8016 & 7804.4 \\
107.4 & 7636 & 8016 & 7809.1 \\
107.5 & 7646 & 8021 & 7813.8 \\
107.6 & 7651 & 8031 & 7818.5 \\
107.7 & 7655 & 8030 & 7823.2 \\
107.8 & 7660 & 8035 & 7827.9 \\
107.9 & 7670 & 8045 & 7832.6 \\
108 & 7675 & 8050 & 7837.3 \\
108.1 & 7685 & 8080 & 7842 \\
108.2 & 7689 & 8059 & 7846.7 \\
108.3 & 7694 & 8094 & 7851.4 \\
108.4 & 7699 & 8104 & 7856.1 \\
108.5 & 7713 & 8108 & 7860.8 \\
108.6 & 7717 & 8117 & 7865.5 \\
108.7 & 7721 & 8121 & 7870.2 \\
108.8 & 7725 & 8130 & 7875 \\
108.9 & 7728 & 8138 & 7879.7 \\
109 & 7732 & 8142 & 7884.4 \\
109.1 & 7741 & 8151 & 7889.1 \\
109.2 & 7745 & 8125 & 7893.8 \\
109.3 & 7749 & 8164 & 7898.5 \\
109.4 & 7753 & 8168 & 7903.2 \\
109.5 & 7752 & 8172 & 7907.9 \\
109.6 & 7761 & 8151 & 7912.6 \\
109.7 & 7765 & 8150 & 7917.3 \\
109.8 & 7774 & 8159 & 7922 \\
109.9 & 7777 & 8167 & 7926.7 \\
110 & 7786 & 8206 & 7931.4 \\
110.1 & 7790 & 8180 & 7936.5 \\
110.2 & 7803 & 8203 & 7941.6 \\
110.3 & 7816 & 8211 & 7946.7 \\
110.4 & 7815 & 8220 & 7951.8 \\
110.5 & 7828 & 8223 & 7956.9 \\
110.6 & 7827 & 8232 & 7962 \\
& & &
\end{tabular}

\begin{tabular}{rrrr}
\hline Depth (cm) & min & max & MAP \\
\hline 110.7 & 7840 & 8235 & 7967.1 \\
110.8 & 7843 & 8243 & 7972.2 \\
110.9 & 7852 & 8247 & 7977.3 \\
111 & 7860 & 8245 & 7982.3 \\
111.1 & 7864 & 8229 & 7987.4 \\
111.2 & 7877 & 8252 & 7992.5 \\
111.3 & 7885 & 8245 & 7997.6 \\
111.4 & 7899 & 8259 & 8002.7 \\
111.5 & 7902 & 8257 & 8007.8 \\
111.6 & 7916 & 8271 & 8012.9 \\
111.7 & 7924 & 8274 & 8018 \\
111.8 & 7932 & 8282 & 8023.1 \\
111.9 & 7941 & 8296 & 8028.2 \\
112 & 7949 & 8304 & 8033.3 \\
112.1 & 7953 & 8298 & 8038.3 \\
112.2 & 7956 & 8301 & 8043.4 \\
112.3 & 7964 & 8309 & 8048.5 \\
112.4 & 7968 & 8313 & 8053.6 \\
112.5 & 7976 & 8321 & 8058.7 \\
112.6 & 7984 & 8329 & 8063.8 \\
112.7 & 7993 & 8333 & 8068.9 \\
112.8 & 8001 & 8341 & 8074 \\
112.9 & 8010 & 8350 & 8079.1 \\
113 & 8013 & 8353 & 8084.2 \\
113.1 & 8021 & 8361 & 8089.3 \\
113.2 & 8029 & 8369 & 8094.3 \\
113.3 & 8035 & 8375 & 8099.4 \\
113.4 & 8045 & 8385 & 8104.5 \\
113.5 & 8051 & 8391 & 8109.6 \\
113.6 & 8057 & 8397 & 8114.7 \\
113.7 & 8063 & 8413 & 8119.8 \\
113.8 & 8074 & 8414 & 8124.9 \\
113.9 & 8079 & 8419 & 8130 \\
114 & 8080 & 8425 & 8135.1 \\
114.1 & 8081 & 8426 & 8140.2 \\
114.2 & 8092 & 8437 & 8145.3 \\
114.3 & 8098 & 8438 & 8150.3 \\
114.4 & 8103 & 8448 & 8155.4 \\
114.5 & 8109 & 8469 & 8160.5 \\
114.6 & 8115 & 8475 & 8165.6 \\
114.7 & 8121 & 8471 & 8170.7 \\
& & & \\
\hline
\end{tabular}




\begin{tabular}{rrrr}
\hline Depth (cm) & \multicolumn{1}{c}{ min } & \multicolumn{1}{c}{ max } & \multicolumn{1}{l}{ MAP } \\
\hline 114.8 & 8132 & 8482 & 8175.8 \\
114.9 & 8133 & 8488 & 8180.9 \\
115 & 8143 & 8493 & 8186
\end{tabular}

